
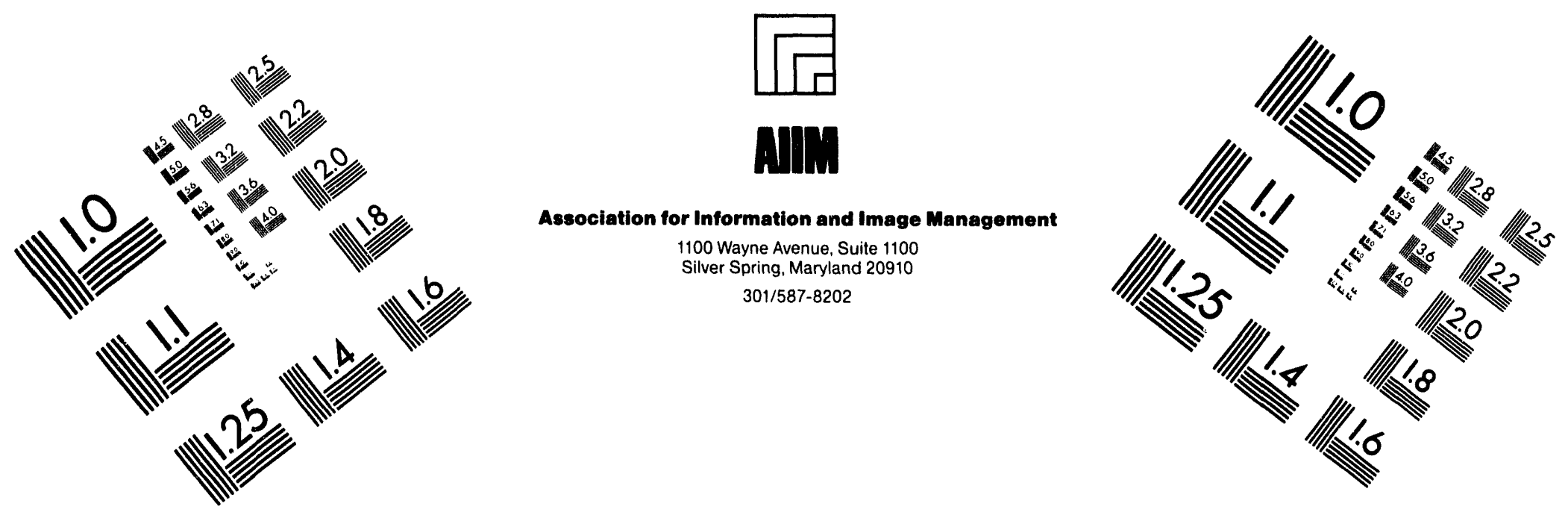

\title{
Centimeter
}

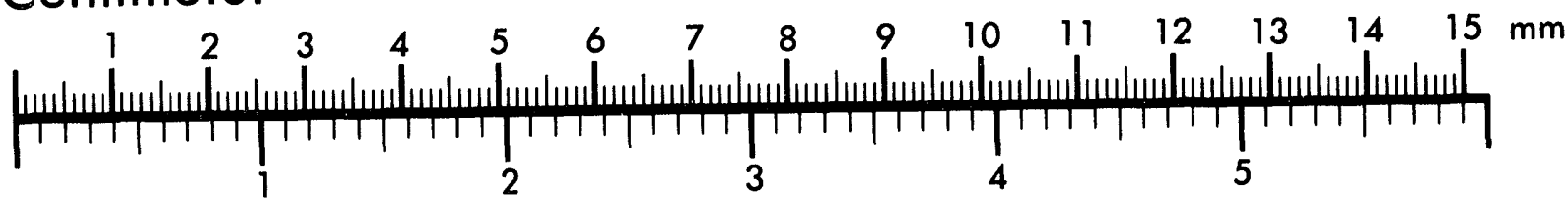
Inches
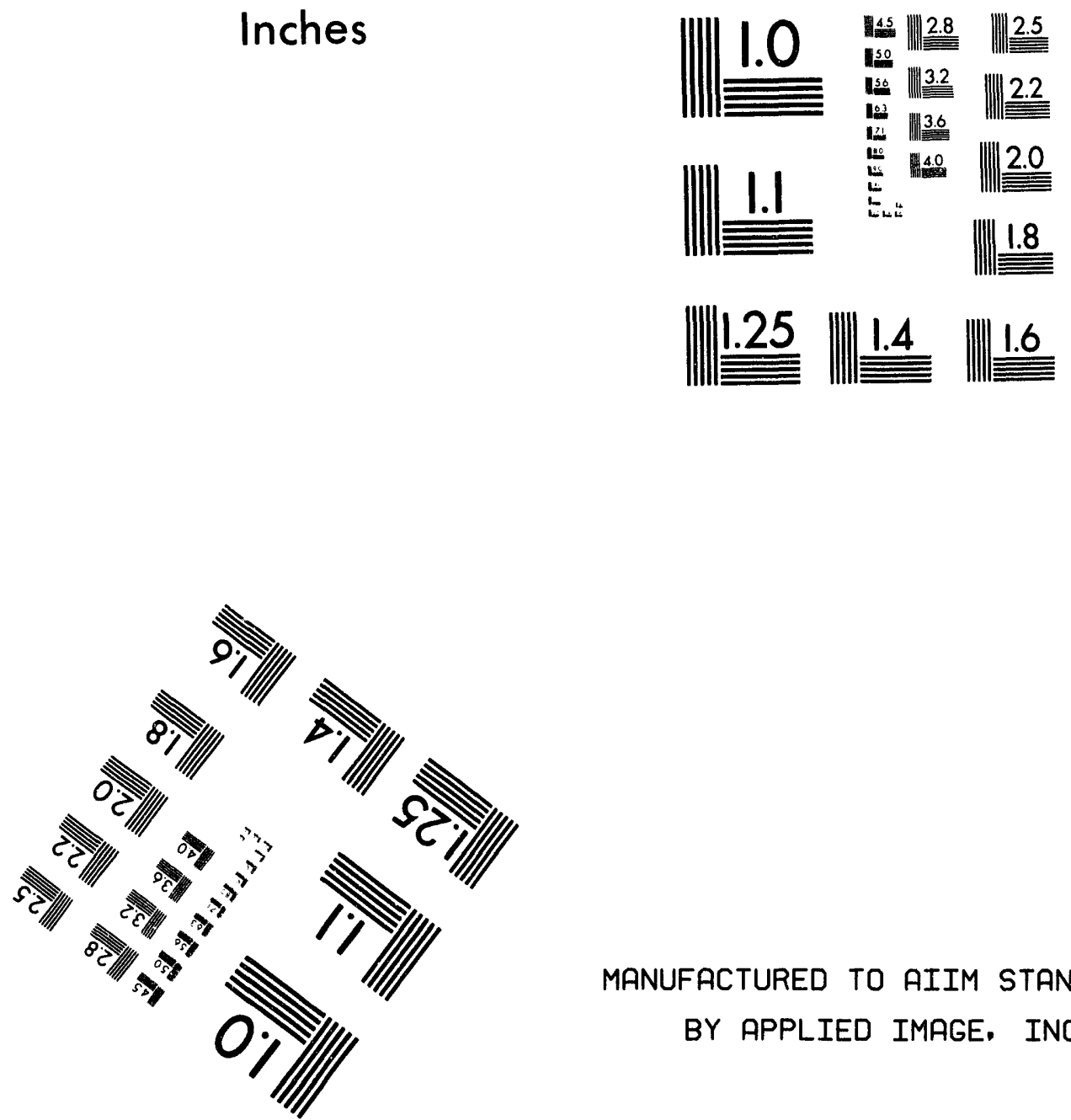

MANUFACTURED TO AIIM STANDARDS BY APPLIED IMAGE. INC.

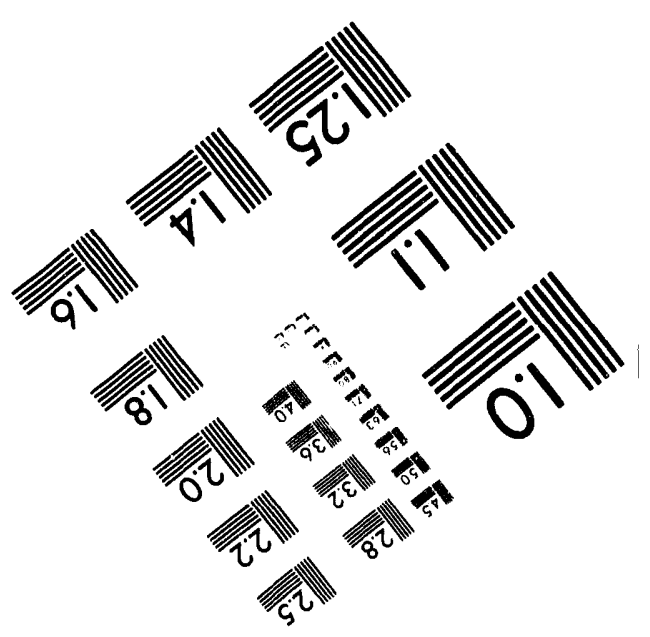



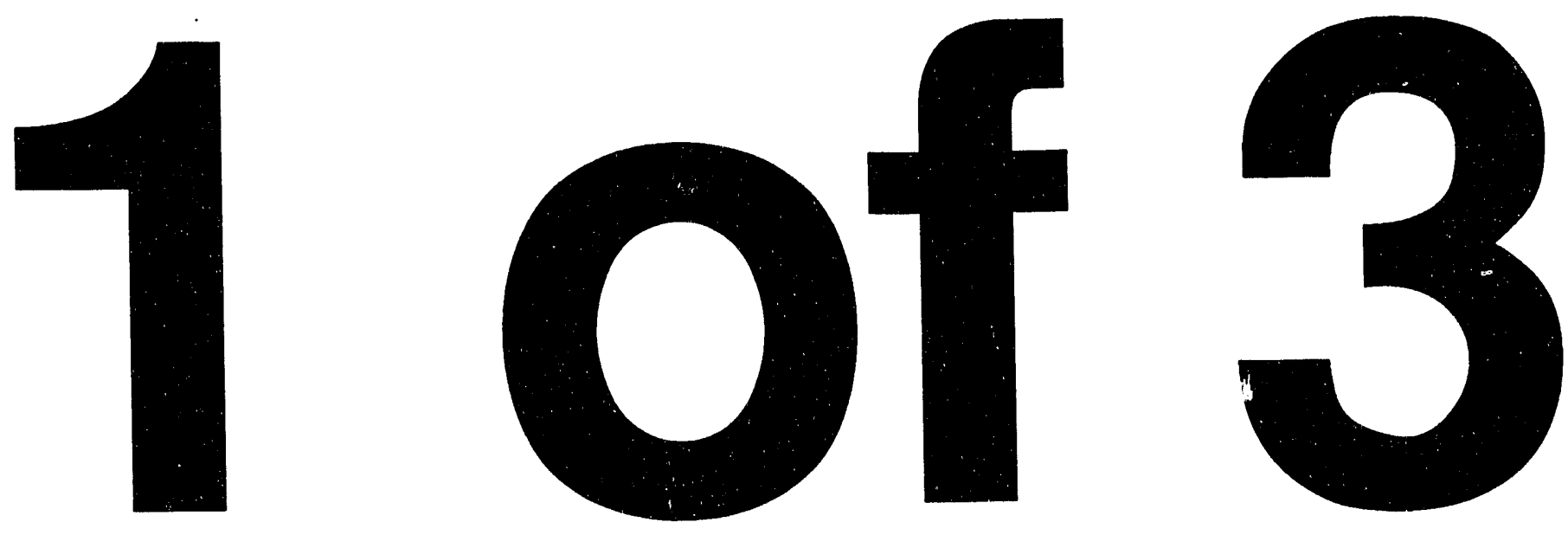


\section{High-Level Waste Storage Tank Farms/242-A Evaporator Standards/Requirements Identification Document (S/RID), Vol. 6}

Date Published

April 1994

Prepared for the U.S. Department of Energy Office of Environmental Restoration and Waste Management

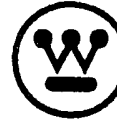




\section{LEGAL DISCLAIMER}

This report was prepared as an account of work sponsored by an agency of the United States Government. Neither the United States Government nor any agency thereof, nor any of their employees, nor any of their contractors, subcontractors or their employees, makes any warranty, express or implied, or assumes any legal liability or responsibility for the accuracy, completeness, or any third party's use or the results of such use of any information, apparatus, product, or process disclosed, or represents that its use would not intringe privately owned rights. Reference herein to any specific commercial product, process, or service by trade name, trademark, manufacturer, or otherwise, does not necessarily constitute or imply its endorsement, recommendation, or favoring by the United States Government or any agency thereof or its contractors or subcontractors. The views and opinions of authors expressed herein do not necessarily state. or reflect those of the United States Government or any agency thereot.

This report has been reproduced from the best available copy. Available in paper copy and microtiche.

Available to the U.S. Department of Energy and its contractors from

Office of Scientific and Technical Information P.O. Box 62

Oak Ridge, TN 37831

(615) $576-8401$

Available to the public from the U.S. Department of Commerce National Technical Information Service

5285 Port Royal Road

Springtield VA 22161

(703) $487-4650$

Printed in the United States of America 


\section{WESTINGHCUSE HANFORD COMPANY}

\section{REQUIREMENTS}

.1.

\section{IDENTIFICATION}

DOCUMENT

FACILITY:

HIGH LEVEL WASTE STORAGE TANK FARMS/242-A EVAPORATOR
FUNCTIONAL AREA:

Environmental Restoration and

Waste Management 


\section{REQUIREMENTS IDENTIFICATION DOCUMENT \\ HIGH LEVEL WASTE STORAGE TANK FARMS \\ Environmental Restoration and Waste Management \\ Revision 0}

\section{TABLE OF CONTENTS}

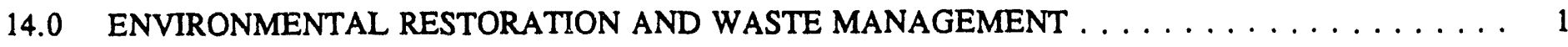

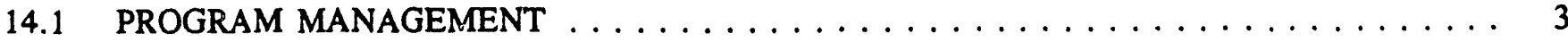

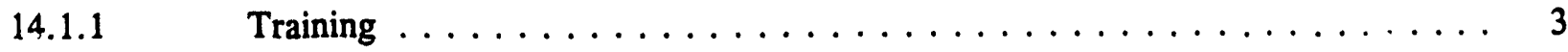

14.2 WASTE MANAGEMENT $\ldots \ldots \ldots \ldots \ldots \ldots \ldots \ldots \ldots \ldots \ldots \ldots \ldots$

14.2.1 High-Level Waste Management $\ldots \ldots \ldots \ldots \ldots \ldots \ldots \ldots$

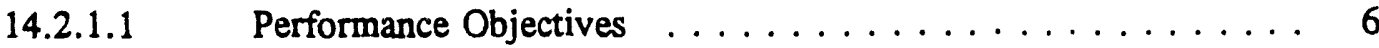

14.2.1.2 Design Activities . . . . . . . . . . . . . . . 7

14.2.1.3 Waste Characterization and Classification . . . . . . . . 10

14.2.1.4 Waste Manifest and Records . . . . . . . . . . . . 11

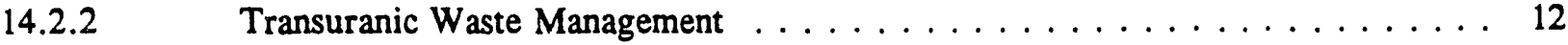

14.2.2.1 Waste Characterization and Classification . . . . . . . . 12

14.2.2.2 Waste Acceptance Criteria . . . . . . . . . . . . . 12

14.2.2.3 Waste Treatment, Storage, and Disposal . . . . . . . . . . 12

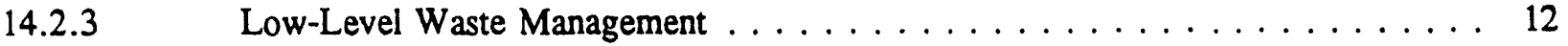

14.2.3.1 Performance Objectives $\ldots \ldots \ldots \ldots \ldots \ldots \ldots \ldots$

14.2.3.2 Waste Characterization ................. 13

14.2.3.3 Waste Acceptance Criteria . . . . . . . . . . . . . . 14

14.2.3.4 Waste Treatment,Storage and Disposal . . . . . . . . . . . 14

14.2.3.5 Waste Manifest, Plans and Records . . . . . . . . . . . 15

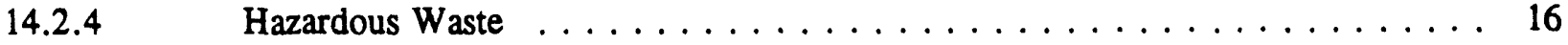

14.2.4.1 Design Activities . . . . . . . . . . . . . . . 17

14.2.4.2 General Waste Analysis . . . . . . . . . . . . . 17

14.2.4.3 Land Disposal Restrictions . . . . . . . . . . . . . . . 34

14.2.4.4 Surface Impoundments . . . . . . . . . . . . . . 35

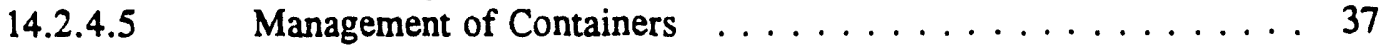

14.2.4.6 Waste Piles . . . . . . . . . . . . . . 40

14.2.4.7 Storage Time Limitations $\ldots \ldots \ldots \ldots \ldots \ldots \ldots$

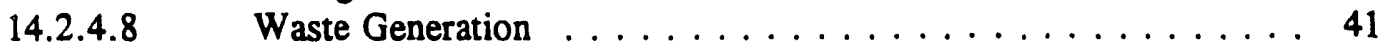

14.2.4.9 Waste Treatment . . . . . . . . . . . . . . 44

14.2.4.10 Waste Manifest, Plans and Records . . . . . . . . . . 45

14.2.4.11 Closure . . . . . . . . . . . . . . . . 50

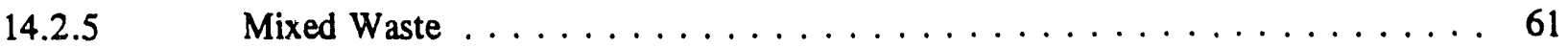




\section{REQUIREMENTS IDENTIFICATION DOCUMENT \\ HIGH LEVEL WASTE STORAGE TANK FARMS \\ Environmental Restoration and Waste Management \\ Revision 0}

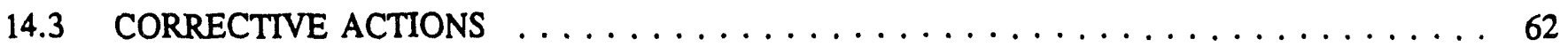

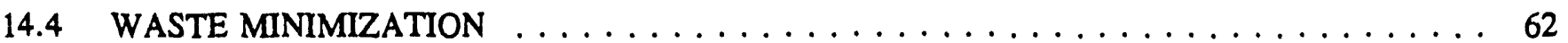

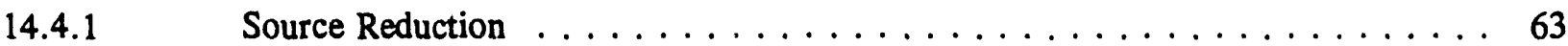

14.5 DECONTAMINATION AND DECOMMISSIONING $\ldots \ldots \ldots \ldots \ldots \ldots$

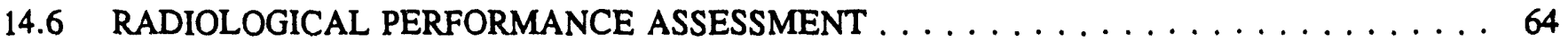

14.7 KEY PROGRAM INTERFACES $\ldots \ldots \ldots \ldots \ldots \ldots \ldots \ldots \ldots \ldots \ldots$

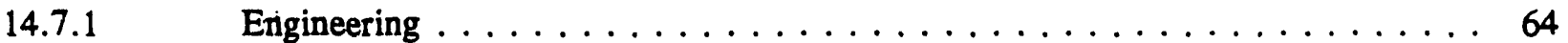

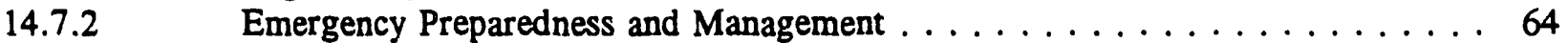

14.7.3 Research and Development and Experimental Activities (R\&D/EA) . . . . . 64

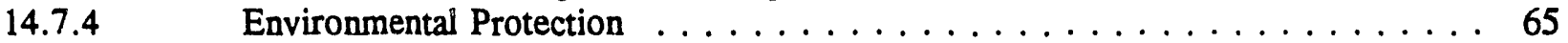

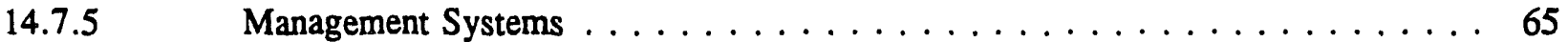

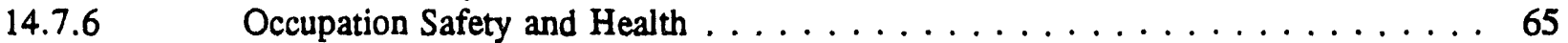

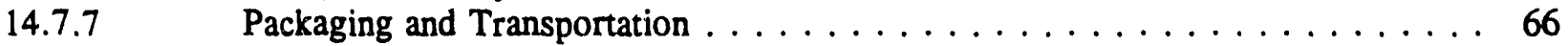

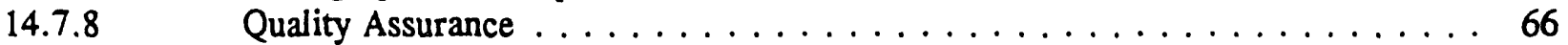

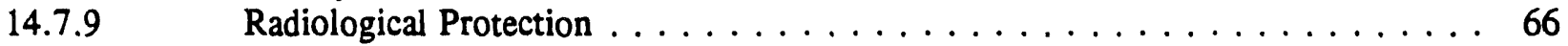

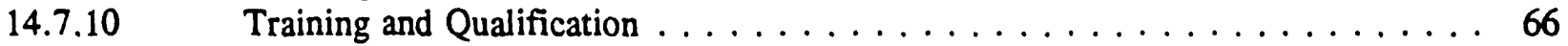

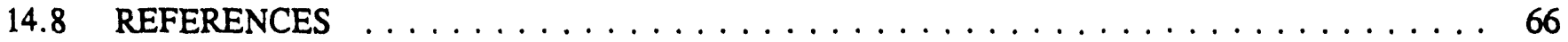




\section{REQUIREMENTS IDENTIFICATION DOCUMENT HIGH LEVEL WASTE STORAGE TANK FARMS Environmental Restoration and Waste Management Revision 0}

\subsection{ENVIRONMENTAL RESTORATION AND WASTE MANAGEMENT}

\section{INTRODUCTION}

The scope of the Environmental Restoration and Waste Management (EM) Functional Area includes the programmatic controls associated with the management and operation of the Hanford Tank Farm Facility. The driving management organization implementing the programmatic controls is the Tank Farms Waste Management (WM) organization whose responsibilities are to ensure that performance objectives are established; and that measurable criteria for attaining objectives are defined and reflected in programs, polices and procedures. Objectives for the WM Program include waste minimization, establishment of effective'waste segregation methods, waste treatment technology development, radioactive (low-level, high-level,) hazardous and mixed waste transfer, treatment, and storage, applicability of a corrective action programs, and management and applicability of a decontamination and decommissioning (D\&D)program in future years.

\section{SCOPE}

This functional area applies to the waste management programmatic controls, activities, personnel, and programs involved in executing the mission of the Tank Farms. The physical boundaries within which the requirements of this RIDapply are the Single Shell Tank Farms, Double Shell Tank Farms, 242-A Evaporator-Crystallizer, 242-S,T Evaporators, Liquid Effluent Retention Facility (LERF), Purgewater Storage Facility (PWSF), and all interconnecting piping, valves, instrumentation, and controls. Also included are all piping, valves, instrumentation, and controls up to and including the last locked valve under Tank Farms control at any other Hanford Facility having an interconnection with Tank Farms. The boundary of the structures, systems, components, and programs to which this RID applies, is defined by those that are dedicated to and/or under the control of the Tank Farms Waste Management Department and are specifically implemented at the Tank Farms.

The waste storage tanks provide for storage of high-level radioactive waste containing hazardous constituents. These tanks continue to receive waste periodically from various generators through piping and transfer truck. Although the wastes contain transuranic materials, they are not of a sufficient concentration to be classified as transuranic per DOE 5820.2A, therefore, technical requirements for TRU waste are not applicable. Tank Farms also generates low-level radioactive waste and low-level radioactive mixed waste resulting from operations and maintenance activities. Low-level radioactive waste is packaged and transported to Hanford disposal facilities. Mixed low-level radioactive wastes are packaged and transported to Hanford storage facilities.

Waste characterization is an ongoing activity at Tank Farms to analyze the physical, chemical, radiological and hazardous constituents of the stored waste. LDR constituents are contained in the waste and in waste generated andsent to Tank Farms. There are also nine tanks listed as containing wastes with greater tha: 10 weight percent organics, therefore, the interim status standards for organic bearing wastes apply to these tanks.

Tank Farms manages a hazardous waste treatment facility at the 242-A Evaporator. This facility is 


\section{REQUIREMENTS IDENTIFICATION DOCUMENT \\ HIGH LEVEL WASTE STORAGE TANK FARMS \\ Environmental Restoration and Waste Management \\ Revision 0}

designed to evaporate the stored tank wastes forthe purpose of volume reduction. The evaporator distillate, which contains hazardous constituents, is routed to an engineered surface impoundment where it is stored for eventual treatment by the Effluent Treatment Facility.

Tank Farms also stores waste in the forms of waste piles. These waste piles are primarily value pits with concrete covers. Waste includes failed equipment and other wastes contaminated with radioactive materials and hazardous constituents.

The following list identifies the programmatic elements in the EM functional area. Corrective Actions, D\&D, and Radiological Performance Assessment are considered not applicable to the current scope of Tank Farms activities.

1) Program Management

2) Waste Management

3) Corrective Actions

4) Waste Minimization

5) Decontamination and Decommissioning

6) Radiological Performance Assessment

7) Key Program Interfaces 


\section{REQUIREMENTS IDENTIFICATION DOCUMENT \\ HIGH LEVEL WASTE STORAGE TANK FARMS \\ Environmental Restoration and Waste Management \\ Revision 0}

PROGRAM MANAGEMENT

This element addresses the unique aspects of program management that are an essential part of an effective WM Program for Tank Farms. The general aspects of management, policy, staffing, and training are addressed in the Tank Farm's Management Systems Requirement Identification Document.

The Tank Farms WM senior staff shall communicate a firm commitment to the safety, health, and general welfare of the Tank Farm's employees and the general public and the protection of the surrounding environment through the development, distribution and implementation of a formal policy. This policy should describe the philosophy and standards of excellence under which WM activities shall be conducted. This element should establish the policy requirements for an effective WM Program that ensures that a high level of performance in WM activities is achieved through effective implementation and control of those activities.

Procedures and controls are necessary to follow-out the Tank Farm's mission by (1) defining the goals and objectives that promote safe, reliable and efficient conduct of WM activities, (2) developing a consistent and auditable set of requirements, standards, and responsibilities for conducting WM activities, (3) defining expected performance levels for WM activities, (4) integrating policy statements into the Tank Farms WM Program and implementation procedures, and (5) assignment of responsibility for implementation of environmental management policies in these procedures and controls.

\section{Training}

This subelement element specifies the hazardous waste training requirements as specified in the Washington Administrative Code 173-303-330, "Personnel Training." Tank Farm's must ensure that a written training program is developed and provided to all Tank Farm personnel. Personnel training records of current personnel must be maintained for a specific period of time for all current and former employees.

\section{FACILITY REQUIREMENT SOURCE: DOE/EH0135 AX.2.9}

"Waste system operators are knowledgeable of the waste streams and the operations they are required to perform."

\section{FACILITY REQUIREMENT SOURCE: DOE/EH0135 AX.3.2}

"Personnel are trained in solid hazardous waste handling procedures and safety precautions, and in ALARA program objectives."

\section{FACILITY REQUIREMENT SOURCE: DOE/EH0135 AX.3.4}

"Procedures and training emphasize the importance of keeping the volume of solid hazardous waste to a minimum."

\section{FACILITY REQUIREMENT SOURCE: DOE5820.2A Chapter I, Section 3.b(5)}

\section{"Training}

(a) Operator training and qualification standards shall be developed and an up-to-date record of 


\section{REQUIREMENTS DENTIFICATION DOCUMENT \\ HIGH LEVEL WASTE STORAGE TANK FARMS \\ Environmental Restoration and Waste Management \\ Revision 0}

training status shall be maintained.

(b) Worker safety training must comply with the requirements of DOE 5480.1B and applicable EH Orders."

\section{FACILITY REQUIREMENT SOURCE: WAC-173 Section 303-330 (2)}

"Written training plan. The owner or operator shall develop a written training plan which must be kept at the facility and which must include the following documents and records:

(a) For each position related to dangerous waste management at the facility, the job title, the job description, and the name of the employee filling each job. The job description must include the requisite skills, education, other qualifications, and duties for each position;

(b) A written description of the type and amount of both introductory and continuing training required for each position; and

(c) Records documenting that facility personnel bave received and completed the training required by this section."

\section{FACILITY REQUTREMENT SOURCE: WAC-173 Section 303-330 (3)}

"Training records. Training records on current personnel must be kept until closure of the facility. Training records on former employees must be kept for at least three years from the date the employees last worked at the facility. Personnel training records may accompany personnel transferred within the same company."

\section{WASTE MANAGEMENT}

The Tank Farm Waste Management (WM) Program should ensure that performance objectives are established; and that measurable criteria for attaining objectives are defined and reflected in programs, policies and procedures. Objectives for the Tank Farms WM Program shall include (1) waste minimization, (2) criteria for exemptions and de-listing petitions, (3) establishment of effective waste segregation methods, (4) waste reuse/recycle processes, (5) waste treatment and treatment technology development, and (6) design criteria. Methods of design for specific waste type should be managed by the WM Program which provides the programmatic controls and procedures for adhering to the land disposal restrictions and design requirements for surface impoundments and waste piles. The Tank Farm WM Program should ensure that performance objectives are established; and that measurable criteria for attaining objectives are defined and reflected in programs and policies for all waste types.

The Waste Management (WM) Program should establish the programmatic controls associated with the management and operation of DOE radioactive and hazardous waste TSD. DOE waste, whether generated by processing, manufacturing, or research activities should be managed under the auspices of the WM Program. The Environmental Restoration Program is concerned with assessment and remediation of contaminated facilities and sites that are no longer a part of active operations. WM processes including treatment methodologies, process controls, engineered features, monitoring, sampling, and operating limits should be established. Site-specific WM Plans should be developed to address, as applicable, waste categories identified below. 


\title{
REQUIREMENTS IDENTIFICATION DOCUMENT \\ HIGH LEVEL WASTE STORAGE TANK FARMS \\ Environmental Restoration and Waste Management \\ Revision 0
}

\author{
High-Level Waste Management
}

This subelement defines the requirements and controls for high-level wastes treated and stored at the Hanford Tank Farm Facility. Specific administrative and engineering controls should be developed and implemented for tanks containing liquid high-level wastes to prevent spills, leaks, and overflow of tank systems. Controls must include a specific design criteria for high-level waste containment systems to ensure waste handling, transfer and storage of these materials are performed appropriately. Administrative response procedures should be implemented to ensure proper response to credible emergencies and mitigation planning to avoid reoccurrence. A mature high-level waste program must employ a comprehensive monitoring and surveillance program for the collection of liquid volume inventory data and a system for the identification of failed equipment. Performance objectives to determine the measurable criteria for attaining the objectives of the high-level waste management program should be established and integrated into the procedures and controls. The Tank Farm's high-level waste technologies should support the development and expansion of evaporator treatment and other waste management technologies that will ensure these are managed safely and are suitable for disposal.

\section{FACILITY REQUIREMENT SOURCE: DOE5820.2A Chapter I, Section 3.b(2)(h)}

"Engineering controls shall be incorporated to provide liquid volume inventory data and to prevent spills, leaks, and overflows from tanks or containment systems. Examples are level-sensing devices, liquid level alarms, and maintenance of sufficient freeboard. The high-level waste shall be stored at pressures lower than those of ancillary systems (e.g., cooling water)."

\section{FACIITY REQUIREMENT SOURCE: DOE5820.2A Chapter I, Section 3.b(2)(k)}

"Upon loss and subsequent recovery of normal electrical power, high-level waste transfer equipment shall not bave the capability to restart without active operator action."

\section{FACILITY REQUTREMENT SOURCE: DOE5820.2A Chapter I, Section 3.b(2)a}

"Storage and Transfer Operations

(a) All new high-level waste handling, transfer, and storage facilities (e.g., tanks, bins, pipelines, and capsules) shall be doubly contained."

\section{FACILITY REQUIREMENT SOURCE: DOE5820.2A Chapter I, Section 3.b(4)(d)}

"For emergency situations involving liquid high-level waste, spare capacity with adequate heat dissipation capability shall be maintained to receive the largest volume of liquid contained in any one tank. Adequate transfer pipelines also shall be maintained in operational condition. Interconnected tank farms with adequate transfer capabilities and spare capacity may be considered as a single tank farm for purposes of this requirement."

\section{FACILITY REQUIREMENT SOURCE: DOE5820.2A Chapter I, Section 3.b(4)(f)}

"Each high-level waste facility shall have response procedures for credible emergencies, as identified in the Safety Analysis Reports." 


\section{REQUIREMENTS IDENTIFICATION DOCUMENT \\ HIGH LEVEL WASTE STORAGE TANK FARMS \\ Environmental Restoration and Waste Management \\ Revision 0}

FACILITY REQUIREMENT SOURCE: DOE5820.2A Chapter I, Section 3.c(2)(a)

"Storage and Transfer Operations

(a) Singly contained tank systems shall not be used to store fresh high-level waste from fuel reprocessing operations except under emergency conditions as determined by the Operations Office Manager."

\section{FACILITY REQUIREMENT SOURCE: DOE5820.2A Chapter I, Section 3.c(3)}

"Monitoring, Surveillance, and Leak Detection

(a) Monitoring and surveillance capability shall exist to provide liquid volume, waste inventory data, and identification of failed containment.

(b) A method for periodically assessing waste storage tank integrity (e.g., coupons, photographic inspections, leak detectors, liquid level devices) shall be established and documented.

(c) Emergency power (see paragraph 3.b.(3)(d)).

(d) Monitoring wells (see paragraph 3.b.(3)(f))."

FACIITY REQUIREMENT SOURCE: DOE5820.2A Chapter I, Section 3.d(1)(c)

"Other Waste. High-level waste that is not readily retrievable shall be monitored periodically in situ. Field offices shall reevaluate the safety of such waste to determine the need for corrective measures as necessary. Options for permanent disposal of singly contained tank waste shall be evaluated and include such methods as in-place stabilization as well as retrieval and processing, as required for new and readily retrievable waste in paragraph 3.d.(1)."

\section{Performance Objectives}

A performance objective program for high-level waste management should be developed that establishes a performance base criteria which is monitored to ensure adherence to the dose limit requirements of 40 CFR 191. Facility procedures and controls should be developed and in-place to grant reasonable assurance that the combine dose equivalent to any member of the general public resulting from discharges of radioactive material do not exceed the limits specified by this regulation. The performance objective program should be reevaluated frequently to incorporated facility changes in mission philosophy, and material upgrades.

\section{SITE REQUIREMENT SOURCE: DOE5400.5 Chapter II, Section 1(c)(1)}

" 40 CFR Part 191. The dose limits as outlined in paragraph II.1c, are established by Section 191.03(b) of EPA regulation 40 CFR Part 191, Subpart A, "Environmental Standards for Management and Storage." The implementation of the requirements of Subpart B, "Environmental Standards for Disposal," is beyond the scope of this Order. DOE waste management and storage activities at facilities other than disposal facilities are subject to the dose limits outlined in paragraph ПI.1c. The Waste Isolation Pilot Plant, for purposes of this Order, is considered to be a disposal facility subject to this Order and 40 CFR Part 191. Other requirements and guidelines for the management and storage of spent nuclear fuel and 


\section{REQUIREMENTS IDENTIFICATION DOCUMENT HIGH LEVEL WASTE STORAGE TANK FARMS \\ Environmental Restoration and Waste Management Revision 0}

high-level and transuranic waste at DOE facilities that are not licensed by the NRC are given in DOE 5820.2A."

\section{FACILITY REQUIREMENT SOURCE: DOE5820.2A Chapter I, Section 3.b(4)(e)}

"A schedule and procedure shall be developed for monitoring, surveillance, and calibration checks. The frequency of these activities shall be based on the potential rate of equipment deterioration and the possibility of an environmental or human health incident, assuming that a malfunction from equipment failure or human error is not detected between checks. Schedules, procedures, and performance requirements shall be documented in the operating and maintenance documentation."

Design Activities

The application of high-level waste design methodologies must be perform in accordance with DOE 6430.1A, applicable DOE Environmental Restoration and Waste Management Orders, and 40 CFR 264. Tank system designs must ensure protection to the public and facility personnel from all hazards of high-level waste associated with operations, accident conditions, and natural phenomena.

\section{SITE REQUIREMENT SOURCE: DOE-RL-5820.2A Chapter I.3.b(2)}

"Storage and Transfer Operations

(a) Underground tanks used for the storage of newly-generated liquid radioactive waste shall be doubled contained.

(b) The cross-country pipelines between 200-East and 200-West may be used on a temporary basis for the transfer of waste with an activity higher than $0.05 \mathrm{Ci} / \mathrm{gal}$ only if appropriate design and administrative controls are in place to mitigate adverse effects from a pipeline failure. Minimum appropriate design and administrative control are as follows:

1. Pressure-check the line before use.

2. Procedures shall be in place to identify if radioactive liquid leaks from the pipe into the concrete encasement enclosing the pipe."

\section{SITE REQUIREMENT SOURCE: DOE5820.2A Chapter I, Section 3.a}

"Design. (1) Requirements for New Facilities.

(a) Design objectives for new facilities will assure protection of the public and operating personnel from hazards associated with normal high-level waste operations, accident conditions, and the effects of natural phenomena. Other objectives are compliance with DOE policies regarding nuclear safety, quality assurance, fire protection, pollution control, and safeguards and security protection for high-level waste and protection of essential operations from the effects of potential accidents.

(b) Designs for new storage and treatment facilities shall meet the requirements of DOE 6430.1, applicable EM Orders and 40 CFR 264. 


\section{REQUIREMENTS IDENTIFICATION DOCUMENT HIGH LEVEL WASTE STORAGE TANK FARMS Environmental Restoration and Waste Management \\ Revision 0}

(c) Designs for new storage facilities shall incorporate features to facilitate retrieval capability.

(2) Design Review for Existing Facilities. Uniform requirements for the preparation of safety analysis reports for high-level waste operations, detailed in DOE 5481.1B, include the review of existing operational facilities based on current technical criteria. When hazards are identified that should be eliminated, controlled, or mitigated, appropriate upgrading, actions in accordance with paragraph 3a(1) above, shall be identified and implemented according to the requirements of DOE 5481.1B."

\section{SITE REQUIREMENT SOURCE: DOE5820.2A Chapter I, Section 3.b(2)(b)}

"Singly contained pipelines may be used routinely for liquid waste that has a total radioactivity concentration of less than $0.05 \mathrm{Ci} / \mathrm{gal}(4.9 \times 10 / 11 \mathrm{Bg} / \mathrm{m} 3)$. They may be used on a temporary basis for higher activity waste, if appropriate design and administrative controls are in place to mitigate adverse effects from a pipeline failure."

\section{SITE REQUIREMENT SOURCE: DOE5820.2A Chapter I, Section 3.b(2)(c)}

"Leaking waste storage systems shall not be used to receive waste unless secondary containment is maintained (e.g., liquid level maintained below leak point) and it can be shown with the support of formal documentation (e.g., Safety Analysis Reports, Operational Safety Requirements, Operating Standards) that temporary operation can be performed without releasing radioactive liquid to the environment."

\section{SITE REQUIREMENT SOURCE: DOE5820.2A Chapter I, Section 3.b(2)(d)}

"Secondary containment systems shall be capable of containing liquids that leak into them from the primary system and shall be equipped with transfer capability to retrieve the leaked liquid. Secondary containment systems for solidified high-level waste shall provide for physical isolation of the waste from the environment."

\section{SITE REQUIREMENT SOURCE: DOE5820.2A Chapter I, Section 3.b(2)(e)}

"To the extent practical, waste shall be segregated by type (sludge, salt, high activity, and low activity) to make accessibility for future processing easier."

\section{SITE REQUIREMENT SOURCE: DOE5820.2A Chapter I, Section 3.b(2)(f)}

"Where required, ventilation and filtration systems shall be provided to maintain radionuclide releases within the guidelines specified in DOE 5481.1B and applicable EM Orders. Ventilation systems shall be provided where the possibility exists for generating flammable and explosive mixtures of gases (e.g., bydrogen/air or organic/air)."

\section{SITE REQUIREMENT SOURCE: DOE5820.2A Chapter I, Section 3.b(2)(g)}

"Facilities using cathodic corrosion protection systems shall include engineered features that protect against abnormal conditions such as stray currents or system failure. The cathodic protection systems shall be calibrated annually, and all sources of impressed current shall be inspected and/or tested at least every other month." 


\section{REQUIREMENTS IDENTIFICATION DOCUMENT \\ HIGH LEVEL WASTE STORAGE TANK FARMS \\ Environmental Restoration and Waste Management

\author{
Revision 0
}

\section{SITE REQUIREMENT SOURCE: DOE5820.2A. Chapter I, Section 3.b(2)(i)}

"Nuclear criticality safety considerations and controls shall be evaluated for normal operations and, before any significant operational changes are made, to protect against an uncontrolled nuclear criticality incident (e.g., dissolution of sludges for removal from tank)."

\section{SITE REQUIREMENT SOURCE: DOE5820.2A Chapter I, Section 3.b(2)(j)}

"Each facility shall utilize remote maintenance features and other appropriate techniques to minimize personnel radiation exposure in accordance with DOE 5481.1B."

\section{SITE REQUIREMENT SOURCE: DOE5820.2A Chapter I, Section 3.b(3)(a)}

"Monitoring and lead detection capability shall be incorporated in the engineering systems (e.g., liquid level sensing devices and alarms for high-level waste liquid systems) to provide rapid identification of failed containment, and measurement of abnormal temperatures. The following, at a minimum, shall be monitored; temperature; pressure; radioactivity in ventilation exhaust; and liquid effluent streams associated with high-level waste facilities. Where the possibility exists for the generation of flammable and explosive mixtures of gases, monitoring shall be conducted. For facilities storing liquid high-level waste, the following should also be monitored: liquid levels; sludge volume; tank chemistry; condensate and cooling water."

\section{SITE REQUIREMENT SOURCE: DOE5820.2A Chapter I, Section 3.b(3)(b)}

"Leak detection systems (e.g., conductivity probes) shall be designed and operated so that they will detect the failure of the primary containment boundary, the occurrence of waste release, or accumulated liquid in the secondary containment system."

\section{SITE REQUIREMENT SOURCE: DOE5820.2A Chapter I, Section 3.b(3)(c)}

"A method for periodically assessing waste storage system integrity (e.g., coupons for corrosion testing, photographic and periscopic inspections, leak detectors, liquid level devices) shall be established, documented, and reported as required in the Waste Management Plan."

\section{SITE REQUIREMENT SOURCE: DOE5820.2A Chapter I, Section 3.b(3)(d)}

"Electrical monitoring and leak detection devices essential to safe operations shall be provided with backup power, as appropriate, to easure operability under emergency conditions. "

\section{SITE REQUIREMENT SOURCE: DOE5820.2A Chapter I, Section 3.b(4)(a)}

"A tank or secondary containment system from which there has been a leak or a spill to the surrounding soil, or which is otherwise unfit for use, shall be removed from service until conditions can be evaluated fully."

\section{SITE REQUIREMENT SOURCE: DOE5820.2A Chapter I, Section 3.b(4)(b)}

"Upon detection of released radioactive materials, steps shall be taken to prevent further migration of the release to soil or surface water. Major contamination in the soil shall be removed or stabilized unless compliance with this requirement would cause greater harm to 


\section{REQUIREMENTS IDENTIFICATION DOCUMENT \\ HIGH LEVEL WASTE STORAGE TANK FARMS \\ Environmental Restoration and Waste Management \\ Revision 0}

human health or the environment."

SITE REQUIREMENT SOURCE: DOE5820.2A Chapter I, Section 3.b(4)(c)

"If a release results from a spill and the integrity of the system is not damaged, the system may be returned to service as soon as action to correct the condition is completed."

\section{SITE REQUIREMENT SOURCE: DOE5820.2A Chapter I, Section 3.b(5)(a)}

"Operator training and qualification standards shall be developed and an up-to-date record of training status shall be maintained."

\section{SITE REQUIREMENT SOURCE: DOE5820.2A Chapter I, Section 3.b(7)(d)}

"Treatment reagents shall not be placed in a tank system without proven effective mitigative action if they could cause the tank, its ancillary equipment, or the containment system to rupture, leak, or otherwise fail."

\section{STTE REQUIREMENT SOURCE: DOE5820.2A Chapter I, Section 3.c(2)(b)}

"Storage and transfer operations shall be conducted within the limits defined in the Safety Analysis Reports according to DOE 5481.1B."

\section{SITE REQUIREMENT SOURCE: DOE5820.2A Chapter I, Section 3.c(2)(e)}

"Where active ventilation is required, systems shall be provided to maintain radionuclide releases at the point of discharge within the guidelines specified in applicable EH Orders for offsite concentrations and DOE 5480.1B for onsite dose commitment considerations.

\section{SITE REQUIREMENT SOURCE: DOE5820.2A Chapter I, Section 3.c(2)(g)}

"Each facility shall use remote maintenance features and other appropriate techniques to maintain personnel radiation exposure as low as reasonably achievable."

\section{SITE REQUIREMENT SOURCE: DOE5820.2A Chapter I, Section 3.c(4)(a)}

"A contingency action plan shall be maintained to respond to spills or leaks and other credible emergencies as identified in the Safety Analysis Reports."

\section{SITE REQUIREMENT SOURCE: DOE5820.2A Chapter I, Section 3.c(4)(c)}

"For emergency situations involving pumpable liquid in singly contained tanks, appropriate equipment (e.g., pumps) shall be maintained to provide removal of liquid."

\section{Waste Characterization and Classification}

A high-level waste characterization program should be developed and include provisions to determine the hazardous components of the waste per 40 CFR 261, 40 CFR 264, and associated WAC regulations. High-level waste characterization and compatibility information must be obtained and documented in all applicable Tank Farm Facility Safety Analysis 


\section{REQUIREMENTS IDENTIFICATION DOCUMENT \\ HIGH LEVEL WASTE STORAGE TANK FARMS \\ Environmental Restoration and Waste Management \\ Revision 0}

Reports. Operational controls should include requirements to adjust the chemistry of liquid high-level waste to control and minimize corrosion in the all tank systems.

\section{FACILITY REQUIREMENT SOURCE: DOE5820.2A Chapter I, Section 3.b(1)}

"Storage Operations - Doubly Containel Systems Waste Characterization

(a) Liquid and solidified high-level waste shall be characterized consistent with radiation protection requirements to determine its hazardous components, per 40 CFR 261 and 40 CFR 264. Characterization shall satisfy requirements of paragraph 3.b.(1)(b) and may reflect knowledge of waste generating processes, laboratory testing results, and/or the results of periodic sampling and analysis. Examples of required information are chemical composition, physical properties, radionuclide concentrations, and $\mathrm{pH}$.

(b) Waste characteristics and compatibility information shall be documented in a safety analysis report (see DOE 5481.1B) and be used as a basis for designing new facilities."

FACILITY REQUIREMENT SOURCE: DOE5820.2A Chapter I, Section 3.b(7)(c)

"The chemistry of liquid high-level waste shall be adjusted to control corrosion within design limits for the storage system."

\section{FACILITY REQUIREMENT SOURCE: DOE5820.2A Chapter I, Section 3.b(7)(e)}

"Waste generation and waste management systems that significantly change the chemical and physical forms of the waste shall be technically assessed to assure compatibility and retrievability."

\section{FACIIITY REQUIREMENT SOURCE: DOE5820.2A Chapter I, Section 3.c(1)}

"Storage Operations - Singly Contained Tank Systems

(1) Waste Characterization. The contents of singly contained tank systems shall be characterized consistent with radiation protection requirements and the needs associated with safe storage to determine its hazardous components consistent with 40 CFR 261, 40 CFR 264, and State requirements. Characterization may reflect knowledge of waste generating processes, laboratory testing results, and/or the results of periodic sampling and analysis."

\section{Waste Manifest and Records}

This subelement is designed to address the waste manifest and recordkeeping requirements for the high-level waste at the Tank Farm Facility. Operational controls should include the collection of current waste volume inventories of tanks containing high-level liquid waste materials. Waste inventory data must be captured and archived from all past and present systems to allow the establishment of trend analyses and long term inventory assessments. Controls need to be established to maintain manifests and document waste identification, characterization of the waste, generator identification, carrier and receiver identification and applicable permit information. 


\section{REQUIREMENTS IDENTIFICAI:ON DOCUMENT HIGH LEVEL WASTE STORAGE TANK FARMS \\ Environmental Restoration and Waste Management

\author{
Revision 0
}

\section{FACILITY REQUIREMENT SOURCE: DOE5820.2A Chapter I, Section 3.c(2)(c)}

"Engineered systems shall be incorporated to provide waste volume inventory data, consistent with the nature of the specific waste stored in singly contained tanks. Examples are surface level sensing devices and interstitial liquid level sensing devices."

$\underline{14.2 .2}$

$\underline{14.2 .2 .1}$

$\underline{14.2 .2 .2}$

14.2 .2 .3

$\underline{14.2 .3}$

\section{Transuranic Waste Management}

Not applicable.

\section{Waste Characterization and Classification}

This subelement defines the requirements of evaluating TRU wastes at the Tank Farm Facility by methods of assay, laboratory analysis, or process knowledge. TRU Characterization of waste streams shall be performed to determine (1) the physical and chemical characteristics of the waste, (2) absorbent characteristics, (3) waste volume, (4) and radionuclides distribution, concentration, and activity.

\section{Waste Acceptance Criteria}

This subelement is designed to define the programmatic requirements of the Tank Faross TRU waste acceptance criteria when receiving waste from other Hanford Facilities.

Waste Treatment. Storage, and Disposal

Waste treatment, storage, and disposal procedures and controls must be defined and implemented for management of TRU waste within Tank Farms. Monitoring programs should be in place to ensure that liquid waste are not releasing radiological or hazardous constituents. Components of a mature TSD program should contain waste reduction controls, ALARA principles in waste handling, monitoring methods, design, construction and maintenance operations to minimize the possibilities of fire, explosion, or release of liquid materials.

\section{Low-Level Waste Management}

This subelement defines the requirements and controls for low-level wastes treated and stored at the Hanford Tank Farm Facility. Controls for low-level radioactive wastes should ensure they are manuged, in accordance with DOE Policy, in a manner that assures protection of the health and safety of the public, DOE and contractor employees, and the environment. This subelement includes the requirements of DOE Order 5820.2A for low-level radioactive waste management applicable to the Tank Farm Facility.

Procedures and controls shall be developed and implemented that adheres to the requirements of ALARA and maintains the performance objectives of the facility. These controls must provide a clear definition of the low-level waste characteristics to determine the Curie content and volume inventory of each tank's effluents. A waste acceptance criteria must be established that addresses the allowable quantities/concentrations of specific radionuclides being treated and stored at Tank Farms. The implementation of waste treatment methods must be fully explored that are necessary to meet or exceed the performance objectives of the facility. 


\section{REQUIREMENTS IDENTIFICATION DOCUMENT HIGH LEVEL WASTE STORAGE TANK FARMS Environmental Restoration and Waste Management Revision 0}

\section{Performance Objectives}

The Tank Farms WM Program should ensure that performance objectives are established through the use of procedures, controls and training; and that measurable criteria for attaining objectives are defined and reflected in programs, policies and procedures. Objectives for the WM Program should include waste minimization (source reduction), establishing and obtaining permits for TSD, criteria for exemptions and de-listing petitions, and establishment of effective waste segregation methods, establishing design criteria that optimize system performance, and cost/technically effective sampling and monitoring programs. This subelement defines the requirements of TSD requirements for Tank Farms.

\section{FACILITY REQUIREMENT SOURCE: DOE5820.2A Chapter III, Section 3.a(2)}

"Assure that external exposure to the waste and concentrations of radioactive material which may be released into surface water, ground water, soil, plants and animals results in an effective dose equivalent that does not exceed $25 \mathrm{mrem} / \mathrm{yr}$ to any member of the public. Releases to the atmosphere shall meet the requirements of 40 CFR 61. Reasonable effort should be made to maintain releases of radioactivity in effluents to the general environment as low as is reasonably achievable."

\section{Waste Characterization}

This subelement defines the controls necessary for fulfilling the requirements for low-level waste management at the Tank Farm Facility. The WM Program should ensure that methodologies are established and procedures and criteria are developed for characterization of liquid wastes. The characterization of waste should include a systematic approach in determining a general grouping according to hazard type, e.g., radioactive waste, hazardous waste and mixed waste to avoid commingling of waste storage at the facility. Waste should be characterized to determine the total Curie content and volume inventory of the liquid waste and a facility effluent inventory of any or all effluent discharging from Tank Farms. Detailed analysis may include specific radionuclides identification, activity level determination, specification and concentration of other facility.

\section{FACILITY REQUIREMENT SOURCE: DOE/EH0135 AX.2.15}

"Total Curie content and volume of facility effluents are accurately determined and recorded; trends are determined and evaluated."

FACILITY REQUIREMENT SOURCE: DOE5820.2A Chapter II, Section 3.d(1)

"Waste Characterization

(1) Low-level waste shall be characterized with sufficient accuracy to permit proper segregation, treatment, storage, and disposal. This characterization shall ensure that, upon generation and after processing, the actual physical and chemical characteristics and major radionuclide content are recorded and known during all stages of the waste management process."

FACILITY REQUIREMENT SOURCE: DOE5820.2A Chapter III, Section 3.d(2)

"Waste characterization data shall be recorded on a waste manifest, as required by paragraph 


\section{REQUIREMENTS IDENTIFICATION DOCUMENT HIGH LEVEL WASTE STORAGE TANK FARMS Environmental Restoration and Waste Management Revision 0}

3.m., and shall include:

(a) The physical and chenical characteristics of the waste;

(b) Volume of the waste (total of waste and any solidification or absorbent media);

(c) Weight of the waste (total of waste and any solidification or absorbent media);

(d) Major radionuclides and their concentrations;

(e) Packaging date, package weight, and external volume."

FACIITY REQUTREMENT SOURCE: DOE5820.2A Chapter II, Section 3.d(3)

"The concentration of a radionuclide may be determined by direct methods or by indirect methods such as use of scaling factors which relate the inferred concentration of one radionuclide to another that is measured, or radionuclide material accountability, if there is reasonable assurance that the indirect methods can be correlated with actual measurements."

\section{Waste Acceptance Criteria}

The Tank Farm Facility WM Program should identify waste acceptance criteria for receiving waste from other Hanford Facilities. This element defines the controls necessary for establishing an acceptance criteria. A Waste Acceptance criteria must have technical bases developed in accordance with the Tank Farms Facility specific requirements. Procedures should ensure that only those wastes are accepted that the facility is capable and permitted to handle. Additionally, acceptance criteria for Tank Farms should include criteria for tank design to ensure that tanks are compatible with the wastes in consideration of the intended storage duration and conditions.

\section{FACILITY REQUIREMENT SOURCE: DOE5820.2A Chapter III, Section 3.e(3)}

"Generators of waste shall implement a low-level waste certification program to provide assurance that the waste acceptance criteria for any low-level waste treatment, storage, or disposal facility used by the generator are met. Generators and facilities receiving the waste are jointly responsible for assuring compliance with waste acceptance criteria. Generators are financially responsible for actions required due to non-conformance."

\section{FACILITY REQUIREMENT SOURCE: DOE5820.2A Chapter III, Section 3.e(4)}

"Generator low-level waste certification programs shall be subject to a periodic audit by operators of facilities to which the waste is sent by the generator."

\section{Waste Treatment. Storage and Disposal}

The WM Program should ensure that appropriate TSD facilities are established and operated in accordance with permit requirements for low-level waste. This subelement defines the requirements for short- and long-term storage areas and interim lay-down areas for low-level wastes. Programmatic controls should implement treatment techniques for low-level wastes at the facility. 


\title{
REQUIREMENTS IDENTIFICATION DOCUMENT HIGH LEVEL WASTE STORAGE TANK FARMS Environmental Restoration and Waste Management Revision 0
}

FACILITY REQUIREMENT SOURCE: DOE5820.2A Chapter III, Section 3.f(1)

"Waste Treatment

(1) Waste shall be treated by appropriate methods so that the disposal site can meet the performance objectives stated in paragraph 3.a."

FACILITY REQUIREMENT SOURCE: DOE5820.2A Chapter III, Section 3.f(2)

\begin{abstract}
"Waste treatment techniques such as incineration, shredding, and compaction to reduce volume and provide more stable waste forms shall be implemented as necessary to meet performance req-irements. Use of waste treatment techniques to increase the life of the disposal facility and improve long-term facility performance, by improved site stability and reduction of infiltrating water, is required to the extent it is cost effective."
\end{abstract}

\section{FACILITY REQUIREMENT SOURCE: DOE5820.2A Chapter II, Section 3.i(5)(a)}

"The following are additional disposal requirements intended either to improve stability of the disposal site or to facilitate handling and provide protection of the health and safety of personnel at the disposal site:

(a) Waste must not be packaged for disposal in cardboard or fiberboard boxes, unless such boxes meet DOT requirements and contain stabilized waste with a minimum of void space. For all types of containers, void spaces within the waste and between the waste and its packaging shall be reduced as much as practical."

FACILITY REQUIREMENT SOURCE: DOE5820.2A Chapter III, Section 3.i(5)(b)

"Liquid wastes, or wastes containing free liquid, must be converted into a form that contains as little freestanding and noncorrosive liquid as is reasonably achievable, but, in no case, shall the liquid exceed 1 percent of the volume of the waste when the waste is in a disposal container, or 0.5 percent of the volume of the waste processed to a stable form. "

\section{FACILITY REQUIREMENT SOURCE: DOE5820.2A Chapter II, Section 3.i(5)(c)}

"Waste must not be readily capable of detonation or of explosive decomposition or reaction at normal pressures and temperatures, or of explosive reaction with water."

FACILITY REQUIREMENT SOURCE: DOE5820.2A Chapter II, Section 3.i(5)(d)

"Waste must not contain, or be capable of generating, quantities of toxic gases, vapors, or fumes harmful to persons transporting, handling, or disposing of the waste. This does not apply to radioactive gaseous waste packaged as identified in paragraph 3.i.(5)(e)."

\section{Waste Manifest. Plans and Records}

This subelement is designed to address the waste manifest and recordkeeping requirements for the low-level waste at the Tank Farm Facility. Operational controls should include the collection of current waste volume inventories of tanks containing low-level liquid waste materials. Waste inventory data must be captured and archived from all past and present systems to allow the establishment of trend analyses and long term inventory assessments. 


\section{REQUIREMENTS IDENTIFICATION DOCUMENT HIGH LEVEL WASTE STORAGE TANK FARMS Environmental Restoration and Waste Management \\ Revision 0}

Controls need to be established to maintain manifests and document waste identification, characterization of the waste, generator identification, carrier and receiver identification and applicable permit information.

\section{SITE REQUIREMENT SOURCE: DOE5820.2A Chapter III, Section 3.m(1)}

\section{"Records and Reports}

(1) Each field organization shall develop and maintain a record keeping system that records the following: a historical record of waste generated, treated, stored, shipped, disposed of, or both, at the facilities under its cognizance. The data maintained shall include all data necessary to show that the waste was properly classified, treated, stored, shipped, and/or disposed of. The data nuaintained in the system shall be based on the data recorded on waste manifests."

\section{FACILITY REQUTREMENT SOURCE: DOE5820.2A Chapter III, Section 3.m(2)}

"Waste Manifest. Records shall be kept and accompany each waste package from generator through final disposal. The manifest shall contain data necessary to document the proper classification, and assist in determining proper treatment, storage, and disposal of the waste. Waste manifests will be kept as permanent records. At a minimum, the following data will be included:

(a) Waste physical and chemical characteristics,

(b) Quantity of each major radionuclide present,

(c) Weight of the waste (total of waste and any solidification or absorbent media),

(d) Volume of waste (total of waste and any solidification or absorbent media), and

(e) Other data necessary to demonstrate compliance with waste acceptance criteria."

\section{Hazardous Waste}

This subelement defines the requirements and controls for dangerous wastes treated and stored at the Hanford Tank Farm Facility. This subelement includes the requirements of the Washington Administrative Code applicable to general waste analysis, waste piles, land disposal restrictions, and surface impoundments. The development of procedures and controls is required to manage these waste in accordance to the requirements of Subpart C of RCRA. The Program must establish a written waste analysis plan that describes the approach to a general waste analysis program to test and determine the detailed chemical, physical, and/or biological analysis of the dangerous waste contained in each tank system. The Program must address and follow the land disposal restrictions mandated under RCRA for liquid waste or waste containing free liquids. Programmatic Controls and implementing procedures should address design requirements for surface impoundments and waste piles to prevent any migration of waste out of the containment barriers.

The primary goals of the Program should include the reduction of risk to human health and the environment. Controls should be in place to support the moratorium imposed by DOE which prohibits shipping hazardous waste to commercial waste management facilities until procedures for the determination of the potential radioactive component of that waste approved by DOE. 


\section{REQUIREMENTS IDENTIFICATION DOCUMENT \\ HIGH LEVEL WASTE STORAGE TANK FARMS \\ Environmental Restoration and Waste Management \\ Revision 0}

14.2.4.1 Design Activities

The application of hazardous waste design methodology must be performed in accordance with the following requirements of RCRA.

FACIITY REQUIREMENT SOURCE: WAC-173 Section 303-630 (8)

"630 (8) Special requirements for ignitable or reactive waste.

630 (8) (a) Containers holding reactive waste exhibiting a characteristic specified in WAC 173-303-090 (7)(a)(vi), (vii) or (viii) must be stored in a manner equivalent to the Uniform Fire Code's "American Table of Distances for Storage of Explosives, " Table 77-201, 1979 edition.

630 (8) (b) The owner or operator shall design, operate, and maintain ignitable waste and reactive waste (other than a reactive waste which must meet (a) of this subsection) container storage in a manner equivalent with the Uniform Fire Code. Where no specific standard or requirements are specified in the Uniform Fire Code, or in existing state or local fire codes, applicable sections of the NFPA Pamphlet \# 30, "Flammable and Combustible Liquids Code," shall be used. The owner/operator shall also comply with the requirements of WAC 173-303-395 (1)(d)."

\section{SITE REQUIREMENT SOURCE: WAC-173-303 Section 395(4)}

"Loading and unloading areas. TSD facilities which receive or ship manifested shipments of liquid dangerous waste for treatment, storag" or disposal must provide for and use an area (or areas) for loading and unloading waste shipments, The loading and unloading area(s) must be designed, constructed, operated and maintained to:

395 (4) (a) Contain spills and leaks that might uccur during loading or unloading;

395 (4) (b) Prevent release of dangerous waste or dangerous waste constituents to ground or surface waters;

395 (4) (c) Contain wash waters (if any) resulting from the cleaning of contaminated transport vehicles and load/ unload equipment; and

395 (4) (d) Allow for removal, as soon as possible, of collected wastes resulting from spills, leaks and equipment cleaning (if any) in a manner which assures compliance with (b) of this subsection."

\section{SITE REQUIREMENT SOURCE: WAC-173-303 Section 630(5)(c)}

"A minimum thirty-inch separation is required between aisles of containers holding dangerous waste(s). A row of drums must be no more than two drums wide."

General Waste Analysis

This subelement defines the requirements of evaluating hazardous waste at the Tank Farm by methods of assay, laboratory analysis or process knowledge. Tank Farms should develop a written waste analysis plan for wastes storage in tank systems that are regulated under 40 CFR 


\section{REQUIREMENTS IDENTIFICATION DOCUMENT \\ HIGH LEVEL WASTE STORAGE TANK FARMS \\ Environmental Restoration and Waste Management \\ Rerision 0}

262 and treated via evaporation. The plan must consist of procedures and controls that Tank Farms WM Program will follow during the treatment process. Tank Farms WM Program is responsible for characterizing hazardous waste for acceptability and/or restrictions from the imposed land disposal restrictions under 40 CFR 268.

\section{STTE REQUIREMENT SOURCE: 40CFR265 Section 402}

"Waste analysis and trial tests.

(a) In addition to the waste analysis required by 265.13 , whenever:

(1) A bazardous waste which is substantially different from waste previously treated in a treatment process or equipment at the facility is to be treated in that process or equipment, or

(2) A substantially different process than any previously used at the facility is to be used to chemically treat hazardous waste; the owner or operator must, before treating the different waste or using the different process or equipment:

(i) Conduct waste analyses and trial treatment tests (e.g., bench scale or pilot plant scale tests); or

(ii) Obtain written, documented information on similar treatment of similar waste under similar operating conditions; to show that this proposed treatment will meet all applicable requirements of 265.401 (a) and (b).

[Comment: As required by 265.13 , the waste analysis plan must include analyses needed to comply with 265.405 and 265.406 . As required by 265.73 , the owner or operator must place the results from each waste analysis and trial test, or the documented information, in the operating record of the facility.]"

\section{FACILITY REQUIREMENT SOURCE: 40CFR268.7 Part 268.7.(4)(i)}

"If a generator is managing a prohibited waste in tanks or containers regulated under 40 CFR 262.34, and is treating such waste in such tanks or containers to meet applicable treatment standards under Subpart D of this part, the generator must develop and follow a written waste analysis plan which describes the procedures the generator will carry out to comply with the treatment standards. The plan must be kept on-site in the generator's records, and the following requirements must be met:

(i) The waste analysis plan must be based on a detailed chemical and physical analysis of a representative sample of the prohibited waste(s) being treated, and contain all information necessary to treat the waste(s) in accordance with the requirements of this Part, including the selected frequency."

\section{FACILITY REQUIREMENT SOURCE: 40CFR268.7 Part 268.7.(a)}

"Except as specified in $\mathbf{2 6 8 . 3 2}$ or section $\mathbf{2 6 8 . 4 2}$ of this part, the generator must test his waste, or test an extract developed using the test method described in Appendix I of this part, or use knowledge of the waste, to determine if the waste is restricted from land disposal under this part." 


\section{REQUIREMENTS IDENTIFICATION DOCUMENT HIGH LEVEL WASTE STORAGE TANK FARMS Environmental Restoration and Waste Management Revision 0}

\section{SITE REQUIREMENT SOURCE: WAC-173-303 Section 070(2)}

"070 (2) (a) Once a material has been determined to be a dangerous waste, then any solid waste generated from the recycling, treatment, storage, or disposal of that dangerous waste is a dangerous waste unless and until:

070 (2) (i) The generator has been able to accurately describe the variability or uniformity of the waste over time, and has been able to obtain demonstration samples which are representative of the waste's variability or uniformity; and

070 (2) (ii)

070 (2) (A) It does not exhibit any of the characteristics of WAC 173-303-090; and

070 (2) (B) If it was a listed waste under WAC 173-303-080 through 173-303-083, it also has been exempted pursuant to WAC 173-303-910(3); or

070 (2) (iii) If originally designated only through WAC 173-303-084 or 173-303-101 through 173-303-103, does not exhibit any of the criteria of WAC 173-303-101 through 173-303-103.

Such solid waste shall include but not be limited to any sludge, spill residue, ash emission control dust, leachate, or precipitation run-off. Precipitation run-off will not be considered a dangerous waste if it can be shown that the run-off has not been contaminated with the dangerous waste, or that the run-off is adequately addressed under existing state laws (e.g. chapter $90.48 \mathrm{RCW}$ ), or that the run-off does not exhibit any of the criteria or characteristics described in WAC 173-303-100.

070 (2) (b) Materials that are reclaimed from solid wastes and that are used beneficially (as provided in WAC 173-303-016 and 173-303-017) are not solid wastes and hence are not dangerous wastes under this section unless the reclaimed material is bumed for energy recovery or used in a manner constituting disposal."

\section{SITE REQUIREMENT SOURCE: WAC-173-303 Section 070(3)}

"Designation procedures.

070 (3) (a) To determine whether or not his waste is designated a person shall check his waste against the following sections, and in the following order:

070 (3) (i) First, Discarded chemical products, WAC 173-303-081;

070 (3) (ii) Second, Dangerous waste sources, WAC 173-303-082;

070 (3) (iii) Third, Infectious dangerous wastes, WAC 173-303-483;

070 (3) (iv) Fourth, Dangerous waste mixtures, WAC 173-303-084; and

070 (3) (v) Last, Dangerous waste characteristics, WAC 173-303-090.

070 (3) (b) In addition to the designation procedures specified in (a) of this subsection, a person may choose or may be required under subsection (4) of this section to check his waste against the following sections, and in the following order: 


\section{REQUIREMENTS IDENTIFICATION DOCUMENT HIGH LEVEL WASTE STORAGE TANK FARMS \\ Environmental Restoration and Waste Management}

\section{Revision 0}

070 (3) (i) First, Toxic dangerous wastes, WAC 173-303-101;

070 (3) (ii) Second, Persistent dangerous wastes, WAC 173-303-102;

070 (3) (iii) Last, Carcinogenic dangerous wastes, WAC 173-303-103.

070 (3) (c) A person shall check each section, in the order set forth, until he determines that his waste is designated. Once his waste is designated through the lists, mixtures or characteristics, be need not determine any other designations for his waste, except as required by subsection (4) or (5) of this section. For the purposes of designating through the criteria, if a person determines that his waste is designated DW, then he must assure that it is not also EWW by checking it against the remaining sections. If the designation procedures identify a waste as both EHW and DW (e.g., a waste may be DW for corrosivity and EHW for EP toxicity), the waste must be designated EHW. If a person has checked his waste against each section that be is required by this section to check and his waste is not designated, then his waste is not subject to the requirements of chapter 173-303 WAC.

Any person y ao wishes to seek an exemption for a waste which has been designated DW or EHW shall comply with the requirements of WAC 173-303-072."

\section{SITE REQUTREMENT SOURCE: WAC-173-303 Section 070(6)}

"Dangerous waste numbers. When a person is reporting or keeping records on a dangerous waste, he shall use all the dangerous waste numbers which he knows are assignable to his waste from the dangerous waste lists, characteristics, or criteria. For example, if his waste is ignitable and contains extremely hazardous concentrations of halogenated hydrocarbons, he shall use the dangerous waste numbers of D001 and WP01. This shall not be construed as requiring a person to designate his waste beyond those designation requirements set forth in subsections (2), (3), (4), and (5) of this section."

\section{SITE REQUIREMENT SOURCE: WAC-173-303 Section 082}

"Dangerous waste sources.

082 (1) The dangerous waste sources list appears in WAC 173-303-9904. Any waste which is listed or which is a residue from the management of a waste listed on the dangerous waste sources list shall be designated a dangerous waste, and shall be identified as DW, except that WAC 173-303-9904 includes several footnotes describing circumstances under which certain dangerous waste sources should be designated EHW rather than DW.

082 (2) Quantity exclusion limit. A person whose waste is listed in WAC 173-303-9904 (including residues from the management of such wastes) shall be a dangerous waste generator (and may not be considered a small quantity generator as provided in WAC 173-303-070(8)) if the amount of his waste exceeds the following quantity exclusion limits:

082 (2) (a) $2.2 \mathrm{lbs}$. (1 kg) per month or per batch for wastes listed with the dangerous waste numbers F020, F021, F022, F023, F026, or F027. For the purposes of this chapter, the term "acutely hazardous waste" shall include dangerous waste sources F020, F021, F022, F023, F026, and F027;

082 (2) (b) $220 \mathrm{lbs}$. (100 kg) per month or per batch of any residue or contaminated soil, waste or other debris resulting from the cleanup of a spill, into or on any land or water of a 


\section{REQUIREMENTS IDENTIFICATION DOCUMENT \\ HIGH LEVEL WASTE STORAGE TANK FARMS \\ Environmental Restoration and Waste Management \\ Revision 0}

waste listed in (a) of this subsection; or

082 (2) (c) 220 lbs. (100 kg) per month or per batch for all other wastes.

082 (3) Care should be taken in the proper designation of these wastes and of mixtures of these wastes and solid wastes. If a person mixes a solid waste with a waste that would be designated as a dangerous waste source under this section, then the entire mixture shall be designated as a dangerous waste source. The mixture shall have the same designation (DW or EHW), and shall have the same dangerous waste number as the dangerous waste source which was mixed with the solid waste.

082 (4) For the purposes of this section, any dangerous waste source listed in WAC 173-303-9904 which lists more than one chemical compound must be designated as a dangerous waste if it contains any one or any combination of the listed chemical compounds. For example, a spent nonhalogenated solvent containing both xylene and acetone must be designated as dangerous waste source F003.

\section{SITE REQUIREMENT SOURCE: WAC-173-303 Section 084}

"Dangerous waste mixtures. 084 (1) Purpose. It is the purpose of this section to describe the means for designating a waste mixture containing dangerous wastes which are not listed in WAC 173-303-081 through 173-303-083.

084 (2) References. The National Institute for Occupational Safety and Health's (NIOSH) Registry of Toxic Effects of Chemical Substances (Registry) is adopted by reference. The table in the United States EPA's regulations 40 CFR Table 302.4 (Spill Table) is adopted by reference.

084 (3) Waste mixture defined. For the purposes of this section, a waste mixture shall be any waste about which some or all of its constituents and concentrations are known, and which has not been designated as:

084 (3) (a) A discarded chemical product under WAC 173-303-081;

084 (3) (b) A dangerous waste source under WAC 173-303-082;

084 (3) (c) An infectious dangerous waste under WAC 173-303-083; or

084 (3) (d) A dangerous waste that has been designated by the criteria of WAC 173-303-101 through 173-303-103.

084 (4) A person who has a waste mixture shall use data which is available to him, and, when such data is inadequate for the purposes of this section, shall refer to the NIOSH Registry and/or to the EPA Spill Table to determine:

084 (4) (a) Toxicity data or category for each known constituent in his waste;

084 (4) (b) Whether or not each known constituent of his waste is a halogenated hydrocarbon or a polycyclic aromatic hydrocarbon with greater than three rings and less than seven rings; and,

084 (4) (c) Whether or not each known constituent of his waste is an International Agency for 


\section{REQUIREMENTS IDENTIFICATION DOCUMENT HIGH LEVEL WASTE STORAGE TANK FARMS \\ Environmental Restoration and Waste Management Revision 0}

Research on Cancer (IARC) buman or animal, positive or suspected carcinogen.

084 (5) Toxicity.

084 (5) (a) If a person has toxic constituents in his waste, he shall determine the toxic category for each known toxic constituent. The toxic category for each constituent may be determined directly from EPA'S Spill Table, or by obtaining data from the NIOSH Registry and checking this data against the toxic category table, below. If data is available for more than one of the four toxicity criteria (aquatic, oral, inhalation, or dermal), then the data of severest toxicity shall be used, and the most acutely toxic category shall be assigned to the constituent. If EPA's Spill Table and the NIOSH Registry do not agree on the same category, then the category arrived at using the NIOSH Registry will take precedence. If toxicity data for a constituent cannot be found in EPA'S Spill Table, NIOSH Registry, or other source reasonably available to a person, then he need not determine the toxic category for that constituent."

\section{SITE REQUIREMENT SOURCE: WAC-173-303 Section 090(2)}

"Dangerous waste characteristics.

090 (2) Representative samples. The department will consider a sample obtained using any of the applicable sampling methods described in WAC 173-303-110(2), sampling and testing methods, to be a representative sample."

\section{SITE REQUIREMENT SOURCE: WAC-173-303 Section 090(3)}

"Dangerous waste characteristics.

090 (3) Equivalent test methods. The testing methods specified in this section shall be the only acceptable methods, uniess the department approves an equivalent test method in accordance with WAC 173-303-910(2)."

\section{SITE REQUIREMENT SOURCE: WAC-173-303 Section 090(4)}

"Dangerous waste characteristics.

090 (4) Quantity exclusion limit. A solid waste is a dangerous waste if it exhibits one or more of the dangerous waste characteristics described in subsections (5), (6), (7), and (8) of this section. If a person's solid waste exhibits one or more of these characteristics, then he shall be a dangerous waste generator (and may not be considered a small quantity generator as provided in WAC 173-303-07O(8)) if the quantity of his waste exceeds 220 lbs. (100 kg) per month or per batch."

\section{SITE REQUIREMENT SOURCE: WAC-173-303 Section 090(5)}

"Dangerous waste characteristics.

090 (5) Characteristic of ignitability.

090 (5) (a) A solid waste exhibits the characteristic of ignitability if a representative sample of the waste has any of the following properties: 


\section{REQUIREMENTS IDENTIFICATION DOCUMENT \\ HIGH LEVEL WASTE STORAGE TANK FARMS \\ Environmental Restoration and Waste Management \\ Rerision 0}

090 (5) (i) It is a liquid, other than an aqueous solution containing less than 24 percent alcohol by volume, and has a flash point less than 60 degrees $C$ ( 140 degrees $F$ ), as determined by a Pensky-Martens Closed Cup Tester, using the test method specified in ASTM Standard D 93-79 or D-93-80, or a Setaflash Closed Cup Tester, using the test method specified in ASTM Standard D-3278-78;

090 (5) (ii) It is not a liquid and is capable, under standard temperature and pressure, of causing fire through friction, absorption of moisture or spontaneous chemical changes and, when ignited, burns so vigorously and persistently that it creates a hazard;

090 (5) (iii) It is an ignitable compressed gas as defined in 49 CFR 173.300 and as determined by the test methods described in that regulation; or,

090 (5) (iv) It is an oxidizer as defined in 49 CFR 173.151.

090 (5) (b) A solid waste that exhibits the characteristic of ignitability, but is not designated as a dangerous waste under any of the dangerous waste lists, WAC 173-303-080 through 173-303-084, or dangerous waste criteria, WAC 173-303-101 through 173-303-103, shall be designated DW, and shall be assigned the dangerous waste number of D001."

SITE REQUIREMENT SOURCE: WAC-173-303 Section 090(0)

"Dangerous waste characteristics.

090 (6) Characteristic of corrosivity.

090 (6) (a) A solid waste exhibits the characteristic of corrosivity if a representative sample of the waste has any one or more of the following properties:

090 (6) (i) It is aqueous, and has a pH less than or equal to 2, or greater than or equal to 12.5, as determined by a pH meter using Method 5.2 in Test Methods for the Evaluation of Solid Waste, Physical/Chemical Methods, available from the department;

090 (6) (ii) It is liquid, and corrodes steel (SAE 1020) at a rate greater than 0.250 inch (6.35 $\mathrm{mm}$ ) per year at a test temperature of 55 degrees $C$ (130 degrees F) as determined by the test method specified in NACE (National Association of Corrosion Engineers) Standard TM-01-69 as standardized in Test Methods for the Evaluation of Solid Waste, Physical/Chemical Methods. The NACE Standard is available from the department; or

090 (6) (iii) It is solid or semi-solid, and when mixed with an equal weight of water results in a solution, the liquid portion of which has the property specified in (a)(i) of this subsection. Procedures for preparing and extracting the solution and liquid are described in the test procedures of WAC 173-303-110(3)(a).

090 (6) (b) A solid waste that exhibits the characteristic of corrosivity, but is not designated as a dangerous waste under any of the dangerous waste lists, WAC 173-303-080 through 173-303-084, or dangerous waste criteria, WAC 173-303-101 through 173-303-103, shall be designated DW, and shall be assigned the dangerous waste number of D002." 


\section{REQUIREMENTS IDENTIFICATION DOCUMENT \\ HIGH LEVEL WASTE STORAGE TANK FARMS \\ Environmental Restoration and Waste Management \\ Revision 0}

\section{SITE REQUIREMENT SOURCE: WAC-173-303 Section 090(7)}

"Dangerous waste characteristics.

090 (7) Characteristic of reactivity.

090 (7) (a) A solid waste exhibits the characteristic of reactivity if a representative sample of the waste has any of the following properties:

090 (7) (i) It is normally unstable and readily undergoes violent change without detonating;

090 (7) (ii) It reacts violently with water;

090 (7) (iii) It forms potentially explosive mixtures with water;

090 (7) (iv) When mixed with water, it generates toxic gases, vapors or fumes in a quantity sufficient to present a danger to human health or the environment;

090 (7) (v) It is a cyanide or sulfide bearing waste which, when exposed to $\mathrm{pH}$ conditions between 2 and 12.5 can generate toxic gases, vapors or fumes in a quantity sufficient to present a danger to human health or the environment;

090 (7) (vi) It is capable of detonation or explosive reaction if it is subjected to a strong initiating source or if heated under confinement;

090 (7) (vii) It is readily capable of detonation or explosive decomposition or reaction at standard temperature and pressure; or

090 (7) (viii) It is a forbidden explosive as defined in 49 CFR 173.51, or a Class A explosive as defined in 49 CFR 173.53, or a Class B explosive as defined in 49 CFR 173.88.

A solid waste that exhibits the characteristic of reactivity, but is not designated as a dangerous waste under any of the dangerous waste lists, WAC 173-303-080 through 173-303-084, or dangerous waste criteria, WAC 173-303-101 through 173-303-103, shall be designated DW, and shall be assigned the dangerous waste number of D003."

\section{SITE REQUIREMENT SOURCE: WAC-173-303 Section 090(8)}

"Dangerous waste characteristics.

090 (8) Toxicity Characteristic.

090 (8) (a) A solid waste exhibits the Toxicity Characteristic if, using the Toxicity Characteristic Leaching Procedure (TCLP, found in Appendix II of 40 CFR Part 261 or available upon request from the department) or equivalent methods approved by the department under WAC 173-303-110(5), the extract from a representative sample of the waste contains any of the contaminants listed in the Toxicity Characteristic List in (c) of this subsection, at concentrations equal to or greater than the respective value given in the list. When the waste contains less than 0.5 percent filterable solids, the waste itself, after filtering using the methodology outlined in the TCLP, is considered to be the extract for the purposes of this subsection. 


\section{REQUIREMENTS IDENTIFICATION DOCUMENT HIGH LEVEL WASTE STORAGE TANK FARMS \\ Environmental Restoration and Waste Management \\ Revision 0}

090 (8) (b) A solid waste that exhibits the characteristic of Toxicity Characteristic, but is not designated as a dangerous waste under any of the dangerous waste lists, WAC 173-303-080 through 173-303-084, or dangerous waste criteria, WAC 173-303-101 through 173-303-103, has the dangerous waste number specified in the list which corresponds to the toxic contaminant causing it to be dangerous.

090 (8) (c) Toxicity Characteristic List. Two levels of concentration are established for the contaminants listed. Any waste containing one or more contaminants with concentrations at or above the EHW threshold shall cause that waste to be designated EHW. Any waste containing contaminants which occur at concentrations at or above the DW threshold only (i.e., no EHW contaminants), shall be designated DW.

\section{TOXICITY CHARACTERISTICS LIST}

Maximum Concentration of Contaminants for the Toxicity Characteristic Dangerous (Chemical Waste Abstracts FHW DW

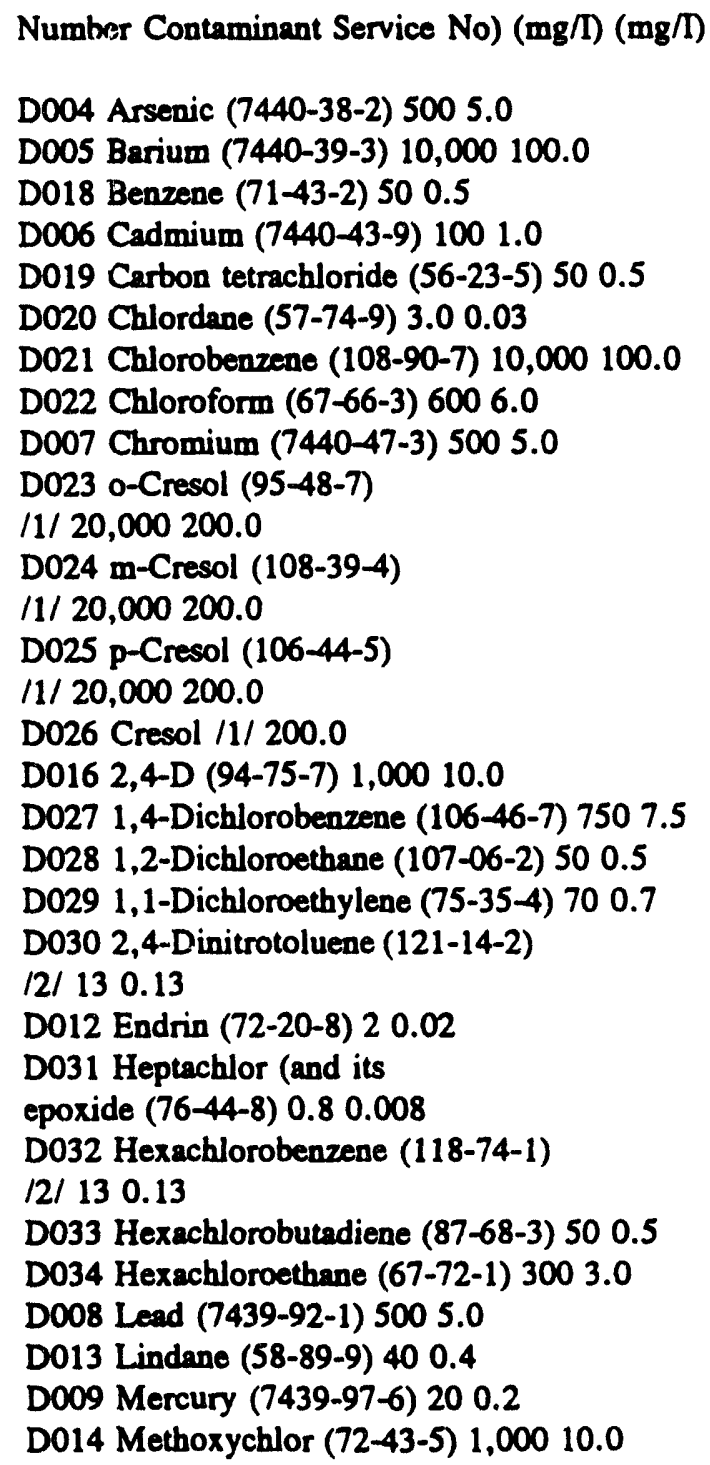




\section{REQUIREMENTS IDENTIFICATION DOCUMENT \\ HIGH LEVEL WASTE STORAGE TANK FARMS \\ Environmental Restoration and Waste Management}

\section{Revision 0}

D035 Methyl ethyl ketone (78-93-3) 20,000 200.0

D036 Nitrobenzene (98-95-3) 2002.0

D037 Peatachlorophenol (87-86-5) $10,000100.0$

D038 Pyridine (110-86-1)

$12 / 5005.0$

D010 Selenium (7782-49-2) 1001.0

D011 Silver $(7440-22-4) 5005.0$

D039 Tetrachloroethylene (127-18-4) 700.7

D015 Toxaphene (8001-35-2) 500.5

D040 Trichloroethyleae $(75-01-6) 500.5$

D041 2,4,5-Trichlorophenol (95-95-4) 40,000 400.0

D042. 2,4,6-Trichlorophenol (88-06-2) 2002.0

D017 2,4,5-TP Silvex (93-72-1) 1001.0

D043 Vinyl chloride $(75-01-4) 200.2$

/1/ If 0-,m-, and p-Cresol concentrations cannot be differentiated, the total cresol (D026) concentration is used. The DW level for total cresol is $200 \mathrm{mg} / \mathrm{L}$ and the EHW lovel for total cresol is $20,000 \mathrm{mg} / \mathrm{L}$

$12 /$ Quantitation limit is greater than the calculated regulatory level. The quantitation limit therefore becomes the regulatory level.

\section{SITE REQUIREMENT SOURCE: WAC-173-303 Section 100}

"Dangerous waste criteria.

100 (1) The dangerous waste criteria consist of:

100 (1) (a) Toxic dangerous wastes, WAC 173-303-101;

100 (1) (b) Persistent dangerous wastes, WAC 173-303-102;

100 (1) (c) Carcinogenic dangerous wastes, WAC 173-303-103; and

100 (1) (d) Dangerous waste characteristics, WAC 173-303-090.

100 (2) Applicability. Any person who has established that his waste meets any of the dangerous waste criteria is a dangerous waste generator, and shall comply with the applicable requirements set forth in this chapter. A person shall use the dangerous waste criteria to designate his waste pursuant to WAC 173-303-070 (3)(b), or (4), or to exempt his waste pursuant to WAC 173-303-072, or to otherwise establish the risk which his waste presents to public bealth and the environment.

\section{SITE REQUIREMENT SOURCE: WAC-173-303 Section 101}

"Toxic dangerous wastes.

101 (1) Purpose. This section describes methods for determining the toxicity of a waste and the criteria by which a toxic waste shall be designated DW or EHW.

101 (2) Categorization. 


\section{REQUIREMENTS IDENTIFICATION DOCUMENT HIGH LEVEL WASTE STORAGE TANK FARMS \\ Environmental Restoration and Waste Management Rerision 0}

101 (2) (a) The following toxic category table establishes categories (X, A, B, C, or D) for particular toxicity levels. The $X$ category is the most toxic, and the $D$ category is least toxic. Substances which have toxicity levels below the D catogory are generally considered to be nontoxic.

\section{TOXIC CATEGORY TABLE}

TLm96 (Fish) or Inhalation

Aquatic (Fish) Oral (Rat) (Rat) Dermal (Rabbit)

Category LCSO(ppm) LDSO(mg/kg) LCSO(mg/L) LDSO (mg/kg)

$X<.1<.5<.02<2$

A .1-15-5.02-.22-20

B $1-105-50.2-220-200$

C $10-10050-5002-20200-2000$

D $100 \cdot 1000500-500020-2002000 \cdot 20,000$

101 (2) (b) In order to determine the toxic categories for the constituents in his waste, a person must obtain toxicity data on the constituents either through knowledge he has about his waste, or by obtaining data from the two sources referenced in subsection (3)(a) and (b) of this section, (EPA's Spill Table and NIOSH Registry). If data obtained for a constituent is available for more than one of the toxicity criteria (aquatic, oral, inhalation, or dermal), then the data of severest toxicity shall be used to assign the most acutely toxic category to the waste constituent.

101 (3) Establishing waste toxicity. A person shall establish the toxicity of his waste or waste constituents by applying his knowledge about his waste, or hy using the following information sources or testing methods, or all of these:

101 (3) (a) The National Institute for Occupational Safety and Health (NIOSH) document Registry of Toxic Effects of Chemical Substances (Registry);

101 (3) (b) The United States EPA's regulation 40 CFR Table 302.4 (Spill Table); and

101 (3) (c) The bioassay testing methods adopted under WAC 173-303-110(3).

101 (4) Book designation procedure.

101 (4) (a) A person may use the book designation procedure described in this paragraph only if:

101 (4) (i) Ho knows the toxic categories (as set forth in subsection (2) of this section) for the significant toxic constituents in his waste;

101 (4) (ii) He knows the concentrations of the significant toxic constituents in his waste; and

101 (4) (iii) He can demonstrate to the department beyond a reasonable doubt that any waste constituents about which he has limited or no knowledge do not significantly affect the toxicity of his waste. 


\section{REQUIREMENTS IDENTIFICATION DOCUMENT \\ HIGH LEVEL WASTE STORAGE TANK FARMS \\ Environmental Restoration and Waste Management \\ Revision 0}

101 (4) (b) Equivalent concentration. A person who is book designating his wasto shall determine the equivalent concentration (in percent) of the toxic constituents in his waste by using the following formula:

Equivalent Concentration $(\%)=\Sigma X \%+\Sigma A \%+\Sigma B \%+\Sigma C \%+\Sigma E D \%$

$\overline{10100100010,000}$

where $\Sigma(X, A, B, C$, or $D) \%$ is the sum of all the concentration percentages for a particular toxic category.

Examplo 1. A person's waste contains: Aldrin (X Category) - .01\%; Diuron (B Category) 1\%; Benzene (C Category) - 4\%; Phenol (C Category) - 2\%; Cyclobexane (C Category) - 5\%; Water (nontoxic) - 87\%. His equivalent concentration (E.C.) would be:

E.C. $(\%)-.01 \%+0 \%+1 \%+(4 \%+2 \%+5 \%)+0 \%$

$\overline{101001000 \overline{10,000}}$

$.01 \%+0 \%+.01 \%+.011 \%+0 \%=.031 \%$

So his equivalent concentration equals .031\%.

101 (4) (c) Toxic dangerous waste graph. To book designate his waste, a person shall use the toxic dangerous waste mix ures graph in WAC 173-303-9906, by finding the equivaleat concentration percentage for his waste along the abscissa, finding his total waste quantity along the ordinate, and plotting the point on the graph where the horizontal line drawn from his total waste quantity intersects the vertical line drawn from his waste mixture's equivalent concentration. If the plotted point is in the area marked DW, he shall designate his waste DW; if the plotted point is in the area marked EHW, he shall designate his waste EHW.

101 (5) Designation from bioassay data. If a person has established the toxicity of his waste by means of the bioassay test methods adopted under WAC 173-303-110(3), and has determinod his waste's toxicity range (C category or greater toxicity, or D category toxicity), then he shall designate his waste according to the toxic dangerous waste designation table, below.

\section{TOXIC DANGEROUS WASTE DESIGNATION TABLE}

If your waste's And your monthly toxic range falls or batch waste Then your waste's in the . . . quantity is ... designation is . . D Category Greater than DW 220 lbs. (100 kg)

$\mathrm{X}, \mathrm{A}, \mathrm{B}$, or $40-220 \mathrm{lbs}$. DW

C Category $(18.2-100 \mathrm{~kg})$

Greater than $220 \mathrm{lbs}$. (100 kg) EHW

STTE REQUREMENT SOURCE: WAC-173-303 Section 102

"Persistent dangerous wastes.

102 (1) Purpose. This section describes the procedures for designating wastes which contain halogenated hydrocarbons $(\mathrm{HH})$ and/or polycyclic aromatic hydrocarbons with more than three rings and less than seven rings (PAH). 


\section{REQUIREMENTS IDENTIFICATION DOCUMENT HIGH LEVEL WASTE STORAGE TANK FARMS \\ Environmental Restoration and Waste Management \\ Revision 0}

102 (2) Concentration determination. A person shall determine the concentration of HIH and/or PAH in his waste by either leating his wasto as specified in (a) of this subsection, or by the calculation procedures described in (b) of this subsection.

102 (2) (a) Concentration tests. A person shall test his waste to determine its concentration lovel as follows:

102 (2) (i) For HH - By using the teating mothods specified in WAC 173-303-110 (3)(a)(v); and,

102 (2) (ii) For PAH - By using the testing methods specified in WAC 173-303-110 (3)(a)(vi).

102 (2) (b) Concentration calculations. If a pereon knows the concentrations of the significant persistent constituents in his waste, and if he can demonstrato to the department beyond a ressonable doubt that any remaining persistent constituents for which he does not know the concentrations would not contribute significantly to the total persistent concentration, then be may calculate the concentration of persistent constituents in his waste as follows:

102 (2) (i) A person whose waste contains one or more halogenated hydrocarbons for which the concentrations are known shall determine his total halogenated hydrocarbon concentration by summing the concentration percentages for all of his waste's significant halogenated hydrocarbons. Examplo 1. A person's waste contains: Carbon tetrachloride - .009\%; DDT $.012 \% ; 1,1,1$ - trichloroethylene - .02\%. His total balogenated hydro carbon concentration would be:

Total HH Concentration $(\%)=.009 \%+.012 \%+.02 \%=.041 \%$

102 (2) (ii) A person whose waste contains one or more polycyclic aromatic bydrocarbons with more than three rings and less than seven rings for which the concentrations are known shall determine his total polycyclic aromatic hydrocarbon concentration by summing the concentration percentages for all of his waste's significant polycyclic aromatic hydrocarbons with more than three rings and less than seven rings.

Example 2. A person's waste contains: Chrysene $.08 \% ; 3,4$ - benzopyrene - $1.22 \%$. His total polycyclic aromatic hydrocarbon concentration would be:

Total PAH Concentration $(\%)=.08 \%+1.22 \%=1.3 \%$

102 (3) Designation criteria and quantity. A person whose waste contains persistent (HH or PAH) constituents shall designate his waste according to the persistent dangerous waste table, below, if his monthly or batch waste quantity exceeds $220 \mathrm{lbs}$. (100 kg).

\section{PERSISTENT DANGEROUS WASTE TABLE}

If your wasto At a concentration Then your waste's contains. . . level of. . . designation is. . .

Halogenated

0.01 to $1.0 \% \mathrm{DW}$

Hydrocarbons (HI]) greater than 1.0\% EHW

Polycyclic Aromatic greater than 1.0\% EHW*

Hydrocarbons (PAH) 


\section{REQUIREMENTS IDENTIFICATION DOCUMENT HIGH LEVEL WASTE STORAGE TANK FARMS \\ Environmental Restoration and Waste Management Revision 0}

- No DW concentration lovel for PAH.

\section{SITE REQUIREMENT SOURCE: WAC-173-303 Section 103}

"Carcinogenic dangerous weates.

103 (1) Criteria. A substance which is listed in the National Institute for Occupational Safety and Health (NIOSH) documeat Registry of Toxic Effocts of Chemical Substances (Registry), or any other scientific or technical documents, as IARC (International Agency for Recearch on Cancer) bumen or animal, sufficieat or limited carcinogen, shall be a carcinogenic substance for the purposes of this section. Any LARC identified substance which is an inorganic, respiratory carcinogen shall be a carcinogenic substance only if it occurs in a friable format (i.e., if it is in a waste which canily crumbles and forms dust which can be inhaled).

103 (2) Designation. Any person whose wasto contains one or more IARC carcinogen(8) shall designate his wasto if:

103 (2) (a) The monthly or batch waste quantity exceeds $220 \mathrm{lbs}$. (100 kg); and either

103 (2) (b)

103 (b) (i) The concentration of any one IARC sufficient (human or animal) carcinogen exceods $1.0 \%$ of the waste quantity. Such waste shall be designated EHW, and such designation shall take precedence over any DW designation determined by (b) (ii) or (iii) of this subsection; or

103 (b) (ii) The concentration of any one IARC sufficient (human or animal) carcinogen exceeds $0.01 \%$ of the waste quantity. Such waste shall be designated DW; or

103 (b) (iii) The total concentration summed for all IARC sufficient and limited (humen and animal) carcinogens exceeds $1.0 \%$ of the waste quantity. Such waste shall be desigaated DW.

103 (c) For desigaation purposes, any IARC buman or animal, sufficient or limited carcinogen that is so rated because of studies involving implantation of the substance into test animals as sole cause for the IARC rating, shall not be carcinogenic. This additional information is available in the IARC Monographs on the Evaluation of the Carcinogenic Risk of Chemicals to Humans.

\section{SITE REQUIREMENT SOURCE: WAC-173-303 Section 104}

-Generic dangerous waste numbers.

104 (1) Purpose. This section sets forth the dangerous wasto number for each of the dangerous waste criteria designations.

104 (2) Characteristics. A waste which exhibits any of the dangerous waste characteristics, WAC 173-303-090, shall be assigned the dangerous waste number corresponding to the characteristic(s) exhibited by the wasto.

104 (3) Criteria. The following table shall be used for assigning dangerous waste numbers to wastes designated by the dangerous waste criteria or by WAC 173-303-084. 


\section{REQUIREMENTS IDENTIFICATION DOCUMENT \\ HIGE LEVEL WASTE STORAGE TANK FARMS \\ Environmental Restoration and Waste Management \\ Revision 0}

\section{GENERIC DANOEROUS WASTE NUMBERS TABLE}

Dangerous

Waste No. Dangerous Waste Criteria and Designation

Toxic Dengerous Wastes

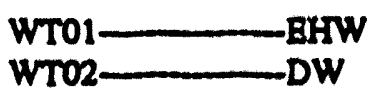

Perdiateat Dangerous Wastes

Halogenated Hydrocarbons

WPO1- EHW

WPO2-DW

Polycyclic Aromatic Hydrocarbons

WPO3-EHW

Carcinogenic Dangerous Wastes

WCO1_ EHW

WCO2-DW

\section{SITE REQUTREMENT SOURCE: WAC-173-303 Section 110}

"Sampling and teoting methods.

110 (1) Purpose. This section describes the testing methods which may be used in the process of desigmating a dangerous wasto.

110 (2) Representative samples.

110 (2) (a) The metbods and equipment used for obtaining representative samples of a waste will vary with the type and form of the waste. The departmont will consider samples collected using the ampling methods below, for wastes with properties similar to the indicated materials, to be representative samples of the wastes:

110 (2) (i) Crushed or powdered material - ASTM Standard D346-75;

110 (2) (ii) Extremoly viscous liquid - ASTM Standard D140-70;

110 (2) (iii) Fly ash-like material - ASTM Standard D2234-86;

110 (2) (iv) Soil-like matorial - ASTM Standard D1452-65;

110 (2) (v) Soil or rock-like material - ASTM Standard D420-69;

110 (2) (vi) Containerized liquid wastes - "COLIWASA" described in Test Methods for the Evaluation of Solid Waste, Physical/Chemical Methods, SW-846, revised July 1982, as ameaded by Update 1 (April 1984) and Update 2 (April 1985); and,

110 (2) (vii) Liquid waste in pits, ponds, lagoons, and similar reservoirs - "Pond Sampler" described in Test Methods for the Evaluation of Solid Waste, Physical/Chemical Methods, SW-846, revisod July 1982, as amended by Updato 1 (April 1984) and Update 2 (April 1985).

110 (2) (b) Copies of these representative sampling methods are available from the department except for the ASTM standards which can be obtained by writing to: 


\section{REQUIREMENTS DENTIFICATION DOCUMENT \\ HIGE LEVEL WASTE STORAGE TANK FARMS \\ Environmental Restoration and Waste Management \\ Revision 0}

ASTM

1916 Race Stroed

Philadolphia, PA 19103.

110 (3) Teet procedures. Copies of the test procedures listed in this subsection can be obtained from the department by writing to the appropriate address below:

For copies of WDOE tent methods:

Atto: Teat Procedures

Hazardous Waste Section, PV-11

Departwent of Ecology

Olympia, Washington 98504

For copies of SW 846:

Superinteadeat of Documents

U.S. Governmeat Printing Office

Weshington, D.C. 20401

For copies of ASTM mothods:

ASTM

1916 Race Street

Philadelphia, PA 19103

The document titles and included test procedures are as follows:

110 (3) (a) Chemical Testing Methods for Complying with the Dangerous Waste Regulation, March 1982, revised July 1983, describing methods for testing:

110 (3) (i) Ignitability;

110 (3) (ii) Corrosivity, including the addendum, Test Method for Determining pH of Solutions in Contact with Solids, March 1984;

110 (3) (iii) Reactivity;

110 (3) (iv) EP Toxicity;

110 (3) (v) Halogenated bydrocarbons; and

110 (3) (vi) Polycyclic aromatic bydrocarbons;

110 (3) (b) Biological Testing Methods, the latest revision, describing procedures for:

110 (3) (i) Static acute fish toxicity tost; and

110 (3) (ii) Acute oral rat toxicity test;

110 (3) (c) Test Methods for Evaluating Solid Waste, Physical/Chemical Methods, SW-846 (the most recent edition and all updates) is adopted by reference. This includes: 


\section{REQUTREMENTS IDENTIFICATION DOCUMENT HIGH LEVEL WASTE STORAGE TANK FARMS \\ Environmental Restoration and Waste Management Revision 0}

110 (3) (i) Method 9095 (Paint Filter Liquids Test), demonstrating the absence or presence of freo liquids in either a containerized or bulk waste;

110 (3) (ii) Reserved;

110 (3) (d) 40 CFR Part 261 Appendix X is adopted by reference for the purpose of analysis for chlorinated dibenzo-p-dioxins and dibenzofurans;

$110(3)(e)$

110 (3) (i) The determination of Polychlorinated Biphenyls in Transformer Fluids and Waste Oils, EPA-600/4-81-045; and

.)

110 (3) (ii) Analysis of Polychlorinated Biphenyls in Mineral Insulating Oils by Gas Chromatography, ASTM Standard D 4059-86.

110 (4) Substantial changes to the testing methods described above shall be made only after the department bas provided adequate opportunity for public review and comment on the proposed changes. The department may, at its discretion, schedule a public hearing on the proposed changes.

110 (5) Equivalent testing methods. Any person may request the department to approve an equivalent testing method by submitting a petition, prepared in accordance with WAC 173-303-910(2), to the department.

\section{FACLITY REQUIREMENT SOURCE: WAC-173-303 Section 300 (2)}

"(2) The owner or operator shall obtain a detailed chemical, physical, and/or biological analysis of a dangerous waste before he stores, treats, or disposes of it. This analysis must contain the information necessary to manage the waste in accordance with the requirements of this chapter 173-303 WAC. The analysis may include or consist of existing published or documented data on the dangerous waste, or on waste generated from similar processes, or data obtained by testing, if necessary."

\section{FACILITY REQUIREMENT SOURCE: WAC-173-303 Section 300 (4)(a)}

"(4) Analysis shall be repeated as necessary to ensure that it is accurate and current. At a minimum, analysis must be repeated: (a) When the owner or operator has been notified, or has reason to believe, that the process or operation generating the dangerous waste has significantly changed."

\section{FACIITY REQUIREMENT SOURCE: WAC-173-303 Section 300 (5)(a-n)}

"(5) Waste analysis plan. The owner or operator shall develop and follow a written waste analysis plan which describes the procedures he will use to comply with the waste analysis requirements of subsections (1), (2), (3), and

(4) of this section. He must keep this plan at the facility, and the plan must contain at least:

(a) The parameters for which each dangerous waste will be analyzed, and the rationale for selecting these parameters; 


\section{REQUIREMENTS IDENTIFICATION DOCUMENT \\ HIGH LEVEL WASTE STORAGE TANK FARMS \\ Environmental Restoration and Waste Management \\ Revision 0}

(b) The methods of obtaining or testing for these parameters;

(c) The methods for obtaining representative samples of wastes for analysis (representative sampling methods are discussed in WAC 173-303-110 (2));

(d) The frequency with which analysis of a waste will be reviewed or repeated to ensure that the analysis is accurato and curreat;

(e) The waste analysis which waste generators bave agreed to supply;

(f) Where applicable, the methods for meeting the additional waste analysis requirements for specific waste management mothods as specified in 40 CFR Part 265 Subparts $F$ through $R$ for interim status facilities and in WAC 173-303-630 through 173-303-670 for final status facilities."

FACILTY REQUIREMENT SOURCE: 40CFR268 Part 268.40 (a)

"A restricted waste identified in 268.41 may be land disposed only if an extract of the waste or of the treatment residue of the wasto developed using the test method in appendix I of this part does not exceed the value shown in Table CCWE of 268.41 for any hazardous constituent listed in Table CCWE for that waste, with the following exceptions: D004, D008, K031, K084, K101, K102, P010, P011, P012, P036, P038, and U136. Wastes D004, D008, K031, K084, K101, K102, P010, P011, P012, P036, P038, and U136 may be land disposed only if an extract of the waste developed using either the test method in Appendix I of this part or the test method in appendix II of part 261 does not exceed the values shown in Table CCW of 268.41 for any hazardous constituent listed in Table CWE for that waste."

\section{FACILITY REQUIREMENT SOURCE: 40CFR268 Part 268.40 (b)}

"A restricted waste for which a treatment technology is specified under 268.42(a) may be land disposed after it is treated using that specified technology or an equivalent treatment method approved by the Administration under the procedures set forth in 268.42 (b)."

FACILITY REQUIREMENT SOURCE: 40CFR268 Part 268.40 (c)

"Except as otherwise specified in 268.43(c), a restricted waste identified in 268.43 may be land disposed only if the constituent concentrations in the waste or treatment residue of the waste do not exceed the value shown in Table CCW of 268.43 for any hazardous constituents listed in Table CCW for that waste."

\section{FACIITY REQUIREMENT SOURCE: WAC-173-303 Section 140 (4)(b)}

"(b) Disposal of liquid waste. Special requirements for the disposal of liquid waste in landfills.

(i) Bulk or noncontainerized liquid waste or waste containing free liquids must not be placed in a landfill uniess, before disposal, the liquid waste or waste containing free liquids is treated so that free liquids are no longer present.

(ii) Containers holding free liquids must not be placed in a landfill unless: 


\section{REQUIREMENTS IDENTIFICATION DOCUMENT \\ HIGH LEVEL WASTE STORAGE TANK FARMS \\ Environmental Restoration and Waste Management \\ Revision 0}

(A) All free-standing liquid:

(I) Has been removed by decanting, or other methods; or

(II) Has been mixed with absorbent or stabilized (solidified) so that free-standing liquid is no longer observed; or

(III) Has been otherwise eliminated; or

(B) The container is very small, such as an ampule; or

(C) The container is a lab pack and is disposed of in accordance with WAC 173-303-161 and this chapter.

(iii) To demonstrate the absence or presence of free liquids in either a containerized or a bulk waste, the following tests must be used: Method 9095 (Paint Filter Liquids Test) as described in Test Methods for Evaluating Solid Wastes, Physical/Chemical Methods. (EPA Publication No. SW-846.)

\section{FACILITY REQUIREMENT SOURCE: WAC-173-303-140 (4)(a)}

"(4)(a) Disposal of extremely hazardous waste (EHW). No person shall land dispose of EHW, except as provided in subsection (5) of this section, at any land disposal facility in the state. No person shall land dispose of EHW at the facility established under RCW 70.105-.050, except as provided by subsections (5), (6), and (7) of this section. A person is encouraged to reciaim, recycle, recover treat, neutralize, or otherwise process EHW to remove or reduce its harmful properties or characteristics, provided that such processing is performed in accordance with the requirements of this chapter."

\section{Surface Impoundments}

This subelement defines the requirements for establishing design, construction and installation protocols for surface impoundments in order to mitigate the migration of dangerous wastes out of the impoundment boundary. Design requirements must adhere to the stringent codes of WAC 173-303-650. Controls must be in place to ensure a leak detection monitoring program is employed and installed to monitor the performance of the impoundments.

\section{FACILITY REQUIREMENT SOURCE: WAC-173-303 Section 140 (5)(a)}

"(5)(a) Surface impoundment trestment.

(i) Liquid waste, extremely hazardous waste (EHW), solid acid waste, leachable inorganic waste, and organic/carbonaceous waste may be placed in surface impoundments for purposes of treatment provided the owner/operator can demonstrate that effective treatment of the dangerous waste constituents will occur and at closure the owner/operator complies with the prohibitions and restrictions of subsection (4) of this section."

\section{FACILITY REQUIREMENT SOURCE: WAC-173-303 Section 650 (2)}

"Design and operating requirements. 


\section{REQUIREMENTS IENTIFICATION DOCUMENT \\ HIGH LEVEL WASTE STORAGE TANK FARMS \\ Environmental Restoration and Waste Management \\ Revision 0}

(a)(i) A surface impoundment (except for an existing portion of a surface impoundment) must have a liner that is designed, constructed, and installed to prevent any migration of wastes out of the impoundment to the adjacent subsurface soil or ground water or surface water at any time during the active life (including the closure period) of the impoundment. The liner may be constructed of materials that may allow waste to migrate into the liner (but not into the adjacent subsurface soil or ground water or surface water) during the active life of the facility, provided that the impoundment is closed in accordance with subsection (6)(a)(i) of this section."

\section{FACIITY REQUIREMENT SOURCE: WAC-173-303 Section 650 (3)(b)}

"If liquid leaks into the leak detection system, the owner or operator must:

(i) Notify the department of the leak in writing within seven days after detecting the leak; and

(ii) (A) Within a period of time specified in the permit, remove accumulated liquid, repair or replace the liner which is leaking to prevent the migration of liquids through the liner, and obtain a certification from a qualified engineer that, to the best of his knowledge and opinion, the leak has been stopped; or

(B) If a detection monitoring program pursuant to WAC 173-303-645(9) has already been established in the permit (to be complied with only if a leak occurs), begin to comply with that program and any other applicable requirements of WAC 173-303-645 within the period of time specified in the permit."

\section{FACILITY REQUIREMENT SOURCE: WAC-173-303 Section 650 (4)}

"(a) During construction and installation, liners (except in the case of existing portions of surface impoundments exempt from subsection (2)(a)(i) of this section) and cover systems (e.g., membranes, sheets, or coatings) must be inspected for uniformity, damage, and imperfections (e.g., holes, cracks, thin spots, or foreign materials). Immediately after construction or installation:

(i) Synthetic liners and covers must be inspected to ensure tight seams and joints and the absence of tears, punctures, or blisters; and

(ii) Soil-based and admixed liners and covers must be inspected for imperfections including lenses, cracks, channels, root holes, or other structural nonuniformities that may cause an increase in the permeability of the liner or cover.

(b) While a surface impoundment is in operation, it must be inspected weekly and after storms to detect evidence of any of the following:

(i) Deterioration, malfunctions, or improper operation of overtopping control systems;

(ii) Sudden drops in the level of the impoundment's contents;

(iii) The presence of liquids in leak detection systems, where installed to comply with subsection (3) of this section; and

(iv) Severe erosion or other signs of deterioration in dikes or other containment devices." 


\section{REQUIREMENTS IDENTIFICATION DOCUMENT HIGH LEVEL WASTE STORAGE TANK FARMS Environmental Restoration and Waste Management Revision 0}

Management of Containers

This subelement defines the management requirements for containers storing dangerous waste. Controls must be developed and implemented that adhere to the provisions of WAC 173-303-640. The WM program is responsible for developing a Tank System Closure Plan that consist of cost estimates of closure and financial responsibility designation. Controls must be employed to identify and label all tank systems to reflect the major risk associated with the content materials. Programmatic controls should be in place that require the implementation of an inspection and monitoring program with the objective of determining the current conditions of the tank (i.e. corrosion, deterioration etc...).

\section{FACIITY REQUIREMENT SOURCE: WAC-173-303 Section 160 Containers .3}

" 160 (1) Waste quantity. Containers and inner liners shall not be considered as a part of the waste when measuring or calculating the quantity of a dangerous waste. Only the weight of the residues in nonempty or nonrinsed containers or inner liners will be considered when determining waste quantities.

160 (2) A container or inner liner is "empty" when:

160 (2) (a) All wastes in it have been taken out that can be removed using practices commonly employed to remove materials from that type of container or inner liner (e.g., pouring, pumping, aspirating, etc.) and, whichever quantity is least, either less than one inch of waste remains at the bottom of the container or inner liner, or the volume of waste remaining in the container or inner liner is equal to one percent or less of the container's total capacity, or, if the container's total capacity is greater than one bundred ten gallons, the volume of waste remaining in the container or inner liner is no more than 0.3 percent of the container's total capacity.

A container which held compressed gas is empty when the pressure inside the container equals or nearly equals atmospheric pressure; and

160 (2) (b) If the container or inner liner held acutely hazardous waste, as defined in WAC 173-303-040, or pesticides bearing the danger or waming label, the container or inner liner has been rinsed at least three times with an appropriate cleaner or solvent. The volume of cleaner or solvent used for each rinsing shall be ten percent or more of the container's or inner liner's capacity. In lieu of rinsing for containers that might be damaged or made unusable by rinsing with liquids (e.g., fiber or cardboard containers without inner liners), an empty container may be vacuum cleaned, struck, with the open end of the container up, three times (e.g., on the ground, with a hammer or hand) to remove or loosen particles from the inner walls and corners, and vacuum cleaned again. Equipment used for the vacuum cleaning of residues from containers or inner liners must be decontaminated before discarding, in accordance with procedures approved by the department.

Any rinsate or vacuumed residue which results from the cleaning of containers or inner liners shall whenever possible be reused in a manner consistent with the original intended purpose of the substance in the container or inner liner. In the case of a farmer, if the rinsate is a pesticide residue then the rinsate shall be managed or reused in a manner consistent with the instructions on the pesticide label, provided that when the label instructions specify disposal or burial, such disposal or burial must be on the farmer's own (including rented, leased or tenanted) property. Otherwise, the rinsate shall be checked against the designation requirements (WAC 173-303-070 through 173-303-103) and, if designated, managed according 


\section{REQUIREMENTS IDENTIFICATION DOCUMENT HIGH LEVEL WASTE STORAGE TANK FARMS Environmental Restoration and Waste Management Revision 0}

to the requirements of this chapter.

160 (3) Any residues remaining in containers or inner liners that are "empty" as described in subsection (2) of this section will not be subject to the requirements of this chapter, and will not be considered as accumulated wastes for the purposes of calculating waste quantities.

160 (4) A person may petition the department to approve alternative container rinsing processes in accordance with WAC 173-303-910(1)."

\section{SITE REQUIREMENT SOURCE: WAC-173-303 Section 200 1(b)}

"Section 200 1(b)

200 (1) (b) The waste is placed in containers and the generator complies with WAC 173-303-630 (2), (3), (4), (5), (6), (8), and (9), or the waste is placed in tanks and the generator complies with WAC 173-303-640 (2) through (10), except WAC 173-303-640 (8)(c) and the second sentence of WAC 173-303-640 (8)(a). (Note: A generator, unless otherwise required to do so, does not have to prepare a closure plan, a cost estimate for closure, or provide financial responsibility for his tank system to satisfy the requirements of this section. In lieu of the "sufficient freeboard" requirement of WAC 173-303-640 (5)(b)(iii) for uncovered tanks, the generator must maintain a minimum freeboard of two feet. Such a generator is exempt from the requirements of WAC 173-303-620 and 173-303-610, except for WAC 173-303-610 (2) and (5). For container accumulation (including satellite areas as described in subsection (2)(c) of this section), the department may require that the accumulation area inclu2e or mixtures, WAC 173-202-084, secondary containment in accordance with WAC 173-303-630(7), if the department determines that there is a potential threat to public health or the environment due to the nature of the wastes being accumulated, or due to a bistory of spills or releases from accumulated containers. In addition, any new container accumulation areas (but not including new satellite areas, unless required by the department) constructed or installed after September 30, 1986, must comply with the provisions of WAC 173-303-630(7);

SITE REQUIREMENT SOURCE: WAC-173-303 Section 395(6)

"Labeling for containers and tanks.

The owner or operator must label containers and tanks in a manner which adequately identifies the major risk(s) associated with the contents for employees, emergency response personnel and the public (Note-If there is already a system in use that performs this function in accordance with local, state or federal regulations, then such system will be adequate). The owner or operator must ensure that labels are not obscured, removed, or otherwise unreadable in the course of inspection required under WAC 173-303-320. For tanks, the label or sign shall be legible at a distance of at least fifty feet. For containers, the owner or operator must affix labels upon transfer of dangerous waste from one container to another. The owner or operator must destroy or otherwise remove labels from the emptied container, unless the container will continue to be used for storing dangerous waste at the facility."

\section{FACILITY REQUIREMENT SOURCE: WAC-173-303 Section 630 (2)}

"(2) Condition of containers. If a container holding dangerous waste is not in good condition (e.g. severe rusting, apparent structural defects) or if it begins to leak, the owner or operator must transfer the dangerous waste from the container to a container that is in good condition or 


\section{REQUIREMENTS IDENTIFICATION DOCUMENT HIGH LEVEL WASTE STORAGE TANK FARMS Environmental Restoration and Waste Management Revision 0}

mange the waste in some other way that complies with the requirements of chapter 173-303 WAC. In addition, the owner or operator must address leaks and spills in accordance with the applicable provisions of WAC 173-303-145 and 173-303-360."

\section{FACILITY REQUIREMENT SOURCE: WAC-173-303 Section 630 (3)}

"(3) Identification of containers. The owner or operator must label in a manner which adequately identifies the major risk(8) associated with the contents of the containers for employees, emergency response personnel and the public (Note- If there is already a system in use that performs this function in accordance with local, state or federal regulations, then such system will be adequate). The owner or operator must destroy or otherwise remove labels from the emptied container, unless the container will continue to be used for storing dangerous waste at the facility. The owner or operator must ensure that labels are not obscured, removed, or otherwise unreadable in the course of inspection required under WAC 173-303-320."

\section{FACILITY REQUREMENT SOURCE: WAC-173-303 Section 630 (4)}

"(4) Compatibility of waste with containers. The owner or operator must use a container made of or lined with materials which will not react with, and are otherwise compatible with, the dangerous waste to be stored, so that the ability of the container to contain the waste is not impaired."

\section{FACILITY REQUIREMENT SOURCE: WAC-173-303 Section 630 (5)(a)}

"5 Management of containers.

(a) A container holding dangerous waste must have always be closed, except when it is necessary to add or remove waste.

\section{FACILITY REQUIREMENT SOURCE: WAC-173-303 Section 630 (6)}

"(6) Inspections. At least weekly, the owner or operator must inspect areas where containers are stored looking for leaking containers and for deterioration of containers and the containment system caused by corrosion, deterioration, or other factors."

\section{FACILTY REQUIREMENT SOURCE: WAC-173-303 Section 630 (7) (d)}

"(d) EHW in containers must be protected from the elements by means of a building or other protective covering that otherwise allows adequate inspection under subsection (6) of this section."

\section{FACILITY REQUIREMENT SOURCE: WAC-173-303 Section 630 (7)(a)}

\section{"(7) Containment}

(a) Container storage areas must have a containment system that is capable of collecting and holding spills and leaks. In addition to the necessary leak containment capacity, uncovered storage areas must be capable of holding the additional volume that would result from the precipitation of a maximum twenty-five year storm of twenty-five hours duration. The cortainment system must: 


\section{REQUIREMENTS IDENTIFICATION DOCUMENT HIGH LEVEL WASTE STORAGE TANK FARMS Environmental Restoration and Waste Management Revision 0}

(i) Have a base underlying the containers which is free of cracks or gaps and is sufficiently impervious to contain leaks, spills, and accumulated rainfall until the collected material is detected and removed. The base must be sloped or the containment system must be otherwise designed and operated to drain and remove liquids resulting from leaks, spills, or precipitation, unless the containers are elevated or are otherwise protected from contact with accumulated liquids.

(ii) Be designed for positively drainage control (such as locked drainage valve) to prevent release of containment liquids; and so that uncontaminated precipitation can be drained promptly for convenience of operation. Spilled or leaked waste and accumulated precipitation must be romoved from the containment system in as timely a manner as is necessary to prevent overflow; and

(iii) Have sufficient capacity to contain ten percent of the volume of all containers or the volume of the largest container, which ever is greater. Only containers holding free liquids, or holding wastes designated as F020, F021, F022, F023, F026, or F027 need to be considered in this determination."

\section{FACILITY REQUIREMENT SOURCE: WAC-173-303 Section 630 (7)(c)}

"(c) Storage areas that store containers holding only wastes that do not contain free liquids, do not exhibit either the characteristics of ignitability or reactivity as described in WAC 173-303-090(5) or (7), and are not designated as F020,F021, F022, F023, F026, or F027 need not have a containment system as described in this subsection: PROVIDED, That:

(i) The storage area is sloped or is otherwise designed and operated to drain and remove liquid resulting from precipitation; or

(ii) The containers are elevated or are otherwise protected from the contact with accumulated liquids."

\subsubsection{Waste Piles}

This subelement defines the necessary waste management controls for installation, maintenance, and operation of waste piles at the Tank Farm Facility. Programmatic controls for managing waste piles must be in accordance with WAC 173-303-660. Mitigation controls to minimize wind dispersal of particulate matter storage materials should be employed in accordance to the provisions of this regulation. WM administrative and engineering controls should be implemented to preclude the mixing of incompatible waste types that consist of inspection programs and barrier controls, respectively.

\section{FACILITY REQUIREMENT SOURCE: WAC-173-303 Section 660 (8)(b)}

"(b) A pile of dangerous waste that is incompatible with any waste or other material stored nearby in other containers, piles, open tarks, or surface impondments must be separated from the other materials, or protected from then by means of a dike, berm, wall, or other device. Piles of incompatible wastes must not be served by the same containment system."

\section{FACILITY REQUIREMENT SOURCE: WAC-173-303 Section 6602 (h)}

"(h) If the pile contains any particulate matter which may be subject to wind dispersal, the 


\section{REQUIREMENTS IDENTIFICATION DOCUMENT \\ HIGH LEVEL WASTE STORAGE TANK FARMS \\ Environmental Restoration and Waste Management \\ Revinion 0}

owner or operntor must cover or otherwise manage the pile to control wind dispersal."

14.2 .4 .7

$14.2,4.8$

\section{Storage Time Limitations}

This subelement defines the storage time limitations in waste piles and impoundments for dangerous wastes imposed by WAC 173-303-295. The Tank Farm Facility should develop and implement controls that define methods for identifying waste types and the segregation of waste of different ages to allow proper management of storage time restraints. Schedules and recordkeeping systems should be doveloped for removing waste from storage to meet the time limitation criteria.

\section{FACILITY REQUIREMENT SOURCE: WAC-173-303 Section 395 (5)(a)}

"Storage time limit for impoundments and piles.

(a) Except as provided in (b) or (c) of this subsection, dangerous waste shall not be stored in a surface impoundment or waste pile for mote than five years after the waste was first placed in the impoundment or pile. For the purposes of this requirement, the five-year limitation, for waste regulated under this chapter and being stored impoundments or piles on the effective date of this requirement, will begin on August 1, 1984. The age of stored wastes must be determined on a monthly basis. The owner/operator of a surface impoundment or waste pile used for storing dangerous waste must develop a written plan, to be kept at the facility, for complying with the five-year storage limit. The plan must describe the operating conditions, waste identification procedures (for keeping track of the age of the waste), and a waste removal schedule, and at a minimum the plan must include the following elements:

(i) Methods for identifying the age of dangerous wastes placed in the impoundment or pile;

(ii) Where practical, procedures for segregating wastes of different ages. If the waste cannot be practically segregated, then the age of all waste place in the impoundment or pile shall be deemed the same age as the oldest waste in the impoundment or pile;

(iii) A schedule for removing dangerous waste from the impoundment or pile, or for disposing of them in a timely manner to assure compliance with the five- year limit;

(iv) A description of the actions to be taken according to the schedule required by (a)(iii) of this subsection;

(v) Procedures for noting in the operating record required by WAC 173-303-380(1) that the requirements of this subsection have been satisfied; and (vi) Such other requirements as the department specifies."

\section{Waste Generation}

This subelement specifies the requirements for generation and accumulation of dangerous waste.

\section{SITE REQUIREMENT SOURCE: WAC-173-303 Section 170 (1)}

" 170 (1) A person shall be a dangerous waste generator if his solid waste is designated by the requirements of WAC 173-303-070 through 173-303-103. 


\section{REQUIREMENTS IDENTIFICATION DOCUMENT FIGH LEVEL WASTE STORAGE TANK FARMS Environmental Restoration and Waste Management Revision 0}

170 (1) (a) The generator ahall be responsible for designating his waste as DW or EHW.

170 (1) (b) The generator may request an exemption for his dangerous waste according to the procedures of WAC 173-303-072."

\section{SITE REQUIREMIENT SOURCE: WAC-173-303 Section 170 (2)}

" 170 (2) A dangerous wasto generutor shall notify the department and obtain an EPA/state identification number as required by WAC 173-303-060, and shall comply with the requirements of WAC 173-303-170 through 173-303-230."

\section{SITE REQUIREMENT SOURCE: WAC-173-303 Section 170 (3)}

" 170 (3) Except for the accumulation and storage of dangerous wastes for less than ninety days as allowed under WAC 173-303-200, sny generator who transfers, stores, treats, or disposes of dangerous waste on-site shall perform his operations in accordance with the TSD facility requirements of this chapter."

\section{STTE REQUIREMENT SOURCE: WAC-173-303 Section 170 (5)}

"170 (5) The generator must comply with the special land disposal restrictions for certain dangerous wastes in WAC 173-303-140."

\section{SITE REQUIREMENT SOURCE: WAC-173-303 Section 170(4)(b)}

"Pursuant to the requirements of WAC 173-303-200, accumulate special waste in containers and tanks for up to one hundred eighty days, and accumulate special waste in piles for up to ninety days provided that he complies with WAC 173-303-660 (2), (3)(a), (b)(i), (ii)(A), (7), (8), and (9)(a)."

\section{SITE REQUIREMENT SOURCE: WAC-173-303 Section 200}

"Accumulating dangerous waste on-site.

200 (1) A generator, not to include transporters as referenced in WAC 173-303-240(3), may accumulate dangerous waste on-site without a permit for ninety days or less after the date of generation, provided that:

200 (1) (a) All such wasto is shippod off-site to a designated facility or placed in an on-site facility which is permitted by the department under WAC 173-303-800 through 173-303-845 in ninety days or less. The department may, on a case-by-case basis, grant a maximum thirty day extension to this ninety day period if dangerous wastes must remain on-sito due to unforeseen, temporary and uncontrollable circumstances. A generator who accumulates dangerous waste for more than ninety days is an operator of a storage facility rnd is subject to the facility requirements of this chapter and the permit requirements of this chapter as a storage facility unless he has been granted an extension to the ninety day period allowed pursuant to this subsection;

200 (1) (b) The waste is placed in containers and the generator complies with WAC 173-303-630 (2), (3), (4), (5), (6), (8), and (9), or the waste is placed in tanks and the generator complies with WAC 173-303-640 (2) through (10), except WAC 173-303-640 (8)(c) 


\section{REQUTREMENTS IDENTIFICATION DOCUMENT FIGH LEVEL WASTE STORAGE TANK FARMS Environmental Restoration and Waste Management Revision 0}

and the eccond sentence of WAC 173-303-640 (8)(a). (Note: A generator, unlese otherwise required to do so, does not have to prepare a closure plan, a cost estimate for closure, or provide financial reeponsibility for his tank system to satisfy the requirements of this section. In lieu of the "sufficieat freeboard" requiremeat of WAC 173-303-640 (5)(b)(iii) for uncoverod tanks, the generator must maintrin a minimum freeboard of two feet. Such a generator is oxempt from the requirements of WAC 173-303-620 and 173-303-610, oxcopt for WAC 173-303-610 (2) and (5). For container accumulation (including atellito areas as doacribed in subsection (2)(c) of this soction), the department may require that the sccumulation area inclu20 or mixtures, WAC 173-202-084, secondary containmeat in accordance with WAC 173-303-630(7), if the departmeat dotermines that there is a potential threat to public health or the environment due to the mature of the wastes being accumulated, or due to a history of apills or releases from accumulated containers. In addition, any now container accumulation areas (but not including now eatellite areas, unloes required by the department) constructed or installed after September 30, 1986, must comply with the provisions of WAC 173-303-630(7);

200 (1) (c) The dato upon which each period of accumulation begins is marked and clearly visible for inspection on each container;

200 (1) (d) Whilo being sccumulated on site, each container and tank is laboled or marked clearly with the words "dangerous waste" or "hazardous waste." Each container or tank must also be marked with a label or sign which identifies the major risk(s) associated with the wasto in the container or tank for employees, emergency response personnel and the public (Noto-If there is already a system in use that performs this function in accordance with local, state, or federal rogulations, then such system will bo adequate); and

200 (1) (e) The generator complies with the requirements for facility operators contained in WAC 173-303-330 through 173-303-360 (personnel training, proparedness and provention, contingency plan and emergency procedures, and emergencies), and WAC 173-303-320 (1), (2)(a), (b), (d), and (3) (general inspection).

200 (1) (i) He accumulates dangerous waste on-site for ten or more calendar days; or

200 (1) (ii) Ho is directed by the department to so comply, due to potential threats to public health or the environment. In such case, the department may require that he comply with all of or only parts of WAC 173-303-330 through $173-303-360$, as necessary to mitigate the potential threats to public health or the environment.

200 (2) For the purposes of this section, the ninety-day accumulation period begins on the date that:

200 (2) (a) The generator first generates a dangerous waste; or

200 (2) (b) The quantity (or aggregated quantity) of dangerous waste being accumulated by a small quantity generator first exceeds the quantity exclusion limit for such waste (or wastes); or

200 (2) (c) The quantity of dangerous waste being accumulated in containers in a satellite area exceeds fifty-five gallons of dangerous waste or one quart of acutely hazardous waste (see WAC 173-303-040). For the purposes of this section, a satellite area shall be a location at or near any point of generation where wastes initially accumulate, which is under the control of the operator of the process generating the waste. 


\section{REQUIREMENTS IDENTIFICATION DOCUMENT HIGH LEVEL WASTE STORAGE TANK FARMS Environmental Restoration and Waste Management Revision 0}

[Stututory Authority: Chapter 70.105 RCW. 86-12-057 (Order DE-85-10), SS 173-303-200, filed 6/3/86; 84-14-031 (Order DE 84-22), SS 173-303-200, filed 6/27/84. Statutory Authority: Chapter 70.105 RCW and RCW 70.95.260. 82-05-023 (Order DE 81-33), SS 173-303-200, filed 2/10/82.]"

\section{Waste Treatment}

This subelement apecifies the requirements of 40 CFR265.400 for bazardous waste treatment.

\section{SITE REQUTREMENT SOURCE: 40CFR265 Section 400}

-Applicability.

The regulations in this subpart apply to owners and operators of facilities which treat hazardous wastes by chemical, physical, or biological methods in other then tanks, surface impoundments, and land treatment facilities, except as 265.1 provides otherwise. Chemical, phyaical, and biological treatment of bazardous wasto in teaks, surface impoundments, and land treatment facilitios must be conductod in accordence with subparts J, K, and M, reopectively."

\section{STTE REQUTREMENT SOURCE: 40CFR265 Section 401}

"General operating requiremonts.

(a) Chemical, physical, or biological treatment of hazardous waste must comply with 265.17(b).

(b) Hezardous wastes or treatment reagents must not be placed in the treatment process or equipment if they could cause the treatment process or equipment to rupture, leak, corrode, or otherwise fail before the end of its intended life.

(c) Where hazardous wasto is continuously fed into a treatment process or equipment, the process or equipment must be equipped with a means to stop this inflow (e.g., a waste feed cut-off system or by-pass system to a standby containment devico).

[Comment: These systems are intended to be used in the event of a malfunction in the treatment process or equipment.]"

\section{SITE REQUIREMENT SOURCE: 40CFR265 Section 403}

\section{"Inspections.}

(a) The owner or operator of a treatment facility must inspect, where present:

(1) Dischargo control and safety equipment (e.8., waste feed cut-off systems, by-pass systems, drainage systems, and pressure relief systems) at least once each operating day, to ensure that it is in good working order;

(2) Data gathered from monitoring equipment (e.g., pressure and temperature gauges), at least once each operating day, to ensure that the treatment process or equipment is being operated according to its design; 


\section{REQUTREMENTS IDENTIFICATION DOCUMENT HIGH LEVLL WASTE STORAGE TANK FARMS Environmental Restoration and Waste Management \\ Revidion 0}

(3) The construction materials of the treatment process of equipmeat, at least weakly, to dotect corrovion or leaking of fixtures or eams; and (4) The conetruction materials of, and the aren immodiataly surrounding, diecherge confinemeat atructures (0.8., dikes), at least woakly, to dotect erovion or obvious signs of leakage (0.8., wot upots or dead vegetation).

[Commeat: As required by 265.1S(c), the owner or operator must romedy any deterioration or malfunction be finde.]"

\section{SITE REQUTREMENT SOURCE: 4OCFR265 Section 404}

"Closure.

At closure, all hasardous wasto and besardous wasto reajduce must be removed from treatment procenses or equipment, dischurge control equipmeat, and discharge confinement etructures.

[Commeat: At clonure, as throughout the operating period, unleas the owner or operator can demonstrate, in eccordance with 261.3 (c) or (d) of this chapter, that any solid wasto removed from his treatment process or equipment is not a hazardous waste, the owner or operator becomes a generator of hazardous wasto and must manage it in accordance with all applicable requiremeats of parts 262, 263, and 265 of this chapter.]"

\section{SITE REQUIREMENT SOURCE: 40CFR265 Section 405}

"Special requirements for ignitable or reactive wasto.

(a) Ignitable or reactive waste muat not bo placed in a treatment procese or equipment unleas:

(1) The wasto is treatod, rendered, or mixed before or immodiately after placement in the treatment process or equipment so that (i) the resulting waste, mixture, or dissolution of material no longer moets the dofinition of ignitable or reactive waste under 261.21 or 261.23 or this chapter, and (ii) 265.17 (b) is complied with; or

(2) The waste is treated in such a way that it is protected from any material or conditions which may cause the waste to ignite or react."

\section{SITE REQUIREMENT SOURCE: 40CFR265 Section 406}

"Special requirements for incompatible wastes.

(a) Incompatible wastes, or incompatible wastes and materials, (see appendix V for examples) must not be placed in the same treatment process or equipment, unless 265.17(b) is compliod with. (b) Hezardous wasto must not be placed in unwashed treatment equipment which previously held an incompatible waste or material, unless $265.17($ b) is complied with."

\section{Waste Manifest. Plans and Records}

This subelement specifies the requirements for waste manifesting, recordkeeping, and contingency planning. Operational controls should include collection of current waste volume inventories of tanks containing hazardous liquid waste materials. Waste inventory data must be captured and archived from all past and present systems to allow the establishment of tread analyses and long term inventory assessments. Controls should to be established to maintain 


\section{REQUIREMENTS IDENTIFICATION DOCUMENT HIGH LEVEL WASTE STORAGE TANK FARMS Environmental Restoration and Waste Management \\ Revision 0}

manifects and documeat wasto identification, chanacterization of the wasto, generator identification, carrier and recoiver ideatification and applicable permit information.

\section{FACILITY REQUIREMIENT SOURCE: WAC-173 Section 303-210 (3)}

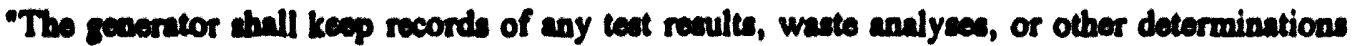
made in cocordance with WAC 173-303-170(1) for devignating dangerous waste for at least five years from the deto that the wasto wal lat trunsforred for on-aite or off-sito treatmeat, etorage or dispoen."

\section{FACLITY REQUTREMINT SOURCE: WAC-173 Section 303-380 (1)}

"WAC 173-303-380 Fecility recordkeoping.

Operating record. The owner or operator of a facility shall keep a written operating record at his facility. The following information shall be reconded, as it becomes available, and maintained in the operating record until closure of the facility:

(a) A deacription of and the quantity of each dangerous waste received or managed on-site, and the method(s) and date(s) of its treatment, stornge, or disposal at the facility as required by subection (2) of this soction, recordkeeping instructions;

(b) The location of ach dargerous waste within the facility and the quantity at each location. For diepoeal facilities, the location and quentity of each dangerous wasto must be recorded on a map or diagram of each cell or disposal area. For all facilities, this information must include crose-reforences to epecific manifest document numbers, if the wasto was accompanied by a manifest;

(c) Records and recults of waste analyses required by WAC 173-303-300, General waste analysis;

(d) Summary reports and dotuils of all incidents that require implementing the contingency plan, as specified in WAC 173-303-360 (2)(k):

(o) Records and results of inspections as required by WAC 173-303-320 (2)(d), General inspection (except such information need be kept only for five years);

(f) Monitoring, toeting, or analytical data where required by 40 CFR Part 265 Subparts $F$ through R for interim status facilitios, and by WAC 173-303-630 through 173-303-670 for final status facilities;

(g) All closure and post-closure cost estimates required for the facility;"

\section{SITE REQUIREMENT SOURCE: WAC-173-303 Section 060(5)}

"Any porson with a current EPA/state ID No. must submit an annual report as required by WAC 173-303-070(8), 173-303-220, and 173-303-390. Any person that has withdrawn or cancelled their ID No. and recoived confirmation from the department must submit an annual report for the calendar year in which their request was approved." 


\section{REQUIREMENTS IDENTIFICATION DOCUMENT HIGH LEVEL WASTE STORAGE TANK FARMS Environmental Restoration and Waste Management Revision 0}

\section{STTE REQUTREMENT SOURCE: WAC-173-303 Section 180}

"Manifeat. Bofore traneporting dangerous waste or offering dangerous waste for transport off the site of generation, the generator shall prepare a manifest and shall follow all applicable procedures doscribed in this section.

180 (1) This abbection deacribes the form and contents of dangerous waste manifests. 40 CFR Part 262 Appendix -Uniform Hazandous Waste Manifeat and Instructions (EPA Forms 8700-22 and 8700-22A and Their Instructions) is adopted by reference. The manifest shall be EPA Form 8700-22 and, if neceasary, BPA Form 8700-22A. The manifost must be prepared in accordance with the instructions for these forms, as described in the uniform manifest Appendix of 40 CFR Part 262, and in addition must contain the following information in the apecified ahaded items of the uniform manifeat:

180 (1) (a) Item D, and $O$ if the continuation sheet 8700-22A is used - The first transporter's tolephono number must bo provided in this space;

180 (1) (b) Item F, and $Q$ if the continuation sheel 8700-22A is used - If a second transporter is used, then the second trunsporter's tolephone number must be provided in this space;

180 (1) (c) Itom H - The designuted receiving facility's telephone number must be provided in this space; and

180 (1) (d) Item I, and R if the continuation sheet 8700-22A is used - The dangerous waste number (0.8., F001, D006, WTO2, P102) must be provided in this space for each correeponding waste entered and described under Item 11, and 28 if the continuation sheet 8700-22A is used. As discussed in subsection (5) of this section, dangerous waste numbers WLO1 or WLO2 may be used in this space for labpacks.

180 (2) The manifest shall consist of enough copies to provide the generator, transporter(s), and facility owner/operator with a copy, and a copy for return to the generator.

180 (3) Manifest procedures.

180 (3) (a) The generator shall:

180 (3) (i) Sign and date the manifest certification by hand;

180 (3) (ii) Obtain the bandwritten signature of the initial transporter and date of acceptance on the manifest; and

180 (3) (iii) Retain one copy in accordance with WAC 173-303-210, Generator recordkeeping.

180 (3) (b) The generator shall give the remaining manifest copies to the transporter.

180 (3) (c) If the transporter is unable to deliver the dangerous waste shipment to the designated facility or the alternate facility, the generator must either designate another facility or instruct the transporter to return the waste shipment.

180 (3) (d) For shipments of dangerous waste within the United States solely by water (bulk shipments only), the generator must send three copies of the manifest dated and signed in accordance with this section to the owner or operator of the designated facility or the last 


\section{REQUIREMENTS IDENTIFICATION DOCUMENT HIGH LEVEL WASTE STORAGE TANK FARMS Environmental Restoration and Waste Management \\ Revision 0}

water (bulk ahipment) traseporter to handle the wasto in the United States if exported by water. Copies of the manifest are not required for each transporter.

180 (3) (0) For rail shipments of dangerous wasto within the Unitod States which originate at the site of generation, the generator must send at least throe copies of the menifest dated and signed in accordance with this section to:

180 (3) (i) The next nonrail transporter, if any; or

180 (3) (ii) The designated facility if transported solely by rail; or

180 (3) (iii) The last rail transporter to handle the waste in the United States if exported by nil.

180 (4) Special requirements for shipments to the Washington EHW facility at Henford.

180 (4) (a) All generators planning to ship dangerous waste to the EHW facility at Hanford shall notify the facility in writing and by sending a copy of the prepared manifest prior to shipment.

180 (4) (b) The genorator shall not ship any dangerous waste without prior approval from the EHW facility. The state operator may exempt classes of waste from the requirements of WAC 173-303-180 (4)(a) and (b) where small quantities or multiple shipments of a proviously approved waste are involved, or there exists an emergency and potential threat to public health and safety.

180 (5) Special instructions for shipment of labpacks. For purposes of completing the uniform dangerous waste menifest, dangerous wasto numbers WLO1 (for labpacks containing wastes designated as EHW) or WLO2 (for labpacks containing wastes designated only as DW) may be used to complete Items $I$ and $R$ in liou of the dangerous waste numbers that would otherwise be assigned to the contents of the labpack.

\section{SITE REQUIREMENT SOURCE: WAC-173-303 Section 210}

"Generator recordkeeping.

210 (1) The generator shall keep a copy of each manifest signed by the initial transporter in accordance with WAC 173-303-180(3), manifest procedures, for three years, or until he receives a signed copy from the designated facility which received the waste. The signed facility copy shall be retained for at least five years from the date the waste was accepted by the initial transporter.

210 (2) The generator shall keep a copy of each annual report and exception report as required by WAC 173-303-220 for a period of at least five years from the due date of each report. The generator shall keep a copy of his most recent notification (Form 2) until he is no longer defined as a generator under this chapter.

210 (3) The generator shall keep records of any test results, waste analyses, or other determinations made in accordance with WAC 173-303-170(l) for designating dangerous wasto for at least five years from the date that the wasto was last transferred for on-site or off-site treatment, storage or disposal. 


\section{REQUIREMENTS IDENTIFICATION DOCUMENT HIGH LEVEL WASTE STORAGE TANK FARMS Environmental Restoration and Waste Management Revision 0}

210 (4) Any other records required for generators accumulating wastes on-site as described in WAC 173-303-170 (4)(b) or 173-303-200 must be retained for at least five years, including, but not limited to such items as inspection logs and operating records.

210 (5) The periods of retention for any records described in this section shall be automatically extended during the course of any unresolved enforcement action requiring those records or upon request by the director.

210 (6) All generator records, including plans required by this chapter, shall be made available and furnished upon request by the director.

\section{SITE REQUIREMENT SOURCE: WAC-173-303 Section 350(1)}

"Purpose. The purpose of this section and WAC 173-303-360 is to lessen the potential impact on the public health and the environment in the event of an emergency circumstance, including a fire, explosion, or unplanned sudden or nonsudden release of dangerous waste or dangerous waste constituents to air, soil, surface water, or ground water by a facility. A contingency plan must be developed to lessen the potential impacts of such emergency circumstances, and the plan shall be implemented immodiately in such emergency circumstances."

\section{SITE REQUIREMENT SOURCE: WAC-173-303 Section 350(2)}

"Contingency plan. Each owner or operator must bave a contingency plan at his facility for use in emergencies or sudden or nonsudden releases which threaten the public health and the environment. If the owner or operator has already prepared a spill prevention control and countermeasures (SPCC) plan in accordance with Part 112 of Title 40 CFR or Part 1510 of chapter V, or some other emergency or contingency plan, he need only amend that plan to incorporate dangerous waste management provisions that are sufficient to comply with the requirements of this section and WAC 173-303-360."

\section{SITE REQUIREMENT SOURCE: WAC-173-303 Section 350(3)}

"The contingency plan must contain the following:

350 (3) (a) A description of the actions which facility personnel must take to comply with this section and WAC 173-303-360;

350 (3) (b) A description of the actions which shall be taken in the event that a dangerous waste shipment, which is damaged or otherwise presents a hazard to the public bealth and the environment, arrives at the facility, and is not acceptable to the owner or operator, but cannot be transported, pursuant to the requirements of WAC 173-303-370(5), Manifest system, reasons for not accepting dangerous waste shipments;

350 (3) (c) A description of the arrangements agreed to by local police departments, fire departments, hospitals, contractors, and state and local emergency response teams to coordinate emergency services;

350 (3) (d) A current list of names, addresses, and phone numbers (office and home) of all persons qualified to act as the emergency coordinator required under WAC 173-303-360(l). Where more than one person is listed, one must be named as primary emergency coordinator, and others must be listed in the order in which they will assume responsibility as alternates. 


\section{REQUIREMENTS IDENTIFICATION DOCUMENT \\ HIGH LEVEL WASTE STORAGE TANK FARMS \\ Environmental Restoration and Waste Management \\ Revision 0}

For new facilities only, this list may be provided to the department at the time of facility certification (as required by WAC 173-303-810(14)(a)(i)), rather than as part of the permit application;

350 (3) (e) A list of all emergency equipment at the facility (such as fire extinguishing systems, spill control equipment, communications and alarm systems, and decontamination equipment), where this equipment is required. This list must be kept up to date. In addition, the plan must include the location and a physical description of each item on the list, and a brief outline of its capabilities; and

350 (3) (f) An evacuation plan for facility perscinel where there is a possibility that evacuation could be necessary. This plan must describe the signal(s) to be used to begin evacuation, evacuation routes, and alternate evacuation routes."

SITE REQUIREMENT SOURCE: WAC-173-303 Section 350(4)

"Copies of contingency plan.

A copy of the contingency plan and all revisions to the plan shall be:

350 (4) (a) Maintained at the facility; and

350 (4) (b) Submitted to all local police departments, fire departments, hospitals, and state and local emergency response teams that may be called upon to provide emergency services."

SITE REQUIREMENT SOURCE: WAC-173-303 Section 350(5)

"Amendments.

The owner or operator shall review and immediately amend the contingency plan, if necessary, whenever:

350 (5) (a) Applicable regulations or the facility permit are revised;

350 (5) (b) The plan fails in an emergency;

350 (5) (c) The facility changes (in its design, construction, operation, maintenance, or other circumstances) in a way that materially increases the potential for fires, explosions, or releases of dangerous waste or dangerous waste constituents, or in a way that changes the response necessary in an emergency;

350 (5) (d) The list of emergency coordinators changes; or

350 (5) (e) The list of emergency equipment changes. "

$\underline{14.2 .4 .11}$

Closure

This subelement specifies the requirements of WAC 173-303-610 for facility closure. 


\section{REQUTREMENTS IDENTIFICATION DOCUMENT HIGH LEVEL WASTE STORAGE TANK FARMS Environmental Restoration and Waste Management Revision 0}

SITE REQUIREMENT SOURCE: WAC-173-303 Section 610 (1)

"(1) Applicability.

610 (1) (a) Subsections (2) through (6) of this section, (which concern closure), apply to the owners and operators of all dangerous waste facilities.

610 (1) (b) Subsections (7) through (11) of this section, (which concern post-closure care), apply to the owners and operators of all regulated units (as defined in WAC 173-303-040) at which dangerous waste will remain after closure, to tank systems that are required under WAC 173-303-640(8) to meet the requirements of landfills, to surface impoundments, waste piles and miscellaneous units as specified in WAC 173-303-650(6), 173-303-660(9), and 173-303-680(4), respectively and, unless otherwise authorized by the department, to the owners and operators of all facilities which, at closure, cannot meet the removal or decontamination limits specified in subsection (2)(b) of this section.

610 (1) (c) For the purposes of the closure and post-closure requirements, any portion of a facility which closes is subject to the applicable closure and post-closure standards even if the rest of the facility does not close and continues to operate.

610 (2) Closure performance standard. The owner or operator must close the facility in a manner that:

$610(2)(a)$

610 (2) (i) Minimizes the need for further maintenance;

610 (2) (ii) Controls, minimizes or eliminates to the extent necessary to protect buman health and the environment, post-closure escape of dangerous waste, dangerous constituents, leachate, contaminated run-off, or dangerous waste decomposition products to the ground, surface water, ground water, or the atmosphere; and"

\section{SITE REQUIREMENT SOURCE: WAC-173-303 Section 610 (2)}

"610 (2) Closure performance standard. The owner or operator must close the facility in a manner that:

$610(2)(a)$

610 (2) (i) Minimizes the need for further maintenance;

610 (2) (ii) Controls, minimizes or eliminates to the extent necessary to protect human health and the environment, post-closure escape of dangerous waste, dangerous constituents, leachate, contaminated run-off, or dangerous waste decomposition products to the ground, surface water, ground water, or the atmosphere; and

610 (2) (iii) Returns the land to the appearance and use of surrounding land areas to the degree possible given the nature of the previous dangerous waste activity.

610 (2) (b) Where the closure requirements of this section, or of WAC 173-303-630(10), 173-303-640(8), 173-303-650(6), 173-303-655(8), 173-303-660(9), 173-303-670(8), or 173-303-680 (2) through (4) call for the removal or decontamination of dangerous wastes, 


\section{REQUIREMENTS IDENTIFICATION DOCUMENT \\ HIGH LEVEL WASTE STORAGE TANK FARMS \\ Environmental Restoration and Waste Management \\ Revision 0}

waste residues, or equipment, bases, liners, soils or other materials containing or contaminated with dangerous wastes or waste residue, then such removal or decontamination must assure that the levels of dangerous waste or dangerous waste constituents or residues do not exceed:

610 (2) (i) Background environmental levels, for any dangerous waste, managed at the facility, which either is listed under WAC 173-303-081 or 173-303-082 or is designated by the characteristics of WAC 173-303-090; and

610 (2) (ii) At least the desigmation limits of WAC 173-303-084, or 173-303-101 through 173-303-103 for any dangerous waste, managed at the facility, which is not listed under WAC 173-303-081 or 173-303-082 and is not designated by the characteristics of WAC 173-303-090. In addition to these limits, the department may specify in the closure plan for a facility any lower limits for removal or decontamination which the department deems appropriate."

\section{SITE REQUIREMENT SOURCE: WAC-173-303 Section 610 (3)}

"610 (3) Closure plan; amendment of plan.

610 (3) (a) The owner or operator of a dangerous waste management facility must have a written closure plan. In addition, certain surface impoundments and waste piles from which the owner or operator intends to remove or decontaminate the dangerous waste at partial or final closure are required by WAC 173-303-650(6) and 173-303-660(9) to have contingent closure plans. The plan must be submitted with the permit application, in accordance with WAC 173-303-806(4), and approved by the department as part of the permit issuance procedures under WAC 173-303-840. The approved closure plan will become a condition of any permit. The department's decision must assure that the approved closure plan is consistent with subsections (2), (3), (4), (5), and (6) of this section, and the applicable requirements of WAC 173-303-630(10), 173-303-640(8), 173-303-650(6), 173-303-655(8), 173-303-660(9), 173-303-665(6), 173-303-670(8), and 173-303-680(2). A copy of the approved plan and all revisions to the plan must be furnished to the department upon request, including request by mail until final closure is completed and certified in accordance with subsection (6) of this section. The plan must identify steps necessary to perform partial and/or final closure of the facility at any point during its active life. The closure plan must include at least:

610 (3) (i) A description of how each dangerous waste management unit at the facility will be closed in accordance with subsection (2) of this section;

610 (3) (ii) A description of how final closure of the facility will be conducted in accordance with subsection (2) of this section. The description must identify the maximum extent of the operation which will be unclosed during the active life of the facility;

610 (3) (iii) An estimate of the maximum inventory of dangerous wastes ever on-site over the active life of the facility. (Any change in this estimate is a minor modification under WAC 173-303-830(4));

610 (3) (iv) A detailed description of the methods to be used during partial closures and final closure, including, but not limited to, methods for removing, transporting, treating, storing, or disposing of all dangerous wastes, and identification of the type(s) of the off-site dangerous waste management units to be used, if applicable;

610 (3) (v) A detailed description of the steps reeded to remove or decontaminate all dangerous waste residues and contaminated containment system components, equipment, 


\section{REQUIREMENTS IDENTIFICATION DOCUMENT HIGH LEVEL WASTE STORAGE TANK FARMS Environmental Restoration and Waste Management}

\section{Revision 0}

structures, and soils during partial and final closure, including, but not limited to, procedures for cleaning equipment and removing contaminated soils, methods for sampling and testing surrounding soils, and criteria for determining the extent of decontamination required to satisfy the closure performance standard;

610 (3) (vi) A detailed description of other activities necessary during the closure period to ensure that all partial closures and final closure satisfy the closure performance standards, including, but not limited to, ground water monitoring, leachate ccllection, and nun-on and run-off control; and

610 (3) (vii) A schedule for closure of each dangerous waste management unit and for final closure of the facility. The schedule must include, at a minimum, the total time required to close each dangerous waste management unit and the time required for intervening closure activities which will allow tracking of the progress of partial and final closure, (For example, in the case of a landfill unit, estimates of the time required to treat or dispose of all dangerous waste inventory and of the time required to place a final cover must be included.)

Additionally, for facilities that use trust funds to establish financial assurance under WAC $173-303-620$ (4) or (6) and that are expected to close prior to the expiration of the permit, an estimate of the expected year of final closure.

610 (3) (b) The owner or operator must submit a written notification of or request for a permit modification to authorize a change in operating plans, facility design, or the approved closure plan in accordance with the applicable procedures in WAC 173-303-800 through 173-303-840. The written notification or request must include a copy of the amended closure plan for review or approval by the department.

610 (3) (i) The owner or operator may submit a written notification or request to the department for a permit modification to amend the closure plan at any time prior to the notification of partial or final closure of the facility.

610 (3) (ii) The owner or operator $n$ ust submit a written notification of or request for a permit modification to authorize a change in the approved closure plan whenever:

610 (3) (A) Changes in operating plans or facility design affect the closure plan; or

610 (3) (B) There is a change in the expected year of closure, if applicable; or

610 (3) (C) In conducting partial or final closure activities, unexpected events require a modification of the approved closure plan.

610 (3) (iii) The owner or operator must submit a written request for a permit modification including a copy of the amended closure plan for approval at least sixty days prior to the proposed change in facility design or operation, or no later than sixty days after an unexpected event has occurred which has affected the closure plan. If an unexpected event occurs during the partial or final closure period, the owner or operator must request a permit modification no later than thirty days after the unexpected event. An owner or operator of a surface impoundment or waste pile that intends to remove all dangerous waste at closure and is not otherwise required to prepare a contingent closure plan under WAC 173-303-650(6) or 173-303-660(9), must submit an amended closure plan to the department no later than sixty days from the date that the owner or operator or department determines that the dangerous waste management unit must be closed as a landfill, subject to the requirements of WAC 173-303-665, or no later than thirty days from that date if the determination is made during 


\section{REQUIREMENTS IDENTIFICATION DOCUMENT HIGH LEVEL WASTE STORAGE TANK FARMS Environmental Restoration and Waste Management Revision 0}

partial or final closure. The department will approve, disapprove, or modify this amended plan in accordance with the procedures in WAC 173-303-800 through 173-303-840. The approved closure plan will become a condition of any permit issued.

610 (3) (iv) The department may request modifications to the plan under the conditions described in (b)(ii) of this subsection. The owner or operator must submit the modified plan within sixty days of the department's request, or within thirty days if the change in facility conditions occurs during partial or final closure. Any modifications requested by the department will be approved in accordance with the procedures in WAC 173-303-800 through 173-303-840.

610 (3) (c) Notification of partial closure anc final closure.

610 (3) (i) The owner or operator must notify the department in writing at least sixty days prior to the date on which he expects to begin closure of a surface impoundment, waste pile, land treatment, or landfill unit, or final closure of a facility with such a unit. The owner or operator must notify the department in writing at least forty-five days prior to the date on which he expects to begin final closure of a facility with only treatment or storage tanks, container storage, or incinerator units to be closed.

610 (3) (ii) (A) The date when he "expects to begin closure" must be either no later than thirty days after the date on which any dangerous waste management unit receives the known final volume of dangerous wastes or, if there is a reasonable possibility that the dangerous waste management unit will receive additional dangerous wastes, no later than one year after the date on which the unit received the most recent volume of dangerous waste. If the owner or operator of a dangerous waste management unit can demonstrate to the department that the dangerous waste management unit or facility has the capacity to receive additional dangerous wastes and he has taken, and will continue to take, all steps to prevent threats to human health and the environment, including compliance with all applicable permit requirements, the department may approve an extension to this one-year limit.

610 (3) (B) For units meeting the requirements of subsection (4)(d) of this section, no later than thirty days after the date on which the dangerous waste management unit receives the known final volume of nondangerous wastes, or if there is a reasonable possibility that the dangerous waste management unit will receive additional nondangerous wastes, no later than one year after the date on which the unit received the most recent volume of nondangerous wastes. If the owner or operator can demonstrate to the department that the dangerous waste management unit has the capacity to receive additional nondangerous wastes and he has taken, and will continue to take, all steps to prevent threats to human health and the environment, including compliance with all applicable permit requirements, the department may approve an extension to this one-year limit.

610 (3) (iii) If the facility's permit is terminated, or if the facility is otherwise ordered, by judicial decree or final order to cease receiving dangerous wastes or to close, then the requirements of (c) of this subsection do not apply. However, the owner or operator must close the facility in accordance with the deadlines established in subsection (4) of this section.

610 (3) (iv) Removal of wastes and decontamination or dismantling of equipment. Nothing in this subsection shall preclude the owner or operator from removing dangerous wastes and decontaminating or dismantling equipmeat in accordance with the approved partial or final closure plan at any time before or after notification of partial or final closure." 


\section{REQUTREMENTS IDENTIFICATION DOCUMENT HIGH LEVEL WASTE STORAGE TANK FARMS Environmental Restoration and Waste Management Revision 0}

\section{SITE REQUIREMENT SOURCE: WAC-173-303 Section 610 (4)}

"610 (4) Closure; time allowed for closure.

610 (4) (a) Within ninety days after receiving the final volume of dangerous wastes, or the final volume of nondangerous wastes if the owner or operator complies with all applicable requirements in (d) and (e) of this subsection, at a dangerous waste management unit or facility, the owner or operator must treat, remove from the unit or facility, or dispose of on site, all dangerous wastes in accordance with the approved closure plan. The department may approve a longer period if the owner or operator complies with all applicable requirements for requesting a modification to the permit and demonstrates that he has taken and will continue to take all steps to prevent threats to human health and the environment, including compliance with all applicable permit requirements, and either:

610 (4) (i) The activities required to comply with this paragraph will, of necessity, take longer than ninety days to complete; or

610 (4) (ii)

610 (4) (A) The dangerous waste management unit or facility has the capacity to receive additional dangerous wastes, or has the capacity to receive nondangerous wastes if the owner or operator complies with (d) and (e) of this subsection;

610 (4) (B) There is a reasonable likelihood that he or another person will recommence operation of the dangerous waste management unit or the facility within one year; and

610 (4) (C) Closure of the dangerous waste management unit or facility would be incompatible with continued operation of the site.

610 (4) (b) The owner or operator must complete partial and final closure activities in accordance with the approved closure plan and within one hundred eighty days after receiving the final volume of dangerous wastes, or the final volume of nondangerous wastes if the owner or operator complies with all applicable requirements in (d) and (e) of this subsection, at the dangerous waste management unit or facility. The department may approve an extension to the closure period if the owner or operator complies with all applicable requirements for requesting a modification to the permit and demonstrates that he has taken and will continue to take all steps to prevent threats to human health and the environment from the unclosed but not operating dangerous waste management unit or facility, including compliance with all applicable permit requirements, and either:

610 (4) (i) The partial or final closure activities will, of necessity, take longer than one hundred eighty days to complete; or

610 (4) (ii)

610 (4) (A) The dangerous waste management unit or facility has the capacity to receive additional dangerous wastes, or has the capacity to receive nondangerous wastes if the owner or operator complies with (d) and (e) of this subsection;

610 (4) (B) There is reasonable likelihood that he or another person will recommence operation of the dangerous waste management unit or the facility within one year; and 


\section{REQUIREMENTS IDENTIFICATION DOCUMENT HIGH LEVEL WASTE STORAGE TANK FARMS Environmental Restoration and Waste Management Revision 0}

610 (4) (C) Closure of the dangerous waste management unit or facility would be incompatible with continued operation of the site.

610 (4) (c) The demonstrations referred to in (a) and (b) of this subsection must be made as follows: The demonstrations in (a) of this subsection must be made at least thirty days prior to the expiration of the specified ninety-day period; and the demonstration in (b) of this subsection must be made at least thirty days prior to the expiration of the specified one hundred eighty-day period unless the owner or operator is otherwise subject to the deadlines in (d) of this subsection.

610 (4) (d) The department may allow an owner or operator to receive only nondangerous wastes in a landfill, land treatment, or surface impoundment unit after the final receipt of dangerous wastes at that unit if:

610 (4) (i) The owner or operator requests a permit modification in compliance with all applicable requirements in WAC 173-303-830 and 40 CFR Part 124 and in the permit modification request demonstrates that:

610 (4) (A) The unit has the existing design capacity as indicated on the part A application to receive nondangerous wastes; and

610 (4) (B) There is a reasonable likelihood that the owner or operator or another person will receive nondangerous wastes in the unit within one year after the final receipt of dangerous wastes; and

610 (4) (C) The nondangerous wastes will not be incompatible with any remaining wastes in the unit, or with the facility design and operating requirements of the unit or facility under this part; and

610 (4) (D) Closure of the dangerous waste management unit would be incompatible with continued operation of the unit or facility; and

610 (4) (E) The owner or operator is operating and will continue to operate in compliance with all applicable permit requirements; and

610 (4) (ii) The request to modify the permit includes an amended wastes analysis plan, ground water monitoring and response program, human exposure assessment required under RCRA section 3019, and closure and postclosure plan, and updated cost estimates and demonstrations of financial assurance for closure and postclosure care as necessary and appropriate, to reflect any changes due to the presence of dangerous constituents in the nondangerous wastes, and changes in closure activities, including the expected year of closure if applicable under subsection (3)(a)(vii) of this section, as a result of the receipt of nondangerous wastes following the final receipt of dangerous wastes; and

610 (4) (iii) The request to modify the permit includes revisions, as necessary and appropriate, to affected conditions of the permit to account for the receipt of nondangerous wastes following receipt of the final volume of dangerous wastes; and

610 (4) (iv) The request to modify the permit and the demonstration referred to in (d)(i) and (ii) of this subsection are submitted to the department no later than one hundred twenty days prior to the date on which the owner or operator of the facility receives the known final volume of dangerous wastes at the unit, or no later than ninety days after the effective date of 


\section{REQUIREMENTS IDENTIFICATION DOCUMENT HIGH LEVEL WASTE STORAGE TANK FARMS Environmental Restoration and Waste Management Rerision 0}

this rule in the state in which the unit is located, whichever is later.

610 (4) (0) In addition to the requirements in (d) of this subsection, an owner or operator of a dangerous wastes surface impoundment that is not in compliance with the liner and leachate collection system requirements in 42 U.S.C. $3004(0)(2)$ or (3) or $3005(j)(2),(3),(4)$ or (13) must:

610 (4) (i) Submit with the request to modify the permit:

610 (4) (A) A contingent corrective measures plan, unless a corrective action plan has already been submitted under WAC 173-303-645(10); and

610 (4) (B) A plan for removing dangerous wastes in compliance with (o)(ii) of this subsection; and

610 (4) (ii) Remove all dangerous wastes from the unit by removing all dangerous liquids, and removing all dangerous sludges to the extent practicable without impairing the integrity of the liner(s), if any.

610 (4) (iii) Removal of dangerous wastes must be completed no later than ninety days after the final receipt of dangerous wastes. The department may approve an extension to this deadline if the owner or operator demonstrates that the removal of dangerous wastes will, of necessity, take longer than the allotted period to complete and that an extension will not post a threat to buman bealth and the environment.

610 (4) (iv) If a release that is a statistically significant increase (or decrease in the case of $\mathrm{pH}$ ) over background values for detection monitoring parameters of constituents specified in the permit or that exxceeds the facility's ground water protection standard at the point of compliance, if applicable, is detected in accordance with the requirements in subpart $F$ of this part; the owner or operator of the unit:

610 (4) (A) Must implement corrective measures in accordance with the approved contingent corrective measures plan required by (e)(i) of this subsection no later than one year after detection of the release, or approval of the contingent corrective measures plan, whichever is later.

610 (4) (B) May continue to receive wastes at the unit following detection of the release only if the approved corrective measures plan includes a demonstration that continued receipt of wastes will not impede corrective action; and

610 (4) (C) May be required by the department to implement corrective measures in less than one year or to cease the receipt of wastes until corrective measures have been implemented if necessary to protect human health and the environment.

610 (4) (v) During the period of corrective action, the owner or operator shall provide semiannual reports to the department that describe the progress of the corrective action program, compile all ground water monitoring data, and evaluate the effect of the continued receipt of nondangerous wastes on the effectiveness of the corrective action.

610 (4) (vi) The department may require the owner or operator to commence closure of the unit if the owner or operator fails to implement corrective action measures in accordance with the approved contingent corrective measures plan within one year as required in (e)(iv) of this 


\section{REQUTREMENTS IDENTIFICATION DOCUMENT HIGH LEVEL WASTE STORAGE TANK FARMS Environmental Restoration and Waste Management Revision 0}

subection, or fails to make substantial progrees in implementing corrective action and achieving the facility's ground water protection standard or background lovels if the facility has not yet established a ground water protection standard.

610 (4) (vii) If the owner or operator fails to implement corrective measures as required in (0)(iv) of this subsection or if the department determines that substantial progress bas not been mede pursuent to (o)(vi) of this subsection the department shall:

610 (4) (A) Notify the owner or operator in writing that the owner or operator must begin closure in accordance with the deadline in (a) and (b) of this subsection and provide a detailed statement of reasons for this determination; and

610 (4) (B) Provide the owner or operator and the public, through a newspaper notice, the opportunity to submit written comments on the decision no later than twenty days after the date of the notice.

610 (4) (C) If the department receives no written comments, the decision will become final five days after the close of the comment period. The department will notify the owner or operator that the decision is final, and that a revised closure plan, if necessary, must be submitted within fifteen days of the final notice and that closure must begin in accordance with the deadlines in (a) and (b) of this subsection.

610 (4) (D) If the department receives written comments on the decision, it shall make a final decision within thirty days after the end of the comment period, and provide the owner or operator in writing and the public through a newspaper notice, a detailed statement of reasons for the final decision. If the department determines that substantial progress has not boen made, closure must be initiated in accordance with the deadlines in (a) and (b) of this subsection.

610 (4) (E) The final determinations made by the department under (e)(vii)(C) and (D) of this subsection are not subject to administrative appeal."

\section{SITE REQUIREMENT SOURCE: WAC-173-303 Section 610 (5)}

"610 (5) Disposal or decontamination of equipment, structures and soils. During the partial and final closure periods, all contaminated equipment, structures and soils must be properly disposed of or decontaminated unless otherwise specified in WAC 173-303-640(8), $173-303-650(6), 173-303-655(8), 173-303-660(9), 173-303-665(6)$, or under the authority of WAC 173-303-680 (2) and (4). By removing any dangerous wastes or dangerous constituents during partial and final closure, the owner or operator may become a generator of dangerous waste and must bandle that waste in accordance with all applicable requirements of WAC 173-303-170 through 173-303-230."

\section{SITE REQUIREMENT SOURCE: WAC-173-303 Section 610(6)}

"Certification of closure. Within sixty days of completion of closure of each dangerous waste management unit (including tank systems and container storage areas), and within sixty days of the comr letion of final closure, the owner or operator must submit to the department by registerel mail, a certification that the dangerous waste management unit or facility, as applicable, has been closed in accordance with the specifications in the approved closure plan. The certification must be signed by the owner or operator and by an independent registered professional engineer. Documentation supporting the independent registered professional 


\section{REQUIREMIENTS IDENTIFICATION DOCUMENT \\ HIGH LEVEL WASTE STORAGE TANK FARMS \\ Environmental Restoration and Waste Management \\ Revision 0}

engineer's certification must be furmisbed to the department upon request until it roleases the owner or operator from the finencial esenrance requirements for closure under WAC 173-303-620(4)."

\section{STIE REQUTREMENT SOURCE: WAC-173-303 Section 610(7)}

"Post-closure care and une of property.

610 (7) (a) Post-closure care for each dangerous waste management unit subject to post-closure requirements must begin after completion of closure of the unit and continue for thisty years after that date and must consiat of at least the following:

610 (7) (i) Ground water monitoring and reporting as applicable; and

610 (7) (ii) Maintenance and monitoring of waste containment systems as applicable.

610 (7) (b) Any time preceding partial closure of a dangerous waste management unit subject to post-closure care requirements or final closure, or any time during the post-closure period for a particular unit, the department may, in accordance with the permit modification procedures in WAC 173-303-800 through 173-303-840:

610 (7) (i) Shorten the post-closure care period applicable to the dangerous waste management unit, or facility, if all disposal units have been closed, if it finds that the reduced period is sufficient to protect buman bealth and the eavironment ( 0.8 ., leachate or ground water monitoring results, characteristics of the dangerous waste, application of advanced tochnology, or alternative disposal, treatment, or reuse techniques indicate that the dangerous waste management unit or facility is secure); or

610 (7) (ii) Extend the post-closure care period applicable to the dangerous waste management unit or facility if it finds that the extended period is necessary to protect buman health and the environment (e.8., leachate or ground water monitoring results indicate a potential for migration of dangerous waste at levels which may be harmful to human health and the environment).

610 (7) (c) The department may require, at partial or final closure, continuation of any of the security requirements of WAC 173-303-310 during part or all of the post-closure period when:

610 (7 (i) Dangerous wastes may remain exposed after completion of partial or final closure; or

610 (7) (ii) Access by the public or domestic livestock may pose a hazard to human bealth.

610 (7) (d) Post-closure use of property on or in which dangerous wastes remain after partial or final closure must never be allowed to distusb the integrity of the final cover, liner(s), or any other components of any containment system, or the function of the facility's monitoring systems, unless the department finds that the disturbance:

610 (7) (i) Is necessary to the proposed use of the property, and will not increase the potential hazard to human health or the environment; or

610 (7) (ii) Is necessary to reduce a threat to human health or the environment. 


\section{REQUIREMENTS IDENTIFICATION DOCUMENT HIGH LEVEL WASTE STORAGE TANK FARMS Environmental Restoration and Waste Management Reviaion 0}

610 (7) (e) All post-closure care activitios must be in accordance with the provisions of the approved poet-closure plen as specified in subsection (8) of this section."

\section{STTE REQUIREMENT SOURCE: WAC-173-303 Section 610(8)}

"Post-closure plen; amendmeat of plen.

610 (8) (a) The owner or operator of a dangerous waste diaposal unit muat bave a written poet-closure plan. In addition, certain surface impoundments and certain piles from which the owner or operator inteods to rexoove or decontaminate the dangerous wastes at partial or final closure are required by WAC 173-303-650 and 173-303-660, respectively, to have written contingeat post-closure plans. Owners or operators of surface impoundmeats and waste piles not otherwise required to prepare contingeat post-closure plans under WAC 173-303-650 or 173-303-660 must submit a post-closure plan to the department within ninety days from the date that the owner or operator or department determines that the dangerous waste management unit must be closed as a landfill, subject to the post-closure requirements. The plan must be submitted with the permit application, in accordance with WAC 173-303-806, and approved by the department as part of the permit issuance procedures under WAC 173-303-840. The approved post-closure plan will become a condition of any pernit issued.

610 (8) (b) For cach dangerous waste management unit subject to the requirements of this subsection, the post-closure plan must identify the activities which will be carried on after closure and the frequency of these activities, and include at least:

610 (8) (i) A description of the planned ground water monitoring activities and frequencies at which they will be performed;

610 (8) (ii) A description of the planned maintenance activities, and frequencies at which they will be performed, to ensure:

610 (8) (A) The integrity of the cap and final cover or other containment structures where applicable; and

610 (8) (B) The function of the facility monitoring equipment;

610 (8) (iii) And the name, address, and phone number of the person or office to contact about the dangerous waste disposal unit or facility during the post-closure care period.

610 (8) (c) Until final closure of the facility, a copy of the approved post-closure plan must be furnished to the department upon request, including request by mail. After final closure has been certified, the person or office specified in (b)(iii) of this subsection must keep the approved post-closure plan during the reacainder of the pust-closure period.

610 (8) (d) Amendment of plan. The owner or operator must submit a written notification of or request for a permit modification to authorizo a change in the approved post-closure plan in accordance with the applicable requirements of WAC 173-303-800 through 173-303-840. The written notification or request must include a copy of the amended post-closure plan for review or approval by the department.

610 (8) (i) The owner or operator may submit a written notification or request to the department for a permit modification to amend the post-closure plan at any time during the active life of the facility or during the post- closure care period. 


\section{REQUIREMENTS IDENTIFICATION DOCUMENT \\ BIGH LEVEL WASTE STORAGE TANK FARMS \\ Environmental Restoration and Waste Management}

Revirion 0

610 (8) (ii) The owner or operator must submit a written notification of or requeat for a permit modification to authorize a chenge in the approved post-closure plan whenever:

610 (8) (A) Changes in operating plans or facility design affect the approved post-closure plan; or

610 (8) (B) There is a chenge in the expected year of final closure, if applicable; or

610 (8) (C) Eveats which occur during the active life of the facility, including partial and final closures, affect the spproved poet-clocure plan.

610 (8) (iii) The owner or operator must submit a written request for a permit modification at least sixty days prior to the proposed change in facility design or operation, or no later than sixty days after an unexpected ovent bes occurred which has affected the post-closure plan. An owner or operator of a surface impoundment or waste pile that intends to remove all dangerous waste at closure and is not otherwise required to submit a contingent post-closure plan under WAC 173-303-650 or 173-303-660 must submit a post-closure plan to the department no later then ninety days after the date that the owner or operator or department determines that the dangerous waste management unit must be closed as a landfill, subject to the requirements of WAC 173-303-665. The department will approve, disapprove, or modify this plan in accordance with the procedures in WAC 173-303-800 through 173-303-840. The approved post-closure plan will become a permit condition.

610 (8) (iv) The department may request modifications to the plan under the conditions described in (d)(ii) of this subsection. The owner or operator must submit the modified plan no later than sixty days after the department's request, or no later than ninety days if the unit is a surface impoundment or waste pile not previously required to prepare a contingent post-closure plan. Any modifications requested by the department will be approved, disapproved, or modified in accordance with the procedures in WAC 173-303-800 through 173-303-840."

\section{Mixed Waste}

Radioactive mixed waste is radioactive waste (LLW, HLW, or TRU waste) that also contains dangerous waste as defined in WAC 173-303-040. Packages of radioactive mixed waste are generated for storage at Hanford site TSD facilities. The requirements specified in this document for classification, characterization, handling, and waste form criteria applicable to high-level waste, TRU waste, low-level waste, and hazardous waste are directly applicable to radioactive mixed waste. Radioactive mixed waste shall not be capable of generating any toxic gases, vapors, fumes, or liquids and shall meet the waste form criteria specified in DOE 5820.2A.

The requirements identified in the previous subelements for high-level waste, TRU waste, low-lovel waste, and hazardous waste are also applicable to radioactive mixed waste. These requirements will not be repeated bere.

\section{FACILITY REQUIREMENT SOURCE: DOE5400.3 Section 6.a[001]}

"The radioactive component of radioactive mixed waste is subject to the requirements of DOE 5820.2A." 


\section{REQUIREMENTS IDENTIFICATION DOCUMENT BIGH LEVEL WASTE STORAGE TANK FARMS \\ Environmental Restoration and Waste Management Revision 0}

\section{FACILITY REQYJREMENT SOURCE: DOE5400.3 Section 6.b}

"It is the policy of DOE to protect the environment and the safety and bealth of the public, DOE and DOE contractor employees by managing operations to the greatest extent practicable in a maneer that provides for the safo handling, transportation, treatment, storage, or dispoeal of hazardous and radioactive mixed wastes generated by those operations."

\section{FACILITY REQUIREMTENT SOURCE: DOE5400.3 Section 6.c}

"Implemeot a hazardous and radionctive mixed wasto program complying with applicable laws and regulations."

\section{FACIIITY REQUIREMENT SOURCE: DOES400.3 Section 6.d}

"Implement waste minimization meesures as specified in RCRA for bazardous and radioactive mixed wastes."

\section{CORRECTIVE ACTIONS}

Not applicable, Tank Farms is not an environmental restoration project.

\section{WASTE MINIMIZATION}

The Waste Minimization element provides the controls that should be established for a comprebensive waste minimization program with the objective to significantly reduce the costs for facility environmental compliance and cleanup through major reductions in the amount of waste requiring treatment, storage, and disposal. A comprebensive source reduction program should include facility goals which are based upon past results and expected future expectations of waste reduction to minimize volume inventories of hazardous substances contain within the facility. This program should consist of process modification objectives and ideas for the use of process optimization material substitution. A programmatic approach should be initiated that requires a reconfiguration and upgrade of tank and evaporator designs to reduce the potential for cross-contamination of different waste streams. Waste minimization controls should be employed that encourage at the programmatic level the development of innovative waste treatment technologies and research to reduce the tank volume inventories being transferred and stored.

\section{FACIITY REQUTREMENT SOURCE: DOE/EH0135 AX.2.14}

"Non-radioactive liquid discharges into radioactive waste systems are minimized."

\section{FACILITY REQUIREMENT SOURCE: DOE/EHO135 AX.2.3}

"Goals, based upon past results, and expected future operations, are established to reduce the total bazardous substances discharged to the environment."

\section{FACILITY REQUIREMENT SOURCE: DOE/EH0135 AX.2.6}

"Radioactive liquid waste is recovered and reused to the maximum exteat practicable. Waste streams are segregated during collection accorting to the treatment required for each waste stream." 


\section{REQUIREMENTS IDENTIFICATION DOCUMENT \\ HIGH LEVEL WASTE STORAGE TANK FARMS \\ Environmental Restoration and Waste Management \\ Revision 0}

\section{FACIITY REQUIREMENT SOURCE: DOE5400.3 Section 6.d}

"Implement waste minimization measures as specified in RCRA for hazardous and radioactive mixed wastes."

FACIIITY REQUIREMENT SOURCE: DOE5820.2A Chapter I, Section 3.b(7)(b)

"Programs should be developed and implemented to treat high-level waste in storage to prepare it for eventual conversion to suitable disposal forms, as such forns are developed. This may include separation of high-level waste in other waste categories, such as transuranic waste or low-level waste."

FACIITY REQUIREMENT SOURCE: DOE5820.2A Chapter III, Section 3.c(1)

"Waste Generation

(1) Technical and administrative controls shall be directed to reducing the gross volume of waste generated and/or the amount of radioactivity requiring disposal. Waste reduction efforts shall include consideration of process modification, process optimization, materials substitution and decontamination."

FACIITY REQUIREMENT SOURCE: DOE5820.2A Chapter III, Section 3.c(2)

"Waste Generation Reduction. All DOE-low-level waste generators shall establish auditable programs (goals, incentives, procedures, and reports) to assure that the amount of low-level waste generated and/or shipped for disposal is minimized."

FACIIITY REQUIREMENT SOURCE: DOE5820.2A Chapter III, Section 3.c(3)

"Waste Segregation. Each DOE-low-level waste generator shall separate uncontaminated waste from low-level waste to facilitate cost effective treatment and disposal."

FACIITY REQUIREMENT SOURCE: DOE5820.2A Chapter III, Section 3.c(4)

"Waste Minimization. Each DOE-low-level waste generator preparing a design for a new process or process change shall incorporate principles into the design that will minimize the generation of low-level waste."

14.4.1 Source Reduction

This subelement defines the source reduction requirements for the Tank Farm facility in accordance with DOE Order 5820.2A.

\section{FACILTY REQUIREMENT SOURCE: DOE/EH0135 AX.3.6}

"Controls limit the materials that may be taken into areas where they may become radioactively or chemically contaminated. 


\section{REQUIREMENTS IDENTIFICATION DOCUMENT \\ HIGH LEVEL WASTE STORAGE TANK FARMS \\ Environmental Restoration and Waste Management}

Revision 0

FACILITY REQUIREMENT SOURCE: DOE5820.2A Chapter I, Section 3.b(7)(a)

"Waste Treatment and Minimization

(a) For the purpose of economy and enhancing the safety of bigh-level waste storage, processing programs shall be developed and implemented at the generating site to reduce the quantity of waste being sent to storage, and techniques (e.g., evaporation) shall be implemented to reduce further the waste volume in storage."

The Décontamination and Decommissioning (D\&D) element should specify the programmatic controls, technology and practices necessary to accomplish timely and effective D\&D activities for shutdown and surplus contaminated facilities. Controls should also exist to ensure that contaminated facilities are maintained in a safe and environmentally sound condition prior to and after implementation of the associated D\&D activities including performance of surveillance and maintenance activities.

This element is currently not applicable during the operating phase of the Tank Farms Facility.

14.6

14.7

$\underline{14.7 .1}$

$\underline{14.7 .3}$

\section{RADIOLOGICAL PERFORMANCE ASSESSMENT}

This element specifies the technical approach used to assess the long term radiological performance of permanent waste disposal facilities such as the Grout Disposal Facility. Therefore, this element is not applicable to Tank Farms.

\section{KEY PROGRAM INTERFACES}

The programs with which the elements and subelements of this RID have the unique interfaces are the following, to the extent that they are directly related to the Tank Farms WM Program. Specific requirement interfaces are noted at the element/subelement level in previous sections of the RID.

\section{Engineering}

The Engineering (ED) Functional Area addresses and supports the Tank Farms WM Program in the technical evaluation of new equipment or processes proposed for waste treatment, minimization, transportation, and disposal efforts.

\section{Emergency Preparedness and Management}

The Emergency Preparedness and Management Functional Area addresses the centralized management within WM regarding emergency planning, preparedness, and response activities. These functions are segregated into three major areas: the Transportation Emergency Preparedness Program, the Tank Farm's Facility Emergency Preparedness Program, and the Tank Farm's Occurrence Notification and Reporting Program.

\section{Research and Development and Experimental Activities (R\&D/EA)}

The Research and Development and Experimental Activities (R\&D/EA) Functional Area should be integrated into the Tank Farm's WM Program through an administrative system that 


\section{REQUIREMENTS IDENTIFICATION DOCUMENT HIGH LEVEL WASTE STORAGE TANK FARMS Environmental Restoration and Waste Management \\ Revision 0}

involves the WM Program in the designing, upgrading of new treatment technologies or upgrade technologies of the existing Evaporator-242-A/Crystallizer.

The Environmental Protection Functional Area develops and implements programs that direct the Tank Farm's WM Program and provides oversight, confirmation, and independent verification of on-going WM program. Specific environmental programmatic interfaces for the Tank Farms WM Program should include the following:

a. A process the ensures that programs are in place that requires monitoring, surveillance, and inspection that are designed to prevent, detect, and mitigate leaks, spills, uncontrolled effluent discharges.

b. A process that ensures the appropriate ideatification of necessary environmental permits, permit application processes, permit contents, permit modification, permit tracking systems, and closure.

c. A process in which facilities must observe to comply with environmental protection laws and regulations.

c. A process which addresses the development of an environmental database that defines a reference point against which all future activities may be measured.

\subsubsection{Management Systems}

The Management Systems Functional Area provides the basic project management principles of DOE Order 4700.1, "Project Management Systems" and assists the Tank Farm's WM Program in applying these principles. Programmatic controls should be in place to ensure that activity-based management and project oriented management structures are addressed separately. The specific programmatic controls are included in the following subelements:

a. Technical Baseline documents the technical requirements needed to achieve the stated mission within Tank Farms.

b. Schedule Baseline Plan which identifies activity durations and milestones signifying status and completion of the Tank Farms mission.

c. Cost Baseline which delineates the total cost of the Tank Farms program in order to complete the technical baseline according to schedule.

\section{Occupation Safety and Health}

The OS\&H Functional Area addresses broad DOE safety and health goals and objectives and incorporates them into site-specific Westinghouse Hanford procedures and requirements. The Tank Farms WM Program must rely on the OS\&H functional area for establishing the health and safety controls required to perform WM functions. Specifically, the OS\&H functional area provides implementation procedures to control hazardous or toxic materials; physical hazards; hazards identification, surveillance, and communication; asbestos removal operation; hazardous materials bandling and emergency response; posting of danger signs and tags or safety instructional materials; storage of pressurized gases; lockout and tagout activities; and 


\section{REQUIREMENTS IDENTIFICATION DOCUMENT HIGH LEVEL WASTE STORAGE TANK FARMS Environmental Restoration and Waste Management \\ Revision 0}

explosive or combustible materials bandling, processing, storage, transportation, and shipping. The Tank Farm WM Program should integrate the OS\&H Functional Area into its Program which ideatifies the basic policy, responsibilities, authorities, program requirements and implementation criteria.

14.7 .7

\section{Packaging and Transportation}

The Packaging and Transportation Functional Area addresses and ensures all hazardous materials (particularly radioactive), substances, and waste, can be efficiently, economically, safely, legally packaged and transported. The Packaging and Transportation functional area assists the Tank Farm WM Program and maintains the responsibility with any waste packaging and transport of materials from the areas within the site boundary (i.e. Waste Unloading Facility 204-AR).

Quality Assurance

The Quality Assurance Functional Area mandated by DOE Order 5700.6(c) addresses the general requirements for the Tank Farms WM Program to adhere to the Facility and Hanford Site Quality Assurance Requirements Document. The Quality Assurance Functional Area and its requirements apply to all items, activities, and processes managed by the Tank Farms WM Program. The Quality Assurance Functional Area is integrated into the WM Program with three fundamental categories: management, performance and assessment. The integration of these categories should be included in the WM Program procedures for Tank Farms.

Radiological Protection

The Radiological Protection Functional Area addresses the radiological safety of Tank Farm employees, Hanford personnel, public, and the environment during all WM activities. This functional area is integrated into the OS\&H Functional Area.

\section{Training and Qualification}

The Training and Qualification Functional Area is integrated into the Tank Farms WM Program by defining the appropriate personnel selection, training, qualifications, and resources necessary to safely and efficiently perform WM activities.

\section{REFERENCES}

The following reference documents were used to prepare the Waste Management functional area document.

1) Washington Adminigtrative Code (WAC) 173-303, "Dangerous Waste Regulations," dated 2/5/93, (note: The latest issue is dated 12/8/93).

2) 40 CFR 268, "EPA Regulations on Land Disposal Restrictions," dated 8/31/93.

3) 40 CFR 61, "National Emissions Standards for Hazardous Air Pollutants, " dated 6/25/93.

4) 40 CFR 761, "Polychlorinated Biphenals (PCBs) Manufacturing, Processing, Distribution in Commerce, and use Prohibitions, dated 12/9/93. 


\section{REQUIREMENTS IDENTIFICATION DOCUMENT \\ HIGH LEVEL WASTE STORAGE TANK FARMS \\ Environmental Restoration and Waste Management \\ Revision 0}

5) DOE Order 5820.2A, "Radioactive Waste Management," dated 9/26/88.

6) DOE Order 5400.5, "Radiation Protection of the Public and the Environment," dated $1 / 7 / 93$.

7) DOE Order 5400.1, "General Environmental Protection Program," dated 6/29/90.

8) DOE Order 5400.3, "Hazardous and Radioactive Mixed Waste Program," dated 2/22/89.

9) 40 CFR 265, "EPA Interim Status Standards for Owners and Operators of Hazardous Waste Facilities," dated 8/31/93.

10) DOE/EH-0135, "Performance Objectives and Criteria for Technical Safety Appraisals at Department of Energy Facilities and Sites," dated June 1990.

The following reference documents were considered, but not used.

1) Washington Administrative Code (WAC) 246-250, "Radioactive Waste--Land Disposal."

2) NUREG-1199, "Standard Format and Content of a License Application for a Low-Level Radioactive Waste Disposal Facility," dated January, 1987. 


\section{WESTINGHOUSE HANFORD COMPANY}

\section{REQUIREMENTS}

\section{IDENTIFICATION}

\section{DOCUMENT}

FACILITY:

HIGH LEVEL WASTE STORAGE TANK FARMS/242-A EVAPORATOR
FUNCTIONAL AREA:

Research and Development and

Experimental Activities

\section{REVISION 0}




\section{REQUIREMENTS IDENTIFICATION DOCUMENT \\ HIGH LEVEL WASTE STORAGE TANK FARMS \\ Research and Development and Experimental Activities \\ Revision 0}

\section{TABLE OF CONTENTS}

15.0 RESEARCH AND DEVELOPMENT AND EXPERIMENTAL ACTIVITIES $\ldots \ldots \ldots \ldots \ldots$

15.1 PROGRAM MANAGEMENT $\ldots \ldots \ldots \ldots \ldots \ldots \ldots \ldots$

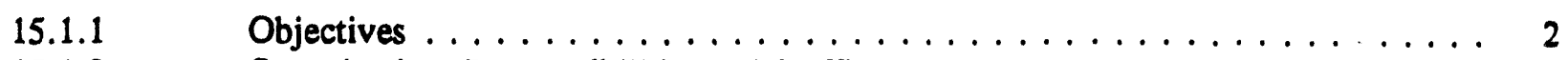

15.1.2 Organization, Responsibilities and Staffing $\ldots \ldots \ldots \ldots \ldots$

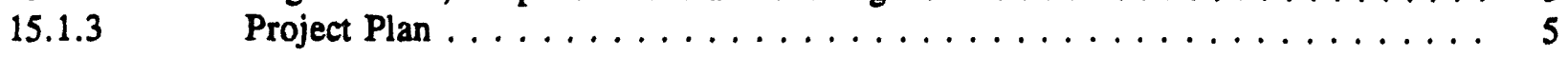

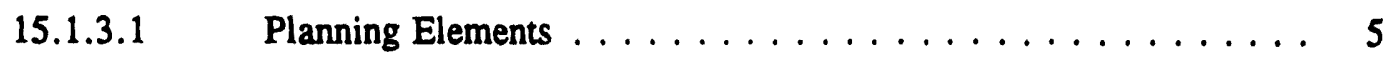

15.1.3.2 Technical Plan $\ldots \ldots \ldots \ldots \ldots \ldots \ldots \ldots$

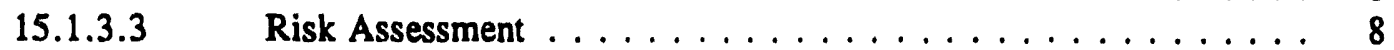

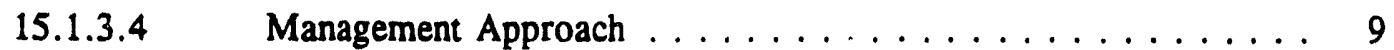

15.1.3.5 Acquisition Strategy . . . . . . . . . . . . . . . . . 10

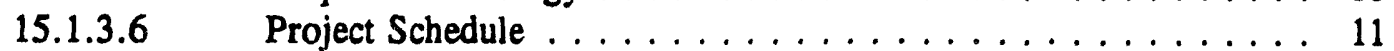

15.1.3.7 Project Resource Plan . . . . . . . . . . . . . . . 11

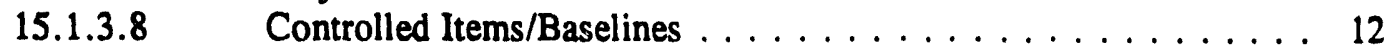

15.1.3.9 Work Breakdown Structure . . . . . . . . . . . . . . . 12

15.1.3.10 Project Charter . . . . . . . . . . . . . . . . . . . 13

15.1.3.11 Project Changes $\ldots \ldots \ldots \ldots \ldots \ldots$

15.1.4 Project Management Plan $\ldots \ldots \ldots \ldots \ldots \ldots \ldots$

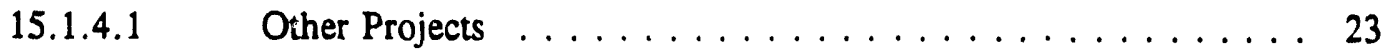

15.2 FACILITIES AND EQUIPMENT $\ldots \ldots \ldots \ldots \ldots \ldots \ldots \ldots \ldots \ldots$

15.3 INVENTORY CONTROL AND ACCOUNTABILITY $\ldots \ldots \ldots \ldots \ldots \ldots$

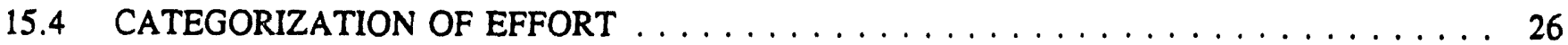

15.4.1 Program/Project Designation $\ldots \ldots \ldots \ldots \ldots \ldots \ldots \ldots \ldots \ldots \ldots$

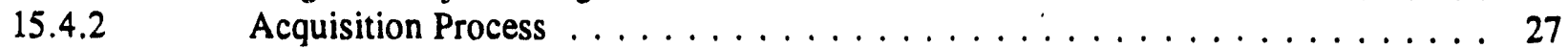

15.4.3 Project Approvals And Execution $\ldots \ldots \ldots \ldots \ldots \ldots$

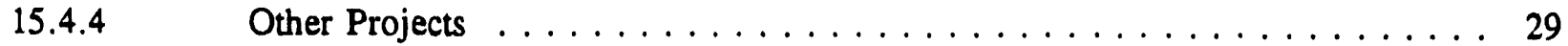

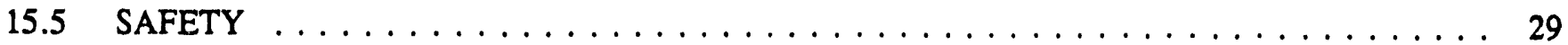

15.6 SAFETY REVIEW COMMITTEE $\ldots \ldots \ldots \ldots \ldots \ldots \ldots \ldots \ldots \ldots$

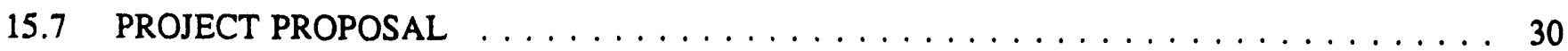

15.8 CONCEPT AND FEASIBILITY STUDY $\ldots \ldots \ldots \ldots \ldots \ldots \ldots \ldots \ldots$

15.8.1 State-Of-The-Art Evaluations $\ldots \ldots \ldots \ldots \ldots \ldots \ldots \ldots \ldots \ldots$

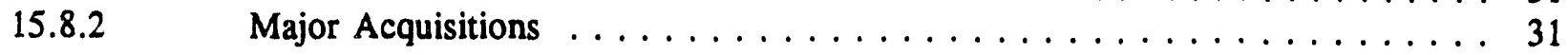




\section{REQUIREMENTS IDENTIFICATION DOCUMENT \\ HIGH LEVEL WASTE STORAGE TANK FARMS \\ Research and Development and Experimental Activities \\ Revision 0}

15.9 PLANNING AND ESTIMATING $\ldots \ldots \ldots \ldots \ldots \ldots \ldots \ldots \ldots \ldots \ldots$

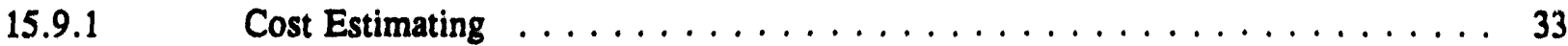

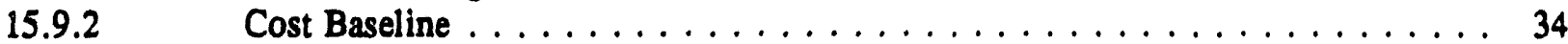

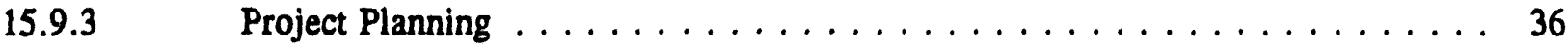

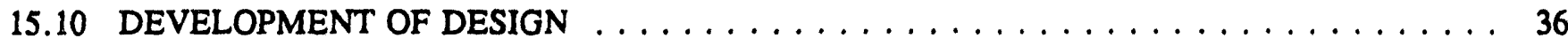

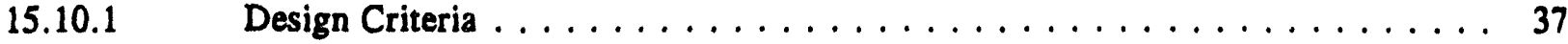

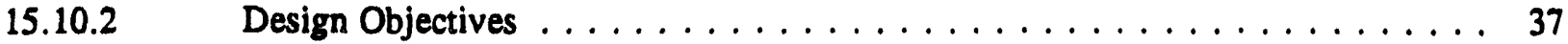

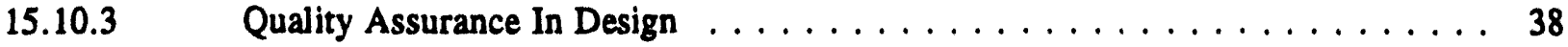

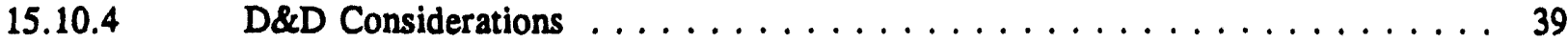

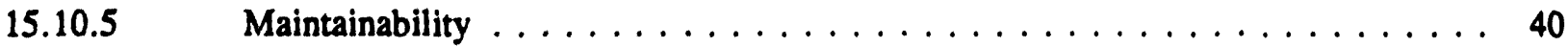

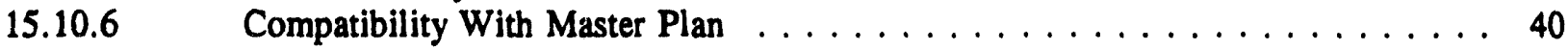

15.10.7 ES\&H Considerations $\ldots \ldots \ldots \ldots \ldots \ldots \ldots \ldots \ldots \ldots \ldots$

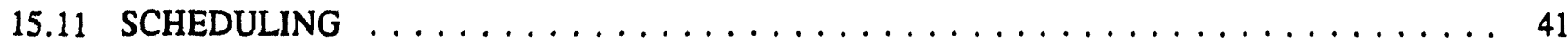

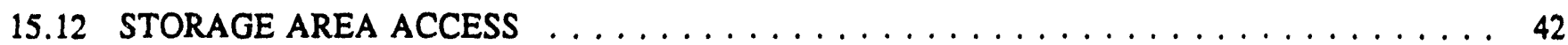

15.12.1 Construction Management $\ldots \ldots \ldots \ldots \ldots \ldots \ldots \ldots \ldots \ldots \ldots$

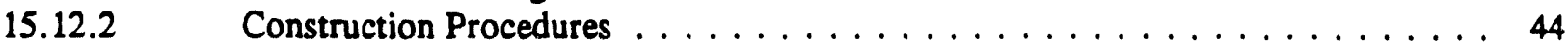

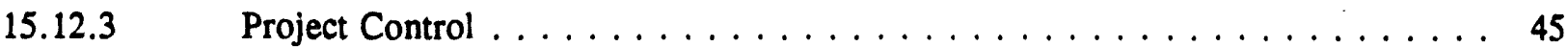

15.12.3.1 Performance Measurement . . . . . . . . . . . . . 45

15.12.3.2 Project Reporting . . . . . . . . . . . . . . . . . 45

15.12.3.3 Special Requirements . . . . . . . . . . . . . . . . 46

15.12.3.4 Project Management Plan . . . . . . . . . . . . . . . 46

15.12.3.5 Cost And Schedule Control . . . . . . . . . . . . . . 46

15.13 CONDUCT OF R\&D/EA PROGRAM $\ldots \ldots \ldots \ldots \ldots \ldots \ldots \ldots$

15.13.1 Test And Evaluation Plan $\ldots \ldots \ldots \ldots \ldots \ldots \ldots \ldots \ldots$

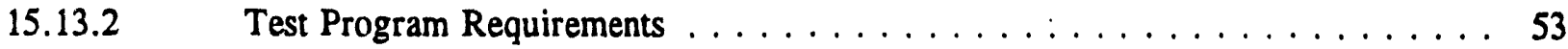

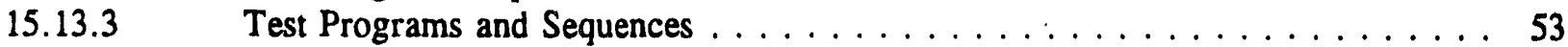

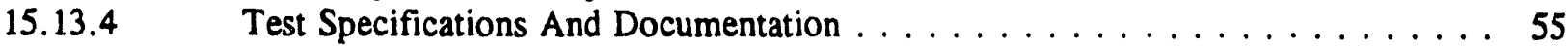

15.13.5 Records $\ldots \ldots \ldots \ldots \ldots \ldots \ldots \ldots \ldots \ldots \ldots \ldots \ldots$

15.14 REVIEW AND EVALUATION OF RESULTS $\ldots \ldots \ldots \ldots \ldots \ldots \ldots \ldots$

15.15 UTILIZATION OF RESULTS $\ldots \ldots \ldots \ldots \ldots \ldots \ldots \ldots \ldots \ldots$

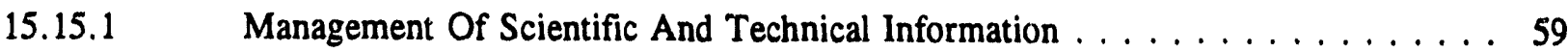

15.15.2 Submission Of Scientific Or Technical Information $\ldots \ldots \ldots \ldots \ldots$

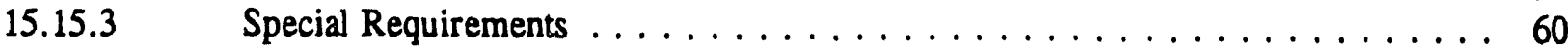

15.16 DISMANTLING AND DISPOSITION $\ldots \ldots \ldots \ldots \ldots \ldots \ldots \ldots$ 


\section{REQUIREMENTS IDENTIFICATION DOCUMENT \\ HIGH LEVEL WASTE STORAGE TANK FARMS \\ Research and Development and Experimental Activities \\ Revision 0}

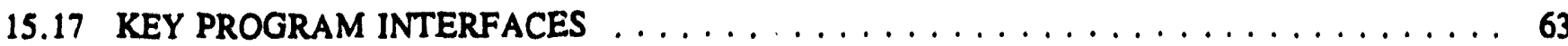

15.17.1 Configuration Management $\ldots \ldots \ldots \ldots \ldots \ldots$

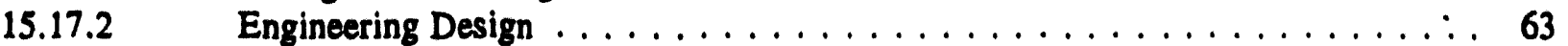

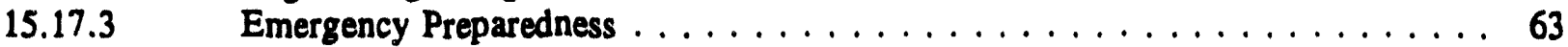

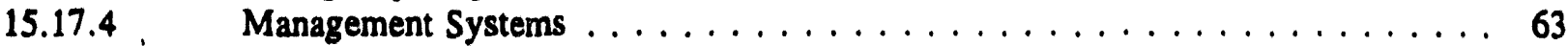

15.17.5 Occupational Safety and Health $(\mathrm{OSH}) \ldots \ldots \ldots \ldots \ldots \ldots$

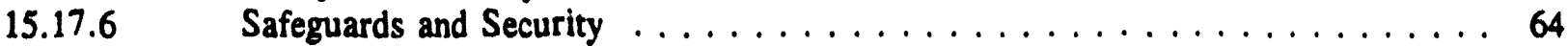

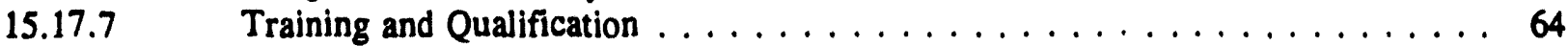




\section{REQUIREMENTS IDENTIFICATION DOCUMENT HIGH LEVEL WASTE STORAGE TANK FARMS \\ Research and Development and Experimental Activities \\ Revision 0}

\subsection{RESEARCH AND DEVELOPMENT AND EXPERIMENTAL ACTIVITIES}

\section{INTRODUCTION}

The Research and Development and Experimental Activities (R\&D/EA) Functional Area encompasses the programmatic controls that should be applied for conducting R\&D/EA activities at DOE facilities. This area covers activities ranging from one-of-a-kind bench-top experiments to routine tests, as well as major R\&D projects that may require construction of a large scale test facility as a demonstration project and extend over long periods of time. R\&D and EA activities, in general, differ in scope (size, duration, manpower, expenditure). Regardless of the scope or complexity of a given project, the same programmatic processes apply to either R\&D or EA activities. A R\&D program may consist of or include a number of EA projects. This Functional Area applies to R\&D and EA projects at existing facilities, including modified facilities, and at new facilities to be designed and constructed for specific programs.

This Requirements Identification Document (RID) describes the programmatic requirements as defined in relevant DOE Orders, regulations, industry codes/standards, industry guidance documents and, as appropriate, good industry practices. The definition of a program as specified by this document is intended to address Defense Nuclear Facilities Safety Board Recommendations 90-2 and 91-1, which call for the strengthening of DOE weapons complex activities through the identification and application of relevant standards that supplement or exceed requirements mandated by DOE Orders.

This RID is intended as a "Facility Specific RID" focused primarily on R\&D/EA activities defined by the statutory category of Science and Technology as described by DOE Order 4700.1. This RID applies to all activities performed at or in conjunction with both standard and non-standard operational practices and procedures of the Tank Farms Facilities and Operations.

This RID applies to the activities, personnel, structures, systems, components, and programs involved in executing the mission of the Tank Farms. The physical boundaries within which the requirements of this RID apply are the Single-Shell Tank Farms, Double-Shell Tank Farms, 242-A Evaporator-Crystallizer, 242-S and T Evaporators, the Liquid Effluent Retention Facility, the Purgewater Storage Facility, and all interconnecting piping, valves, instrumentation, and controls. Also included are all piping, valves, instrumentation, and controls up to and including the most remote valve under Tank Farms' control at any other Hanford Site facility having an interconnection with Tank Farms. The boundary of the structures, systems, components, and programs to which this RID applies is defined by those that are dedicated to and/or under the control of the Tank farms.

The R\&D/EA Functional Area covers programs conducted at DOE facilities to which the other functional areas also apply. Depending on the specific type of the R\&D/EA effort, the elements of this Functional Area and the other functional areas will be implemented using a graded approach commensurate with the R\&D/EA efforts. 


\section{REQUTREMENTS IDENTIFICATION DOCUMENT HIGH LEVEL WASTE STORAGE TANK FARMS Research and Development and Experimental Activities Revision 0}

\section{PROGRAM MANAGEMENT}

It is DOE's stated policy to manage all projects in accordance with DOE Order 4700.1: This order provides instnictions, formats, and procedures to implement the project management syatem. The degree of formality and documentation required are significantly greater for Major System Acquisitions (MSA) and major projects, but this fact does not lessen the responsibility for proper planning and execution of any project. Acquisition Executives, Program Secretarial Officers and Heads of Field Elements are mandated to ensure that the project management system is implemented at a proper level in all projects. DOE's Project Management System (PMS) was established to "... provide implementing instructions, formats, and procedures, and to wet forth the principles and requirements which govern the development, approval, and execution of DOE's outlay program acquisitions... ", which includes R\&D/EA activities ranging from ono-of-a-kind bench-top experiments will, to routine tests, to major R\&D projocts. Although R\&D and EA activities that may be implemented at Tank Farms Facilities will, in general, differ in scope (size, duration, manpower, expenditure), the same PMS programmatic processes apply in the planning, budgeting, execution and review. The general aspects of management, policy, staffing, and training are covered in the Management Systems Functional Ares.

\section{Qbiectives}

MSAs, major projects and other projects have to do with substance, not intent. In other words, all projects must be managed; the extent and formality of that management is the only issue." Due to the inherent characteristics of R\&D/EA activities, the basic tenets of project management are more focused in this functional area than any of the others.

The specific objectives of the Project Management System are summarized as follows:

(1) Ensure ail projects are based on clearly defined missions and mission analyses and are developed with clear time-phased goals and objectives that support program requirements.

(2) Ensure proper coordination by all appropriate line and staff elements beginning with program or project inception.

(3) Provide a basis for determining priorities among programs and projects, and, in turn, relate these to various levels of resource availability.

(4) Promote project execution which achieves technical, schedule and cost objectives. Technical objectives include safeguards and security, environment, health, safety, quality assurance and all programmatic aspects.

(5) Avoid commitment of major resources prior to adequate project definition.

(6) Provide an overall plan for project execution including evaluations of project progress in relation to specific milestones. This plan should also identify the required Government staffing as well as the responsibility and authority of project and matrix staff.

(7) Provide visibility on all key decisions and timely feedback for all levels of management, and maintain accountability and traceability of management decisions through and across all levels of the organization with the minimal amount of procedures and paperwork.

(8) Centralize authority for project approval and for allocation of resources, and assure line 


\section{REQURREMENTS IDENTIFICATION DOCUMENT \\ HUGH LEVEL WASTE STORAGE TANK FARMS \\ Research and Development and Experimental Activities}

Revision 0

menagement authority for project execution and the utilization of recourcos in that execution.

(9) To asoure preparation of well planned budgets.

Oreanization, Responstbillties and Stamng

DOE's project maangement system is a structured approach to managemeat in which autbority, responsibility, and accountability are vested in a single individual to provide the detailed planning, organizing, directing, and controlling of all activitias leading to the successful execution of the project. It is the inteat of the DOE to place authority and reaponsibility for conducting R\&D/EA programs/activities at Tank Farms Facilities at the appropriate managemeat level commensurate with the project offort.

\section{SITE REQUTREMENT SOURCE: DOEA700.1 Chapter I.A.1.a.[2]}

"He or she is responsible for ensuring that the baselines established in that plan are followed to the maximum extent possible."

\section{SITE REQUUREMENT SOURCE: DOEA700.1 Chapter I.A.1.b.[1]}

"The contractor's planning efforts must coincide with those of the Department."

\section{SITE REQUIREMENT SOURCE: DOEA700.1 Chapter I.A.1.b.[2]}

"Part of the establishment of the contractual agreement requires inclusion of a mutual understanding of how the contractor will measure project performance so that the DOE project management plan will reflect that dats."

\section{SITE REQUTREMENT SOURCE: DOEA700.1 Chapter I.A.1.b.[3]}

"These agreed-to plans then become the project manager's mechanisms for directing and controlling the project."

\section{STTE REQUIREMENT SOURCE: DOEA700.1 Chapter I.B.1.b.[1]}

"The program manager is responsible for attaining program góals within a mission area assignment and concentrates on assimilation of all aspects of the program into a single entity."

\section{SITE REQUIREMENT SOURCE: DOEA700.1 Chapter I.B.4.C.[3]}

"In updating the project plan, the project manager should describe the status of technology as it relates to the project. Then, as the project matures, early warning of potential deficiencies in technology readiness should be highlighted in the project manager's status reports."

SITE REQUIREMENT SOURCE: DOEA700.1 Chapter I.C. 5.e.(1)[3]

"The program organizations are responsible for assuring that overall requirements are fulfilled in the areas of environment, technical performance, scope, safety, quality assurance, cost, schedule, and operational environmental safety and health." 


\section{REQUTREMENTS IDENTIFICATION DOCUMENT \\ HIGH LEVEL WASTE STORAGE TANK FARMS \\ Research and Development and Experimental Activities \\ Revision 0}

\section{STTE REQUREMENT SOURCE: DOEA700.1 Chapter 1.C. 7.a.[2]}

"Day-to-day activities withio the scope and charter threaholds and milestones will normally flow between the project manager and the program manager."

\section{SITE REQUIREMENT SOURCE: DOEA700.1 Chapter I.C. 7.a.[3]}

"The project manager will unully be dedicated full time to the major syatem acquisition or mujor project; bowever, on other projects the same project manager may have authority and responsibility for more than one project."

\section{SITE REQUTREMENT SOURCE: DOEA700.1 Chapter I.C. 7.b.( 3)}

"The project manager is responsible for actions indicated below: Reporting will be carried out in accordance with the project management plan and this Order."

\section{SITE REQUTREMENT SOURCE: DOEA700.1 Chapter 1.C. 7.b.( 4)}

"The project manager is responsible for actions indicated below: Quality Assurance. Procedures in the management of the project shall be established."

\section{SITE REQUIREMENT SOURCE: DOEA700.1 Chapter I.C. 7.b.( 5)}

"The project manager is responsible for actions indicated below: The Head of the Field Element will provide necessary support to the project manager to fulfill administrative responsibilities associated with the project."

SITE REQUIREMENT SOURCE: DOEA700.1 Chapter I.C. 7.b.( ๑)[1]

"The project manager is responsible for actions indicated below: The project manager shall initiate all procurement actions necessary for execution of the project."

\section{SITE REQUIREMENT SOURCE: DOEA700.1 Chapter I.C. 7.b.( 7)}

"The project manager is responsible for actions indicated below: The project manager shall oversee design review, construction review, snd construction management activities related to the project."

\section{SITE REQUIREMENT SOURCE: DOEA700.1 Chapter I.C. 7.b.( 8)[1]}

"The project manager is responsible for actions indicated below: Management of project finances including contingency."

\section{SITE REQUTREMENT SOURCE: DOEA700.1 Chapter I.C. 7.b.( 9)[1]}

"The project manager is responsible for actions indicated below: Preparation and execution of a complete test plan to assure full technical performance capabilities of the project." 


\section{REQUIREMENTS IDENTIFICATION DOCUMENT HIGH LEVEL WASTE STORAGE TANK FARMS Research and Development and Experimental Activities Revision 0}

\section{1 .3}

The project plan describes the project and establishes project baselines against which overall progress of the project and the effectivenees of its management ahall be measured. For major projects to be conducted at Tank Farms Facilities, the plan will guide project execution and clearly sets forth the esesential elements of the project. At key decision points for MSAs and major projects, current project plans become a key part of the Acquisition Executive decision-making, the project's mission need is reexamined, and alternatives for executing the next phase aro presented to the Acquisition Executive.

\section{SITE REQUTREMENT SOURCE: DOEA700.1 Attachment II-2.1.[4]}

"The project plan shall be maintained curreat to incorporate the Acquisition Executive decisions to accurately serve as the projoct baseline document."

\section{SITE REQUTREMENT SOURCE: DOEA700.1 Attachment II-2.1.[5]}

"The preparation of the project plan shall be the responsibility of the Program Manager working in cooperation with the Project Manager."

\section{Planning Elements}

The project plan is intended to be a definitive document, no more than 25 pages in length (excluding attachments). In the early stage of a project, the project plan is focused more on objectives, technical plan, management approsch, acquisition strategy, and documenting initial costs schedule, and scope baselines. For larger projects, once the project is well underway, adjustments are made, as appropriate, to the technical plan, management approach, and acquisition strategy; normally these will not change during the remainder of the project. The project manager defines the cost and schedule and focuses on technical objectives, performance, and the test planning for the project. The project plan is then tailored to the needs of the particular project considering the phase of its acquisition strategy, size, complexity, sensitivity, and particular project characteristics. Redundant specification or expression of data is to be avoided or minimized to the extent practical.

Satisfactory management of the project in accordance with the project plan, including the project management charter, is accomplished through independent assessment of regular reports on project status, progress, problems, and variances provided to Headquarters management by the project manager. In turn, Heads of Field Elements have the responsibility to coordinate and integrate all necessary in-house and outside administrative and technical support to moet project objectives and requirements which are developed in detail in the Project Niaragement Plan.

\section{SITE REQUIREMENT SOURCE: DOEA700.1 Attachment II-2.1.[1]}

"The project plan describes the project and establishes approved project baselines against which overall progress of the project and the effectiveness of its management shall be measured."

\section{SITE REQUIREMENT SOURCE: DOEA700.1 Attachment II-2.1.[2]}

"The plan guides project execution and clearly sets forth the essential elements of the project." 


\section{REQUIREMENTS IDENTIFICATION DOCUMENT \\ HIGH LEVEL WASTE STORAGE TANK FARMS \\ Research and Development and Experimental Activities \\ Revision 0}

SITE REQUIREMENT SOURCE: DOEA700.1 Attachment II-2.1.[3]

"At key decision points for MSA's and major projects, updated project plans become a key part of the Acquisition Executive decision cycle, and the project's mission need is reexamined and alternatives for executing the next phase are presented to the Acquisition Executive."

\section{SITE REQUIREMENT SOURCE: DOEA700.1 Attachment II-2.2. [1]}

"The project plan should be a definitive document no more than 25 pages in length."

SITE REQUIREMENT SOURCE: DOE4700.1 Attachment II-2.2. [2]

"The project manager shall define the cost and schedule and shall focus on technical objectives, performance, and the test planning for the project."

\section{SITE REQUIREMENT SOURCE: DOE4700.1 Attachment II-2.2. [3]}

"The project plan shall be tailored to the needs of the particular project considering the phase of its acquisition strategy, size, complexity, sensitivity, and particular project characteristics."

SITE REQUIREMENT SOURCE: DOEA700.1 Attachment II-2.2.a.[3]

"The data and information included must provide reaffirmation of the Justification of Mission Need that was initially approved at Key Decision 0."

\section{SITE REQUIREMENT SOURCE: DOEA700.1 Attachment II-2.2.a.[7]}

"Redundant specification or expression of data shall be avoided or minimized to the extent practical."

\section{SITE REQUIREMENT SOURCE: DOEA700.1 Chapter I.C. 9.[2]}

"The project organization will be summarized in the project plan and detailed in the project management plan."

\subsubsection{Technical Plan}

The Technical Plan describes the planned accomplishments of the project and will be developed according to the following DOE recommended requirements:

(1) Documentation of technical objectives in quantitative terms

(2) Description of Technology Readiness

(3) Discussion of Technological/Engineering/Processes

(4) Description of alternatives, and the basis for selection

(5) Description of each phase of the project and products to be developed

(6) Summary of the Project Work Breakdown Structure 


\section{REQUIREMENTS IDENTIFICATION DOCUMENT \\ HIGH LEVEL WASTE STORAGE TANK FARMS \\ Research and Development and Experimental Activities \\ Revision 0}

(7) Flow/logic diagram illustrating critical project elements, sequencing and interdependencies

\section{SITE REQUIREMENT SOURCE: DOE4700.1 Attachment II-2.2.b.(1)}

"Expanding on the technical objectives, briefly describe what is to be developed or constructed. This description shall refer to the location (when construction is involved) and the major systems or elements of the project or facility."

\section{SITE REQUIREMENT SOURCE: DOEA700.1 Attachment II-2.2.b.(2)[1]}

"Describe the status of technology or the "technology readiness" for implementing the project. Include in this discussion a description of any ongoing or planned supporting development work on which the project is dependent and which, therefore, is part of the project."

\section{SITE REQUIREMENT SOURCE: DOEA700.1 Attachment II-2.2.b.(3)[1]}

"Either integrate or follow the above discussion with a description of the specific scientific, technological, or engineering approaches or processes to be used in meeting the performance objectives."

\section{SITE REQUIREMENT SOURCE: DOE4700.1 Attachment II-2.2.b.(3)[2]}

"For projects early in design and development, emphasis shall be placed on alternative concepts, design, or technical approaches being considered or pursued."

SITE REQUIREMENT SOURCE: DOE4700.1 Attachment II-2.2.b.(3)[3]

"For more mature projects, the development paths, critical subsystems, and test and verification procedures shall be described."

\section{SITE REQUIREMENT SOURCE: DOEA700.1 Attachment II-2.2.b.(4)}

"For projects pursuing alternative design or technical approaches, briefly describe each alternative and the basis for selection of an alternative."

SITE REQUIREMENT SOURCE: DOEA700.1 Attachment II-2.2.b.(5)[1]

"Describe each phase of the project including the work to be accomplished and products developed."

SITE REQUIREMENT SOURCE: DOE4700.1 Attachment II-2.2.b.(5)[2]

"In this discussion, indicate the major project events, technical activities, and decision points and authority that occur during each phase of the acquisition process."

SITE REQUIREMENT SOURCE: DOEA700.1 Attachment II-2.2.b.(6)[1]

"A work breakdown structure chart is mandatory and shall be summarized in this section and included as an attachment." 


\section{REQUIREMENTS IDENTIFICATION DOCUMENT \\ HIGH LEVEL WASTE STORAGE TANK FARMS \\ Research and Development and Experimental Activities \\ Revision 0}

\section{SITE REQUIREMENT SOURCE: DOE4700.1 Attachment II-2.2.b.(0)[2]}

"The work breakdown structure should be product oriented and present the products or work elements of the project down to level three."

SITE REQUIREMENT SOURCE: DOEA700.1 Attachment II-2.2.b.(0)[3]

"This breakdown of the project shall conform to the manner in which the work shall be performed (including environmental work) and in which project cost and schedule are controlled and reported."

\section{SITE REQUIREMENT SOURCE: DOE4700.1 Attachment II-2.2.b.(7)}

"For complex projects comprised of several major elements, include a flow or logic diagram that illustrates project element sequencing and interdependencies."

\section{Risk Assessment}

Assessment of project risk requires identification of critical systems, subsystems, and other factors in order to focus work and resolution. Types of risks that shall be addressed are technical, schedule, cost, others such as safeguards and security at all phases, loan guarantee, environmental, health, safety, regulatory, utility, and institutional impediments that are not covered elsewhere. In addressing each risk, the following information is required:

\section{SITE REQUIREMENT SOURCE: DOEA700.1 Attachment II-2.2.c. [3]}

"Types of risks that shall be addressed are technical, schedule and cost, and other risks such as loan guarantee risks and environmental, health, safety, regulatory, and utility risks, and institutional impediments that are not covered in other sections."

\section{SITE REQUIREMENT SOURCE: DOE4700.1 Attachment II-2.2.c.(1)}

"In addressing each risk, the following information is required: The assessed level of risk (high, moderate, low);"

\section{SITE REQUIREMENT SOURCE: DOE4700.1 Attachment II-2.2.c.(2)}

"In addressing each risk, the following information is required: The basis for this assessment (reliability, availability, and maintainability analyses; study results; proven or unproven technology; well established or unproven construction procedures; "

\section{SITE REQUIREMENT SOURCE: DOE4700.1 Attachment II-2.2.c.(3)}

"In addressing each risk, the following information is required: The critical project elements contributing to the risk; "

SITE REQUIREMENT SOURCE: DOE4700.1 Attachment II-2.2.c.(4)

"In addressing each risk, the following information is required: Implications of the risk;" 


\section{REQUIREMENTS IDENTIFICATION DOCUMENT \\ HIGH LEVEL WASTE STORAGE TANK FARMS \\ Research and Development and Experimental Activities \\ Revision 0}

\section{SITE REQUIREMENT SOURCE: DOEA700.1 Attachment II-2.2.c.(5)}

"In addressing each risk, the following information is required: Activities or altematives planned to minimize the risk;"

SITE REQUIREMENT SOURCE: DOEA700.1 Attachment II-2.2.c.(0)[1]

"In addressing each risk, the following information is required: The stage of the project in which the risk exists."

SITE REQUIREMENT SOURCE: DOEA700.1 Attachment II-2.2.c.(0)[2]

"In this case, the discussion shall identify any risks that are evident and indicate when the risk assessment for the project shall be developed."

\section{Management Approach}

This section addresses the organizational responsibilities, decision delegations, other management arrangements, and management control systems under which the project shall be carried out. Emphasis is placed on the extent of the project manager's responsibility for total project funds and work effort. Accordingly, when field office matrix support is used by the project manager to review or monitor some aspects of project funded work, that management relationship shall be explained.

\section{SITE REQUIREMENT SOURCE: DOEA700.1 Attachment II-2.2.d. [3]}

"Emphasis shall be placed on the extent of the project manager's responsibility for total project funds and work effort."

SITE REQUIREMENT SOURCE: DOEA700.1 Attachment II-2.2.d. [4]

"Accordingly, when field office matrix support is used by the project manager to review or monitor some aspects of project funded work, that management relationship shall be explained."

\section{SITE REQUIREMENT SOURCE: DOE4700.1 Attachment II-2.2.d.(1)}

"Identify the Headquarters program office and division to which the project is assigned and the field organization responsible for project management. "

\section{SITE REQUIREMENT SOURCE: DOEA700.1 Attachment II-2.2.d.(2)}

"Identify the project manager by name in the text and indicate the actual or planned approval dates for the project management plan. If the project manager has not yet been selected, indicate when selection is expected to be made and the person responsible for the project until the selection is made."

SITE REQUIREMENT SOURCE: DOEA700.1 Attachment II-2.2.d.(3)

"Depict all participating organizations (DOE, major contractors, and others) and their 


\section{REQUIREMENTS IDENTIFICATION DOCUMENT \\ HIGH LEVEL WASTE STORAGE TANK FARMS \\ Research and Development and Experimental Activities \\ Revision 0}

responsibilities on a project organization chart which shall be included as an attachment. Include names of the Headquarters program manager and the designated project manager on the chart."

\section{SITE REQUIREMENT SOURCE: DOEA700.1 Attachment II-2.2.d.(4)}

"Where there are industry or utility partners, identify the partners and describe the management relationships with them and their role in management and implementation of the project. Also refer to existing agreements (cost sharing and other) with them or the status of agreements still to be negotiated."

\section{SITE REQUIREMENT SOURCE: DOEA700.1 Attachment II-2.2.d.(5)}

"In discussing the items above, clearly identify decision delegations and the responsibilities of each of the key individuals and supporting organizations."

SITE REQUIREMENT SOURCE: DOEA700.1 Attachment II-2.2.d.(6)

"Identify and discuss project transition responsibilities and areas."

SITE REQUIREMENT SOURCE: DOEA700.1 Attachment II-2.2.d.(7)

"For demonstration projects, indicate how disposition of the plant shall be determined at the conclusion of the demonstration phase of the acquisition process or termination at the convenience of the Government."

\section{SITE REQUIREMENT SOURCE: DOE4700.1 Attachment II-2.2.d.(8)}

"If there will be site cleanup problems after conclusion of project operations, indicate how these needs shall be met."

\section{SITE REQUIREMENT SOURCE: DOEA700.1 Attachment II-2.2.d.(9)}

"Describe the integrated project management control systems...reporting procedures, and data systems which shall be used by the project manager to control costs, schedules, and technical performance based on the work breakdown structures."

\section{Acquisition Strategy}

The acquisition strategy is the underlying conceptual basis for management of a project and reflects the interrelationship of its mission, technical, business, and management objectives. A business strategy group should be used as an advisor to develop the acquisition strategy. Formulation of a strategy should include a description of the means by which the management objectives prescribed for major system acquisitions and major projects, and the planning considerations shall be implemented while assuring consistency with program and project objectives. Key elements involved in an acquisition strategy are: the use of multiphase contracts; sustaining competition; degree of delegation by the Government of coordination, integration, and management responsibility to a contractor; and reliance on private industry. These elements and the others should be fully developed and appropriately utilized in the development of an acquisition strategy. The development of the acquisition strategy for the project should clearly describe the approach that will be used for acquiring the major items of 


\section{REQUIREMENTS IDENTIFICATION DOCUMENT \\ HIGH LEVEL WASTE STORAGE TANK FARMS \\ Research and Development and Experimental Activities \\ Revision 0}

hardware, software, and management support described in the technical plan.

\section{SITE REQUIREMENT SOURCE: DOEA700.1 Attachment II-2.2.e. [1]}

"The project plan format and the information it shall contain are described below: Acquisition Strategy."

\section{SITE REQUIREMENT SOURCE: DOEA700.1 Attachment II-2.2.e. [3]}

"A business strategy group should be used as an advisor to develop the acquisition strategy."

SITE REQUIREMENT SOURCE: DOEA700.1 Attachment II-2.2.e. [4]

"This section shall include a description of the means by which the management objectives prescribed for major system acquisitions and major projects, and the planning considerations shall be implemented while assuring consistency with program and project objectives."

\section{SITE REQUIREMENT SOURCE: DOEA700.1 Attachment II-2.2.e. [7]}

"This section shall briefly summarize the acquisition strategy developed for the project and describe the approach that shall be used for acquiring the major items of hardware, software, and management support described in the technical plan section."

\section{SITE REQUIREMENT SOURCE: DOEA700.1 Attachment II-2.2.e.(2)}

"Include in this summary a description of how the management concepts relate to technical, business, resource, and other aspects of the project."

\section{SITE REQUIREMENT SOURCE: DOEA700.1 Attachment II-2.2.e.(3)}

"Indicate whether or not a project manager, construction manager, or other integrating contractor, including Government management and operating contractors, will be used in the project and the extent to which such contractor will be responsible for implementing the project acquisition strategy."

$\underline{15.1 .3 .6}$

$\underline{15.1 .3 .7}$

\section{Project Schedule}

The project plan should include a one-paragraph statement that refers to the project schedule as an attachment. It should also include any qualifying statements. The schedule attachment must be consistent with the project work breakdown structure (WBS) and contain, as a minimum, the schedule for project WBS elements down to and including level 2, including the following:

\section{Project Resource Plan}

The project plan shall include a resources plan as an attachment: any qualifying statements must be presented, in addition to the total project cost. The resources plan should also indicate the projected total manpower level of the project office management staff (DOE, contractor and other personnel). Life cycle cost considerations for all resources impacting total project cost, such as energy efficient new building design features, selection of materials and systems for maintainability, and selection of the most cost effective utility services to meet program requirements, etc., shall be included. These cost considerations shall address all costs for 


\section{REQUIREMENTS IDENTIFICATION DOCUMENT HUGH LEVEL WASTE STORAGE TANK FARMS Research and Development and Experimental Activities \\ Revision 0}

construction and operation of the project, including the utilities requirements (e.g., electric, water, steam, gas) and maintenance requirements, as appropriate. The resource chart shall be consistent with the WBS and include:

\section{SITE REQUIREMENT SOURCE: DOEA700.1 Attachment II-2.2.g. [3]}

"This section also indicates the projected total manpower level of the project office management staff (DOE, contractor and other personnel)."

\section{SITE REQUIREMENT SOURCE: DOEA700.1 Attachment II-2.2.g. [4]}

"Life cycle cost considerations for all resources impacting total project cost, such as energy efficient new building design features, selection of materials and systems for maintainability, and selection of the most cost effeciive utility services to meet program requirements, etc., shall be included in this section."

\section{SITE REQUIREMENT SOURCE: DOE4700.1 Attachment II-2.2.g. [5]}

"These cost considerations shall consider all costs for construction and operation of the project, including the utilities requirements (e.g., electric, water, steam, gas) as appropriate."

\section{Controlled Items/Baselines}

Controlled baselines are cost, schedule, and scope (technica!). The baselines must be presented in a format similar to that depicted in DOE Order 4700.1, Figure IIl-15, which defines both the baselines and the approval authority for the baselines. Thresholds for change control authority of the baselines shall be presented in a format similar to that depicted in Figure III-16 which defines the thresholds and approval authority for changes to the baselines identified in Figure III-15].

\section{SITE REQUIREMENT SOURCE: DOEA700.1 Attachment II-2.2.h. [3]}

"The baselines shall be presented in a format similar to that depicted in Figure III-15 which defines both the baselines and the approval authority for the baselines."

\section{Work Breakdown Structure}

Much of the planning, execution, and control of DOE projects revolves around the work breakdown structure (WBS). The WBS is a graphic representation that completely defines the project by relating elements of work to each other and to the end product. It is the prime tool which DOE uses in performance of project responsibilities. A complete guide to the development of a WBS is contained in DOE/MA-0040. Figure II-3 of DOE Order 4700.1 illustrates a typical WBS. The individual products specified in the WBS are termed "elements." Each element is a discrete portion of the WBS, comprising either an item of hardware, service, or data. Descending levels provide increasingly detailed definition of the end objective. The number of levels depends on the scope and complexity of the individual project and the degree of control it warrants. 


\section{REQUIREMENTS IDENTIFICATION DOCUMENT \\ HIGH LEVEL WASTE STORAGE TANK FARMS \\ Research and Development and Experimental Activities \\ Revision 0}

SITE REQUIREMENT SOURCE: DOEA700.1 Chapter II.B.2.[1]

"The project manager is responsible for preparation of the project WBS."

SITE REQUIREMENT SOURCE: DOEA700.1 Chapter II.B.2.[3]

"Contractors, in turn develop a contract WBS to conform to their support of the project."

SITE REQUIREMENT SOURCE: DOEA700.1 Chapter II.B.3.f.[2]

"It is not necessary that the WBS level identified for project control purposes (e.g., contract reporting) be the same as that used for configuration management."

SITE REQUIREMENT SOURCE: DOEA700.1 Chapter II.B.3.g.[1]

"The WBS logistic elements should provide the capabilities to support the prime system and its components."

SITE REQUIREMENT SOURCE: DOEA700.1 Chapter II.B.3.g.[2]

"The elements shall reflect the lead time planning needs of the site or test facility."

SITE REQUIREMENT SOURCE: DOEA700.1 Chapter II.B.3.h.[2]

"A test and evaluation element shall be used to obtain or validate test performance data."

SITE REQUIREMENT SOURCE: DOEA700.1 Chapter II.B.3.h.[3]

"This element shall cover the detailed planning, conduct, support, data reduction, and reports from the testing."

\section{SITE REQUTREMENT SOURCE: DOEA700.1 Chapter II.B.3.h.[4]}

"Since testing requires the participation of organizational elements responsible for accomplishing development, reliability, and qualification tests, appropriate supporting elements need to be included."

SITE REQUIREMENT SOURCE: DOEA700.1 Chapter II.B.3.i.[2]

"Following design and the development of a specification tree, the WBS shall be revised to reflect the end product."

\section{Project Charter}

The project charter can be prepared and approved prior to the preparation of the project plan but should be included as part of the plan. The project charter clearly delineates management responsibility, authority, and accountability for the project. It establishes the operational management relationships between Headquarters and field project management organizations. The project charter should contain the information outlined below: 


\section{REQUIREMENTS IDENTIFICATION DOCUMENT \\ HIGH LEVEL WASTE STORAGE TANK FARMS \\ Research and Development and Experimental Activities \\ Revision 0}

SITE REQUIREMENT SOURCE: DOEA700.1 Attachment II-2.2.i. [2]

"The project charter may be prepared and approved prior to the preparation of the project plan but should be included as part of the plan."

SITE REQUIREMENT SOURCE: DOEA700.1 Attachment II-2.2.i. [3]

"The project charter clearly delineates management responsibility, authority, and accountability for the project."

\section{SITE REQUIREMENT SOURCE: DOEA700.1 Attachment II-2.2.i. [4]}

"It establishes the operational management relationships between Headquarters and field project management organizations."

SITE REQUIREMENT SOURCE: DOEA700.1 Attachment II-2.2.i.(1)

"The project charter should contain the information outlined below: The responsible managing organization."

SITE REQUIREMENT SOURCE: DOEA700.1 Attachment II-2.2.i.(2)

"The project charter should contain the information outlined below: The name of the designated project manager and the effective date of assignment."

SITE REQUIREMENT SOURCE: DOEA700.1 Attachment II-2.2.i.(3)

"The project charter should contain the information outlined below: The location of the project management office."

SITE REQUIREMENT SOURCE: DOEA700.1 Attachment II-2.2.i.(4)

"The project charter should contain the information outlined below: The support (including interface coordination) to be furnished to the project manager by other participating

organizations such as other Departmental components."

SITE REQUIREMENT SOURCE: DOE4700.1 Attachment II-2.2.i.(5)

"The project charter should contain the information outlined below: The authorities of the project manager including appropriate references to DOE Orders, acquisition regulations, and other guidelines. "

\section{SITE REQUIREMENT SOURCE: DOE4700.1 Attachment II-2.2.i.(6)}

"The project charter should contain the information outlined below: The reporting channel of the project manager, established to account for the size, complexity, and importance of the project and to eliminate unnecessary layers of authority above the project manager." 


\section{REQUIREMENTS IDENTIFICATION DOCUMENT HIGH LEVEL WASTE STORAGE TANK FARMS \\ Research and Development and Experimental Activities \\ Revision 0}

\section{SITE REQUIREMINT SOURCE: DOEA700.1 Attachment II-2.2.1.(7)}

"The project charter should contain the information outlined below: Special instructions, or delegations of authority, to the project manager for the execution of the approved project."

\section{SITE REQUIREMENT SOURCE: DOEA700.1 Attachment II-2.2.i.(8)}

"The project charter should contain the information outlined below: Special requirements for a transition or termination plan to outline tentatively the conditions under which the project management organization shall phase out or responsibility shall be transferred.

\section{SITE REQUIREMENT SOURCE: DOE4700.1 Attachment II-2.2.i.(9)}

"The project charter should contain the information outlined below:

The staffing positions, including matrix staff, to be provided for project execution."

\subsubsection{Project Changes}

The following requirements will be met for all project plan changes on major system acquisitions and major projects. Field office managers are responsible for change requirements for Other Projects. Such requirements should be consistent with those indicated below.

SITE REQUIREMENT SOURCE: DOEA700.1 Attachment II-3.1.b.

"Only changes approved at the appropriate management level will be incorporated into the Project Plans."

SITE REQUIREMENT SOURCE: DOEA700.1 Attachment II-3.1.c.[1]

"The responsible project ffice will incorporate the approved changes."

SITE REQUIREMENT SOURCE: DOEA700.1 Attachment II-3.1.c.[2]

"Each revised page or attachment to a Project Plan will include the revision number and the date revised."

SITE REQUIREMENT SOURCE: DOEA700.1 Attachment II-3.1.d.(2)

"Each project plan should provide a project change log, as an attachment, which should contain: A list of the pages that were revised and the date"

SITE REQUIREMENT SOURCE: DOEA700.1 Attachment II-3.1.d.(3)

"Each project plan will include a Project Plan Change Log which will contain: The authorizing Baseline Change Proposal number."

SITE REQUIREMENT SOURCE: DOEA700.1 Attachment II-3.1.g.(1)

"The cognizant project office will be responsible for preparing all requested changes." 


\section{REQUIREMENTS IDENTIFICATION DOCUMENT \\ HIGH LEVEL WASTE STORAGE TANK FARMS \\ Research and Development and Experimental Activities \\ Revision 0}

\section{SITE REQUIREMENT SOURCE: DOEA700.1 Attachment II-3.1.g.(2)}

"The cognizant project office will prepare all directed changes."

\section{Project Management Plan}

The project management plan (PMP) is tbr, document which sets forth the plans, organization, and systems that those responsible for managing the project shall utilize. The content and extent of detail of the PMP will vary in accordance with the size and type of project and state of project execution. The plan is developed by the managing organization and approved by the Head of the Field Element following review by the cognizant program office and other offices as deemed appropriate. The plan should be kept current as the project progresses and an annual review of the plan, with appropriate updating of sections, should be made by the managing organization to assure that it is curreat. The document may be of the magnitude as indicated by the requirements listed below, if the effort is a major system acquisition or a major project; or it may be as simple as a memorandum of understanding between the project manager and other interested parties, if the project is small. See Attachment II-5 to DOE Order 4700.1. The content should include the requirements described below. A project management plan is necessary, but it does not have to be elaborate, particularly for less complex R\&D/EA activities. In some instances, a generic PMP may be sufficient. Even if the project is part of a larger one that has its own overall PMP, it is still necessary for managers to have a plan from which to work. The essentials of a PMP are as follows:

a. A summary of the project that can be read by anyone in a few minutes and that will provide an understanding of the essentials of the project. It states briefly what is to be done and may mention the methods and techniques to be used. It lists the deliverable end products in such a way that when they are produced they can be easily identified and compared with the plan.

b. A list of tangible and discrete milestones, identified in such a way that there can be no ambiguity about whether a milestone has been achieved. In general, the number of milestones shall correspond to reasonable dollar portions of the project budget in order to provide adequate monitoring.

c. A Work Breakdown Structure that is detailed enough to provide meaningful identification of all tasks, plus all higher-level work groupings.

d. From the milestone list and the WBS, an activity network that shows the sequence of the elements of the project and how they are related (which ones can be done concurrently, which can start only when another is finished, and so forth). This is more useful than just marking end points on bar charts.

e. Separate budgets and schedules for all the elements of the project that some individual is responsible for. f. An interface plan that shows how the project communicates with the rest of the world, most particularly with the contractor, but also with Departmental line or staff organizations that are involved.

g. An indication of the reporting and review process--what reports are needed, who reviews the project, when, and for what purpose.

h. A list of key project personnel and their assignments in relation to the WBS. Key personnel are those responsible for the various phases of the project. 


\section{REQUIREMENTS IDENTIFICATION DOCUMENT HIGH LEVEL WASTE STORAGE TANK FARMS Research and Development and Experimental Activities Revision 0}

\section{SITE REQUIREMENT SOURCE: DOEA700.1 Attachment II-4.1.[1]}

"The project management plan (PMP) is the document which sets forth the plans, organization, and systems that those responsible for managing the project shall utilize."

\section{SITE REQUIREMENT SOURCE: DOEA700.1 Attachment II-4.1.[2]}

"The plan is developed by the managing organization and approved by the Head of the Field Element following re;iow by the cognizant program office and other offices as deemed appropriate."

\section{SITE REQUIREMENT SOURCE: DOEA700.1 Attachment II-4.1.[3]}

"The plan should be kept current as the project progresses and an annual review of the plan, with appropriate updating of sections, should be made by the managing organization to assure that it is current."

\section{SITE REQUTREMENT SOURCE: DOEA700.1 Attachment II-4.2.a.[2]}

"It should reference other project documentation including the justification for new start, the project plan, which includes the project charter and indicate subsequent plans which are to be developed..."

\section{SITE REQUIREMENT SOURCE: DOE4700.1 Attachment II-4.2.b.(1)}

"The following types of objectives shall be stated: Measurable technical and economic objectives in terms of design criteria or performance capability."

\section{SITE REQUIREMENT SOURCE: DOE4700.1 Attachment II-4.2.b.(2)}

"The following types of objectives shal! be stated: Schedule objectives for major items on the project critical parts showing their relationship to the project summary work breakdown structure elements

\section{SITE REQUIREMENT SOURCE: DOE4700.1 Attachment II-4.2.b.(3)}

"The following types of objectives shall be stated: Cost objectives for work breakdown structure level one, two, and three elements and their relationship to the total project cost provided in the project plan."

\section{SITE REQUIREMENT SOURCE: DOE4700.1 Attachment II-4.2.c.[2]}

"The charts should be comprehensive in scope and at a level of detail consistent with the current project phase of the acquisition cycle, and should show significant project interfaces as well as lines of authority, responsibility, accountability, and communication."

\section{SITE REQUIREMENT SOURCE: DOEA700.1 Attachment II-4.2.c.[3]}

"Definition should be provided of all significant interfaces in the project such as between project geographic locations, functional units, and contractors." 


\section{REQUIREMENTS IDENTIFICATION DOCUMENT \\ HIGH LEVEL WASTE STORAGE TANK FARMS \\ Research and Development and Experimental Activities \\ Revision 0}

SITE REQUIREMENT SOURCE: DOEA700.1 Attachment II-4.2.c.[4]

"Any interface management control techniques that will be utilized should be explained."

\section{SITE REQUIREMENT SOURCE: DOEA700.1 Attachment II-4.2.c.[5]}

"Where there are industry or utility partners, the partners should be identified and the management relationships and their role in management and implementation of the project should be described; also, existing agreements (cost sharing and other) with them or the status of agreements still to be negotiated should be referenced."

\section{SITE REQUIREMENT SOURCE: DOEA700.1 Attachment II-4.2.c.[6]}

"The staffing plans for the project organization should be described in detail; this will include both the present staff organization and future staffing plans, the mix of dedicated project staff, grade levels, and the manpower plan by fiscal year."

\section{SITE REQUIREMENT SOURCE: DOEA700.1 Attachment II-4.2.d.[1]}

"Work Plan. This section should describe in detail what is going to be done and how it should be accomplished in accordance with the project summary work breakdown structure."

\section{SITE REQUIREMENT SOURCE: DOEA700.1 Attachment II-4.2.d.[2]}

"The major subsystems or elements being developed or constructed, relating to the level two and associated level three elements, should be described in detail."

\section{SITE REQUIREMENT SOURCE: DOEA700.1 Attachment II-4.2.d.[3]}

"Summary system descriptions relating project performance requirements and design parameters should be provided."

\section{SITE REQUIREMENT SOURCE: DOEA700.1 Attachment II-4.2.d.[4]}

"Each phase of project activity should be described, including what is to be accomplished in the current and subsequent phases of the acquisition cycle and the products to be developed."

\section{SITE REQUIREMENT SOURCE: DOEA700.1 Attachment II-4.2.d.[5]}

"The technical criteria for project design and construction should be defined including environment, safety and health requirements; codes, standards, and specifications of Federal, State, and local Governments and their agencies; industry and trade organizations; and intermediate technical goal and milestones to measure accomplishment."

\section{SITE REQUIREMENT SOURCE: DOE4700.1 Attachment II-4.2.d.[6]}

"A discussion of quality assurance as it relates to the project, containing the status of development of the quality assurance plan for the project, should be included." 


\section{REQUIREMENTS IDENTIFICATION DOCUMENT \\ HIGH LEVEL WASTE STORAGE TANK FARMS \\ Research and Development and Experimental Activities \\ Revision 0}

SITE REQUIREMENT SOURCE: DOE4700.1 Attachment II-4.2.d.[7]

"A description of the atructure and links between all quality control and/or quali y assurance elements, identification of reeponsible individuals, and a deacription of the interaction and coordination among various quality control and quality aseurance functions should be provided."

\section{SITE REQUIREMENT SOURCE: DOEA700.1 Attachment II-4.2.c.[1]}

"Work Breakdown Structure. This section should briefly discuss the role of the work breakdown structure in the management of the project."

\section{SITE REQUTREMENT SOURCE: DOEA700.1 Attachment II-4.2.e.[2]}

"Provide the project summary work breakdown structure, dictionary, and element definition to level 3."

SITE REQUIREMENT SOURCE: DOEA700.1 Attachment II-4.2.f.

"Schedule. This section should expand upon the project schedule attachment to the project i plan, show at level 3 of the project summary work breakdown structure the integrated schedules of all project effort including related research and operations, and disposition."

\section{SITE REQUIREMENT SOURCE: DOEA700.1 Attachment II-4.2.f.(1)}

"These schedules should use standard DOE symbols and contain the following: Key project activities, by applicable phases of the acquisition cycle"

SITE REQUIREMENT SOURCE: DOEA700.1 Attachment II-4.2.f.(2)

"These schedules should use standard DOE symbols and contain the following: Key aspects of the project described in the work plan section"

SITE REQUIREMENT SOURCE: DOEA700.1 Attachment II-4.2.f.(3)

"These schedules should use standard DOE symbols and contain the following: Identification of all required Acquisition Executive key decisions and equivalent program Secretarial Officer decision points"

\section{SITE REQUIREMENT SOURCE: DOEA700.1 Attachment II-4.2.f.(4)}

"These schedules should use standard DOE symbols and contain the following: Significant milestones (particularly those on the critical path) by which progress of the project can be measured, including required environmental documentation"

\section{SITE REQUIREMENT SOURCE: DOEA700.1 Attachment II-4.2.f.(5)}

"These schedules should use standard DOE symbols and contain the following: Milestones for major approval/concurrence/coordination requirements from other Federal or State agencies or officials." 

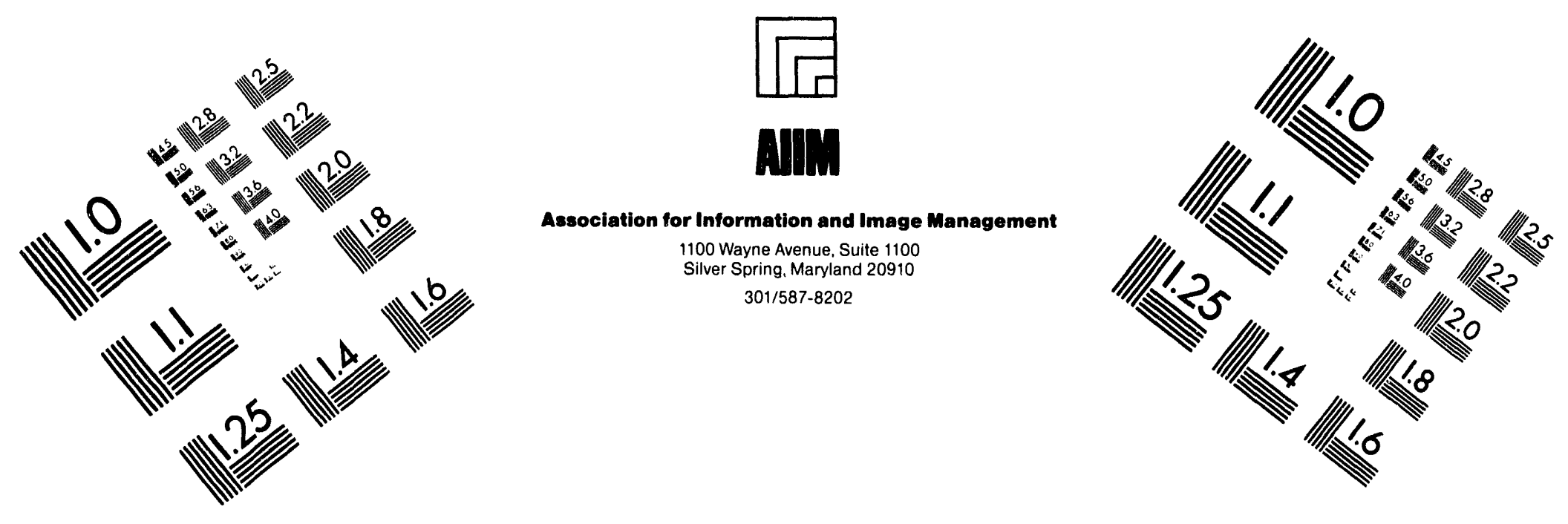

\section{Centimeter}

$\begin{array}{llllllllllllllll}1 & 2 & 3 & 4 & 5 & 6 & 7 & 8 & 9 & 10 & 11 & 12 & 13 & 14 & 15 & \mathrm{~mm}\end{array}$

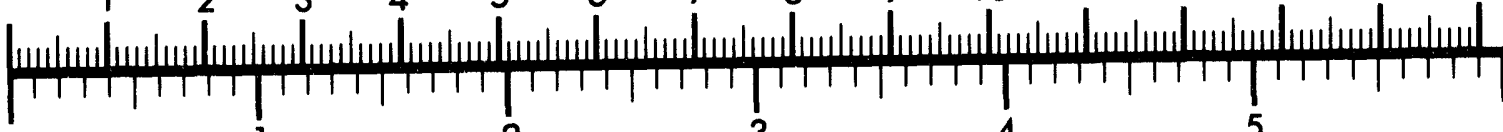
Inches

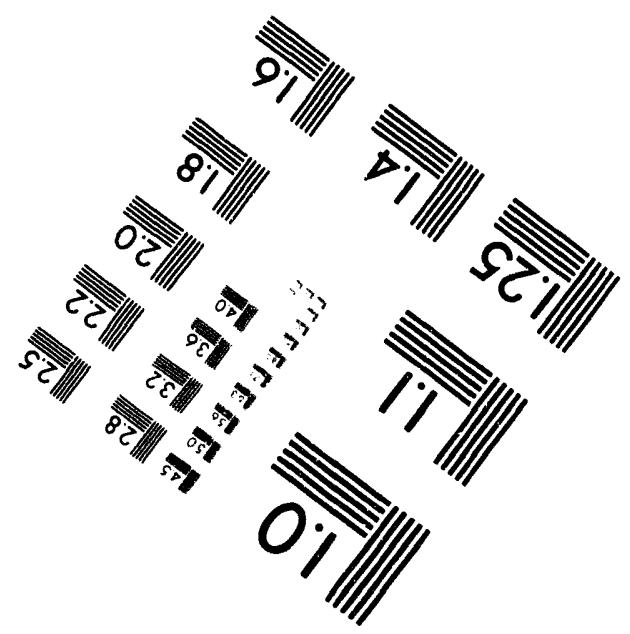

MANUFACTURED TO AIIM STANDARDS

BY APPLIED IMAGE, INC.

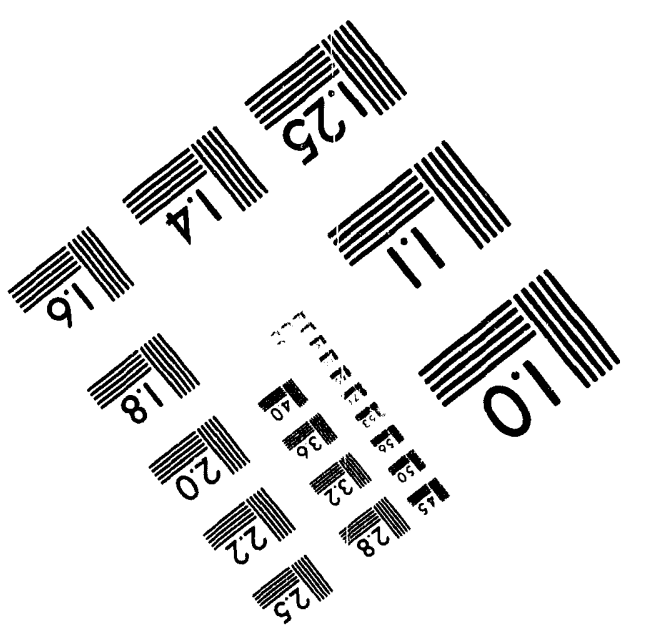



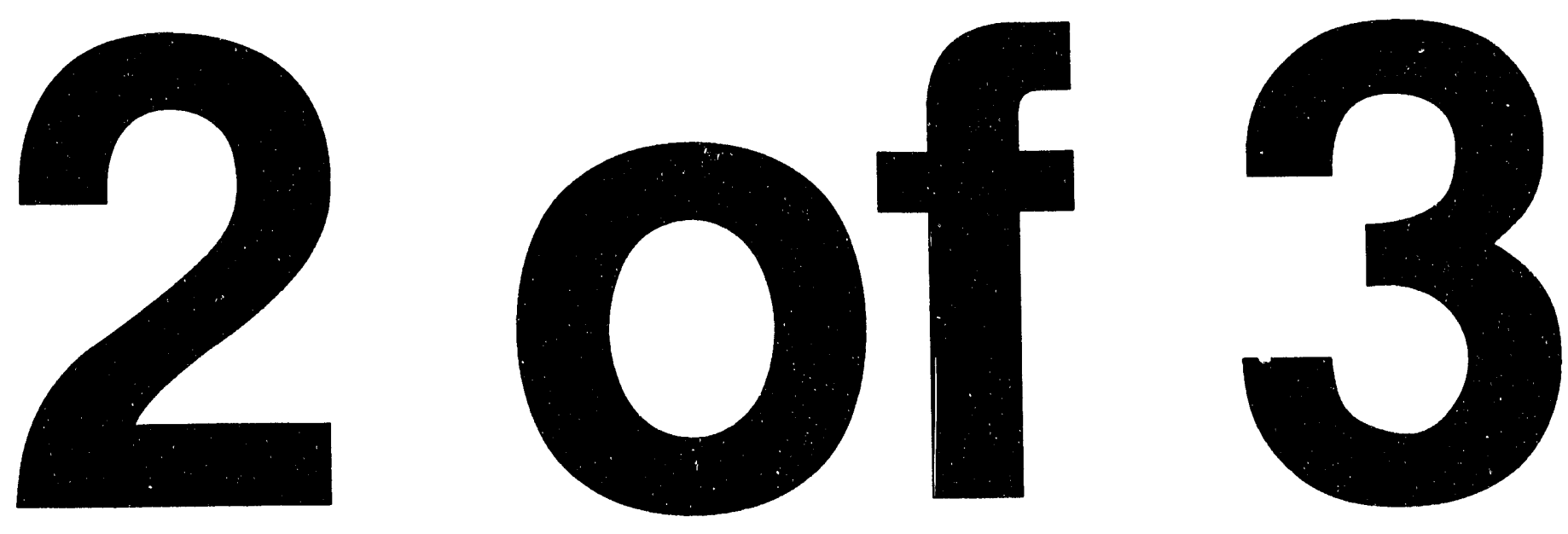


\section{REQUIREMENTS IDENTIFICATION DOCUMENT \\ HIGH LEVEL WASTE STORAGE TANK FARMS \\ Research and Development and Experimental Activities}

Revision 0

\section{SITE REQUIREMENT SOURCE: DOEA700.1 Attachment II-4.2.g.[1]}

"Depict the proper sequencing of all project elements, reflecting the work plan and schedule for the project. The logic diagram shall portray the critical path of activities/events for the project. It shall set forth all major activities, milestones and activity interface relationships and cover related research and development, remaining planning elements, criteria development, land acquisition, utility acquisition and appropriate National Environmental Policy Act documentation."

\section{SITE REQUIREMENT SOURCE: DOEA700.1 Attachment II-4.2.h.}

"Expand upon the technical objectives found in the project plan, and state in measurable, quantitative terms, the performance criteria for major subsystems..."

\section{SITE REQUIREMENT SOURCE: DOEA700.1 Attachment II-4.2.i.}

"Provide cost and manpower estimates for each project summary work breakdown structure level two and three element for the duration of the effort by fiscal year to the degree feasible, using the cost objectives stated in the project plan"

\section{SITE REQUIREMENT SOURCE: DOEA700.1 Attachment II-4.2.k.[1]}

"This section describes the integrated systems that shall be used to manage the cost, schedule, and technical performance of the project. This section shall also address funds management and control."

\section{SITE REQUTREMENT SOURCE: DOE4700.1 Attachment II-4.2.k.[2]}

"Items which should be addressed include the project management philosophy toward project control goals, and objectives and integration of the systems."

\section{SITE REQUIREMENT SOURCE: DOEA700.1 Attachment II-4.2.k.[3]}

"Each system shall be discussed with respect to required documentation, level of control, relationship to other systems' documentation and change control procedures to be utilized."

\section{SITE REQUIREMENT SOURCE: DOE4700.1 Attachment II-4.2.1.(1)}

"This section briefly summarizes all pertinent project documentation, including the document number and dates of original issuance and latest revision."

\section{SITE REQUIREMENT SOURCE: DOEA700.1 Attachment II-4.2.I.(3)}

"Provides a description and an indication of the frequency of project reviews that shall be used to keep Departmental management apprised of project progress and problems from contractor reviews to project management through reviews for DOE Headquarters management."

\section{SITE REQUIREMENT SOURCE: DOE4700.1 Attachment II-4.2.m.}

"Where systems engineering is an integral part of project execution, this section should 


\section{REQUIREMENTS IDENTIFICATION DOCUMENT HIGH LEVEL WASTE STORAGE TANK FARMS \\ Research and Development and Experimental Activities

\author{
Revision 0
}

describe the extent to which systems engineering shall be used, how the process should be managed, and who should be responsible for various aspects of management."

\section{SITE REQUIREMENT SOURCE: DOE4700.1 Attachment II-4.2.n.[2]}

"The configuration management plan should highlight the establishment and operation of a Configuration Control Board (CCB), and the identification, recording, and reporting of product interface data."

\section{SITE REQUIREMENT SOURCE: DOE4700.1 Attachment II-4.2.0.}

"This section shall outline the conditions for use and the responsibility for approval of contingency funds during execution of the project."

\section{SITE REQUIREMENT SOURCE: DOE4700.1 Attachment II-4.2.p.(1)}

"A section which contains the quality assurance program elements for an activity, group of activities, or a project and describes how conformance with such requirements is to be assured for such structures, systems, components and their operation commensurate with: the system complexity, duration and importance to satisfactory performance"

\section{SITE REQUIREMENT SOURCE: DOE4700.1 Attachment II-4.2.p.(2)}

"A section which contains the quality assurance program elements for an activity, group of activities, or a project and describes how conformance with such requirements is to be assured for such structures, systems, components and their operation commensurate with: the potential impact on environment, safety and health"

\section{SITE REQUIREMENT SOURCE: DOE4700.1 Attachment II-4.2.p.(3)}

"A section which contains the quality assurance program elements for an activity, group of activities, or a project and describes how conformance with such requirements is to be assured for such structures, systems, components and their operation commensurate with: requirements for reliability and a continuity of operations"

\section{SITE REQUIREMENT SOURCE: DOEA700.1 Attachment II-4.2.p.(4)}

"A section which contains the quality assurance program elements for an activity, group of activities, or a project and describes how conformance with such requirements is to be assured for such structures, systems, components and their operation commensurate with: reporting of unusual occurrences and remedial actions."

SITE REQUIREMENT SOURCE: DOEA700.1 Attachment II-4.2.q.

"This section defines specific actions being taken on the project to assure availability of reliable utility service for both project activities and operation."

\section{SITE REQUIREMENT SOURCE: DOE4700.1 Attachment II-4.2.s. [1]}

"The project management plan shall contain three annexes: Annex I - Advance Acquisition or Assistance Plan, Annex II - Test and Evaluation Plan, Annex III - Environmental, Safety, and 


\section{REQUIREMENTS IDENTIFICATION DOCUMENT \\ HIGH LEVEL WASTE STORAGE TANK FARMS \\ Research and Development and Experimental Activities \\ Revision 0}

Health Protection Implementation Plan."

\section{SITE REQUIREMENT SOURCE: DOEA700.1 Attachment II-4.2.s.(3)[2]}

"These actions include environment, safety and health policy; organization; training; preparation of safety analyses, National Environmental Policy Act documentation, and environmental permits; reviews and audits; reporting of unusual occurrences and remedial actions; and related management implementing procedures to protect the health and safety of employees and the public, and to minimize risks from hazards to life and property."

\section{SITE REQUIREMENT SOURCE: DOEA700.1 Attachment II-4.2.t.(2)}

"This section shall begin on a separate page. The signature page for the project management plan shall include the following: A paragraph that contains a brief statement of the work that is approved..."

\section{SITE REQUIREMENT SOURCE: DOE4700.1 Attachment II-4.2.u.(1)}

"Timely review and concurrence of project management plans are essential. The specific sequential steps in the review and approval of project management plans are as follows: The project manager notifies the program manager and the field office that preparation is beginning on the draft plan or update."

\section{SITE REQUIREMENT SOURCE: DOE4700.1 Attachment II-4.2.u.(2)}

"Timely review and concurrence of project management plans are essential. The specific sequential steps in the review and approval of project management plans are as follows: The project manager submits for review and comment one copy each to the program manager, the Head of the Field Element, and other offices deemed appropriate."

\section{SITE REQUIREMENT SOURCE: DOEA700.1 Attachment II-4.2.u.(4)}

"Timely review and concurrence of project management plans are essential. The specific sequential steps in the review and approval of project management plans are as follows: The project manager prepares the approval version in accordance with comments on the draft plan.

\section{SITE REQUIREMENT SOURCE: DOE4700.1 Attachmént II-4.2.u.(5)}

"Timely review and concurrence of project management plans are essential. The specific sequential steps in the review and approval of project management plans are as follows: The project manager sends one copy of the approval version to the program manager for concurrence."

\section{SITE REQUIREMENT SOURCE: DOEA700.1 Attachment II-4.2.u.(7)}

"Timely review and concurrence of project management plans are essential. The specific sequential steps in the review and approval of project management plans are as follows: If critical deficiencies exist, the project manager ensures that the project management plan is corrected to eliminate deficiencies and obtains program manager concurrence." 


\section{REQUIREMENTS IDENTIFICATION DOCUMENT \\ HIGH LEVEL WASTE STORAGE TANK FARMS \\ Research and Develcpment and Experimental Activities \\ Revision 0}

SITE REQUIREMENT SOURCE: DOE4700.1 Chapter II.A.2.d. [2]

"The PMP is developed by the project manager and approved by the Head of the Field Element."

Other Projects

Projects other than major system acquisitions or major projects need careful planning. The principal responsibility for initiation of other projects lies with the Head of Field Element. He or she shall develop and implement procedures for project managers to follow. As the size of projects diminishes, there is less likelihood of a formal appointment of a project manager and establishment of a project charter. This does not mean that there will not be responsible people, but simply, that the responsibility shall be understood rather than officially delegated in writing. This expedient can create problems, but its reality must be recognized.

SITE REQUIREMENT SOURCE: DOE4700.1 Attachment II-5.1.b.(4)

"These requirements include: Identification of key personnel"

SITE REQUIREMENT SOURCE: DOE4700.1 Attachment II-5.2.[1]

"A project management plan is necessary, but it does not have to be elaborate."

SITE REQUIREMENT SOURCE: DOE4700.1. Attachment II-5.2.[3]

"Even if the project is part of a larger one that has its own overall PMP, it is still necessary for managers to have a plan from which to work."

SITE REQUIREMENT SOURCE: DOE4700.1 Attachment II-5.2.a.[2]

"It lists the deliverable end products in such a way that when they are produced they can be easily identified and compared with the plan."

SITE REQUIREMENT SOURCE: DOE4700.1 Attachment II-5.2.b.[1]

"The essentials of a PMP are as follows: A list of tangible and discrete milestones, identified in such a way that there can be no ambiguity about whether a milestone has been achieved."

SITE REQUIREMENT SOURCE: DOE4700.1 Attachment II-5.2.b.[2]

"In general, the number of milestones shall correspond to reasonable dollar portions of the project budget in order to provide adequate monitoring."

SITE REQUIREMENT SOURCE: DOE4700.1 Attachment II-5.2.c.

"The essentials of a PMP are as follows: A Work Breakdown Structure that is detailed enough to provide meaningful identification of all tasks, plus all higher-level work groupings." 


\section{REQUIREMENTS IDENTIFICATION DOCUMENT \\ HIGH LEVEL WASTE STORAGE TANK FARMS \\ Research and Development and Experimental Activities \\ Revision 0}

\section{SITE REQUIREMENT SOURCE: DOE4700.1 Attachment II-5.2.d.}

"The essentials of a PMP are as follows: From the milestone list and the WBS, an activity network that shows the sequence of the elements of the project and how they are related..."

SITE REQUIREMENT SOURCE: DOEA700.1 Attachment II-5.2.e.

"The essentials of a PMP are as follows: Separate budgets and schedules for all the elements of the project that some individual is responsible for."

\section{SITE REQUIREMENT SOURCE: DOEA700.1 Attachment II-5.2.g.}

"The essentials of a PMP are as follows: An indication of the reporting and review process-what reports are needed, who reviews the project, when, and for what purpose."

SITE REQUIREMENT SOURCE: DOEA700.1 Attachment II-5.2.h.

"The essentials of a PMP are as follows: $\mathrm{A}$ list of key project personnel and their assignments in relation to the WBS."

SITE REQUIREMENT SOURCE: DOEA700.1 Attachment II-5.3.a.

"Each project, no matter how small, shall have a two- or three-level WBS."

SITE REQUIREMENT SOURCE: DOEA700.1 Attachment II-5.3.b.[1]

"Each element of the project has its own set of milestones."

SITE REQUIREMENT SOURCE: DOE4700.1 Attachment II-5.3.b.[2]

"The PMP, therefore needs a master milestone schedule."

SITE REQUIREMENT SOURCE: DOE4700.1 Attachment II-5.3.c.

"The project manager should be able to estimate the rate of expenditure as a function of time and plot it on a graph.

SITE REQUIREMENT SOURCE: DOE4700.1 Attachment II-5.3.c.(2)[1]

"The project budget shall consist of a set of plots of expenditures versus time, one for each project element and one for the total project."

SITE REQUIREMENT SOURCE: DOE4700.1 Attachment II-5.3.e. [1]

"The PMP shall include a reporting and review plan."

SITE REQUIREMENT SOURCE: DOE4700.1 Attachment II-5.3.e.(1)[1]

"Project Manager Review. The project manager shall be sufficiently close to the project so that the status is known all the time." 


\section{REQUIREMENTS IDENTIFICATION DOCUMENT \\ HUGH LEVEL WASTE STORAGE TANK FARMS \\ Research and Development and Experimental Activities \\ Revision 0}

SITE REQUIREMENT SOURCE: DOEA700.1 Attachment II-5.3.e.(2)[2]

"Find out when these reviews are scheduled and show them in the PMP."

SITE REQUIREMENT SOURCE: DOE4700.1 Attachment II-5.3.e.(3)[1]

"There must be some plan for an orderly review process."

SITE REQUIREMENT SOURCE: DOFA700.1 Attachment II-5.3.e.(3)[3]

"Be sure to allow time in the schedule for preparation of such reviews, as well as money for travel or other expenses of preparing a presentation."

SITE REQUIREMENT SOURCE: DOE4700.1 Attachment II-5.4.[1]

"When significant changes occur, the PMP should be revised and all concerned parties shall be notified."

SITE REQUIREMENT SOURCE: DOE4700.1 Attachment II-5.4.[2]

"Changes should not be made without previous evaluation of all repercussions."

SITE REQUIREMENT SOURCE: DOE4700.1 Attachment II-5.4.e.(2)

"When any change is made, the project manager shall do the following: Evaluate all the consequences of the change and make sure that all affected parts of the project (including budget and schedule) reflect the change"

\section{SITE REQUIREMENT SOURCE: DOEA700.1 Attachment II-5.4.e.(3)}

"When any change is made, the project manager shall do the following: Ensure that program manager is requested to change the project plan if there is a revision to the project baseline."

\section{FACILITIES AND EQUIPMENT}

The Functional Area of Maintenance contains the programmatic elements necessary to ensure that $R \& D / E A$ efforts conducted at existing, newly built or modified facilities; with existing or to be purchased equipment, tools, instrumentation, measuring and test equipment; and with other special purpose resources are identified, inventoried, controlled, and accounted for to ensure their availability and quality throughout the conduct of the effort. In addition, Maintenance standard procedures and practices ensures that equipment and materials are properly handled, controlled and periodically reviewed with respect to storage and safety, and to future need.

The Functional Area of Engineering Design contains the programmatic elements necessary to ensure that facilities used for a variety of R\&D/EA efforts will be designed and built with a spectrum of required services, support activities, and protective measures; this includes consideration for electrical power supplies; process and cooling water; HVAC; vaults; explosion, radiation and chemical hazard protection; access and exit for normal and emergency conditions; and seismic and flooding protection. The ES\&H Functional Area of Engineering Design, in conjunction with Nuclear Safety, ensures that facilities and equipment will not be 


\section{REQUIREMENTS IDENTIFICATION DOCUMENT \\ HIGH LEVEL WASTE STORAGE TANK FARMS \\ Research and Development and Experimental Activities}

Revision 0

used for any condition that would place them outside their design safety envelope.

The Functional Area of Operations contains the programmatic elements necessary to ensure good housekeeping practices are developed and implemented. Temporary operating conditions such as rope-offs, power interruption, and evacuations are reviewed and pre-announced to affected personnel. Standard operations procedures and practices ensure that ecuipment will be maintained in a safe and clean condition.

In addition, standard operating procedures for equipment and system alignments ensures that configuration controls are in place to maintain facilities and equipment in their safe condition and operation. Proposed modifications will be analyzed with respect to their individual safety envelope and with respect to their impact on the overall safety envelope of the existing equipment or facility, in accordance with the requirements of the Nuclear Safety Functional Area.

\section{INVENTORY CONTROL AND ACCOUNTABILITY}

R\&D/EA efforts at Tank Farms Facilities may involve the use of radioactive, toxic, and other hazardous materials. The Functional Area of Safeguards and Security contains the programmatic elements to ensure strict inventory and control requirements are maintained, including storage, shipment, and disposal of radioactive materials. Drugs and alcohol that may be used will be controlled through the requirements as delineated in the functional Area of Occupational Safety and Health. Consumable goods, precious minerals and metals, tools, and other resources and equipment that may be required in R\&D/EA activities are controlled in accordance with the requirements of the Maintenance Functional Area.

\section{CATEGORIZATION OF EFFORT}

$R \& D / E A$ programs and activities primarily include science and technology based efforts and project efforts, to a lesser degree they involve operation and support activities. R\&D/EA efforts that may be proposed for Tank Farms Facilities need to be categorized in accordance with applicable DOE Orders. R\&D efforts, in general, involve major system acquisitions (MSAs) with a value in excess of $\$ 100$ million over the life of the system or project, or major projects (MPs) with a value from $\$ 50$ to $\$ 100$ million. Other projects include line items and experimental activities with a total cost of less than $\$ 50$ million. In general, R\&D and EA programs/projects are categorized as follows:

- Major System Acquisitions (MSA)

A. National urgency, importance, size or complexity

B. Dollar value--normally those system or projects which have a total project cost in excess of $\$ 100$ million.

- Major Projects (MP)
A. Total project cost of the project from $\$ 50$ to $\$ 100$ million
B. Importance of project to program objectives.
C. Size and complexity of the project. 


\section{REQUIREMENTS IDENTIFICATION DOCUMENT \\ HIGH LEVEL WASTE STORAGE TANK FARMS \\ Research and Development and Experimental Activities \\ Revision 0}

D. Degree of DOE control required.

E. Visibility of the project.

F. Potential severity of environmental impact.

G. Recommendations by Program secretarial Officers.

- Other Projects (Other)

A. Total project cost of the project below $\$ 50$ million, including line items, and general plant projects items.

B. Line items.

C. General plant projects items.

Note: DOE 5000.4A establishes '... the Department's policy and guidelines regarding Laboratory Directed Research and Development (LDRD) at its multiprogram laboratories." With consideration of the strict funding and time limitations imposed on LDRD projects, these projects will be considered as "Other."

15.4.1 Program/Project Designation

The acquisition process is of such importance to the project evolution of a major system acquisition or major project that it is necessary to generate a basic acquisition strategy, then continuously plan to ensure that the strategy is properly implemented. Similar planning shall be done for other projects, except at a less formal level. Although most of the acquisition process is the responsibility of the cognizant contracting officer and the contract specialist, the project manager is responsible for two aspects of the acquisition process. The first is acquisition strategy, which shall be developed in harmony with the program office and the local acquisition and assistance office. The second is acquisition planning, which is conversion of the acquisition strategy to a viable, detailed plan for implementation. In both cases, the project manager can receive advice, assistance, and recommendations from a business strategy group.

\section{SITE REQUIREMENT SOURCE: DOEA700.1 Chapter,I.D.3.b.}

"Projects that fulfill the prescribed MSA or MP criteria will be so designated by the Acquisition Rxecutive using the following procedures:

Comments and unresolved designations which cannot be resolved at the program management levels will be fowarded to the Acquisition Executive for resolution. Appropriate notification of changes or additional designations is made to OMB and its Office of Federal Procurement Policy. Subsequently, a change to DOE 4240.1K, DESIGNATION OF MAJOR SYSTEM ACQUISITION AND MAJOR PROJECTS (or its successor) is issued. "

\section{Acquisition Process}

The project plan provides a summary description of a project's acquisition strategy, emphasizing overall goals and objectives. An advance acquisition or assistance plan is a component of the project management plan which describes how that strategy is to be 


\section{REQUIREMENTS IDENTIFICATION DOCUMENT \\ HIGH LEVEL WASTE STORAGE TANK FARMS \\ Research and Development and Experimental Activities \\ Revision 0}

contractually carried out. The plan serves as a transition and link between the general acquisition strategy statement included in the project plan and the detailed, transactional level business planning which is performed for each project contractual action in the project life cycle. The elements commonly included in an advance acquisition or assistance plan provide a useful checklist of factors which shall be considered and addressed in the contractual planning of any large project. These factors include those which OMB Circular A-109, "Major System Acquisitions," states shall be considered when tailoring an acquisition strategy to fit the circumstances of any large project. The details of an AAAP are included in Attachment II-7 of DOE Order 4700.1. One of the most important of these items in project planning is consideration of the acquisition process, including employment of proper lead times for contract actions.

\section{SITE REQUIREMENT SOURCE: DOEA700.1 Chapter I.D.4.a.[1]}

"Each major system acquisition or major project is directed through the acquisition process by the project manager who has a charter which provides sufficient authority and resources to accomplish the stated project objectives and goals."

\section{Project Approvals And Execution}

Project planning for Major System Acquisitions or Major Projects requires three key documents during the project approval and execution processes: the Justification of Mission Need, the Project Plan, and the project management plan. During the development of these documents, particular attention must be paid to the following requirements:

\section{SITE REQUIREMENT SOURCE: DOE4700.1 Chapter I.D.5.}

"Three documents are required during the project approval and execution processes--the justification for new start, the project plan, and the project management plan."

\section{SITE REQUIREMENT SOURCE: DOEA700.1 Chapter I.D.5.a.[4]}

"A realistic work breakdown structure is developed for each project as a framework for planning and assignment of responsibilities, contracting and reporting progress."

\section{SITE REQUIREMENT SOURCE: DOE4700.1 Chapter'I.D.5.c.[4]}

"At key decisions 3 and 4, favorable decisions may not be made unless the system's project acquisition and operating costs are available."

SITE REQUIREMENT SOURCE: DOEA700.1 Chapter I.D.5.e.[2]

"Alternative solutions to the mission need shall be obtained competitively unless the Acquisition Executive has approved pursuing a single concept."

\section{SITE REQUIREMENT SOURCE: DOE4700.1 Chapter I.D.5.e.[3]}

"Even when pursuing a single concept, competition shall be employed in development of the concept." 


\section{REQUIREMENTS IDENTIFICATION DOCUMENT \\ HIGH LEVEL WASTE STORAGE TANK FARMS \\ Research and Development and Experimental Activities}

Revision 0

SITE REQUIREMENT SOURCE: DOE4700.1 Chapter I.D.5.e.[5]

"At a minimum, solicitations shall outline the need in mission terms; identify schedule objectives and constraints; and present project system cost objectives."

\section{Other Projects}

Other projects are not subject to the policy of OMB Circular A-109. However, other projects of significant value should adhere to the same management conditions and practices as larger projects to the extent practicable. The program Secretarial Officer, program manager, or the Head of the Field Element is responsible for proper application of the Project Management System: This includes choosing management practices commensurate with the size, scope and complexity of the project.

\section{SITE REQUIREMENT SOURCE: DOE4700.1 Chapter I.E.2.b.(1)}

"In a manner similar to key decisions, there should be an affirmative determination to: Begin a project"

\section{SAFETY}

Personnel and public safety are the overriding criteria for all R\&D and experimental activities. The conduct of such activities in dedicated R\&D facilities such as the Tank Farms Facilities, as well as individual experiments, are controlled through significant interface with the programmatic elements of other ES\&H Functional Areas. From the early stages of planning through design, construction and into operation, the following functional area Requirement Identification Documents (RIDs) identify the programmatic elements which assure the safe and efficient conduct of R\&D/EA activities:

a. Radiation Safety is govemed by "Radiological Protection"

b. Environmental Safety is govemed by "Environmental Protection"

c. Nuclear Safety is governed by "Nuclear Safety"

d. Occupational safety is governed by "Occupational Safety \& Health"

e. Emergency Planning is governed by "Emergency Preparedness and Management"

A comprehensive health and safety program must be established and utilized for all Departmental construction projects. Section 15.1 .4 contains additional requirements for a comprehensive Environmental, Safety, and Health protection Implementation Plan that will be prepared as part of the Project management Plan. The goals of health and safety program are to protect DOE employees, contractor employees, and the general public from hazards; to protect property from damage, and to prevent delay or interruption in the Department's programs caused by accidents and fires in connection with construction activities.

\section{SITE REQUIREMENT SOURCE: DOEA700.1 Chapter V, Section A.2.1}

"Construction Health and Safety. A comprehensive health and safety program must be established and utilized for all Departmental construction projects. The goals of this program 


\section{REQUIREMENTS IDENTIFICATION DOCUMENT HIGH LEVEL WASTE STORAGE TANK FARMS Research and Development and Experimental Activities Revision 0}

are to protect DOE employees, contractor employees, and the general public from hazards; to protect property from damage, and to prevent delay or interruption in the Department's programs caused by accidents and fires in connection with construction activities. The authorities, responsibilities, and standards for construction safety are contained in DOE 5480.1A, DOE 5481.1A, and DOE 6430.1. Chapter 10. Consideration of safety requirements must begin early in the planning phase of a project to ensure that they are included in all plans, studies, schedules, and cost estimates. An example of a safety requirement which must begin early is the case in which additional real state may be required to achieve fire separations necessary to meet the improved risk criteria of DOE 5480.1A."

\section{SAFETY REVIEW COMMITTEE}

The Safety Review Committee (SRC) is an essential element in the planning and performance of any R\&D and EA program. Prior to the commencement of construction of a new R\&D test facility, modification of an existing facility or setup of an individual experiment, and prior to initiating any $R \& D / E A$ activity, the proposed configuration and performance for the program should be reviewed by a SRC. The ES\&H Functional Area of Nuclear Safety contains the programmatic elements that govern the policy, objectives, composition, requirements, authority, and responsibility of the SRC.

\section{SITE REQUIREMENT SOURCE: DOE4700.1 Chapter II.F.3.b.(2)(b)[3]}

"The independent review includes a document evaluation of the adequacy of the preventive or mitigative design features and the administrative controls provided to limit the probability of an adverse occurrence or the severity of a hazard."

\section{PROJECT PROPOSAL}

R\&D/EA programs are based on a need which may be identified by DOE Headquarters or by a DOE Field Office, by the site or facility contractor, by an individual researcher or engineer at a facility, or by other individuals or organizations including other government departments or agencies and non-government organizations. For each case, the need for the R\&D/EA program should be documented and the necessary authorization and funding be established. Generally, the need for a new or major R\&D effort is identified by a DOE Headquarters Office based on DOE policy or the established mission for the facility. Modifications or continuation of ongoing R\&D are typically identified by a DOE Headquarters Office, DOE Field Office or the site/facility contractor.

The need for specific experiments, in general, is identified by an individual investigator. The purpose of the effort and application of the results should be documented. R\&D/EA projects should be assigned to an individual or team of the contractor or an independent organization to prepare a specific proposal for the effort. The proposal should define the scope of the R\&D/EA, its objective, the expected outcome, projected material and manpower resources to conduct this effort, and a plan for waste disposal. The proposal should identify recommended facilities or locations for the R\&D/EA and project schedule. The proposal should be prepared in accordance with DOE requirements, including cost estimates, funding availability, and options. For major R\&D programs the proposal should be a formal, documented process, and plan. For individual experimental activities that fall within the overall mission of a laboratory

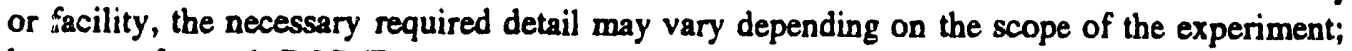
however, for each R\&D/EA program, a written proposal and test plan should be prepared and documented. In addition to the requirements presented below, section 15.1 (Program 


\section{REQUIREMENTS IDENTIFICATION DOCUMENT HIGH LEVEL WASTE STORAGE TANK FARMS Research and Development and Experimental Activities}

\section{Revision 0}

Management) of this RID, presents a compilation of programmatic planning and evaluation requirements that should be considered in developing a comprehensive Project Proposal.

\section{SITE REQUIREMENT SOURCE: DOEA700.1 Chapter I.B.2.c.}

"There is a clear hierarchical relationship between missions, programs, and projects."

\section{SITE REQUIREMENT SOURCE: DOE5000.4A 9.a.[1]}

"Each laboratory will establish a defined process, utilizing irternal peer and/or scientific management roview, with selection criteria which emphasizes scientific and technological excellence."

\section{CONCEPT AND FEASIBILITY STUDY}

Prior to proceeding with the development of a detailed design for R\&D/EA programs, the feasibility of the proposed project/activity will be evaluated (see Technical Plan requirements of Section 15.1.5.2 for Technology Evaluation guidelines). Evaluations should be performed by an individual or team that was not directly involved in the development of the proposal and may include the DOE, site/facility contractor, or other researchers/engineers. The intent of this evaluation is to access the technical risks associated with a given project and to explore alternate approaches, concepts and technology in order to minimize overall project expenditures. The performance of a Concept and Feasibility Study is intended primarily for MSAs and MPs. Studies of R\&D/EA activities that may be proposed at Tank Farms Facilities will be directed at the discretion of management as deemed necessary.

\section{State-Of-The-Art Evaluations}

Technical risk can virtually be eliminated by requiring proven technology to be available prior to project initiation. The impact of this requirement, however, may be severe in terms of cost and schedule penalties as well as unrealistic for meeting a mission need. In other words, there must often be a tradeoff between project schedule and state-of-the-art technology. An assessment has to be made of the impact of one or the other situations.

\section{SITE REQUIREMENT SOURCE: DOEA700.1 Chapter I.B.4.b.[1]}

"This state-of-the-art assessment is primarily the responsibility of the program manager, who has better visibility into the technology related to his program."

\section{SITE REQUTREMENT SOURCE: DOEA700.1 Chapter 1.B.4.b.[2]}

"The assessment should then become an integral part of the risk assess ment aspect of the justification for new start and be summarized in the alternatives and cafability section."

\section{Major Acquisitions}

OMB has issued an Executive Department policy statement entitled "Major System Acquisitions" (OMB Circular A-109). This circular establishes policy to be followed by executive branch agencies in the acquisition of major systems and provides basic policy guidance for the PMS. DOE MSAs and MPs shall conform to these requirements. 


\section{REQUIREMENTS IDENTIFICATION DOCUMENT \\ HIGH LEVEL WASTE STORAGE TANK FARMS \\ Research and Development and Experimental Activities \\ Revision 0}

OMB and DOE policy requirements include:

(1) Top level management attention to the determination of agency mission needs and goals;

(2) An integrated systematic approach for establishing mission needs, budgeting, contracting, and managing programs;

(3) Early direction of research and development efforts to satisfy mission needs and goals;

(4) Improved opportunities for innovative private sector contributions to national needs;

(5) Avoidance of premature commitments to full-scale development and production/operations; and

(6) Early communication with Congress in the acquisition process by relating MSAs to agency mission needs and goals.

(7) Early identification of projects requiring major siting decisions.

\section{STTE REQUIREMENT SOURCE: DOE4700.1 Attachment 1-3.1.a.(3)}

"When required to satisfy mission responsibilities, contributions will be made to the technology base by the conduct, support, or sponsorship of research; system design concept studies; proof of concept work; exploratory subsystem development; and tests and evaluations.

\section{SITE REQUIREMENT SOURCE: DOE4700.1 Attachment I-3.1.b.(1)[1]}

"Intended benefits to be derived from major system acquisitions shall be optimized by competitive exploration of altemative system design concepts and tradeoffs of capability, schedule, cost."

\section{SITE REQUIREMENT SOURCE: DOE4700.1 Attachment I-3.1.b.(2)[1]}

"Alternative system design concepts will be solicited from a broad base of qualified firms through the competitive procurement process. In order to achieve the most preferred system solution, emphasis will be placed on innovation and competition."

\section{SITE REQUIREMENT SOURCE: DOE4700.1 Attachment I-3.1.b.(3)[1]}

"Requests for alternative system design concept proposals will explain the mission need, schedule, cost, capability goals, and operating constraints."

\section{SITE REQUIREMENT SOURCE: DOEA700.1 Attachment I-3.1.b.(5)}

"Research and development efforts shall emphasize early competitive exploration of alternatives as relatively inexpensive insurance against the premature or preordained choice of a system that may prove to be either more costly or less effective." 


\title{
REQUIREMENTS IDENTIFICATION DOCUMENT \\ HIGH LEVEL WASTE STORAGE TANK FARMS \\ Research and Development and Experimental Activities \\ Revision 0
}

\author{
SITE REQUIREMENT SOURCE: DOEA700.1 Attachment I-3.1.b.(8)[1]
}

"Development of subsystems that are intended to be included in a major system acquisition shall be restricted to less than fully designed hardw/are (full-scale development) until the subsystem is identified as part of a system candidate for full-scale development."

\section{SITE REQUIREMENT SOURCE: DOE4700.1 Attachment I-3.1.c.(2)[1]}

"Development of a single system design concept that has not been competitively selected should be considered only if justified by urgency of need or by the physical and financial impracticability of demonstrating alternatives."

\section{SITE REQUIREMENT SOURCE: DOE4700.1 Attachment 1-3.1.c.(3)[1]}

"Major system acquisitions will be structured and resources planned to demonstrate and evaluate competing alternative system design concepts that have been selected."

\section{PLANNING AND ESTIMATING}

As presented in Section 15.1, the project manager's planning activities include developing a plan for management and control of the project that ensures a baseline is established and followed to the maximum extent possible.

Prior to the detailed design, the resources, schedule, test plan, and programmatic controls will be established..The Project management planning activities include development of the following:
a. Project Organization
b. Technical Plan
c. Risk Assessment
d. Acquisition Strategy
e. Project Schedule
f. Project Resource Plan
g. Controlled Items Baseline
h. Project Management Plan

A critical part of the management effort is to establish Cost Estimates and a Cost Baseline for newly conceived projects. Previously, DOE used Cost and Schedule Control Systems Criteria (CSCSC) to evaluate management systems on selected contracts primarily for MSAs and MPs. Use of the CSCSC were normally neither required nor encouraged for all other projects. Consequently, the Department had no existing policy for application of overall, integrated project controls to the wide range of DOE projects. Replacing the CSCSC with more comprehensive guidelines and requiring application of these guidelines to all construction and environmental projects significantly expands fundamental controls across the spectrum of DOE projects.

\subsubsection{Cost Estimating}

The primary objectives of Cost Estimating are to place emphasis on the key aspects of baseline budget development, emphasize the importance of accurate estimates at-completion, and retain the separation of expense and capital monies. Additional details of Cost estimating and 


\section{REQUIREMENTS IDENTIFICATION DOCUMENT \\ HIGH LEVEL WASTE STORAGE TANK FARMS \\ Research and Development and Experimental Activities \\ Revision 0}

Contingency Planning are contained in DOE Order 4700.1 Chapter II, Part D.

SITE REQUIREMENT SOURCE: DOEN4700.5 Attachment 2, Section 2.a.3.b.1

"Prepare cost estimates using appropriate estimating methodologies that are integrated with the WBS, and the DOE cost structure as specified by the DOE, for all contract work. Ensure that all estimates are consistent with DOE 5700.2D and in accordance with FAR 15.804, "Cost and Price Data Analysis, as applicable."

SITE REQUIREMENT SOURCE: DOEN4700.5 Attachment 2, Section 2.a.3.b.2

\section{Cost Baseline}

The objectives of establishing a cost baseline are to ensure the following:

1. An account structure is established to collect costs against specific scopes of work, and to measure performance;

2. Budgets for labor, services, subcontracts, and materials are established at the proper levels and time phased in accordance with the project schedule;

3. The total project cost is accounted for within the system; and

4. That the project direct costs and indirect costs are identified and managed.

SITE REQUIREMENT SOURCE: DOEN4700.5 Attachment 2, Section 2.a.5.(b).1

"Develop a control account structure that is integrated with the WBS, and facilitates collection of expense and capital costs, by organization and cost element as appropriate. Establish and implement a process for controlling the opening and closing of control accounts for the life of the project."

SITE REQUIREMENT SOURCE: DOEN4700.5 Attachment 2, Section 2.a.5.(b).2

"Identify, in each control account, the work scope for that account. Establish a budget for the work, ensuring the budget is time phased in accordance with the schedule baseline and the availability of resources. Ensure the control account budget basis is reconcilable with the cost estimate and subsequently approved revisions."

\section{SITE REQUIREMENT SOURCE: DOEN4700.5 Attachment 2, Section 2.a.5.(b).3}

"Ensure that all work is represented in control accounts, and the sum of all control account budgets, plus contingency, and management reserve and fee, equals the TPC or contract value, as appropriate. Ensure that budget values used for planning purposes, that are not included in the approved project baseline, are identified as such."

SITE REQUIREMENT SOURCE: DOEN4700.5 Attachment 2, Section 2.a.5.(b).4

"Establish a practical and effective method of measuring performance in the control account prior to beginning work. Maintain continuity of the measurement method throughout the life of the control account. Ensure that values used for performance determinations are verifiable and 


\section{REQUIREMENTS IDENTIFICATION DOCUMENT HIGH LEVEL WASTE STORAGE TANK FARMS \\ Research and Development and Experimental Activities}

Revision 0

consistent with schedule performance."

SITE REQUIREMENT SOURCE: DOEN4700.5 Attachment 2, Section 2.a.5.(b).5

"Establish and maintain an auditable system for the development, maintenance, analysis and control of indirect budgets and costs."

SITE REQUIREMENT SOURCE: DOEN4700.5 Attachment 2, Section 2.a.5.(b).6

"When a management reserve is established, ensure that procedures are in place to control its establishment, use, and replenishment."

SITE REQUTREMENT SOURCE: DOEN47U0.5 Attachment 2, Section 2.a.a

"PROJECT CONTROL SYSTEM GUIDELINES (GUIDELINES). The Guidelines are divided into three categories: baseline development, project performance, and change management.

Baseline Development. This category includes management actions necessary to define project scope and responsibilities, establish baselines, and plan the project.

(1) Technical Baseline and Work Scope Definition.

(a) Objective. To structure the project's technical work to ensure defined objectives are achieved. Establish the framework to integrate all elements of the Guidelines.

(b) Elements.

1. Establish and maintain the approved project technical baseline (work scope typically established in the Conceptual Design Report) in a manner that ensures it is subject to formal change control.

2. Define all authorized project work in a Work Breakdown Structure (WBS) that represents the way the work will be estimated, scheduled, budgeted, performed and managed. Maintain the WBS to be consistent with project needs throughout the life of the project, ensuring changes to the WBS are made within a formal change control process.

(2) Roles and Responsibilities.

(a) Objective. To identify all the project's participants, their responsibilities, and the role each performs on the project.

(b) Elements.

1. Clearly identify, utilizing an Organizational Breakdown Structure (OBS) approach, to the control account level, each manager responsible for all project work. In addition, identify their functional and technical scope responsibilities, their limits of authority, and interface points with other project participants.

2. Identify the persons with the authority and responsibility for controlling indirect costs.

3. Perform control account management at the level consistent with management 


\section{REQUIREMENTS IDENTIFICATION DOCUMENT HIGH LEVEL WASTE STORAGE TANK FARMS Research and Development and Experimental Activities}

Revision 0

responsibilities, organization structure and the contractor's commonly accepted practices.

4. Ensure that each control account is assigned to a person who has the authority and responsibility to control the resources and work activities within the written technical, schedule, and cost baselines.

5. Ensure that the control account and the schedule status are recorded on a timely basis to maintain current period, cumulative-to-date and at-completion records.

6. As early as practical throughout the performance of the project, ensure that each control account is assigned to a specific project participant manager or subcontractor manager who will be' responsible for the planning and control of the work scope comprising that account.

\section{Project Planning}

In addition to the detailed planning elements which are presented in Section 15.1, project planning documentation is required to establish approved project scope and technical performance requirements, schedules, resource plans, levels of responsibility and authority, organizational interfaces, implementation plans, and accountability. This documentation is needed to assure the execution of the project within the approved technical, cost, and schedule baselines. Documents required by the Project Management System (PMS) are presented in this section, and in Figure II-1 of DOE Order 4700.1. Detailed outlines and approvals for project planning documentation for Major System Acquisitions (MSA) and major projects are included in Attachments II-1 through II-6 of DOE Order 4700.1. Planning documentation of other projects should be similar in coverage and quality, although reduced in quantity to reflect the magnitude of the project and field organization procedures.

\section{SITE REQUIREMENT SOURCE: DOEA700.1 Chapter II.A.2.a.[3]}

"Other projects are justified and approved on the basis of a project data sheet."

\section{DEVELOPMENT OF DESIGN}

The development of the final design is based on the elements of the Concept and Feasibility Study, and the Planning and Estimating. The programmatic controls of the Functional Area of Engineering Design apply to the development of the design of the R\&D/EA facilities.

This element identifies the criteria for acceptability of the facility or of the experimental test configuration, specific industry consensus standards based on applicable DOE Order requirements, and applicable life and safety standards. The final design of Tank Farms Facilities, including description of the facility, operating conditions, drawings and safety evaluation are documented in the Interim Safety Basis Report.

\section{SITE REQUIREMENT SOURCE: DOEA700.1 Chapter III, Section D.2.c}

"Design Control. Design controls should be established to enable designs to be correctly translated into specifications, drawings, procedures, and instructions. The measures for accomplishing these translations and the attendant design reviews and provisions for independent assessment inputs should be addressed. Design change control, including field changes, should be subject to design control measures commensurate with those applied to the original design, and should be approved by the organization that performed the original 


\title{
REQUIREMENTS IDENTIFICATION DOCUMENT HIGH LEVEL WASTE STORAGE TANK FARMS Research and Development and Experimental Activities
}

\author{
Revision 0
}

design."

$\underline{15.10 .1}$

Design Criteria

Development of design criteria for a facility begins at the time the need for a project is identified and is based on the functional parameters that the facility must meet. Criteria are further developed, validated, and expanded during the conceptual design phase. Criteria which are complete and specifically related to the facility requirements allows for orderly development of the design. Completeness of the design criteria is emphasized. $\cdots+1$

However, care shall be taken to avoid citing superfluous codes and standards; the primary purpose of design criteria is to narrow the criteria to only those applicable to a specific design effort. Prior to the selection of an A-E, the design criteria should be consolidated into a document that will provide guidance to the $A-E$.

\section{SITE REQUIREMENT SOURCE: DOE4700.1 Chapter V.A.2.i. [4]}

"Prior to the selection of an A-E, the design criteria should be consolidated into a document that will provide guidance to the A-E."

\section{Design Objectives}

As presented in DOE Order 4700.1, Design Objectives shall be:

(1) Achieving minimum construction costs consistent with programmatic, environmental, security, and safety requirements;

(2) Achieving technical adequacy;

(3) Achieving optimum economy in operation and maintenance; and

(4) Assuring that appropriate consideration is given to the expected period of use; quality construction practices; energy conservation, decontamination, decommissioning, and quality assurance requirements; and the appearance of completed facilities.

\section{SITE REQUIREMENT SOURCE: DOEA700.1 Chapter V.C.2.e.(2)(a) [1]}

"In Title I, the design criteria are defined in greater detail and drawings for the approved project concept are expanded with more detailed information, together with additional required drawings."

\section{SITE REQUIREMENT SOURCE: DOE4700.1 Chapter V.C.2.e.(2)(a) [2]}

"Also, further refined descriptive information and more detailed outline specifications are developed that will serve as the firm basis to proceed with definitive design (Title II)."

SITE REQUIREMENT SOURCE: DOE5820.2A Chapter I, Section 3.a(1)(a)

\section{"REQUIREMENTS.}

a. Design. 


\section{REQUIREMENTS IDENTIFICATION DOCUMENT \\ HIGH LEVEL WASTE STORAGE TANK FARMS \\ Research and Development and Experimental Activities}

\section{Revision 0}

(1) Requirements for New Facilities.

(a) Design objectives for new facilities will assure protection of the public and operating personnel from hazards associated with normal high-level waste operations, accident conditions, and the effects of natural phenomena. Other objectives are compliance with DOE policies regarding nuclear safety, quality assurance, fire protection, pollution control, and safeguards and security protection for high-level waste and protection of essential operations from the effects of potential accidents."

\section{FACILITY REQUIREMENT SOURCE: DOE5820.2A Chapter II, Section 3.g(2)}

"New interim storage facilities shall be sited, designed, constructed, and operated consistent with the requirements of applicable Resource Conservation and Recovery Act regulations and in a manner which satisfactorily addresses the following considerations at a minimum: (a) Proximity to ground water and areas of seismic activity of flood plains shall be identified, and potential impacts shall be evaluated.

(b) The facility shall be designed and operated to minimize the run on and run off of precipitation. The run off control system shall provide for collecting and sampling run off, which may come in contact with the waste packages, prior to releasing the water for discharge.

(c) An environmental monitoring system shall be provided to detect any release and migration of major radioactive and hazardous components. Background levels of primary radioactive and hazardous waste components shall be determined.

(d) The storage facility design shall minimize the possibility for the unauthorized entry of persons. (e) Incompatible wastes types shall be placed in separate packages and stored in segregated areas to prevent accidental ignition or chemical reaction.

(f) Waste storage facilities shall be designed and operated to minimize the exposure of personnel to radiation and chemicals.

(g) The storage facility operator shall inspect or verify routinely the condition of waste packages at the storage site for deterioration that may threaten human health or cause release of hazardous or radioactive components to the environment.

(h) The storage facility operator shall prepare plans that identify and describe how the site will be closed at the end of its active life. These plans shall address sampling, testing, and monitoring for major radioactive and hazardous waste components in soil and ground water.

(i) Sites that use underground storage tanks for the storage of transuranic waste shall comply with the requirements of the Resource Conservation and Recovery Act, as applicable."

\section{Quality Assurance In Design}

The goals of quality assurance are to assure that research, development, demonstration, and production activities as well as strategic facility complexes are designed in a controlled manner; that components, system, and processes are designed, developed, constructed, tested, operated, and maintained according to sound engineering standards, quality practices, and technical specifications; and that resulting technical data are valid and retrievable. Quality assurance begins with the formative style of design and continues through Titles I, II, and III services. It comprises both quality engineering and quality control (inspection). Quality 


\section{REQUIREMENTS IDENTIFICATION DOCUMENT HIGH LEVEL WASTE STORAGE TANK FARMS Research and Development and Experimental Activities \\ Revision 0}

assurance elements that shall be considered during the design and construction effort are listed below.

\section{SITE REQUIREMENT SOURCE: DOEA700.1 Chapter V.A.2.0.(1)(a)}

"Quality assurance during design shall include review of materials of construction and installed equipment for economics, compatibility with other components and maintainability."

\section{SITE REQUIREMENT SOURCE: DOE4700.1 Chapter V.A.2.0.(1)(b)}

"Continuous review of the design is required to ensure that the facility can be constructed as designed using the most efficient techniques available."

\section{SITE REQUIREMENT SOURCE: DOEA700.1 Chapter V.A.2.0.(1)(c)}

"Quality assurance during design shall include provisions to assess the operability of the facility after completion."

\section{D\&D Considerations}

Field office managers shall ensure that facilities are constructed and operated so that they may be decontaminated and decommissioned of in a cost-effective manner. Decontamination and decommissioning (D\&D) considerations shall include:

\section{SITE REQUIREMENT SOURCE: DOEA700.1 Chapter V.A.2.p.(1)}

"Decontamination and decommissioning (D\&D) considerations shall include: Limiting contamination of the facility, equipment and site to the minimum extent consistent with accomplishing the purpose of the facility."

\section{SITE REQUIREMENT SOURCE: DOEA700.1 Chapter V.A.2.p.(2)}

"Decontamination and decommissioning (D\&D) considerations shall include: Providing design features that ease decontamination."

\section{SITE REQUIREMENT SOURCE: DOEA700.1 Chapter V.A.2.p.(3)}

"Decontamination and decommissioning (D\&D) considerations shall include: Incorporate design features that promote reuse of the contaminated facilities. "

SITE REQUIREMENT SOURCE: DOEA700.1 Chapter V.A.2.p.(4)

"Decontamination and decommissioning (D\&D) considerations shall include: Consideration of D\&D costs as part of the life cycle cost."

SITE REQUIREMENT SOURCE: DOE4700.1 Chapter V.A.2.p.(5)

"Decontamination and decommissioning (D\&D) considerations shall include: Selection of a tentative D\&D method during facility design." 


\section{REQUIREMENTS IDENTIFICATION DOCUMENT \\ HIGH LEVEL WASTE STORAGE TANK FARMS \\ Research and Development and Experimental Activities}

Revision 0

$\underline{15.10 .5}$

$\underline{15.10 .6}$

Maintainability

Field office managers shall assure that facilities are designed and constructed so that they are easily and economically maintained (see DOE 4330.4). Maintainability considerations shall include:

\section{Compatibility With Master Plan}

Facilities shall be constructed in accordance with the approved site development and facility utilization plan (see DOE 4320.1A). In relation to this plan, the following procedures shall be accomplished during the planning, design, and construction of facilities:

\section{SITE REQUIREMENT SOURCE: DOEA700.1 Chapter V.A.2.r.}

"Facilities shall be constructed in accordance with the approved site development and facility utilization plan."

\section{SITE REQUIREMENT SOURCE: DOEA700.1 Chapter V.A.2.r.(1)(a)}

"In relation to this plan, the following procedures shall be accomplished during the planning, design and construction of facilities: Early in the planning stage the site development plan shall be utilized to determine: Building siting (location);"

\section{SITE REQUIREMENT SOURCE: DOEA700.1 Chapter V.A.2.r.(1)(b)}

"In relation to this plan, the following procedures shall be accomplished during the planning, design, and construction of facilities: Early in the planning stage the site development plan shall be utilized to determine: Orientation;"

\section{SITE REQUIREMENT SOURCE: DOEA700.1 Chapter V.A.2.r.(1)(c)}

"In relation to this plan, the following procedures shall be accomplished during the planning, design, and construction of facilities: Early in the planning stage the site development plan shall be utilized to determine: Exterior materials, if specified;"

\section{SITE REQUIREMENT SOURCE: DOEA700.1 Chapter V.A.2.r.(1)(d)}

"In relation to this plan, the following procedures shall be accomplished during the planning, design, and construction of facilities: Early in the planning stage the site development plan shall be utilized to determine: Height and general configuration and footprint;"

\section{SITE REQUIREMENT SOURCE: DOEA700.1 Chapter V.A.2.r.(1)(e)}

"In relation to this plan, the following procedures shall be accomplished during the planning, design, and construction of facilities: Early in the planning stage the site development plan shall be utilized to determine: Size;"

\section{SITE REQUIREMENT SOURCE: DOEA700.1 Chapter V.A.2.r.(1)(f)}

"In relation to this plan, the following procedures shall be accomplished during the planning, 


\section{REQUIREMENTS IDENTIFICATION DOCUMENT \\ HIGH LEVEL WASTE STORAGE TANK FARMS \\ Research and Development and Experimental Activities \\ Revision 0}

design, and construction of facilities: Early in the planning stage the site development plan shall be utilized to determine: Landscaping features."

\section{SITE REQUIREMENT SOURCE: DOEA700.1 Chapter V.A.2.r.(2) [2]}

"In relation to this plan, the following procedures shall be accomplished during the planning, design, and construction of facilities: Should conditions arise in which the site development plan cannot be followed or prudence dictates that it should not, then action must be taken either to effect a change to the site development plan so that it and the design are brought in consonance, or to obtain a waiver of the site development plan criteria must be obtained."

\section{SITE REQUIREMENT SOURCE: DOEA700.1 Chapter V.A.2.r.(3)(b)}

"In relation to this plan, the following procedures shall be accomplished during the planning, design, and construction of facilities: During the process of design and construction, coordination with the organization responsible for site planning shall be effected to assure that: The site development organization is aware of current developments."

\section{SITE REQUIREMENT SOURCE: DOE4700.1 Chapter V.A.2.r.(4)}

"In relation to this plan, the following procedures shall be accomplished during the planning, design, and construction of facilities: Upon completion of construction, the organization responsible for site planning shall be provided as-built drawings of the new facilities, if desired by the organization."

\subsubsection{ES\&H Considerations}

Environment, safety and health matters are to be comprehensively addressed and receive objective review, with all identifiable risks reduced to acceptably low levels, and management authorization of the operation is documented.

\section{FACILITY REQUIREMENT SOURCE: DOE5480.5 Section 8.f}

"Basic Requirements - Application of ES\&H codes, standards, and guides covering sitting, design, construction, modification, operation, maintenance, deactivation, decontamination, and decommissioning. Where established standards are determined to be inadequate or unavailable, suitable operating standards shall be developed, using contractor expertise as necessary, so that a defined ard agreed upon basis for conducting and assessing operations is established and used. The safety analysis or other design documentation shall identify, on a facility-specific basis, the standards applied."

\section{SCHEDULING}

Requirements for the Project Schedule are presented in detail Section 15.1.3.6 of the Project Plan. Guidance is provided which expands upon the project schedule attachment to the project plan to show at level 3, of the project summary work breakdown structure, the integrated schedules of all project activities including related research and operations, and disposition. The Project Schedule is required to use standard DOE symbols and contain the following:

(1) Key project activities, by applicable phases of the acquisition cycle; 


\title{
REQUIREMENTS IDENTIFICATION DOCUMENT HIGH LEVEL WASTE STORAGE TANK FARMS Research and Development and Experimental Activities
}

\author{
Revision 0
}

(2) Key aspects of the project described in the work plan section;

(3) Identification of all required Acquisition Executive key decisions and equivalent program Secretarial Officer decision points;

(4) Significant milestones (particularly those on the critical path) by which progress of the project can be measured, including required environmental documentation; and

(5) Milestones for major approval/concurrence/coordination requirements from other Federal or State agencies or officials.

Logic diagrams are to be used to depict the proper sequencing of all project elements, reflecting the work plan and schedule for the project. The logic diagram shall portray the critical path of activities/events for the project. It shall set forth all major activities, milestones and activity interface relationships and cover related research and development, remaining planning elements, criteria development, land acquisition, utility acquisition and appropriate National Environmental Policy Act documentation. It should also cover directly related elements charged to operating or capital equipment not related to construction accounts.

Additional requirements for Design and Construction Scheduling are as follows:

\section{STORAGE AREA ACCESS}

New construction of prototype or demonstration facilities, or set-up of individual experiments will be accomplished in accordance with the programmatic provisions of the Functional Area of Construction Management. Research and development performance and experimental parameters are assured to stay within the design safety envelope of the facility through a combination of configuration controls established in the Functional Areas of Configuration Management and Engineering Design, for newly constructed facilities as well as for facilities and experimental set-ups that are being modified. Other aspects of the facility construction which rely on additional ES\&H Functional Areas are:

a. Labelling of equipment and components; See Operations RID

b. Cleanliness control; See Maintenance Management RID

c. Material control and traceability; and See Construction \& Operations RID

d. Rigging control. See Construction RID

Each construction effort is unique due to the different and varying conditions, requirements, and problems associated with each project. In addition to the uniqueness of each effort, an individual project must comply with rather rigid procedures in relation to funding, safety, and other requirements. Construction industry and DOE experience have shown that efficiency and timeliness results when a construction program is conducted in conformance with a well-defined overall policy and detailed procedures for the construction effort undertaken. DOE Order 4700.1 provides an overview of the Departmental construction policy and necessary procedures to assure a coordinated construction management effort within the Department. This Order also provides guidelines to assist the managing field offices in developing their detailed management procedures.

\section{Construction Management}

Most projects accomplished by the Department require the construction of facilities as a part of the project. The activities normally associated with construction execution are depicted in 


\section{REQUIREMENTS IDENTIFICATION DOCUMENT \\ HIGH LEVEL WASTE STORAGE TANK FARMS \\ Research and Development and Experimental Activities \\ Revision 0}

Figure III-1 OF DOE Order 4700.1. A detailed construction management plan may be required by the Program Secretarial Officer prior to the start of the construction. This may be included as an attachment to the project management plan. Coordination with the managing field organization should be established to determine the specifics of each construction activity.

\section{SITE REQUIREMENT SOURCE: DOEA700.1 Chapter III.E.1.a.[2]}

"Coordination with the managing field organization should be established to determine the specifics of each construction activity."

\section{SITE REQUIREMENT SOURCE: DOEA700.1 Chapter V.A.2.a.(1)(a)}

"Effective management of construction necessitates establishing the following parameters and requirements: Clearly defined scope;"

SITE REQUIREMENT SOURCE: DOEA700.1 Chapter V.A.2.a.(1)(b)

"Effective management of construction necessitates establishing the following parameters and requirements: Adequate division of work into packages for management control;"

SITE REQUIREMENT SOURCE: DOEA700.1 Chapter V.A.2.a.(1)(c)

"Effective management of construction necessitates establishing the following parameters and requirements: Reliable cost estimates;"

SITE REQUIREMENT SOURCE: DOEA700.1 Chapter V.A.2.a.(1)(d)

"Effective management of construction necessitates establishing the following parameters and requirements: Realistic schedules;"

SITE REQUIREMENT SOURCE: DOEA700.1 Chapter V.A.2.a.(1)(h)

"Effective management of construction necessitates establishing the following parameters and requirements: Designated authorities and responsibilities;"

\section{SITE REQUIREMENT SOURCE: DOEA700.1 Chapter V.A.2.a.(1)(i)}

"Effective management of construction necessitates establishing the following parameters and requirements: Monitoring and reporting status of work;"

SITE REQUIREMENT SOURCE: DOE4700.1 Chapter V.A.2.a.(1)(j)

"Effective management of construction necessitates establishing the following parameters and requirements: Compaing progress and costs with schedules and estimates;"

\section{SITE REQUIREMENT SOURCE: DOE4700.1 Chapter V.A.2.a.(1)(k)}

"Effective management of construction necessitates establishing the following parameters and requirements: Identification of potential or actual problems;" 


\section{REQUIREMENTS IDENTIFICATION DOCUMENT \\ HIGH LEVEL WASTE STORAGE TANK FARMS \\ Research and Development and Experimental Activities \\ Revision 0}

SITE REQUIREMENT SOURCE: DOEA700.1 Chapter V.A.2.a.(1)(l)

"Effective management of construction necessitates establishing the following parameters and requirements: Prompt action to eliminate or resolve problems. "

\section{SITE REQUIREMENT SOURCE: DOEA700.1 Chapter V.A.2.c.(1) [1]}

"Specific project management plans shall be prepared for each major system acquisition and major project per Chapter II."

SITE REQUIREMENT SOURCE: DOEA700.1 Chapter V.A.2.c.(1) [2]

"Any other project that cannot be managed by use of the locally established general management plan described in subparagraph (2), below, shall also have a specific management plan."

SITE REQUIREMENT SOURCE: DOE4700.1 Chapter V.A.2.c.(1)(a)[1]

"The responsibility for development of this project management plan rests with the project."

SITE REQUIREMENT SOURCE: DOEA700.1 Chapter V.A.2.c.(1)(b)

"Specific management plans will require amplification and revision as the design and construction progress."

\section{SITE REQUIREMENT SOURCE: DOE4700.1 Chapter V.A.2.c.(2)}

"General project management plans shall be prepared for categories or types of projects which are to be managed similarly, encompassing the same areas that the specific management plans address."

\section{SITE REQUIREMENT SOURCE: DOEA700.1 Chapter V.A.2.c.(3) [1]}

"Projects managed by general management plans shall bave a specific document containing scope, estimate, schedule, and designated individuals assigned authorities and responsibilities."

\section{SITE REQUIREMENT SOURCE: DOEA700.1 Chapter V.A.2.d.(2) [3]}

"The responsibilities of the designated individual shall be well defined and the appropriate authority is vested in the individual to allow accomplishment of his/her responsibilities."

15.12.2 Construction Procedures

Construction management includes implementing procedures and providing guidance for project activities that occur during the execution phase of a project. The execution phase begins upon completion of detailed design and receipt of construction funds at the level responsible for project management, and continues until the completion and closeout of the construction effort. 


\section{REQUIREMENTS IDENTIFICATION DOCUMENT \\ HIGH LEVEL WASTE STORAGE TANK FARMS \\ Research and Development and Experimental Activities \\ Revision 0}

\subsubsection{Project Control}

DOE does not impose any specific Project Control System on its contractors, as the general control elements are normally inherent in individual contractor management control systems. Contractors are allowed maximum flexibility in determining how internal operations are to be conducted as long as the internal management control systems satisfy the needs of both the contractor and the Department for contract performance information.

\section{STTE REQUIREMENT SOURCE: DOEN4700.5 Section 9.b}

"The Guidelines shall be applicable to DOE contractors performing DOE project work. The Guidelines reflect the needs of sound project management while providing flexibility. Flowdown of Guidelines to individual contractors within a project, and the degree of application of each guideline element, shall consider risk, duration, cost, management utility, cost effectiveness, and contract type. Fixed-price contracts will normally be required to implement selected guideline elements; schedule status reporting, problem reporting, and change management are examples of guideline elements that may be required on fixed-price contracts."

\section{Performance Measurement}

Reporting and performance measurement systems in project management are used to effectively control project execution. Contractor compliance with work breakdown structure, cost and schedule control and performance reporting provides the necessary assurance that the Department has the basic data required for timely and meaningful management decisions.

\section{SITE REQUIREMENT SOURCE: DOEA700.1 Chapter III.F. 2.b.[2]}

"The cost, schedule, and technical report data are measured against original baselines to determine variance and assess percent completion."

\subsubsection{Project Reporting}

Comprehensive plans and reports for each project will provide proper visibility of project status during execution. Identifying the proper requirements requires a knowledge of the project objectives, baselines to be tracked, total estimated cost of the project, and the type of contract or Federal assistance involved. With this information in hand, a reasonable selection of plans and reports can be made. A further determination of how plan and report data is to be displayed shall also be made.

\section{SITE REQUIREMENT SOURCE: DOEA700.1 Chapter III.F. 3.b.}

"Once a decision is made as to which plans and reports are required for the project, this information should be transferred to a Reporting Requirements Checklist."

\section{SITE REQUIREMENT SOURCE: DOEA700.1 Chapter III.F. 3.c.[1]}

"The project manager should be aware of the information needs of other Departmental Elements and shall make arrangements for them to receive the necessary reports in the required quantity." 


\section{REQUIREMENTS IDENTIFICATION DOCUMENT HIGH LEVEL WASTE STORAGE TANK FARMS Research and Development and Experimental Activities Revision 0}

\section{SITE REQUIREMENT SOURCE: DOEA700.1 Chapter III.F. 3.c.[2]}

"Organizations designated to receive reports shall be so advised."

\section{Special Requirements}

For Multi-Participant Projects it will be necessary to summarize information from several contractual agreements into a single report for an overview of the project. A project involving construction is an example of such an occasion. In this instance, the system shall feed report information to the project manager or the integrating contractor to meet DOE reporting requirements.

\section{SITE REQUIREMENT SOURCE: DOEA700.1 Chapter III.F. 4.a.[1]}

"In this instance, the system shall feed report information to the project manager or the integrating contractor to meet DOE reporting requirements."

\section{SITE REQUIREMENT SOURCE: DOEA700.1 Chapter III.F. 4.a.[2]}

"Pagination and title page requirements shall be adjusted to reflect the single document nature of this type of submittal."

\section{SITE REQUIREMENT SOURCE: DOEA700.1 Chapter III.F. 4.b.}

"In some instances, DOE may require reporting on work that is subcontracted, in which case the prime contractor may require detailed reporting by the subcontractor."

\section{SITE REQUIREMENT SOURCE: DOEA700.1 Chapter III.F. 4.c.[1]}

"Integrated contractors who use the work package authorization system (WPAS) are required also to use URS reports."

\subsubsection{Project Management Plan}

The management plan is the key contractor input to URS: It contains the Milestone Schedule Plan and Cost Plan. The management plan describes the process for developing the products identified in the contractual agreement, and names the management control systems to be used to manage that performance. It is required as part of the proposal and after negotiations become a binding part of the contractual agreement.

\section{SITE REQUIREMENT SOURCE: DOEA700.1 Chapter III.F. 5.b.[1]}

"The management plan should reflect how the contractor(s) plans to execute the project."

\section{Cost And Schedule Control}

A comerstone of the Department's project management policy is the concept of accountability at appropriate levels for project control and management. Project managers, as accountable managers, must be directly involved in the application of overall project controls. This policy ensures that the accountable project manager is responsible for appropriate application of 


\section{REQUIREMENTS IDENTIFICATION DOCUMENT HIGH LEVEL WASTE STORAGE TANK FARMS Research and Development and Experimental Activities Revision 0}

overall project controls.

An essential element of accountability is overall project control of technical scope, cost, and schedule baselines as well as associated research and development (R\&D), transition planning and baseline changes. DOE's policy as delineated in DOE Notice 4700.5 identifies requirements for all elements of project control and expands earlier Cost and Schedule Control System Criteria to encompass overall control by placing greater emphasis on control of technical, schedule, and cost baselines and baseline changes.

\section{SITE REQUIREMENT SOURCE: DOEN4700.5 Attachment 2, Section 1.b}

"For contractors responding to a solicitation to perform project work, an element in the evaluation of proposals will be the offeror's systems for planning and controlling contract performance. The offeror will fully describe the system to be used. The system described in the proposal will be evaluated to determine whether it meets the necessary project management control Guidelines promulgated by this notice."

\section{CONDUCT OF R\&D/EA PROGRAM}

Prior to the initiation of testing in a R\&D facility or performance of an individual experiment, participating personnel are to be briefed on the test objectives and instructed (trained and tested as necessary) on the test procedures with particular emphasis on individual worker and overall safety of the test. The test abort/shutdown criteria should be reviewed, including criteria and procedures for escape or evacuation of the facility. Other aspects to be included in the performance of the test are:

a. Initial test conditions;

b. Control limits;

c. Inspection points;

d. Monitoring requirements; and

e. Test restoration.

The quality assurance controls should be established in accordance with the guidance of the Quality Assurance Functional Area. Records of all test assumptions, parameters, test performance, and results need to be documented in accordance with the general guidance for Document Control and Records Management in the management Systems Functional Area.

The Functional Areas of Construction and Operations provide additional detailed requirements for system and equipment testing. The requirements sited below are based primarily on DOE Order $\mathbf{4 7 0 0 . 1}$ and generally overview testing requirements in the facility construction or modification phase. However, the basis for these same requirements is applicable to the development and conduct of special test procedures that will be encountered in selective R\&D/EA programs that may be expected at the Tank Farms Facilities.

\section{SITE REQUIREMENT SOURCE: DOEA700.1 Chapter III, Section D.2.k [1]}

"A test program should be established to assure that all testing required to demonstrate that structures, systems, and components will perform satisfactorily in service, is identified and performed in accordance with written test procedures which incorporate the requirements and acceptance limits contained in applicable design documents. " 


\section{REQUIREMENTS IDENTIFICATION DOCUMENT HIGH LEVEL WASTE STORAGE TANK FARMS \\ Research and Development and Experimental Activities

\author{
Revision 0
}

SITE REQUIREMENT SOURCE: DOEA700.1 Chapter III, Section D.2.k [2]

"The test program should include, as appropriate, proof tests prior to installation, preoperational tests, and operational tests during facility operation of structures, systems, and components."

\section{Test And Evaluation Plan}

The test and evaluation plan should consider both component and systems testing to help ensure technical performance. The plan should relate the test and evaluation effort to the project's technical risks, operability, performance criteria, reliability, availability and maintainability. The test program should measure technical performance, to assure the project manager that the technical baseline can be met. DOE Order 4700.1 provides a suggested outline of a test and evaluation plan for MSA/MP's and also gives an illustration of a comprehensive test program for the measurement of technical performance for an integrated, complex project.

\section{SITE REQUIREMENT SOURCE: DOEA700.1 Attachment III-3.1.[2]}

"This document should be detailed to the extent necessary to show the rationale for the kind, amount, and schedules of the testing planned for the project."

\section{SITE REQUIREMENT SOURCE: DOEA700.1 Attachment III-3.1.[3]}

"It should relate the test and evaluation effort clearly to the project's technical risks, operational issues and concepts, performance criteria, reliability, availability, maintainability, and acquisition phase key decisions."

\section{SITE REQUIREMENT SOURCE: DOE4700.1 Attachment III-3.1.[4]}

"It explains the relationship of component, subsystem, integrated system development tests, and initial operational tests which when analyzed together provide confidence that the project is ready to proceed to the next phase of the acquisition process."

\section{SITE REQUIREMENT SOURCE: DOEA700.1 Attachment III-3.1.a.[1]}

"The plan addresses the testing and evaluation to be performed in each acquisition phase with the upcoming phase discussed in more detail."

SITE REQUIREMENT SOURCE: DOEA700.1 Attachment III-3.1.a.[2]

"In general, the plan should address critical tests and evaluations, and near-term and long-term plans, by acquisition phase."

\section{SITE REQUIREMENT SOURCE: DOEA700.1 Attachment III-3.1.b.[1]}

"The plan should outline the test and evaluation management responsibilities of participating organizations including independent testing and evaluation to be performed by another agency or Departmental elements." 


\section{REQUIREMENTS IDENTIFICATION DOCUMENT HIGH LEVEL WASTE STORAGE TANK FARMS \\ Research and Development and Experimental Activities Revision 0}

SITE REQUIREMENT SOURCE: DOEA700.1 Attachment III-3.1.b.[2]

"If independent testing is not going to be performed, justification shall be provided."

SITE REQUIREMENT SOURCE: DOEA700.1 Attachment III-3.1.b.[3]

"Highlight arrangements between participants for sharing test data and responsibilities for test management decisions, and discuss the adequacy of the planned test periods and schedule to provide confidence in test results."

SITE REQUIREMENT SOURCE: DOEA700.1 Attachment III-3.1.c.(1)[1]

"On a summary level milestone chart, display the integrated time sequencing of developmental tests (sometimes known as research and development tests) and evaluations for the project and the acquisition cycle key decision points."

SITE REQUIREMENT SOURCE: DOEA700.1 Attachment III-3.1.c.(1)[3]

"Relate the planned testing to the critical technical issues appropriate to each phase."

SITE REQUIREMENT SOURCE: DOEA700.1 Attachment III-3.1.c.(1)[5]

"Provide, as an attachment, a listing of the issued and planned test procedures, indicating the level two, level three, and selected high risk, lower level project summary work breakdown structure elements to which they are applicable."

SITE REQUIREMENT SOURCE: DOEA700.1 Attachment III-3.1.c.(2)[1]

"Provide, by phase of the acquisition cycle, a summary of the developmental tests and evaluations already conducted based on the best available information."

SITE REQUIREMENT SOURCE: DOEA700.1 Attachment III-3.1.c.(2)[3]

"Emphasize events and results related to required performance characteristics, critical issues, and requirements from earlier management decisions."

SITE REQUIREMENT SOURCE: DOEA700.1 Attachment III-3.1.c.(2)[4]

"Highlight technical characteristics or specification requirements that are to be demonstrated or, from related projects or test programs, systems, subsystems, or components which have failed to be demonstrated."

SITE REQUIREMENT SOURCE: DOEA700.1 Attachment III-3.1.c.(3)[1]

"Discuss remaining tests and evaluations planned for the life of the project beginning with the current phase of the acquisition cycle."

SITE REQUIREMENT SOURCE: DOEA700.1 Attachment III-3.1.c.(4)[1]

"Discuss the operational tests and evaluations to be performed in the demonstration. and the 


\section{REQUIREMENTS IDENTIFICATION DOCUMENT \\ HIGH LEVEL WASTE STORAGE TANK FARMS \\ Research and Development and Experimental Activities \\ Revision 0}

production or operation phases of the acquisition cycle intended to address operational effectiveness and identify deficiencies in the system."

STTE REQUIREMENT SOURCE: DOE4700.1 Attachment III-3.1.c.(4)[2]

"Relate the test conditions and expected results to the operational effectiveness and suitability of the systems being acquired.

SITE REQUIREMENT SOURCE: DOEA700.1 Attachment III-3.1.c.(5) [4]

"Identify planned testing facilities and whether they are Government or non-Government facilities."

SITE REQUIREMENT SOURCE: DOEA700.1 Attachment III-3.1.c.(5)[1]

"Summarize the resources required that are unique to the project."

SITE REQUIREMENT SOURCE: DOEA700.1 Attachment III-3.1.c.(5)[2]

"Identify the actual number of articles and support elements of the system required for testing in each phase."

SITE REQUIREMENT SOURCE: DOEA700.1 Attachment III-3.1.c.(5)[3]

"If subsystems are to be tested individually, identify each subsystem and the quantity required."

SITE REQUIREMENT SOURCE: DOEA700.1 Attachment III-3.2.b.

"AN INTEGRATED TEST AND EVALUATION PLAN shall consider the following:

Operational Test Plan."

SITE REQUIREMENT SOURCE: DOEA700.1 Attachment III-3.2.c.

"AN INTEGRATED TEST AND EVALUATION PLAN shall consider the following: Test Resource Requirements."

SITE REQUIREMENT SOURCE: DOEA700.1 Attachment III-3.2.d.(1)

"AN INTEGRATED TEST AND EVALUATION PLAN shall consider the following: Test Procedures: Identification of tests."

SITE REQUIREMENT SOURCE: DOEA700.1 Attachment III-3.2.d.(2)

"AN INTEGRATED TEST AND EVALUATION PLAN shall consider the following: Test Procedures: Preparation, approval, and issuance of test procedures."

SITE REQUIREMENT SOURCE: DOE4700.1 Attachment III-3.2.d.(3)

"AN INTEGRATED TEST AND EVALUATION PLAN shall consider the following: Test 


\section{REQUIREMENTS IDENTIFICATION DOCUMENT \\ HIGH LEVEL WASTE STORAGE TANK FARMS \\ Research and Development and Experimental Activities \\ Revision 0}

Procedures: Detailed scheduling."

SITE REQUIREMENT SOURCE: DOEA700.1 Attachment III-3.2.d.(4)

"AN INTEGRATED TEST AND EVALUATION PLAN shall consider the following: Test Procedures: Review and analysis of test results."

SITE REQUIREMENT SOURCE: DOEA700.1 Attachment III-3.2.e.(1)

"Acceptance tests."

SITE REQUIREMENT SOURCE: DOEA700.1 Attachment III-3.2.e.(1)(a)

"Installation check."

SITE REQUIREMENT SOURCE: DOEA700.1 Attachment III-3.2.e.(1)(b)

"Strength and tightness."

SITE REQUIREMENT SOURCE: DOEA700.1 Attachment III-3.2.e.(2)

"Alteration and repair tests."

SITE REQUIREMENT SOURCE: DOEA700.1 Attachment III-3.2.e.(3)

"Special tests."

SITE REQUTREMENT SOURCE: DOEA700.1 Attachment III-3.2.f.(1)

"Test specifications."

SITE REQUIREMENT SOURCE: DOEA700.1 Attachment III-3.2.f.(2)

"Test procedures."

SITE REQUTREMENT SOURCE: DOEA700.1 Attachment III-3.2.f.(2)(a)

"Preparation and approval."

SITE REQUIREMENT SOURCE: DOEA700.1 Attachment IIy-3.2.f.(2)(b)

"Distribution."

SITE REQUIREMENT SOURCE: DOEA700.1 Attachment III-3.2.f.(2)(c)

"Review"

SITE REQUIREMENT SOURCE: DOEA700.1 Attachment III-3.2.f.(2)(d)

"Changes" 


\section{REQUIREMENTS IDENTIFICATION DOCUMENT \\ HIGH LEVEL WASTE STORAGE TANK FARMS}

Research and Development and Experimental Activities

Revision 0

SITE REQUIREMENT SOURCE: DOEA700.1 Attachment III-3.2.h.

"AN INTEGRATED TEST AND EVALUATION PLAN shall consider the following: Teat Sequence."

SITE REQUIREMENT SOURCE: DOEA700.1 Attachment III-3.2 J.

"AN INTEGRATED TEST AND EVALUATION PLAN shall consider the following:

Test Instructions."

SITE REQUTREMENT SOURCE: DOEA700.1 Attachment III-3.2.j.(1)

"Organization."

SITE REQUIREMENT SOURCE: DOEA700.1 Attachment III-3.2.j.(2)

"Document control."

SITE REQUIREMENT SOURCE: DOEA700.1 Attachment III-3.2.j.(3)

"Status reporting."

SITE REQUIREMENT SOURCE: DOEA700.1 Attachment III-3.2.j.(4)

"Verification of testing."

SITE REQUIREMENT SOURCE: DOEA700.1 Attachment III-3.2.j.(5)

"Signoff"

SITE REQUIREMENT SOURCE: DOEA700.1 Attachment III-3.2.j.(6)

"Interruptions and incidents."

SITE REQUIREMENT SOURCE: DOEA700.1 Attachment III-3.2.j.(7)

"Testing events."

SITE REQUIREMENT SOURCE: DOEA700.1 Attachment III-3.2.j.(8)

"Monitoring records."

SITE REQUIREMENT SOURCE: DOEA700.1 Attachment III-3.3. [1]

"All operation of the plant and equipment is to be performed in accordance with Departmental procedures in applicable component technical manuals, and approved test documents." 


\section{REQUIREMENTS IDENTIFICATION DOCUMENT \\ HIGH LEVEL WASTE STORAGE TANK FARMS \\ Research and Development and Experimental Activities \\ Revision 0}

\section{SITE REQUIREMENT SOURCE: DOEA700.1 Attachment III-3.3. [2]}

"Test operating procedures supplied by the plant contractor, which are approved by DOE, may specify procedures which differ from those in applicable component technical manuals for purpoces of the teat progrim."

\section{Test Program Requirements}

A comprehensive teat program needs to seoure the sesessment of current and expected performence and identification of lochnical problems. These assessments coincide with the completion of significant design and development tasks. This provides visibility into actual versus planned technical performance, and facilitates verification of results achieved. If performance is different then plenned, change options are proposed. Revised work plans to complete major design and milestones may bo developed. The revised work plans provide the basis for forecasting cost and schedulo impacts.

\section{SITE REQUIREMENT SOURCE: DOEA700.1 Attachment III, Section 4.1.a}

"Accomplishment of a project test program requires the following actions:

(1) Identification of necessary testing;

(2) Preparation, approval, and issuance of appropriate test procedures and associated testing documents;

(3) Detailed scheduling and performance of approved test procedures; and

(4) Review and analysis of results to verify acceptability."

\section{STTE REQUIREMENT SOURCE: DOEA700.1 Attachment III-4.1.b. [2]}

"Test specifications and procedures are required for components, systems, and subsystems which are contract end items; will be contractually identified; and will be referenced in the quality assurance plan."

\section{Test Programs and Sequences}

Project test programs are normally of three types:

a. New Project Acceptance Tests. An extensive series of individual equipment, plant, and integrated project tests required to establish that the project is properly built and will perform as designed.

b. Alteration and Repair Acceptance Tests. Tests performed to establish the acceptability of project equipment or systems which have been altered or repaired.

c. Special Tests. Tests for purposes other than those listed above, such as periodic maintenance tests or troubleshooting tests. 


\title{
REQUIREMENTS IDENTIFICATION DOCUMENT HIGH LEVEL WASTE STORAGE TANK FARMS Research and Development and Experimental Activities Rerision 0
}

\author{
SITE REQUTREMENT SOURCE: DOEA700.1 Attachment III, Section 4.3.a(1)
}

"Installation Checks. This phese will include a visual inspection by system of all components and equipmeat to seoure that inatallation is in eccordance with deaign plans. Fluid systeme will be checked for proper arrangement, including locating and mounting of components, hanging and anchoring of piping, alignment and bolting of machinery locking devices, apace envelopes required for maintenance, and the secencibility of operating parts of the system.

Instrumentation and control syatems will be checked for proper inatallation, including grounding, connections, mechanical operability of components, and proper wiring, including wrapping, sorvicing, sleoving, and marking. Circuit continuity, wiring, insulation, and proper ventilation will be checked, including heat disaipation features."

\section{SITE REQUIREMENT SOURCE: DOEA700.1 Attachment III, Section 4.3.a(2)}

"Flushing and Strength and Tightnees Teste. Upon completion of the point of construction at which filling cen proceed, the fluid systems are filled and flushod. The strength and tightneas of fluid systems are proven by bydrostatic teating. Appropriate piping systems are fitted with filters that simulate the preasure drop and a teat bead prior to filling and instrumentation and control aystems are calibrated. The calibration tests are conducted prior to, and concurrently with, strength and tightness toets sequenced to moet test procedure requirements."

\section{SITE REQUTREMENT SOURCE: DOEA700.1 Attachment III, Section 4.3.a(3)}

"System Operation Testing with Minimum Parameters. Fluid systems are operated at minimum parameters for operation of appropriate equipment in order to assure, at the earliest possible date, that all components aro operable and ready for further testing. Instrumentation and control testing proceed concurrently, sequenced to meet test procedure requirements.

\section{SITE REQUTREMIENT SOURCE: DOEA700.1 Attachment III, Section 4.3.a(4)}

"System Operation with Normal Parameters. When fluid systems have been tested adequately to indicate that operating parameters can be reachod, the systems aro tested at designated higher parameters. Safety and protection devices are tested as parameters are increased. When all testing designated for this period has been satisfactorily completed, the designed parameters are reduced, the filters are removed, and the entrapped contents are examined."

\section{SITE REQUTREMENT SOURCE: DOEA700.1 Attachment III, Section 4.3.a(5)}

"Operational Testing. Upon completion of all tests in the preceding phases, the project is prepared for initial operations with designed fluids/solids. After operations testing is achieved, and as the equipment is taken to operating conditions, the equipment is tested through various levels up to 100 percent. Then the projoct is tested over various expected specified transients. The intent of this phase is to assure readiness for full operations."

\section{SITE REQUIREMENT SOURCE: DOEA700.1 Attachment III, Section 4.3.b}

\footnotetext{
"Alteration and Repair Acceptance Test Program. This test program consists of only those tests required to establish the acceptability of project equipment or systems which have been altered, repaired, opened, inspected, disassembled, and so forth, during any upgrade period. The test program is under the cognizance of a testing review board or equivalent group."
} 


\section{REQUIREMENTS IDENTIFICATION DOCUMENT FIGH LEVEL WASTE STORAGE TANK FARMS Research and Development and Experimental Activities

\author{
Revision 0
}

\section{SITE REQUTREMENT SOURCE: DOEA700.1 Attachment III, Section 4.3.c}

"Special Teat Programe. These consiat of teats performed on a project for purposes other than above, such as varying the output stream, shifting the feedatock, or varying operating parameters for integration purpoces.

\section{Tet Spectifations And Documentation}

Teat Spocifications and Teat Procedures are the basic documents of the project teat program. Specifications eatablish test requiremeats and parameters for all levels of tests performed on major components, subaystems, or systems as applicable to ensure that escential design, interface, and performance requirements are met. The specifications are developed as the system design evolves. Test Procedures specify prerequisites, special equipment, precautions, and the steps to be followed during conduct of the test. Approved written test procedures are required for the performance of all project tests. Test requirements apecify the testing to be performed and are used to prepare the detailed procedures for accomplishing testing.

\section{SITE REQUIREMENT SOURCE: DOEA700.1 Attachment III, Section 4.4.a}

"Test specifications. Specifications will costablish tost requirements and parameters for all levels of tests performed on major components, subsystems, or systems as applicable to ensure that essential design, interface, and performance requirements are met. The specifications will be developed as the system design evolves."

\section{SITE REQUTREMENT SOURCE: DOE4700.1 Attachment III, Section 4.4.b}

-Test procedures. Test procedures are the basic documents of the project test program. They specify prerequisites, special equipment, precautions, and the steps to be followed during conduct of the test. Test requirements specify the testing to be performed and are used to prepare the detailed procedures for accomplishing testing."

\section{SITE REQUTREMENT SOURCE: DOEA700.1 Attachment III, Section 4.4.b(5)}

"Test Procedure Changes. Changes which unnecessarily increase the scope of existing procedures, and which are not required for safe operation or to correct errors, should not be submitted. Procedure change requests must be submitted to the plant contractor, must include the reason why the change is required, and must give a technical evaluation showing why the change is satisfactory. The contractor should obtain concurrence of the board in the need for a change prior to submitting the change request for approval."

SITE REQUTREMENT SOURCE: DOEA700.1 Attachment III-4.4.b.(1)(a) [2]

"These procedures are prepared by the contractor..."

SITE REQUIREMENT SOURCE: DOEA700.1 Attachment III-4.4.b.(1)(b) [1]

"The contractor develops test procedures using procedures or requirements contained in approved documents which are applicable to the equipment being tested, such as componeat technical manuals. 


\section{REQUIREMENTS IDENTIFICATION DOCUMENT \\ HIGH LEVEL WASTE STORAGE TANK FARMS \\ Research and Development and Experimental Activities \\ Revision 0}

SITE REQUIREMIENT SOURCE: DOEA700.1 Attachment III-4.4.b.(1)(b) [3]

"If approved documents do not contain the procedures required or if the contractor is uncertain as to which procedures in approved documents to uee, then the contractor submits recommended test procedures or teet requirements to DOE."

\section{SITE REQUIREMENT SOURCE: DOEA700.1 Attachment III-4.4.b.(1)(c) [1]}

"Where teat procedures to be isoued by the contractor provide for performance of operations in accordance with the component technical menual, the sections of the manual involved should be reproduced verbatim by the contractor and attached to or integrated into the test procedures, procediure changes, or procedures where the signoff of ateps is neceseary to provide a record of completion of teating."

SITE REQUIREMENT SOURCE: DOEA700.1 Attachment III-4.4.b.(1)(c) [2]

"If test procedures are retyped, each addition to component technical manual steps should be clearly marked as such and its source identified."

SITE REQUIREMENT SOURCE: DOEA700.1 Attachment III-4.4.b.(1)(c) [3]

"All reproductions or retyping of test procedures should be accomplished prior to presentation to the members of the testing review board."

SITE REQUIREMENT SOURCE: DOE4700.1 Attachment III-4.4.b.(1)(c)1

"If any caution statements in the plant or component technical manual procedures to be reproduced require a specific action to be performed, these cautions should be integrated into the test procedures as a procedural step."

STTE REQUTREMENT SOURCE: DOEA700.1 Attachment III-4.4.b.(1)(c)2

"One copy of the test procedures, including reproduced pages from the manual, should be designated the official record copy for concurrence by the testing review board."

SITE REQUIREMENT SOURCE: DOEA700.1 Attachment III-4.4.b.(1)(c)3 [1]

"Where circumstances are such that reproduction of sections of the manual involved is not practicable or desinable and applicable manual sections are merely referenced, the contractor shall determine an altermate method of maintaining an official status of accomplishment of the procedure, such as through use of the test monitor log."

SITE REQUTREMENT SOURCE: DOEA700.1 Attachment III-4.4.b.(1)(c)3 [2]

"In any oveat, the contractor shall assure that the sections of the manual involved are complete and compatible for use by the test monitor in performing the procedure."

SITE REQUTREMENT SOURCE: DOEA700.1 Attachment III-4.4.b.(1)(d) [1]

"Test procedures may be supplemented by test procedure addenda to specify such information 


\section{REQUIREMENTS IDENTIFICATION DOCUMENT HIGH LEVEL WASTE STORAGE TANK FARMS Research and Development and Experimental Activities Rerision 0}

as valve status and details for flushing or hydrostatic testing."

SITE REQUIREMENT SOURCE: DOEA700.1 Attachment III-4.4.b.(1)(d) [2]

"Local addenda may also be issued by the contractor to incorporate supplementary information from other approved documents."

STTE REQUIREMENT SOURCE: DOEA700.1 Attachment III-4.4.b.(1)(d) [3]

"Test procedure addenda are approved by the testing review board."

SITE REQUIREMENT SOURCE: DOEA700.1 Attachment III-4.4.b.(2)(a)1

"New project acceptance test procedures are endorsed and confirmed for performance on a specific project by means of an endorsing and confirming record which is prepared and approved as follows: Prepared by the project contractor"

\section{SITE REQUIREMENT SOURCE: DOEA700.1 Attachment III-4.4.b.(2)(a)4}

"New project acceptance test procedures are endorsed and confirmed for performance on a specific project by means of an endorsing and confirming record which is prepared and approved as follows: Distributed by the project contractor to the project manager and field organization."

\subsubsection{Records}

Sufficient records should be maintained to furnish evidence of activities affecting quality. The records should include at least the following: operating logs and the results of reviews, inspections, tests, audits, monitoring of work performance, and materials analyses. The records shall also include closely related data such as qualifications of personnel, procedures, and equipment. Inspection and test records should, as a minimum, identify the inspector or data recorder, the type of observation, the results, the acceptability, and the action taken in connection with any deficiencies noted. Records should be identifiable and retrievable.

Requirements for record retention, such as duration, location, and assigned responsibility shall be established.

\section{SITE REQUIREMENT SOURCE: DOEA700.1 Chapter III, Section D.2.q}

"Quality Assurance Records. Sufficient records should be maintained to furmish evidence of activities affecting quality. The records should include at least the following: operating logs and the results of reviows, inspections, tests, audits, monitoring of work performance, and materials analyses. The records shall also include closely related data such as qualifications of personnel, procedures, and equipment. Inspection and test records should, as a minimum, identify the inspector or data recorder, the type of observation, the results, the acceptability, and the action taken in connection with any deficiencies noted. Records should be identifiable and retrievable. Requirements for record retention, such as duration, location, and assigned responsibility shall be established."

\section{REVIEW AND EVALUATION OF RESULTS}

At the completion of individual tests or experiments, the results should be validated and 


\section{REQUIREMENTS IDENTIFICATION DOCUMENT HIGH LEVEL WASTE STORAGE TANK FARMS \\ Research and Development and Experimental Activities \\ Rerision 0}

documented: This validation should correspond to the WBS '...test and evaluation element..." described in Section 15.1.3.9. If necessary, provisions for retesting or performing additional experiments should be determined. If the individual test or experiment is part of a broader R\&D effort, the results should be evaluated to determine the change in experimental parameters for additional tests.

Preliminary results should be presented to the SRC: In perticular, any unexpected anomalies observed during the test need to be ovaluated. The Committee stould reevaluato the test if the experimental parameters are to be changed to conditions outside of the safety envelope initially approved by the SRC. Any change or adjustment in the test parameters and changes in the physical configuration of the facility or experimental setup will need to be documented. The evaluation of the test performance and test results should also include a determination of Unreviewed Safety Questions (USQ), if applicable, as described in the Nuclear Safety Functional Area. If at any time during the conduct of a test or experiment or during the evaluation of the test results the potential for a USQ is identified, an appropriate evaluation needs to be performed prior to proceeding with the experiment.

Test observations, measurements, and test results are analyzed and converted to information and data directed toward the objectives of the individual experiment or R\&D project. The root causes for unexpected results, test anomalies, and problems in conducting the experiment should be analyzed and corrective actions should be initiated, including potential retesting. Acceptable test results should be standardized when possible. Lessons leamed should be documented for consideration in the continuation or for future R\&D/EA activities. The test results and conclusions derived from the test should be compared with the goals initially established during the Project Proposal and the Concept and Feasibility Study phase to determine if the objectives were met.

SITE REQUTREMENT SOURCE: DOE4700.1 Attachment III, Section 4.4.b (6)

"Review of Completed Test Procedure. Following the performance of testing, the members of the board review and concur with the data for the completed test and sign to the effect that the test has been satisfactorily completed."

\section{SITE REQUIREMENT SOURCE: DOEA700.1 Chapter III, Section D.2.k [3]}

"Tests procedures should include provisions for assuring that all prerequisites for the given tests have been met, that adequate test instrumentation is available and used, and that each test is performed under suitable environmental conditions."

\section{SITE REQUIREMENT SOURCE: DOEA700.1 Chapter III, Section D.2.k [4]}

"Test results should be documented and evaluated to assure that test requirements have been satisfied."

\section{UTILIZATION OF RESULTS}

The entire R\&D/EA program effort from program inception through its completion should be documented in a report or as otherwise stipulated in the project proposal. Prior to the dissemination or utilization of test results and conclusions outside of the organization which performed the tests, they should be subjected to a review by a peer group which has the necessary expertise to evaluate and determine the adequacy and correctness of the performance 


\title{
REQUIREMENTS IDENTIFICATION DOCUMENT HIGH LEVEL WASTE STORAGE TANK FARMS \\ Research and Development and Experimental Activities
}

\author{
Revision 0
}

15.15.1

of the test, assumptions made, and results and conclusions. In the case of a single experiment, such peer review could be conducted by a co-worker not directly involved in the development of the concept or requirements of the test or in the performance of the test. For a major R\&D project, such peer reviess could be conducted by individuals who performed the initial Feasibility Study, by members of the Safety Review Committee (see ES\&H Functional Area of Nuclear Safety), or by another independent individual or group. The results, including objective and description of the test, should be considered for public release, pending the necessary security classification in accordance with the provisions of the Safeguards and Security Functional Area. Such release could be in scientific or technical journals, presentation at professional meetings, or in a special media release if warranted.

\section{Manngement Of Scientific And Technical Information}

DOE's Scientific and Technical Information (STI) management program consists of two parts which must be integrated to optimize the Department's information resources. DOE Order 1340.1A provides information regarding the Department's program-based mechanisms for STI management and oversight responsibilities, and detailed guidance for implementing DOE's centralized STI activities.

\section{SITE REQUIRENENT SOURCE: DOE1430.2B Chapter I.6.b}

"To achieve these goals, AD-21 will protect information that can be used to enhance U.S. competitiveness or national security to the extent permitted by U.S. law, Executive order, or other binding agreements. For example, certain types of technology transfer related information are exempt from requests under the Freedom of Information Act as provided for in the National Competitiveness Technology Transfer Act of 1989. Categories of technology transfer-related information include, but are not limited to, CRADAs, Small Business Innovation Research (SBIR) contracts, and patents."

\section{SITE REQUIREMENT SOURCE: DOEA700.1 Chapter I.C. 6.b.(13)}

"Heads of Field Elements shall: Assure the minimum technical reporting requirements of the Department are met and that all scientific, technical, and engineering publications are deposited in a timely fashion with the Office of Technical and Scientific Information"

\section{Submission of Scientific Or Technical Information}

Scientific and technical information may be reported in a variety of forms including: journal articles; reports; books; computer media; scientific/technical audio-visual or multimedia; and presentations at professional or scientific/technical conferences. Publication of articles in professional or technical society journals is encouraged. Documents that relate to activities involving protected intellectual property, copyrighted software, Protected CRADA Information, or other information with distribution release restrictions will receive appropriate protection by AD-21.

\section{STTE REQURREMENT SOURCE: DOE1430.2B Chapter IV.2}

"Basically, there are three types of scientific and technical reports:

a. Progress Reports (or Interim Reports) are reports that summarize on going work performed during a specific reporting period. A progress report is required on most projects at least once 


\section{REQUIREMENTS IDENTIFICATION DOCUMENT HIGH LEVEL WASTE STORAGE TANK FARMS \\ Research and Development and Experimental Activities \\ Revision 0}

during the fiscal year and may be required more frequently.

b. Topical Reports are comprehensive statements of the technical results of work performed on a specific task or phase of a contract. They also can be detailed descriptions of scientific or technological advances.

c. Final Reports are required for all completed research and development contracts, agreements, or financial assistance awards. These reports are technical accountings of the total work performed under the contract. They are comprehensive descriptions of the results achieved, which include tabulations of data, figures, photographs, and bibliographic citations in support of the investigations undertaken. Where applicable, they summarize all previous topical and progress reports. In some instances (e.g., university research), a summary of work covering the entire contract or grant period with open literature publications resulting from it identified as products may be accepted as a final report."

\section{SITE REQUIREMENT SOURCE: DOE1430.2B Chapter IV.6}

"Scientific or technical conferences,domestic or foreign, involving participation by DOE personnel, contractors or financial assistance recipients or for which DOE financial support is requested, are to be reported to AD-21 at the earliest possible time. Those reporting such conferences should complete the form entitled, "Information to be Announced in Energy Conferences and Symposia," (Attachment IV-2) which is included in the publication "Energy Conferences and Symposia." Additional forms are available from the Information Exchange and Standardization Division, AD-21. Copies of conference proceedings of DOE-sponsored conferences or meetings or copies of papers presented by DOE or DOE contractor personnel should be provided to AD-21. To ensure timeliness of DOE data bases and publications, preprints of conference papers should be provided to AD-21 whenever possible."

\section{SITE REQUIREMENT SOURCE: DOE1430.2B Chapter IV.7}

\section{" "WORK FOR OTHERS" PERFORMED AT DEPARTMENT OF ENERGY SITES.}

a. Unless otherwise specified in the agreement under which non-DOE work is performed (see DOE 4300.2B), the technical information generated under such agreements should also be transmitted to AD-21 using DOE F1332.15 (Attachment IV-1).

b. To ensure adequate coordination of DOE activities, unless otherwise specified in the agreement under which the non-DOE work is funded, Research-in-Progress information shall be submitted to AD-21 in accordance with provisions contained in Chapter II.

c. To ensure proper handling of this information, performing organizations shall conduct classification, patent, and sensitivity reviews in accordance with funding agency and DOE guidelines, and other statutes, laws, regulations, Executive orders and international agreements, as appropriate, prior to submitting the information to $\mathrm{AD}-21$."

\section{Special Requirements}

It is the policy of the Department to use the metric system in all activities, including procurement, consistent with statutory, operational, economic, technical, and health and safety considerations. It is the objective of the policy to pursue an orderly and coordinated transition to the use of the metric system in all the Department's activities, including procurement, in a 


\section{REQUIREMENTS IDENTIFICATION DOCUMENT HIGH LEVEL WASTE STORAGE TANK FARMS Research and Development and Experimental Activities Rerision 0}

manner consistent with Federal policy. Heads of field shall perform the following:

\section{SITE REQUIREMENT SOURCE: DOE5900.2A Section 8.b}

\section{"b. Heads of Headquarters Elements shall:}

(1) Develop a metrication program in their areas of responsibility. The scope and format of the plan shall conform to the guidelines prepared by AD-1. When use of the metric system for a specific project is not considered to be in the best interests of the Department, rationale for such a decision must be documented separately from the program plan.

(2) (Note: This paragraph is cancelled by DOE N 5900.2 dated 4-8-92.)

(3) (Note: This paragraph is cancelled by DOE N 5900.2 dated 4-8-92.)

(4) Convert design dimensions for existing facilities, systems, and equipment to metric only if it is determined to be necessary or advantageous; and, consider conversion when making significant modifications or during the normal update or revision cycle.

(5) Consider the metric system in developing applications to the specifications for procurement of all equipment, supplies, and services, particularly for new designs.

(6) Specify features on new equipment which will allow direct measurement in terms of metric units or both metric and inch-pound units and encourage use of metric conversion kits where available for existing equipment as necessary.

(7) Consider the metric system in proposal solicitation.

(8) Include the required resources in programming and budgeting actions to support efforts in converting to the use of the metric system. Use of the metric system shall be identified and planned so that costs can be minimized and resources included in the budget cycle on an orderly basis.

(9) Use of the metric system for reports and other measurement sensitive documentation. The corresponding inch-pound units may be listed in parentheses or the appropriate conversion factors to customary units may be listed.

(10) Convert or develop metric specifications, standards, and other general purpose technical documents and data to keep pace with the transition in the industrial, public, and private sectors or international area.

(11) Promote the development of applicable metric requirements, specifications, and standards as the need arises for items without commercial counterparts.

(12) Provide personnel to participate in the development of national and international standards and recommendations using the metric system to the extent indicated by the Department's interests and in accordance with the Department's standards policy.

(13) Support the Department's Metric Coordinator in providing coordination and liaison within the Department and other governmental or nongovernmental groups involved in metrication in order to facilitate the transition in the energy sector. 


\section{REQUIREMENTS IDENTIFICATION DOCUMENT \\ HIGH LEVEL WASTE STORAGE TANK FARMS \\ Research and Development and Experimental Activities \\ Revision 0}

(14) Participate on a reasonable basis in support of extramural metrication programs; for example, community activities, oducational programs, and those in which an organizational element can make a worthwhile contribution to the national use and understanding of the metric system.

(15) Assure training in metric practices and usage for those personnel whose duties require such knowledge or where training will facilitate productivity.

(16) Foster and encourage the use of the metric system:

(a) In areas where industry has made significant progress in metric conversion and where production facilities are available.

(b) Where there is a specific need as for materials hardware, or systems used in conjunction with international activities.

(c) In all data systems and processes, including automatic data processing systems, that are measurement sensitive.

(d) In other areas which offer an economic, operational, or other advantage or where no disadvantage is incurred.

(17) Designate a representative to serve on the Department's Metric Transition Committee and to coordinate metrication within the organizational element. Metric coordinators may also be designated, as deemed appropriate, for offices, divisions, and other major organizational elements below the assistant secretary level to serve as the focal points for metrication activities within the organizations."

\section{DISMANTLING AND DISPOSITION}

Upon the completion of R\&D or EA activities, evaluation of results, peer review, and possible public dissemination of the results and conclusions, a determination should be made regarding any potential future use of the R\&D prototype or the experimental setup. For the latter case, which generally involves limited equipment, space, and expenditures, the most cost-effective approach normally is the complete dismantling of the experiment. Reusable resources (equipment, space, and materials) should be cleaned and decontaminated as necessary. The capability for reuse should be certified. The resources should be inventoried and stored in a safe condition for reuse.

Prior to dismantling major R\&D projects, a determination should be made for the potential future use for similar or other R\&D efforts. The potential for interim maintenance in a stable condition should be considered. If it is concluded that there is no potential future use for the facility, a plan for the partial or complete dismantling of the facility should be developed. This will include provisions for material control and handling, residue and waste disposal, and site restoration. Specific provisions in the Functional Area of Environmental Restoration and Waste Management have not been developed at this time, since it has been determined that D\&D is not applicable during the operations phase of the Tank Farms Facilities. However, for R\&D/EA projects, D\&D will be required as experimental projects are completed. Section 15.10.4 overviews requirements to be considered during the design phase of individual R\&D/EA projects. 


\section{REQUIREMENTS IDENTIFICATION DOCUMENT \\ HIGH LEVEL WASTE STORAGE TANK FARMS \\ Research and Development and Experimental Activities \\ Revision 0}

15.17

15.17 .1

$\underline{15.17 .2}$

15.17 .3

15.17 .4

15.17 .5

\section{KEY PROGRAM NTERFACES}

The R\&D/EA Functional Area interfaces with the other functional areas, depending upon the type and scope of R\&D/EA program. The programmatic controls of these functional areas are applicable to R\&D/EA activities using a graded approach. Particular aspects for key interfaces are described below.

\section{Configuration Management}

The programmatic controls of the Configuration Management Functional Area should be applied to R\&D/EA programs. Because of the experimental nature of R\&D/EA activities, the systems, equipment, and operating conditions are frequently modified to meet new and revised objectives. Therefore, it is essential that any changes to the configuration of the facility be documented in order to maintain the configuration up to date.

\section{Engineering Design}

The programmatic controls of the Engineering Design Functional Area apply to the R\&D/EA programs, in particular where such programs involve the design and construction of a major new R\&D facility. Experimental programs frequently involve activities under extreme conditions. It is essential that the engineering design consider these extreme conditions with respect to equipment, material capability, and operability. In particular, the use of a R\&D facility or of an experimental setup outside of the original design basis should be considered by the SRC to ensure that the safety envelope is not exceeded.

\section{Emergency Preparedness}

The programmatic controls of the Emergency Management Functional Area are applicable to R\&D/EA programs. The potential use of hazardous materials with undetermined characteristics or unknown consequences and of equipment under uncertain basis should be considered in the development of the emergency plan, for example, with respect to protective clothing and emergency evacuation routes.

\section{Management Systems}

The programmatic controls of the Management Systems Functional Area are applicable to R\&D/EA programs. Because of the highly diverse and unique activities performed at $R \& D / E A$ facilities, clear management responsibilities and authorities should be defined for each activity. Such programmatic controls should include consideration for not unnecessarily impacting the performance of experimental investigation.

All information and records developed during the conduct of the R\&D/EA program should be identified, collected, documented and stored in accordance with the Document Control and Records Management as detailed in the Functional Area of Management Systems. The method, location, and duration for record retention should be identified and implemented. Specific considerations for external dissemination of $R \& D / E A$ results should be consistent with Section 15.15 .

\section{Occupational Safety and Health (OSH)}

The programmatic controls detailed in the OSH Functional Area are applicable to R\&D/EA 


\section{REQUIREMENTS IDENTIFICATION DOCUMENT HIGH LEVEL WASTE STORAGE TANK FARMS \\ Research and Development and Experimental Activities \\ Revision 0}

programs. Special considerations should be given to OSH programs for R\&D/EA facilities if unknown or unidentified hazardous substances are used or if unusual operating conditions can be anticipated.

\section{Snfequards and Security}

The programmatic controls detailed in the Safeguards and Security Functional Area are applicable to R\&D/EA programs. The S\&S provisions apply not only to the conduct of R\&D/EA activities, but also include the results of such programs. Data and conclusions resulting from R\&D/EA programs need to be reviewed to determine if they can be publicly released.

\section{Trainine and Qualification}

General staffing and training considerations are detailed in the Functional Area of Training and Qualification. R\&D/EA programs encompass a wide spectrum of activities which require personnel that is uniquely qualified and experienced in the specific aspects of these activities so that they are conducted in a safe, reliable and efficient manner. The qualification and training of personnel for R\&D/EA activities should be commensurate with the hazards of these activities to ensure the health and safety of the workers and the public and to ensure the protection of the environment.

Specific examples are training for handling of unknown and unidentified substances, of chemicals, toxic materials and radioactive materials, training for emergency conditions and actions, and training in the use of special tools and equipment. Specific training requirements should be reviewed by the Safety Review Committee (SRC). 


\section{WESTINGHOUSE HANFORD COMPANY}

\section{REQUIREMENTS}

\section{IDENTIFICATION}

\section{DOCUMENT}

EACILITY:

EUNCTIONAL AREA:

HIGH LEVEL WASTE STORAGE

TANK FARMS/242-A

EVAPORATOR

Nuclear Safety

\section{REVISION 0}




\section{REQUIREMENTS IDENTIFICATION DOCUMENT \\ HIGH LEVEL WASTE STORAGE TANK FARMS \\ Nuclear Safety \\ Reviaion 0}

\section{TABLE OE CONTENTS}

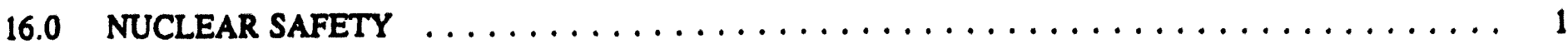

16.1

16.1.1

16.1 .2

16.1.3

16.1 .4

16.2

16.2 .1

16.2 .2

16.2 .3

16.3

16.3 .1

16.3.2

16.3.3

16.3.4

16.4

16.4.1

16.4 .2

16.4 .3

16.5

16.5.1

16.5 .2

16.5 .3

16.5.4

16.6

16.6.1

16.6 .2

16.6 .3

16.6.4

16.7

PROGRAM MANAGEMENT $\ldots \ldots \ldots \ldots \ldots \ldots \ldots \ldots \ldots \ldots$

Training and Qualification $\ldots \ldots \ldots \ldots \ldots \ldots \ldots$

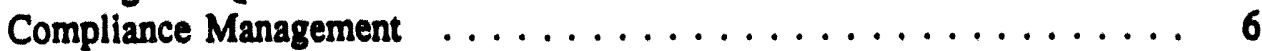

Self-Assessment Process ....................... 9

Documentation ....................... 11

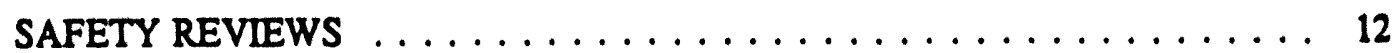

Independent Review Process $\ldots \ldots \ldots \ldots \ldots \ldots \ldots \ldots$

Operations Review Committee . . . . . . . . . . . . . 14

Safety Oversight Committee .................... 18

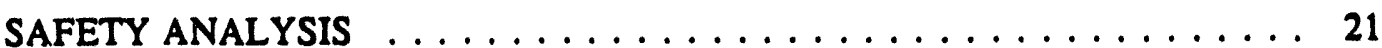

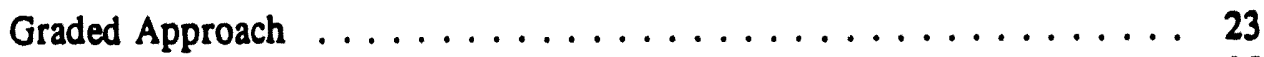

Safety Analysis Report Process . . . . . . . . . . . . . . . 25

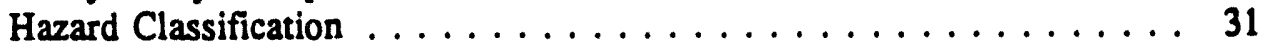

Operational Limits . . . . . . . . . . . . . . . 33

TECHNICAL SAFETY REQUIREMENTS . . . . . . . . . . . . . 33

Procedures To Implement the TSR Process $\ldots \ldots \ldots \ldots \ldots \ldots$

TSR Document . . . . . . . . . . . . . . . . . . 35

Review and Approval of a TSR Document . . . . . . . . 38

UNREVIEWED SAFETY QUESTIONS . . . . . . . . . . . . . . . . . . 39

Development of USQ Training and Controls . . . . . . . . . . . 40

USQ Determination . . . . . . . . . . . . . . . . . . 44

Notifications, Evaluations, and Actions . . . . . . . . . 49

Documentation .................... 50

NUCLEAR CRITICALITY SAFETY . . . . . . . . . . . . 51

Design Practices $\ldots \ldots \ldots \ldots \ldots \ldots \ldots \ldots \ldots \ldots \ldots \ldots$

Materials Control ..................... 57

Emergency Planning .................... 57

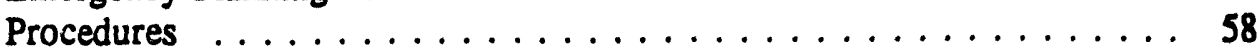

KEY PROGRAM INTERFACES $\ldots \ldots \ldots \ldots \ldots \ldots$ 


\section{REQUTREMENTS DENTIFICATION DOCUMENT \\ HIGH LEVEL WASTE STORAGE TANK FARMS \\ Nuclear Safety \\ Revision 0}

\subsection{NUCLEAR SAFETY}

\section{INTRODUCTION}

\section{SCOPE}

This Requirements Identification Document (RID) describes a Nuclear Safety(NS) program as defined through the relevant DOE Orders, regulations, industry codes/standards, industry guidance documents and, as appropriate, good industry practice. The definition of a program as specified by this document is intended to address Defense Nuclear Facilities Safety Board Recommendations 90-2 and 91-1, which call for the strengthening of DOE weapons complex activities through the identification and application of relevant standards which supplement or exceed requirements mandated by DOE Orders.

The Nuclear Safety program defined in this document is presented in the form of program elements and sub-elements. The descriptive text specifies the programmatic controls necessary for implementation of each element and sub-element. The specific DOE Orders, regulations, industry codes/standards, guidance documents and good industry practices which serve as the basis for each element/sub-element are identified and aligned with each sub-element.

It is intended that this document be used as a baseline from which to compare the existing Nuclear Safety Program for determination of the level of program definition and maturity including the existence of an overall site infrastructure and clearly defined interfaces with other relevant functional areas. Additionally, this RID may be used as the basis against which future program definition and improvement efforts, including procedures development and/or revisions, can be compared to ensure consistency, completeness and proper integration with other functional programs.

This RID applies to all activities performed at or in conjunction with the operation and maintenance of the Tank Farms Facilities and Operations at Westinghouse Hanford Company.

This RID applies to the activities, personnel, structures, systems, components, and programs involved in executing the mission of the Tank Farms. The physical boundaries within which the requirements of this RID apply are the Single Shell Tank Farms, Double Shell Tank Farms, 242-A Evaporator-Crystallizer, 242-S,T Evaporators, Tiquid Effluent Retention Facility (LERF), Purgewater Storage Facility (PWSF), and all interconnecting piping, valves, instrumentation, and controls. Also included is all piping, valves, instrumentation, and controls up to and including the most remote valve under Tank Farms control at any other Hanford Facility having an interconnection with Tank Farms. The boundary of the structures, systems, components, and programs to which this RID applies, is defined by those that are dedicated to and/or under the control of the Tank Farms.

The Nuclear Safety Functional Area is based on DOE Orders 5480.5, 5480.21, 5480.22, 5480.23, and 5480.24. In addition, DOE/EH-0135 "PERFORMANCE OBJECTIVES AND CRITERIA FOR TECHNICAL SAFETY APPRAISALS AT DOE FACILITIES AND SITES" provides added safety objectives and criteria to be evaluated. Those DOE/EH-0135 requirements marked with an asterisk (*) are those required to be appraised by the technical safety appraiser. 


\section{REQUIREMENTS IDENTIFICATION DOCUMENT \\ HIGH LEVEL WASTE STORAGE TANK FARMS \\ Nuclear Safety \\ Revicion 0}

The Nuclear Safety Functional Area includes program elements that are necessary to assure that nuclear operations at DOE facilities are conducted safely, effectively, and in accordance with specified DOE requirements and selected industry codes, standards, and guidelines.

1. Program Management

2. Safety Reviews

3. Safety Analysis

4. Technical Safety Requirements

5. Unreviewed Safety Questions

6. Nuclear Criticality Safety

7. Key Program Interfaces

\section{SITE REQUTREMENT SOURCE: DOENS480.5 Polley}

"It is the policy of the Departmeat of Energy (DOE) that its nuclear facilitios be designed, constructed, and operated in a manner that presents no undue risk to the health and safety of personnel or to the surrounding communities. DOE specifies requirements applicable to the design, construction, and operation of its facilities to ensure an adequate level of safety. DOE routinely reevaluates and modifies these requirements, or devolops new requirements, in order to reflect new information bearing upon the safoty of DOE facilitios which may come to light as a recult of new research, the accumulation of operating experience, specific incidents at DOE or other facilities, or from other sources.

This Notice establishes a process governing the imposition of proposed nuclear safety requirements at DOE nuclear facilities. This process is intended to ensure that necessary requirements are implemented in a manner which is coordinated with other safety-significant work. It is also intended to ensure that proposed requirements which may not be appropriate for imposition at individual facilities or groups of facilities are identified and evaluated. Proposed requirements determined to bo inappropriate are not to be implemented so that the resources which they would require may be applied to other activities which will result in safety improvements.

It shall be DOE policy to assess each proposed nuclear safety requirement to determine whether it should be imposed. Those proposed requirements found necessary to ensure adequate protection of health and safety and those needed to facilitate DOE management of the safety of its facilities shall be implemented. Other proposed requirements shall be assessed to determine whether implementation is likely to result in safety improvements which justify the resource expenditures and management impacts associated with their implementation. These assessments shall include generic considerations by DOE, as appropriate, and evaluations by contractors that consider facility-specific factors relovant to each proposed requirement. The results of contractor evaluations shall be subject to DOE approval. The attached procedure shall be used to conduct these assessments. Proposed requirements which are found likely to produce safety improvements commensurate with related costs shall be implemented on a schedule which is 


\section{REQUIREMENTS IDENTIFICATION DOCUMENT HIGH LEVEL WASTE STORAGE TANK FARMS Nuclear Safety Reviaion 0}

consisteat with their relative affety importance. See Attechmeats 1 and 2.

The provisions of this Notice apply to all Departmeatal Elomeats and to covered contractors to the extent implemented under a contriet or other agreement. A covered contractor is a seller of suppliee or services involving the design, construction, operation or docommisvioning of a nuclear facility under a managemeat and operating contract. The provisions of this Notice do not apply to those facilities and activities under Executive Order 12344 and Public Law 98-525 (42 U.S.C. 7158, noto)."

\section{FACILITY REQUTREMENT SOURCE: DOE-SEN-35-91 POlley}

-It is the policy of the Department of Energy (DOE) that the general public be protected such that no individual beare aignificant additional risk to health and anfery from the operation of a DOE nuclear facility above the risks to which members of the general population are normally expoed. The purpose of this document is to establish the basic nuclear afoty policy from which specific safety rules, orders, standards, and other requirements shall follow." DOE facilities will be designed, constructed, operated, and decommissioned to assure the protection of the public, workers, and the environment.

To implement this policy, DOE and its contractors shall: 1) establish and maintain management involvement and accountability to ensure that nuclear safety requirements are met and individual responsibility is articulated and unc-rtood by all parties; 2) develop and foster technically competent personnel and the technical standards necessary to achieve nuclear safety; 3) uso established nuciear safety goals to servo as aiming points for performance; 4) establish and maintain vigorous oversight to assure adherence to this policy and its implementing directives; and 5) promote a culture that is dedicated to continuously striving to enhance nuclear safety.

The Department intends to implement this policy to foster an ethic of continuous improvement of nuclear safety at DOE facilities. This othic will be characterized by a more disciplined approach to management and operations, sounder tochnical bases for decisions and actions, greater tochnical inquisitiveness, and more rigorous self-assessment. A safety culture based on this openness to criticism is necessary to assure that the Department adequately protects the bealth and safety of the public, DOE and contractor employees, and the environment.

The Department will issue a set of Orders, rules, and safety guides to eatablish nuclear safety requirements. which will implement this policy. The objective is to achieve a coherent and cohesive set of nuclear safety requirements. The Assistant Secretary for Nuclear Energy is directed to assure that this result is achieved and to establish an independent review process to verify such a result." 


\section{REQUTREMENTS IDENTUICATION DOCUMENT HIGH LEVEL WASTE STORAGE TANK FARMS Nuclear Safety \\ Reriaion 0}

This dement addrewees the unique apects of project management that are in cenential part of an effective Nuclear Safety (NS) Program. The general apects of management, policy, ataffing, and training ase covered in the Mrangemeat Systems Functional Area. A formal Nuclear Safety Program earures that a deliberate and controlled approsch to Program management and execution is schieved. Establishmeat of such a formal Program eahances the potential for achievement of high levels of safety performance and efficiency.

\section{FACLITY REQUIREMENT SOURCE: DOE-SEN-35-91 Section 1}

\section{"MANAGEMENT}

The Secretary of Energy has overall responsibility for the anfety of DOE facilities. DOE line managers report to the Secretary and are directly responsible and accountable for the safety of their activities. Clear lines of authority and responsibility for ensuring afety will be ectablishod and maintained at all levels of DOE and contractor organizations. Clear and adequate guidance stall be provided by DOE line menagers to their contractors including the need for management to maintain a proper balance of anfoty, production goals, and cost considerations which ensures that anfety is fully integrated into every level of activity. DOE line management is responsible for defining appropriate safety objectives for its facilities, and contractor management is responsible for meeting those objectives, instilling a philosophy of personal excellence, and timely identification and resolution of safety problems. DOE and contractor management are responsible for continuously pursuing enhancements to safety-not just complying with a minimal set of requirements.

To ensure full responsibility for nuclear safety, DOE will require that all contractors' activities be conducted in accordance with all DOE rules, regulations, and Orders relating to nuclear safety. Contractor responsibility for the safety of its activities does not in any way relieve, diminish, or abrogate DOE managers of the responsibility for assuring safety through proper decision-making, planning, direction, and oversight. Safe operations, environmental protection, and meeting production and research goals are mutually achievable objectives. Assurance of adequate safety will not be compromised to achieve production or research objectives."

\section{FACIIITY REQUIREMENT SOURCE: DOE-SEN-35-91 Section 5}

\section{-SAFETY CULTURE}

Achieving continuous improvement in nuclear safety requires a culture that encourages setting and maintaining high stendards; identifying and resolving problems and deficiencies; openness to criticism and recommendations for improvement; and mutual respect and effective communication between line managers and independent oversight. 


\section{REQUTREMENTS IDENTIFICATION DOCUMENT \\ HIGH LEVEL WASTE STORAGE TANK FARMS \\ Nuclear Safety \\ Reviaion 0}

This culture can only be established if menagement is fully committed to its nuclear eafety reoponsibilities. It is DOE policy to eatablish and maintain such a culture."

\section{Trainine and Qualincation}

General training and qualification program controls (wuch as personnel qualification, selection, training, and certification, including requalification, recertification and continued training) are addressed in the Management Systems and the Training and Qualification Functional Areas. In addition, a training program for NS personnel should be developed to include nuclear safety training for individuals who operate, maintain, and supervise activities in nuclear facilities, including fissionable material hendling. The program should also includo training in: risks associated with facility operation; location and functions of pertinent sefety systems; configuration control procedures; operational safety requirements; response to nuclear criticality safety alarms; critical conditions that cold result from fire fighting operations where water is used; and Unreviewed Safety Question (USO) determination.

\section{FACIITY REQUIREMENT SOURCE: DOE-SEN-35-91 Section 2}

\section{"TECHNICAL COMPETENCE}

The scientific, engineering, and technical knowledge and ability of DOE and its contractor personnel directly determine the Department's ability to achieve its safety policy. Potential hazards associated with nuclear operations dictate that DOE and contractor personnel possess technical competence, commitment, discipline, and high standards of professional and personal excellence. Organizations responsible for DOE nuclear activities shall have the ability to recruit, train, and qualify personnel who possess these attributes for job specific positions.

Adherence to appropriate national and international standards in the design, construction, operation, and decommissioning of DOE's nuclear facilities and activities is necessary for the successful implementation of the Department's nuclear safety policy. Standards proven through years of experience and accepted by professional and technical societies shall be used wherever applicable. Yet no matter how carefully conceived and properly developed, technical standards cannot address all eventualities.

Therefore, DOE contractors must critically assess the standards in use at DOE facilities to assure that they remain consistent with the latest information arising from operational experience and developments in science and engineering. Where standards do not exist or where existing standards do not suffice, appropriate DOE nuclear safety standards shall be doveloped and adopted."

\section{SITE REQUIREMENT SOURCE: DOE5480.5 Section 9.d}

"Provides technical competence in the areas being reviowed. Each review, except that described in subparagraph 9i, below, shall be carried out by persons whose technical disciplines cover the range of technical fields encountered in performing a safety review. Safety considerations are to be treated in the breadth and depth necessary to identify potential hazards and to evaluate the risks." 


\section{REQUIREMENTS IDENTIFICATION DOCUMENT \\ HIGH LEVEL WASTE STORAGE TANK FARMS \\ Nuclear Safety \\ Reviaion 0}

STIE REQUIREMENT SOURCE: DOES700.6C Section 9.b(1)(b)

"Criterion 2 - Personnel Training and Qualification. Personnel shall be trained and qualified to ensure they are capable of performing their assigned work. Pereonnel shall be provided continuing training to ensure that job profisiency is maintained."

\section{1 .2}

\section{Compliance Management}

This management review process is to ensure compliance with DOE Orders, industry standards, laws, directives, regulations and guidelines should be integrated into the NS Program to ensure protection of the public health and safety from the risks of hezardous and radioactive materials. When a potential nuclear safety issue is discovered, a USQ determination should be performed to determine the safety significance, and the facility should be put in a safe condition. Details of this process are covered in the Compliance Management subelement of the Management Systems Functional Area.

\section{SITE REQUIREMENT SOURCE: DOE-N5480.5 Attachment 1, Section 6}

"Backfit Analyses by Contractors and Implementation Plans.

a. Conduct of Analyses. The DOE contractor responsible for each facility on which a backfit is imposed shall conduct a systematic and documented analysis of all requirements not considered invariant pursuant to Paragraph 4 of this procedure. This analysis is to be judgmental and guided by available quantitative information. The analysis shall consider the potential for the objectives of the proposed backfit to be met by other activities or features at the facility and shall also document consideration of the factors listed in Attachment 2 to this procedure.

b. Preparation of Implementation Plans. Bed on the results of the analysis conducted in accordance with Paragraph 6a, the contractor is to propose an implementation plan. For each requirement not categorized as invariant, this implementation plan shall:

(1) commit to iruplement the requirement without change,

(2) propose a modified implementation of the requirement to accommodate facility-specific circumstances, or

(3) justify not implementing the requirement based upon facility-specific reasons.

c. Approval of Analyses and Implementation Plans.

(1) The contractor's backfit analysis and the implementation plan derived from it are to be submitted to the DOE Program Secretarial Officer (PSO) responsible for each facility. DOE approval of each such plan shall be documented, described the basis for the approval. 


\section{REQUIREMENTS IDENTIFICATION DOCUMENT HIGH LEVEL WASTE STORAGE TANK FARMS Nuclear Safety \\ Reviaion 0}

If the DOE finds a backfit implementation plan unacceptable, the PSO may return it to the contractor with written direction for modifying the plan so that it can be approved by DOE. In such instances, the contractor shall modify the plan and resubmit it for approval. DOE may, altematively, modify and approve the plan without further contractor involvement. A contractor's implementation plan shall be considered approved 180 days after submittal unless it is approved or rejected by the DOE at an earlier date. The elements of an approved implementation plan are to be considered as requirements binding upon the operating contractor in the same manner as the underlying rule, regulation, Order or other requirement to which they relate.

(3) Once approved, a backfit implementation plan may not be changed unless factors considered in the original analysis conducted pursuant to this Notice have changed sufficiently to change the conclusions of that analysis. In such cases, a revised implementation plan and revised analysis shall be submitted to the DOE for approval and shall be reviewed and approved in the same manner as an original analysis and plan."

\section{SITE REQUIREMENT SOURCE: DOE-N5480.5 Attachment 1, Section 7}

"Implementation Schedules.

a. The contractors responsible for each facility on which a backfit is imposed shall propose a schedule for implementing each such backfit (except for excluded or invariant requirements for which fixed implementation schedules have been imposed). The proposed schedule is to take into consideration the relative safety priority of the backfit compared to other work planned for the facility and the available to support this work.

b. The proposed implementation schedule is to be submitted to the DOE for approval along with the implementation plan and analysis required by Paragraph 6 of this procedure. DOE approval of each such schedule shall be documented, describing the basis for the approval.

c. If the DOE finds a backfit implementation schedule unacceptable, it may be returned to the contractor with written direction for modifying the schedule so that it can be approved. In such instances, the contractor shall modify the schedule and resubmit it for approval. DOE may, alternatively, modify and approve the schedule without further contractor involvement. A contractor's proposed implementation schedule shall be considered approved 180 days after submittal unless it is approved or rejected by the DOE at an earlier date.

d. Implementation schedules may be revised as necessary to reflect addition or deletion of other safety work at a facility or other factors which affect the ability to meet the approved schedule. Revised implementation schedules shall be submitted to the DOE for 


\section{REQUIREMENTS IDENTIFICATION DOCUMENT \\ HIGH LEVEL WASTE STORAGE TANK FARMS Nuclear Safety \\ Reviaion 0}

approval along with justification for the revision and shall be reviewed and approved in the same manner as an original schedule. Proposed revised imp! imentation schedules will not be effective until approved by DOE. An approved implementation schedule shall be considered as a requirement binding upon the operating contractor."

\section{SITE REQUIREMENT SOURCE: DOE-N5480.5 Attachment 2}

\section{"FACTORS TO CONSIDER IN BACKFIT ANALYSES}

Analyses conducted pursuant to this procedure shall consider information available concerning any of the following factors as may be appropriate and any other information relevant and material to the proposed backfit:

1. the specific objectives that the proposed backfit is designed to achieve;

2. the specific activities that will be required to implement the proposed backfit;

3. the potential change in risk to the public or to facility staff from the accidental release of radioactive or hazardous materials;

4. the potential impact on exposure of facility employees to radiation, radioactivity, hazardous materials, or occupational safety hazards;

5. the installation and continuing costs associated with the proposed backfit;

6. the potential impact of facility downtime associated with implementing the backfit, including potential impact on programmatic missions;

7. the potential safety impact of changes in facility or operational complexity, including the relationship to proposed and existing regulatory requirements; and

8. the potential impact of differences in facility type, design, or remaining operational lifetime on the relevancy and practicality of the proposed backfit."

\section{FACILITY REQUIREMENT SOURCE: DOE5480.5 Section 8.b}

"Administrative and procedural controls that delineate (1) clear lines of responsibility and methods for safe operation under normal and emergency conditions, and (2) a system of configuration control that requires independent safety review and approval of all changes to components, equipment, procedures and systems required for facility safety." 


\section{REQUIREMENTS IDENTIFICATION DOCUMENT \\ HIGH LEVEL WASTE STORAGE TANK FARMS \\ Nuclear Safety \\ Reviaion 0}

SITE REQUIREMENT SOURCE: DOE5480.5 Section 8.e

"BASIC REQUIREMENTS. The environment, safety, and health program for nuclear facilities shall include the following:

e. A quality assurance program in accordance with DOE 5700.6B."

\section{SITE REQUTREMENT SOURCE: DOE5480.5 Section 8.i}

"Basic Requirements. The environment, safety, and health program for nuclear facilities shall include the following:

i. For new nuclear facilities and for significant modifications to existing nuclear facilities, reviews and inspections during construction, acceptance of systems, and preoperational phases to assure compliance with the appropriate ES\&H standards and requirements."

\section{1 .3}

\section{Self-Assessment Process}

The NS Program should be reviewed and evaluated by its management on a routine basis to ensure that the functions of its subelements are being adequately implemented. The general guidelines associated with the self-assessment process are addressed in the Self-Assessment subelement of the Management Systems Functional Area.

\section{SITE REQUIREMENT SOURCE: DOE/EH0135 FR.4}

\section{"FR.4 ANNUAL FACILITY SAFETY REVIEW}

PERFORMANCE OBJECTIVE: An annual operating review of the facility should be performed by a committee appointed by top contractor management as specified in DOE 5480.5 and DOE 5480.6."

\section{SITE REQUIREMENT SOURCE: DOE/EH0135 FR.4.1}

"*1. Areas covered by the annual review include:

- Modifications made to facilities and equipment having safety

significance and safety analyses thereof;

- Proposed experiments and irradiations having safety significance;

- Procedures and significant changes thereto;

- Performance of training programs;

- Adherence to nuclear criticality safety program requirements;

- Occurrences; all Unusual Occurrence Reports (UORs);

- The condition of the physical facilities;

- Organization and staffing; 


\section{REQUIREMENTS IDENTIFICATION DOCUMENT HIGH LEVEL WASTE STORAGE TANK FARMS \\ Nuclear Safety \\ Reviaion 0}

- Accuracy and completeness of records and documentation; and

- Vital operational and maintenance activities."

SITE REQUUREMENT SOURCE: DOE/EH0135 FR.4.2

"2. Top contractor management documents the assignment of personnel for the annual review."

\section{SITE REQUIREMENT SOURCE: DOE/EH0135 FR.4.3}

"3. The individuals performing the annual review are not the same as those who review safety questions."

\section{SITE REQUIREMENT SOURCE: DOE/EH0135 FR.4.4}

"4. The annual review must be documented so that an adequate third party review can be conducted."

SITE REQUIREMENT SOURCE: DOE/EH0135 FR.4.5

"5. Review methods and emphasis are varied from year to year to avoid continually looking at the same topics in the same way.

\section{SITE REQUIREMENT SOURCE: DOE/EH0135 FR.4.6}

"6. Outside consultants are periodically added to the annual review to provide different perspectives."

\section{SITE REQUIREMENT SOURCE: DOE/EH0135 FR.5}

"FR.5 TRIENNIAL APPRAISAL OF SITE/FACILITY SAFETY REVIEW SYSTEM

PERFORMANCE OBJECTIVE: A triennial appraisal of the safety review system should be performed by contractor management."

\section{SITE REQUIREMENT SOURCE: DOE/EH0135 FR.5.1}

"*1. The frequency between appraisals is consistently less than $\mathbf{4 2}$ months."

\section{SITE REQUIREMENT SOURCE: DOE/EH0135 FR.5.2}

"2. A reviewer or a committee is appointed by management to conduct triennial appraisals."

\section{SITE REQUIREMENT SOURCE: DOE/EH0135 FR.5.4}

4. Interviews with site/facility personnel indicate that the Safety Review Committee and the safety review system are effective and respected." 


\section{REQUIREMENTS IDENTIFICATION DOCUMENT HIGH LEVEL WASTE STORAGE TANK FARMS Nuclear Safety \\ Reviaion 0}

\section{SITE REQUIREMENT SOURCE: DOE/EH0135 FR.5.5}

"5. Documentation of the triennial appraisal is adequate for a third-party review of the quality of content."

\section{SITE REQUIREMENT SOURCE: DOE/EH0135 FR.5.6}

"6. Methods used for the conduct of triennial appraisals provide an independent assessment of the effectiveness of the safety review system."

\section{SITE REQUIREMENT SOURCE: DOE/EH0135 FR.5.7}

7. Appraisals address the adequacy and performance of the management systems established for independent safety review."

\section{SITE REQUIREMENT SOURCE: DOE5480.5 Section 9.i}

"Criticality safety program shall be reviewed by management for adequacy of performance every 3 years, or more often, as required.

Review the overall operation of each facility with sufficient frequency to assure adequate ES\&H coverage."

\section{SITE REQUIREMENT SOURCE: DOE5700.6C Section 9.b(1)(c)}

"Criterion 3 - Quality Improvement The organization shall establish and implement processes to detect and prevent quality problems and to ensure quality improvement. Items and processes that do not meet established requirements shall be identified, controlled, and corrected. Correction shall include identifying the causes of problems and preventing recurrence. Item reliability, process implementation, and other quality-related information shall be reviewed and the data analyzed to identify items and processes needing improvement."

Documentation

Documentation of the Management/Administration, Safety Reviews, Safety Analysis, Technical Safety Requirements, Unreviewed Safety Questions and Nuclear Criticality Safety areas will be maintained. These records may be kept either as a part of the individual program or under an overall program under the Management/Administration area.

\section{SITE REQUIREMENT SOURCE: DOE5480.5 Section 8.j}

"A formal documented system for the control and traceability of records and documentation specified herein." 


\section{REQUIREMENTS IDENTIFICATION DOCUMENT \\ HIGH LEVEL WASTE STORAGE TANK FARMS \\ Nuclear Safety \\ Reviaion 0}

SITE REQUIREMENT SOURCE: DOE5480.5 Section 9.h(9)

"Provides for objective and independent roview of:

(9) The accuracy and completeness of record keeping and documentation."

\section{SAFETY REVIEWS}

Safety reviews are performed as described in the following subelements. These include Reviews and Inspections, the Operations Review Committee, and the Safety Oversight Committee.

\section{SITE REQUIREMENT SOURCE: DOE/EH0135 FR.1}

\section{"FR.1 SAFETY REVIEW COMMTTEE}

PERFORMANCE OBJECTIVE: A Safety Review Committee should be available to review safety questions and the safety impacts of experiments. This committee is part of the "Contractor Independent Review and Appraisal System" specified in DOE 5480.5, or DOE 5480.6, and/or DOE 5482.1B., Section 9.d."

\section{SITE REQUIREMENT SOURCE: DOE5480.5 Section 8.m}

"A contractor independent safety review and appraisal system which meets the requirements of paragraph $9 . "$

\section{SITE REQUIREMENT SOURCE: DOE5480.5 Section 9, Opening Statement}

"Each contractor to whom this Order is made applicable shall establish and maintain an internal safety review system for nuclear facilities" "

\section{Independent Review Process}

Safety analyses, design criteria, environmental assessments and impact statements, and other design documents should be reviewed for adequacy and correctness from a safety perspective. Programmatic controls should be established to ensure that inspections and reviews are performed as neceasary during the construction, acceptance, and preoperational phases of a facility or process.

\section{SITE REQUIREMENT SOURCE: DOE/EH0135 FR.1.1}

"*1. The Safety Review Committee (SRC):

- Is appointed by management;

- Functions in an advisory capacity to management;

- Has a written charter which specifies its responsibility, authority, composition, quorum, documentation of efforts, and reporting requirements; 


\section{REQUIREMENTS IDENTIFICATION DOCUMENT HIGH LEVEL WASTE STORAGE TANK FARMS Nuclear Safety \\ Reviaion 0}

- Keeps records of its actions in sufficient detail to permit auditing;

- Is composed of members having the capability for multidisciplinary roviews with in depth technical competence in areas roviewed;

- Treats safety considerations in sufficient breadth and depth to provide rensonable assurance that all potential consequence in areas being reviewed;

- Provides for group discussion on all but more routine matters; and

- Provides an independent determination of whether a proposed experimental activity involves an unreviewed safety question or other matters."

\section{SITE REQUIREMENT SOURCE: DOE/EH0135 FR.1.3}

"3. The SRC is responsible to assure that an independent safety review has been made of all experiments including designs, operational parameters conduct of experiments, and expected impact on the site. "

\section{SITE REQUIREMENT SOURCE: DOE/EH0135 FR.3.1}

"*1. The quality of each review is evident from the documentation of the scope and content of the review. Documentation of each review includes identification of significant safety questions that were considered, and the basis for judging why each was considered to be either acceptable or unacceptable."

\section{SITE REQUIREMENT SOURCE: DOE5480.5 Section 8.h}

"For new nuclear facilities and for significant modifications to existing nuclear facilities, review of safety analyses design criteria, environmental assessments and environmental impact statements, and other design documents to assure adequate ES\&H consideration."

\section{SITE REQUIREMENT SOURCE: DOE5480.5 Section 9.a}

"Functions primarily in an advisory capacity to the line organization, reporting to a designated official at a level of management sufficiently high to take any necessary corrective action. (Safety is a line responsibility; neither review nor subsequent approval releases line management from its responsibility for the safety of people and equipment.)"

\section{SITE REQUIREMENT SOURCE: DOE5480.5 Section 9.d}

"Provides technical competence in the areas being reviewed. Each review, except that described in subparagraph $9 \mathrm{i}$, below, shall be carried out by persons whose technical disciplines cover the range of technical fields encountered in performing a safety review. Safety considerations are to be treated in the breadth and depth necessary to identify potential hazards and to evaluate the risks." 


\section{REQUIREMENTS IDENTIFICATION DOCUMENT HIGH LEVEL WASTE STORAGE TANK FARMS Nuclear Safety \\ Reviaion 0}

\section{SITE REQUTREMENT SOURCE: DOE5480.5 Section 9.e}

"Provides for group discussions between reviewers on all but the more routine matters."

\section{SITE REQUIREMENT SOURCE: DOE5480.5 Section 9.f}

"Provides an independent determination of whether a proposed activity involves an unreviewed safety questions, violation of a Criticality Safety Limit, Operational Safety Requirement, or any matter for which approval is required."

\section{SITE REQUIREMENT SOURCE: DOE5480.5 Section 9.h(1)-(11)}

"Provides for objective and independent reviow of:

(1) Proposed modifications to nuclear facilities and equipment having safety significance, and safety analyses thereof.

(2) Proposed experiments and operations having safety significance.

(3) Administrative, operating (normal and abnormal), maintenance, repair, testing, quality assurance, and emergency procedures and significant changes thereto.

(4) Organization and staffing.

(5) Standards, Nuclear Criticality Safety Limits, Operational Safety Requirements, and changes thereto.

(6) Nuclear facility safety training programs, including the initial and subsequent qualification and verification requirements and procedures for criticality safety.

(7) Unusual occurrences, including those referred to as incidents, operating anomalies, and violations of Nuclear Criticality Safety Limits or Operational Safety Requirements.

(8) The physical condition of the nuclear facilities.

(9) The accuracy and completeness of record keeping and documentation.

(10) Facility operations against its safety analyses.

(11) Facility operational compliance with the requirements of this Order."

\section{Qperations Review Committee}

An internal Operations Review Committee (ORC) should be formed for each facility to ensure the safe operation, maintenance, and modification of that facility or its associated processes. The role of the ORC should be clearly defined and documented in a charter. The ORC should be independent of the organizations being reviewed or appraised, and it should advise line management of safety issues. Controls should be developed to measure 


\section{REQUIREMENTS IDENTIFICATION DOCUMENT \\ HIGH LEVEL WASTE STORAGE TANK FARMS \\ Nuclear Safety \\ Reriaion 0}

and audit performance of the ORC. Members of the ORC abould have varied expertise and backgrounds to ensure tochnical competence in each roviow area.

\section{STTE REQUIREMENT SOURCE: DOE/EH0135 FR.1}

\section{"FR.1 SAFETY REVIEW COMMITTEE}

PERFORMANCE OBJECTIVE: A Safety Roviow Committeo should be available to roviow safety questions and the safety impacts of experiments. This committes is part of the "Contractor Independent Review and Appraisal System" specified in DOE 5480.5, or DOE 5480.6, and/or DOE 5482.1B., Section 9.d."

\section{SITE REQUIREMENT SOURCE: DOE/EH0135 FR.1.1}

"*1. The Safety Review Committoe (SRC):

- Is appointed by management;

- Functions in an advisory capacity to management;

- Has a written charter which specifies its responsibility, authority, composition, quorum, documentation of efforts, and reporting requirements;

- Keeps records of its actions in sufficient detail to permit auditing;

- Is composed of members having the capability for multidisciplinary reviews with in depth technical competence in areas reviewed;

- Treats safety considerations in sufficient breadth and depth to provide reasonable assurance that all potential consequence in areas being reviewed;

- Provides for group discussion on all but more routine matters; and

- Provides an independent determination of whether a proposed experimental activity involves an unreviewed safety question or other matters."

\section{SITE REQUIREMENT SOURCE: DOE/EH0135 FR.1.2}

"Management ensures that suitable technical people are made available to the SRC as requested to provide specialty services as needed for safety review. "

\section{SITE REQUIREMENT SOURCE: DOE/EH0135 FR.1.3}

"3. The SRC is responsible to assure that an independent safety reviow has been mado of all experiments including designs, operational parameters conduct of experiments, and expected impact on the site." 


\section{REQUIREMENTS IDENTIFICATION DOCUMENT \\ FIGH LEVEL WASTE STORAGE TANK FARMS \\ Nuclear Safety \\ Reviaion 0}

\section{SITE REQUTREMENT SOURCE: DOE/EH0135 FR.2}

\section{"FR.2 SAFETY REVIEW TOPICS}

PERFORMANCE OBJECTIVE: Item that require reviow by the Safety Roviow Committee should be well defined and understood by facility management."

\section{SITE REQUTREMENT SOURCE: DOR5480.5 Section 8.8}

"Basic Requiremeats. The environment, safoty, and health program for nuclear facilitice shall include the following:

Notification, investigation, and reporting of occurrences and utilization of a follow up system to assure remedial action has been implemented."

\section{SITE REQUIREMENT SOURCE: DOES480.5 Section 8.1}

"Basic Requirements. The environment, safety, and health program for nuclear facilities shall include the following:

i. For now nuclear facilities and for significant modifications to existing nuclear facilities, reviews and inspections during construction, acceptance of systems, and preoperational phases to assure compliance with the appropriate ES\&H standards and requirements."

SITE REQUIREMENT SOURCE: DOE5480.5 Section 9, Opening Statement

"Each contractor to whom this Order is made applicablo shall establish and maintain an internal safety review system for nuclear facilities" "

\section{SITE REQUIREMENT SOURCE: DOE5480.5 Section 9.a}

"Functions primarily in an advisory capacity to the line organization, reporting to a designated official at a level of management sufficiently high to take any necessary corrective action. (Safety is a line responsibility; neither reviow nor subsequent approval releases line management from its responsibility for the safety of people and equipment.)"

\section{SITE REQUIREMENT SOURCE: DOE5480.5 Section 9.b}

"Is clearly defined and delineated in writing (e.8., purposes, objectives, functions, authority, responsibility, composition, quorum, meeting frequency, and reporting requirements).

Be clearly defined in writing."

SITE REQUIREMENT SOURCE: DOE5480.5 Section 9.c

"CONTRACTOR INDEPENDENT REVIEW AND APPRAISAL SYSTEM. Each contractor to whom this Order is made applicable shall establish and maintain an internal safety review system for nuclear facilities which: 


\section{REQUIREMENTS IDENTIFICATION DOCUMENT \\ FIGH LEVEL WASTE STORAGE TANK FARMS \\ Nuclear Safety \\ Reviaion 0}

c. Can be audited by contractor managemeat and by DOE. The performence of the syatem shall be recorded in sufficieat detail to permit contractor managemeat and DOE to evaluate its effectivenoss. Actions tsken on eny recommendations reculting from reviewa, audits, inspection, apprials, and surveillences shall bo included in these records."

\section{SITE REQUTREMENT SOURCE: DOES480.5 Section 9.d}

"Provides technical competence in the areas being reviewed. Ench review, except that described in subpangraph 9i, below, shall be carried out by persons whose technical disciplines cover the nenge of technical fields encountered in performing a safoty reviow. Safoty considerations are to be treated in the breadth and dopth neceacary to identify potential hezards and to evaluato the risks."

\section{STIE REQUTREMENT SOURCE: DOE5480.5 Section 9.e}

"Provides for group discussions between reviewers on all but the more routine matters."

\section{SITE REQUTREMENT SOURCE: DOE5480.5 Section 9.f}

"Provides an independent determination of whether a proposed activity involves an unreviewed safety questions, violation of a Criticality Safety Limit, Operational Safety Requirement, or any matter for which approval is required."

\section{SITE REQUIREMENT SOURCE: DOE5480.5 Section 9.8}

"Provides an appraisal of the overall operation of each facility at least annually. The majority of the individuals performing the appraisal shall be independent of the operation being appraised. It shall include, but not be limited to, applicable areas listed in subparagraph $9 \mathrm{~h}^{\text {" }}$

\section{SITE REQUIREMENT SOURCE: DOF5480.5 Section 9.h(1)-(11)}

"Provides for objective and independent roview of:

(1) Proposed modifications to nuclear facilities and equipment having safety significance, and safety analyses thereof.

(2) Proposed experiments and operations having safety significance.

(3) Administrative, operating (normal and abnormal), maintenance, repair, lesting, quality assurance, and emergency procedures and significant changes thereto.

(4) Organization and staffing.

(5) Standards, Nuclear Criticality Safety Limits, Operational Safety Requirements, and changes thereto. 


\section{REQUIREMENTS IDENTIFICATION DOCUMENT \\ FIGH LEVEL WASTE STORAGE TANK FARMS \\ Nuclear Safety \\ Reriaion 0}

(6) Nuclear facility affety training programe, including the initial and subsequeat qualification and verification requirements and procedures for criticality eafety.

(7) Unural occurrences, including those referred to as incidents, operating anomalies, and violations of Nuclear Criticality Safety Limits or Operational Safoty Requirementu.

(8) The physical condition of the nuclear facilitien.

(9) The accuracy and completenese of record keeping and documentation.

(10) Facility operations against its safety analyses.

(11) Facility operational compliance with the requirements of this Order."

\section{STIE REQUIREMENT SOURCE: DOES480.5 Section 9.i}

"Criticality safety program shall be reviewed by management for adequacy of performance every 3 years, or more often, as required.

Review the overall operation of each facility with sufficient frequency to assure adequate ES\&H coverage."

\section{Safety Oversight Committee}

At the site level, a Safety Oversight Committee (SOC) should be formed to perform routine appraisals of the overall safety of facility operations. The SOC should advise senior management, and it should be independeat of the organizations being reviowed or appraised. The role of the SOC should be clearly defined and documented in a charter. Controls should be developed to measure and audit performance of the SOC. Members of the SOC should have varied expertise and backgrounds to ensure technical competence in each review area.

\section{SITE REQUIREMENT SOURCE: DOE/EH0135 FR.2}

\section{"FR.2 SAFETY REVIEW TOPICS}

PERFORMANCE OBJECTIVE: Items that require review by the Safety Reviow Committce should be well defined and understood by facility management."

\section{SITE REQUTREMENT SOURCE: DOE/EH0135 FR.2.1}

1. The Safety Review Committee is involved with reviowing:

*. Incidents and accidents involving significent safety problems and selected Unusual Occurrence Reports (UORs).

- All facility, process, equipment or instrumentation modifications, and any other changes to safety-related systems or components. 


\section{REQUTREMENTS IDENTIFICATION DOCUMENT \\ FIGH LEVEL WASTE STORAGE TANK FARMS Nuclear Safety \\ Reviaion 0}

- Changea to, and violations of, Technical Specificationa/Operational Safoty Requirements.

*. Proposed experimeatal programs.

*- Any other problem that facility or contractor management foels may have safoty significance.

- The quality verification activities related to designs, design changes, fabrication, installation, and chockout of equipment and instrumentation.

- All accident analyses performed of facility activities or systems on the site.

- The effects of facility aging.

- All facility restart plans/operational safety roviows.

\section{SITE REQUIREMENT SOURCE: DOE/EH0135 FR.3.1}

"*1. The quality of each review is evident from the documentation of the scope and content of the review. Documentation of each reviow includes identification of significant safety questions that were considered, and the basis for judging why each was considered to be either acceptable or unacceptable."

\section{SITE REQUIREMENT SOURCE: DOE/EH0135 FR.3.2}

"2. Each facility manager promptly reports to the Safety Review Committee (SRC) any topic which may be of concern."

\section{SITE REQUIREMENT SOURCE: DOE/EH0135 FR.3.3}

3. After review, recommendations of the SRC are submitted to top contractor management."

\section{SITE REQUIREMENT SOURCE: DOE/EHO135 FR.3.4}

4. Recommendations of the SRC are approved or disapproved by top management, and those approved are sent to the facility manager for implementation."

\section{SITE REQUIREMENT SOURCE: DOE/EH0135 FR.3.5}

"5. The reasons for management rejection of any SRC recommendation are documented."

\section{SITE REQUIREMENT SOURCE: DOE/EH0135 FR.3.6}

"6. All but-the most routine matters are dealt with through group discussions with participation by appropriate disciplines. " 


\section{REQUIREMENTS IDENTIFICATION DOCUMENT \\ HIGH LEVEL WASTE STORAGE TANK FARMS \\ Nuclear Safety \\ Reviaion 0}

\section{STTE REQUTREMENT SOURCE: DOES480.5 Section 9, Opening Statement}

"Each contractor to whom this Order is mado applicable shall cotablish and mantain an internal safety reviow system for nuclear facilities" "

\section{STIE REQUIREMENT SOURCE: DOE5480.5 Section 9.a}

"Functions primarily in an advisory capacity to the line organization, reporting to a designated official at a lovel of management sufficiently high to take any necesesary corrective action. (Safety is a line responsibility; neither review nor subeequeat approval releases line management from its responsibility for the safety of people and equipment.)"

\section{STTE REQUTREMENT SOURCE: DOE5480.5 Section 9.b}

"Is clearly defined and delineated in writing (e.8., purposes, objectives, functions, authority, responsibility, composition, quorum, meeting frequency, and reporting requirements).

Be clearly defined in writing."

\section{SITE REQUIREMENT SOURCE: DOE5480.5 Section 9.C}

"CONTRACTOR INDEPENDENT REVIEW AND APPRAISAL SYSTEM. Each contractor to whom this Order is made applicable shall establish and maintain an internal safety review system for auclear facilities which:

c. Can be audited by contractor management and by DOE. The performance of the system shall be recorded in sufficient detail to permit contractor management and DOE to evaluate its effectiveness. Actions taken on any recommendations resulting from reviews, audits, inspections, appraisals, and surveillance shall be included in these records."

\section{SITE REQUIREMENT SOURCE: DOE5480.5 Section 9.d}

"Provides technical competence in the areas being reviewed. Each review, except that described in subparagraph $9 \mathrm{i}$, below, shall be carried out by persons whose technical disciplines cover the range of tochnical fields encountered in performing a safety review. Safety considerations are to be treated in the breadth and depth necessary to identify potential hazards and to evaluate the risks."

\section{SITE REQUIREMENT SOURCE: DOE5480.5 Section 9.e}

"Provides for group discussions between reviewers on all but the more routine matters."

\section{SITE REQUIREMENT SOURCE: DOE5480.5 Section 9.h(1)-(11)}

"Provides for objective and independent ceview of: 


\section{REQUIREMENTS IDENTIFICATION DOCUMENT \\ HIGH LEVEL WASTE STORAGE TANK FARMS Nuclear Safety \\ Reviaion 0}

(1) Proposed modifications to nuclear facilities and equipment having safety significance, and safety analyses thereof.

(2) Proposed experiments and operations having safety significance.

(3) Administrative, operating (normal and abnormal), maintenance, repair, testing, quality assurance, and emergency procedures and significant changes thereto.

(4) Organization and staffing.

(5) Standards, Nuclear Criticality Safety Limits, Operational Safety Requirements, and changes thereto.

(6) Nuclear facility safety training programs, including the initial and subsequent qualification and verification requirements and procedures for criticality safety.

(7) Unusual occurrences, including those referred to as incidents, operating anomalies, and violations of Nuclear Criticality Safety Limits or Operational Safety Requirements.

(8) The physical condition of the nuclear facilities.

(9) The accuracy and completeness of record keeping and documentation.

(10) Facility operations against its safety analyses.

(11) Facility operational compliance with the requirements of this Order."

\section{SAFETY ANALYSIS}

A documented safety analysis process should be developed to:

a. Provide systematic identification of hazards;

b. Describe and analyze the adequacy of measures taken to eliminate, control, or mitigate identified hazards; and

c. Analyze and evaluate potential accidents, including natural phenomena, and their associated risks.

Once the safety analysis has been performed and documented, then a review of the adequacy and correctness should be performed as discussed in Section 16.3.1.

\section{FACILITY REQUIREMENT SOURCE: DOE-SEN-35-91 Section 3}

\section{"SAFETY GOALS}

DOE has adopted two quantitative safety goals to limit the risks of fatalities associated with its nuclear operations. These goals are the same as those 


\section{REQUIREMENTS IDENTIFICATION DOCUMENT HIGH LEVEL WASTE STORAGE TANK FARMS Nuclear Safety \\ Reviaion 0}

established for nuclear powerplants by the Nuclear Regulatory Commission (NRC) and, like the NRC goals, should be viewed as aiming points for performance. The goals are:

The risk to an average individual in the vicinity of a DOE nuclear facility for prompt fatalities that might result from accidents should not exceed one-tenth of one percent (0.1\%) of the sum of prompt fatalities resulting from other accidents to which members of the population are generally exposed. For evaluation purposes, individuals are assumed to be located within one mile of the site boundary.

The risk to the population in the area of a DOE nuclear facility for cancer fatalities that might result from operations should not exceed one-tenth of one percent $(0.1 \%)$ of the sum of all cancer fatality risks resulting from all other causes. For evaluation purposes, individuals are assumed to be located within 10 miles of the site boundary.

In striving to reach these goals, DOE nuclear facilities and activities shall be designed, constructed, operated, and decommissioned with: a) appropriate barriers to prevent or minimize potential radioactive releases; b) engineered safety features to minimize potential releases; and c) procedural controls to mitigate the effects of potential releases. These goals shall be addressed for both new and existing facilities. Proposed modifications to existing facilities to achieve these goals shall be prioritized along with other proposed modifications based on their safety significance. DOE shall pursue the evolution of additional potential safety goals for plant and co-located workers to support enhanced safe operations of its facilities.

DOE recognizes there are large uncertainties in the data and available methods for assessing risk levels especially with' respect to potential health effects from nuclear facility operations. Therefore, reasonable analyses based on available data using standardized approaches may be employed while more rigorous approaches and better data are developed.

DOE safety goals are aiming points and are not substitutes for compliance with DOE directives and nuclear safety-related rules.

The adoption of safety goals should not be construed as a requirement to conduct probabilistic risk assessments. "

\section{SITE REQUIREMENT SOURCE: DOE-STD-1027-92 Section 2}

\section{"SAR UPGRADE PLAN AND SCHEDULE}

Order 5480.23 requires that a plan and schedule for SAR upgrades be submitted to each PSO. The requirement includes the following elements, for which guidance is provided. 


\title{
REQUIREMENTS IDENTIFICATION DOCUMENT \\ HIGH LEVEL WASTE STORAGE TANK FARMS \\ Nuclear Safety \\ Reriaion 0
}

\subsection{Preliminary Assessment of Facility Hazard}

The preliminary assessment of hazards at a DOE nuclear facility requires only a minimal effort to identify the inventory of hazardous material in order to perform an initial hazard categorization as directed by paragraph 4.f.(10).(d) of the attachment to DOE Order 5480.23 and discussed in Section 3 and Attachment 1 of this Standard. Reviewing basic facility information on intended facility operations and using estimates of material quantities should lead to an acceptable assessment. Whenever questions concerning appropriate facility categorization arise, provide a margin of error by selecting the higher hazard category. This step results in the categorization 2.2 Basis for Content, Schedule and Level of Detail proposed. This Standard gives additional information on the accident analysis techniquee and the level of detail needed as allowed in the graded approach for the analysis techniques and level of detail which should be included in the SAR."

\section{SITE REQUIREMENT SOURCE: DOE5480.23 Section 8}

"Requirements - A contractor, as designated in writing by the PSO, who is responsible for the design, construction, or operation of DOE nuclear facilities shall be required to perform a safety analysis that develops and evaluates the adequacy of the safety basis for each such facility. The safety basis to be analyzed shall include management, design, construction, operation, and engineering characteristics necessary to protect the public, workers, and the environment from the safety and health hazards posed by the nuclear facility or non-facility nuclear operations. All contractors shall be held responsible for adhering to assumptions and commitments set forth in the safety analysis. Contractors shall be required to prepare, and shall submit to DOE for its approval, SARs documenting safety analyses for each DOE nuclear facility under their cognizance. Contractors responsible for conducting one or more non-facility nuclear operations are required to maintain up to date analyses of the safety of such operations and analyses documented in a form that is auditable by DOE. Attachment I provides guidance in greater detail than the requirements of this Order."

\section{Graded Approach}

The NS Program at each site should develop criteria detailing their particular graded approach to safety analysis for their nuclear and non-nuclear facilities, processes, etc. An approval process should be defined such that DOE has the final approval. The level of safety analysis and documentation should be commensurate with:

a. The magnitude of the hazards being addressed,

b. The relative importance of the subject matter to the assurance of safety considering the complexity of the facility, and

c. The stage or stages of the facility life cycle.

Hazards routinely encountered and accepted in the course of everyday life by the vast majority of the general public need not be analyzed in detail.

SITE REQUIREMENT SOURCE: DOE-STD-1027-92 Section 4

\author{
"GRADED APPROACH - ANALYSIS TECHNIQUES
}




\section{REQUIREMENTS IDENTIFICATION DOCUMENT HIGH LEVEL WASTE STORAGE TANK FARMS Nuclear Safety Reviaion 0}

Order 5480.23 states that a graded approach is to be used in the preparation of SARs for nuclear facilities.

\section{Graded Approach Objective}

The objective of a graded approach is to proportion SAR requirements for analysis, evaluation, and documentation to the potential hazards associated with operating DOE nuclear facilities. The level of understanding and control of hazards to workers, the public, and the environment will be comparable for all facilities. For relatively simple facilities, an acceptable level of understanding and control of hazards can be achieved with less sophisticated techniques and less detailed knowledge of facility characteristics than those required for more complex facilities.

The anticipated effect of applying the graded approach is that competing resources will be used more efficiently and produce maximum benefit. As a result, SARs for complex, higher-hazard facilities would be expected to use more resources in meeting the requirements than SARs for simple, lower-hazard facilities. The expectation of the greater expenditure or resources for SARs for complicated, higher-bazard facilities is not meant to imply a lower level of safety or attentiveness is acceptable for simple, lower-hazard facilities. Regardless of hazard and complexity of a facility, adequate safety analysis, evaluation, and supporting documentation must be provided.

The graded approach should be used to eliminate unproductive or unnecessary features or activities which add to the cost of implementation, narrow the envelope to permissible operation, or make the facility management unnecessary ponderous or burdensome. It does not believe the contractor or the responsible manager or PSO form the obligation to maintain and operate the facility safely and efficiently. Requirements which conflict with this responsibility should be brought to the attention of the appropriate DOE management.

This document provides the guidelines for the graded approach to development of the analysis techniques which should be used in the SAR. This is the first step the graded approach for safety analysis of DOE facilities. The analysis techniques described below are useful in the Hazard Analysis Section and the Accident Analysis Section of the SAR. These sections discussed the analysis expected for various types of facilities.

The primary objective of the graded approach the accident analysis is to select and apply a rigorous analysis techniques which provides sufficient detail to assess each postulated accident or failure, the resulting consequences, and all means of prevention or mitigation. The choice of the technique should be defensible and produce meaningful results.

In general, a graded approach dictates a more rigorous and more thoroughly documented analysis and evaluation and higher-hazard facilities than lowerhazard facilities, given the potential for more widespread and severe consequences if a higher-hazard facility fails to meet its safety basis requirements. In all cases, however, the SAR must provide adequate safety 


\section{REQUIREMENTS IDENTIFICATION DOCUMENT HIGH LEVEL WASTE STORAGE TANK FARMS Nuclear Safety \\ Reviaion 0}

analysis, evaluation, and supporting documentation. The Order provides direction on how the graded approach is to be applied to the SAR. The level of effort, sophistication of analysis, and the thoroughness of documentation are to be graded or proportioned commensurate with the considerations listed below:

(1) The magnitude of the hazards being addressed

(2) The complexity of both the facility and/or the safety systems relied on to maintain an acceptable level of risk

(3) The stage or stages of the facility life cycle"

\section{SITE REQUIREMENT SOURCE: DOE5480.23 Section 8.a}

"Graded Approach for the Level of Analysis

(1) Justification for the level of analyses and documentation for each hazard considered shall be provided as part of the plan and schedule submitted in accordance with paragraph 9 (b)(2) of this Order. The level of analysis and documentation for each facility must be commensurate with:

(a) The magnitude of the hazards being addressed;

(b) The complexity of the facility and/or systems being relied on to maintain an acceptable level of risk; and

(c) The stage or stages of the facility life cycle for which DOE approval is sought.

(2) This application of the graded approach is specific for the SAR."

\section{Safety Analysis Report Process}

The Safety Analysis Report (SAR) documents the safety analysis performed for a facility to demonstrate the safety of its design and generation. Procedures should be developed to detail the Safety Analysis Report (SAR) development, update, review, and approval process. Specifically, a safety analysis should provide a formal, documented system giving reasonable assurance that facilities can be operated in a manner that limits risks to the facility personnel and general public and adequately protects property and the environment. The SAR should identify and demonstrate conformance with applicable guides, codes, and standards; identify, evaluate, and document deviations from current design criteria; and describe the bases for controls that eliminate, confine, and mitigcte the consequences of hazards. SARs should document the actual design and operations of a facility or process and thereby demonstrate conformance with assumptions made in the safety analyses, Environmental Impact Statement (EIS), and Environmental Assessment (EA). The analyses should document and account for deviations.

The following topics should be addressed in the SARs in appropriate detail:

a. Definition of the safety basis, demonstration of adherence to the safety basis, and justification of its adequacy;

b. Documentation of the assumptions employed in the safety analysis;

c. Results of the safety analysis that identifies the dominant contributors to 


\section{REQUIREMENTS IDENTIFICATION DOCUMENT \\ HIGH LEVEL WASTE STORAGE TANK FARMS \\ Nuclear Safety \\ Reriaion 0}

the risk of the facility;

d. Emergency planning requirements that result from the safety analysis for a particular facility or process;

e. The bases for the Conduct of Operations program for a facility;

f. The facility Quality Assurance program and how it enhances facility and process safety; and

g. Conceptual plans, including the appropriate safety analyses, for the decontamination and ultimate decommissioning of the facility.

Safety analyses should be initiated during the earliest phases of the facility life cycle. A two-stage analysis is appropriate for conuplex or expensive facilities. First, a Preliminary Safety Analysis Report (PSAR) should 'se completed prior to the start of substantial construction. The PSAR should defin's the final commitments governing preliminary design, procurement, construction, and preoperational testing of a facility including any preliminary commitments to its ultimate design and operation.

Second, a Final Safety Analysis Report (FSAR) should be completed prior to initial operation of the facility. The FSAR should be a risk management tool that defines the final basis for safety and risk acceptance for the facility or operation. FSAR's should include the operating envelope defined in the Technical Safety Requirements (TSRs), safety design bases, commitments to applicable codes and standards, facility management controls, and institutional and human factors safety provisions.

An independent peer review of the SAR should be performed, and upon completion c? the $S A R$, a review should be conducted by independent qualified individuals and line management of the affected organizations prior to submittal of the SAR to DOE for approval.

Programmatic controls should also be developed for the routine review and update, if required, of SARs. During the review process when hazards are identified which can be eliminated, controlled, or mitigated through reasonable measures, appropriate SAR updates should be initiated.

\section{SITE REQUTREMENT SOURCE: DOE-STD-1027-92 Section 1}

"Guidance

SAR NUCLEAR FACILITY GUIDANCE FOR DOE ORDER 5480.23

Order 5480.3 defines the "level of concern" within the framework of Hazard Categorization, which requires the preparation of a SAR for DOE nuclear facilities. Section 3 and Attachment 1 of this Standard provide consistent guidance on facility categorization. All facilities classified as at least Category 3 in accordance with this guidance are required to comply with DOE Order 5480.23. Facilities that do not meet or exceed Category 3 threshold criteria but still possess some amount of radioactive material may be considered Radiological Facilities.

Radiological Facilities are exempt from this Order, but they are not exempt from other safety requirements. DOE Order 5481.1B Identifies requirements for facilities that 


\section{REQUIREMENTS IDENTIFICATION DOCUMENT HIGH LEVEL WASTE STORAGE TANK FARMS Nuclear Safety \\ Reviaion 0}

possess significant non-radiological hazards that may not be covered by DOE Order 5480.23, and DOE Order 5480.11 applies for all facilities including those that are exempt from DOE Order 5480.23. Exemption from the requirements of 5480.23 does not excuse contractors from doing analysis, where applicable, to evaluate potential significant radiation exposures to workers. For example, EM is preparing a limited standard to provide additional and more specific guidance regarding measures necessary to ensure safety for EM Facilities and activities below category 3 criteria. Hazardous chemicals in facilities are governed by DOE Orders 5480.4, 5480.10, 5481.1B and 5483.1A, and accelerators are covered by DOE Order 5480.25 ."

\section{SITE REQUIREMENT SOURCE: DOE5480.23 Section 8}

"Requirements - A contractor, as designated in writing by the PSO, who is responsible for the design, construction, or operation of DOE nuclear facilities shall be required to perform a safety analysis that develops and evaluates the adequacy of the safety basis for each such facility. The safety basis to be analyzed shall include management, design, construction, operation, and engineering characteristics necessary to protect the public, workers, and the environment from the safety and health hazards posed by the nuclear facility or non-facility nuclear operations. All contractors shall be held responsible for adhering to assumptions and commitments set forth in the safety analysis. Contractors shall be required to prepare, and shall submit to DOE for its approval, SARs documenting safety analyses for each DOE nuclear facility under their cognizance. Contractors responsible for conducting one or more non-facility nuclear operations are required to maintain up to date analyses of the safety of such operations and analyses documented in a form that is auditable by DOE. Attachment I provides guidance in greater detail than the requirements of this Order."

\section{SITE REQUIREMENT SOURCE: DOE5480.23 Section 8.a}

"Graded Approach for the Level of Analysis

(1) Justification for the level of analyses and documentation for each hazard considered shall be provided as part of the plan and schedule submitted in accordance with paragraph $9(b)(2)$ of this Order. The level of analysis and documentation for each facility must be commensurate with:

(a) The magnitude of the hazards being addressed;

(b) The complexity of the facility and/or systems being relied on to maintain an acceptable level of risk; and

(c) The stage or stages of the facility life cycle for which DOE approval is sought.

(2) This application of the graded approach is specific for the SAR."

\section{SITE REQUIREMENT SOURCE: DOE5480.23 Section 8.b}

"Scope and Content of Safety Analysis Reports.

(1) SARs shall define the safety basis, document the logic of its derivation, demonstrate adherence to the safety basis, and justify its adequacy.

(2) Each SAR required by this Order shall include thorough documentation of the assumptions employed in the safety analysis." 


\section{REQUTREMENTS IDENTIFICATION DOCUMENT HIGH LEVEL WASTE STORAGE TANK FARMS Nuclear Safety \\ Reviaion 0}

SITE REQUIREMENT SOURCE: DOES480.23 Section 8.b(3)

"A SAR shall include the results of the safety analysis that identifies the dominant contributors to the risk of the facility so that these vulnerabilities can bo better managed. The safety analysis report shall address the following topics:

(a) Executive summary;

(b) Applicable statutes, rules, regulations and Departmental Orders;

(c) Site characteristics;

(d) Facility description and operation, including design of principal structures, components, all systems, engineered safety features, and processes;

(e) Hazard analysis and classification of the facility;

(f) Principal health and safety criteria;

(g) Radioactivo and hazardous material wasto management;

(h) Inadvertent criticality protection;

(i) Radiation protection;

(j) Hazardous material protection;

(k) Analysis of normal, abnormal, and accident conditions, including design basis accidents; assessment of risks; consideration of natural and manmade external events; assessment of contributory and casual ovents, mechanisms, and phenomena; and evaluation of the need for an analysis of beyond-design-basis accidents; however, the SAR is to exclude acts of sabotage and other malevolent acts since these actions are covered under security protection of the facility.

(l) Management, organization, and institutional safety provisions;

(m) Procedures and training;

(n) Human factors;

(o) Initial testing, in-service surveillance, and maintenance;

(p) Derivation of TSRs;

(q) Operational Safety;

(r) Quality assurance;

(s) Emergency preparedness;"

\section{SITE REQUIREMENT SOURCE: DOE5480.23 Section 8.c(1)}

"Hazard Classification for Nuclear Facilities and Operations. Contractors shall be required to perform a hazard analysis of their nuclear activities and classify their processes, operations, or activities in accordance with the following requirements:

(1) Classification Categories. The consequences of unmitigated releases of radioactive and/or hazardous material shall be evaluated and classified by the following hazard categories:

(a) Category 1 Hazard. The hazard analysis shows the potential for significant offsite consequences.

(b) Category 2 Hazard. The hazard analysis shows the potential for significant onsite consequences.

(c) Category 3 Hazard. The hazard analysis shows the potential for only significant localized consequences." 


\section{REQUIREMENTS IDENTIFICATION DOCUMENT \\ HIGH LEVEL WASTE STORAGE TANK FARMS \\ Nuclear Safety \\ Reriaion 0}

SITE REQUIREMENT SOURCE: DOE5480.23 Section 8.c(2)

"Inventory of Hazardous Materials. The hazard analyais shall be based on an inventory eaveloping all radioactive and non-radioactive hezardous materials that are stored, utilized, or may be formed within a nuclear facility."

\section{SITE REQUTREMENT SOURCE: DOES480.23 Section 8.c(3)}

"Evaluation of Potential Releases. The hazard analyais shall identify energy sources or processes that might contribute to the generation or uncontrolled release of hezardous materials. The hazard analysis aball estimato the consequences of accidents in which the facility or process and/or materials in the inventory are assumod to interact, react, or be released in a manner to produce a threat or challenge to the bealth and safety of individuals onsite and offsite."

\section{SITE REQUIREMENT SOURCE: DOE5480.23 Section 8.c(4)}

"Submission of Hazard Analysis to DOE. The hazard analysis sball be submitted to DOE for approval in accordance with the safety analysis plan and schedule required by paragraph $9(\mathrm{~b})(2)$ of this Order."

\section{SITE REQUIREMENT SOURCE: DOE5480.23 Section 8.d}

"Document Control. Contractors with the primary responsibility for the design, construction, operation, or decommissioning of DOE nuclear facilities must maintain such document control as may be necessary to ensure that all users of SARs and their supporting documentation designated by DOE or the contractor as authorized users, including DOE line management and the Department's safety oversight groups, have current editions."

\section{SITE REQUIREMENT SOURCE: DOE5480.23 Section 9.a(1)}

"Implementation Requirements.

a. Approval of Safety Analysis Reports for New DOE Nuclear Facilities.

(1) Contractors shall be required to obtain PSO approval of Preliminary Safety Analysis Reports (PSARs) prior to undertaking procurement of materials and components, construction, and preoperational testing of DOE nuclear facilities. DOE may authorize, in writing, limited activities of this type without approval of a PSAR. PSARs shall document the adequacy of the safety basis for a new nuclear facility and provide assurance that

the facility can be constructed, operated, maintained, and shut down safely and in compliance with applicable laws and regulations."

\section{SITE REQUIREMENT SOURCE: DOE5480.23 Section 9.a(2)}

"Contractors shall be required to submit Final Safety Analysis Reports (FSARs) to the PSO for approval and authorization to operate DOE nuclear facilities. FSARs shall documenc the adequacy of the safety basis and provide assurance 


\section{REQUIREMENTS IDENTIFICATION DOCUMENT HIGH LEVEL WASTE STORAGE TANK FARMS Nuclear Safety \\ Reviaion 0}

that the facility can bo operated, maintained, and shut down afely and in compliance with applicable laws and regulations."

\section{STTE REQUIREMENT SOURCE: DOES480.23 Section 9.a(3)}

"The PSO may direct, in writing, that the PSAR and FSAR for a facility be merged into a single FSAR that moets the requirements of paragraphs $9 a(1)$ and 9a(2) of this paragraph. Tho PSO may also direct, in writing, that a SAR be submitted in stages."

\section{SITE REQUREMENT SOURCE: DOE5480.23 Section 9.b(1)}

"Proparation and Submittal of Upgraded Safety Analysis Reports for Existing Nuclear Facilities.

(1) Contractors responsible for the operation of DOE-owned nuclear facilities that are scheduled to submit a Safety Analysis Report within 12 months after the date of issuance of this Order, shall implement a program to upgrade, as necessary, the safety analyses to reflect the requirements of this Order. The upgraded safety analysis shall provide assurance that the facility can be operated, maintained, and shut down safely and be in compliance with applicable laws and regulations. Upgraded SARs shall be submitted to the PSO for approval in accordance with the plan and schedule required by paragraph 9(b)(2) of this Order."

\section{SITE REQUIREMENT SOURCE: DOE5480.23 Section 9.b(2)}

" Plan and Schedule for Safety Analysis Reports. Each contractor responsible for submitting a SAR shall be required to submit to the PSO, for its review and approval, an overall plan and schedule for completing this effort. For existing facilities or operations, the plan and schedule shall be submitted to the Department for approval by 6 months after the date of issuance of this Order. This submittal shall describe the need for upgrading the SAR and shall include a preliminary assessment of facility hazards, the basis for the content, schedule, and level of detail proposed, bases for interim operation or restrictions on interim operations, and administrative controls during the upgrade process. Once submitted plan and schedule is approved by DOE, the contractor shall comply with the plan and schedule, including any DOE modifications. The plan and schedule submitted by a contractor shall be considered approved 150 days after submittal, including any modifications made or directed by DOE during or after this period, unless it is approved by DOE at an earlier date. Approved plans and schedules may be changed, but such changes must be approved in the same manner as initial plans and schedules."

\section{SITE REQUIREMENT SOURCE: DOE5480.23 Section 9.c}

"Periodic Updates of Safety Analysis Reports. Contractors shall be required to review and update as necessary, SARs annually, pursuant to this Order to ensure that the information in each SAR is current and remains applicable. Revisions shall be submitted to the PSO at least annually and shall reflect all changes implemented up to 6 months prior to the filing of the updated SAR. The DOE approval of any Unreviewed Safety Question pursuant to DOE 5480.21, amendments to the TSRs, and the material submitted by the contractor to the PSO in support of these approvals shall be considered an addendum to the SAR until the information is incorporated into the SAR as part of the next annual update." 


\section{REQUIREMENTS IDENTIFICATION DOCUMENT HIGH LEVEL WASTE STORAGE TANK FARMS Nuclear Safety Reriaion 0}

\section{FACIITY REQUREMENT SOURCE: DOE6430.1A Section 0110-5.2}

"Architectural and Special Deaign Requirements - Safety Analyais. All DOE facilities aball be evaluated for potential risks to operatore, the public, and the environment. DOE 5481.1B contains criteria for determining the level of reporting required besed on facility functions and potential accident risks. Safety analyais report timing, content, and format criteria and approval provisions are contained in DOE 5481.1B. This ecction contains a brief summery of the basic requirements of 5481.1B."

\section{FACILITY REQUTREMENT SOURCE: DOE6430.1A Section 0110-5.2[3]}

"The Final Safety Analysis Report (FSAR) stall be doveloped during the construction phase of the project and shall be completed and approved prior to the initiation of facility operations. The FSAR shall be updated as appropriate to reflect changes affecting safety that are made to the facility during its lifetime."

\section{FACIITY REQUIREMENT SOURCE: DOE6430.1A Section 0110-5.2[4]}

"Areas to be addressed in the safety analysis include, but are not necessarily limited to, the following:

- Form, type, and amount of hazardous materials (nuclear or other) to be stored, handled, or processed

- Principal hazards and risks that can be encountered in facility operation, including potential accidents and predicted consequences of fire, explosion, radiation, toxic exposure, structural failure, wind, flood, earthquake, tornado, operating error, failure of essential operating equipment, and failure of safety systems

- Selected design basis accidents such as DBF, DBW, DBE, DBT, DBA, and DBFL. These shall be postulated and quantified, including the rationale for selection

- Principal design, construction, and operating features selected for preventing accidents or reducing risks to acceptable levels, including the safety margins used"

\section{Hazard Classification}

NS Program controls should be developed to ensure that the hazard class for nuclear facilities are defined in accordance with existing regulations. The NS Program should also ensure that criteria are developed for non-nuclear hazards such as chemical exposures, high pressure equipment, high noise areas, confined spaces, etc., as defined by the Occupational Safety and Health Functional Area. Hazards include radioactive and non-radioactive materials. Programmatic controls should be developed for documenting, reviewing, and approving hazard assessments.

\section{SITE REQUIREMENT SOURCE: DOE-STD-1027-92 Section 3}

\section{"HAZARD CATEGORIZATION}

This section contains a uniform methodology to develop the initial Hazard Categorization specified in the preliminary assessment of the facility hazards in paragraph 9.b.(2) of Order 5480.23 and the final Hazard Categorization specified in paragraph 8.b.(3)(e). The 


\section{REQUIREMENTS IDENTIFICATION DOCUMENT \\ HIGH LEVEL WASTE STORAGE TANK FARMS \\ Nuclear Safety \\ Revision 0}

mothod should enable facility managen and PSOs to determino quickly the likely facility calegorization callod for in paragraph 8.c. An discuesed in the Order, Hasard Categorization is used as only one consideration in the graded approach concept (100 Section 4).

\subsection{Rediological Hezards}

Attachment 1 clasuifies a facility as either Hazard Category 1,2 or 3, depending only on the quantities of radioactive material in the in the facility; and gives the threshold quantities as well as the appropriate groundrules for ovaluating the facility. Only facilitice which fall below the category 3 threabold are exempt from the requirements of DOE Order 5480.23. However, these facilities should have administrative controls in place to ensure minimum are not exceeded through introduction of now material."

\section{SITE REQUTREMENT SOURCE: DOES480.23 Section 8.c(1)}

"Hazard Classification for Nuclear Facilities and Operations. Contractors sball be required to perform a hazard analysis of their nuclear activities and classify their processes, operations, or activities in accordance with the following requirements:

(1) Classification Categories. The consequences of unmitigated releases of radioactive and/or hezardous meterial shall be evaluated and classified by the following hazard categories:

(a) Category 1 Hazard. The hazard analysis shows the potential for significant offsite consequences.

(b) Category 2 Hazard. The hazard analysis shows the potential for significant onsite consequences.

(c) Category 3 Hazard. The hazard analysis shows the potential for only significant localized consequences."

SITE REQUIREMENT SOURCE: DOE5480.23 Section 8.c(2)

"Inventory of Hazardous Materials. The hazard analysis shall bo based on an inventory enveloping all radioactive and non-radioactive hazardous materials that are stored, utilized, or may be formed within a nuclear facility."

\section{SITE REQUIREMENT SOURCE: DOE5480.23 Section 8.c(3)}

"Evaluation of Potential Releases. The hazard analysis shall identify energy sources or processes that might contribute to the generation or uncontrolled release of hazardous materials. The hazard analysis shall estimate the consequences of accidents in which the facility or process and/or materials in the inventory are assumed to interact, react, or be released in a manner to produce a threat or challenge to the health and safety of individuals onsite and offsite." 


\section{REQUTREMENTS IDENTIFICATION DOCUMENT HIGH LEVEL WASTE STORAGE TANK FARMS Nuclear Safety \\ Reviaion 0}

STTE REQUTREMINNT SOURCE: DOE5480.23 Section 8.c(4)

"Submiscion of Hesard Analysis to DOE. Tho bazard analysis shall be submitted to DOE for approval in accordance with the anfety analysis plan and achedule required by paragraph $9(b)(2)$ of this Order."

\section{Qperationalumits}

Analyses ahould be performed to bound, where poscible, all clases of efforts or individual operations within a facility. These analyeses should then be used to establish the bases for imposed limits of operation.

Technical Safety Requirements (TSRs) are those requirements that define the conditions, safo boundaries, and the management or adminiatrative controls necessary to ensure the safe operation of a nuclear facility and to reduce the potential risk to the public and facility workers from uncontrolled releases of radioactive or bezardous materials or from radiation exposures due to inadvertent criticality.

\section{SITE REQUIREMENT SOURCE: DOE5480.22 Section 7}

"POLICY. It is the policy of the Department that nuclear facilities operate within PSO-approved Technical Safety Requirements which prescribe the bounds for safe operation of these facilities in order to protect the bealth and safety of the public and reduce risk to workers."

\section{Procedures To Implement the TSR Process}

The NS Program should develop controls for reviewing procedures that detail the TSR process. General guidelines for a procedure program are presented in the Policies, Plans and Procedures sub-element of the Management Systems Functional Area.

\section{SITE REQUIREMENT SOURCE: DOE5480.22 Section 9.a}

\section{"TECHNICAL SAFETY REQUIREMENTS.}

a. A contractor responsible for the operation of a DOE nuclear facility shall:

(1) prepare Technical Safety Requirements for the facility;

(2) submit the Technical Safety Requirements to the PSO for approval; and

(3) operate the facility in accordance with the Technical Safety Requirements as approved by the PSO including any modification by the PSO;" 


\section{REQUTREMENTS DENTIFICATION DOCUMENT FIGH LEVEL WASTE STORAGE TANK FARMS \\ Nuclear Safety \\ Reviaion 0}

\section{STTE REQUTREMENT SOURCE: DOES480.22 Section 9.C}

"TECHNICAL SAFETY REQUTREMENTS.

c. The TSR and its appendices constitute an agreement or contract between DOE and the facility operating management regarding the safe operation of the facility. As such, they cannot be changed without PSO approval."

\section{SITE REQUTREMENT SOURCE: DOE5480.22 Section 9.f}

\section{"TECHNICAL SAFETY REQUIREMENTS.}

f. The TSR shall be kept current at all times 20 that it reflects the facility as it exists and as it is analyzed in Safety Analysis Reports. Contractors shall determine whether revisions to the Technical Safety Requirements are required upon originating or proposing a revision to a Safety Analysis Report, and, if so, shall prepare revisions and submit them with their basis for PSO approval concurrent with the revisions to the Safety Analysis Report. The TSR must be approved prior to facility or facility practice change. To assure that the TSR is current, it shall be reviewed at least annually along with the facility Safety Analysis Report."

\section{SITE REQUIREMENT SOURCE: DOE5480.22 Section 9.g}

\section{"TECHNICAL SAFETY REQUIREMENTS.}

8. All proposed revisions to Technical Safety Requirements or its Appendices shall be submitted for PSO approval. Such submittals shall include the basis for the proposed revision. Revision implementation shall occur only after PSO approval."

\section{SITE REQUIREMENT SOURCE: DOE5480.22 Section 9.h}

\section{"TECHNICAL SAFETY REQUTREMENTS.}

h. Oaly the current PSO-approved Technical Safety Requirements shall hy used for the operation of the facility. The current PSO-approved Technical Safety Requirements shall be a controlled document."

\section{SITE REQUIREMENT SOURCE: DOE5480.22 Section 9.i}

\section{"TECHNICAL SAFETY REQUIREMENTS.}

i. A contractor may take emergency rctions that depart from the approved Technical Safety Requirements when no actions consistent with the Technical Safety Requirements are immediately apparent, and when these actions are needed to protect the public health and 


\section{REQUIREMENTS IDENTIFICATION DOCUMENT HIGH LEVEL WASTE STORAGE TANK FARMS Nuclear Safety \\ Reviaion 0}

safety. Such contractor actions shall be approved, as a minimum, by a certified operator or supervisor certified on that system through an accredited training program. If emergency actions are taken, verbal notifications shall be made to the Head of the Field Element within 2 hours and by written reports to the PSO within 24 hours."

\section{TSR Document}

A TSR document should contain the following information:

a. Use and Application of TSRs-Definition of terms, operating modes, frequency notation, and actions to be taken in the event of violation of TSR operating limits or surveillance requirements.

b. Safety Limits, Operating Limits, Surveillance Requirements, and Administrative Controls-TSRs should provide all necessary safety limits, operating limits, administrative controls, and surveillance requirements for safe operation of a facility.

\section{SITE REQUIREMENT SOURCE: DOE5480.22 Section 9.b}

\section{"TECHNICAL SAFETY REQUIREMENTS.}

b. Technical Safety Requirements shall define the operating limits and surveillance requirements, the basis thereof, safety boundaries, and management or administrative controls necessary to protect the health and safety of the public and to minimize the potential risk to workers from the uncontrolled release of radioactive or other hazardous materials and from radiation exposure due to inadvertent criticality. Technical Safety Requirements shall be based on the facility Safety Analysis Report and shall set forth specific limits and other requirements as specified in this Order and Attachment 1 to this Order, "Guidelines for Technical Safety Requirements." Attachment 1 presents an approach for the implementation and preparation of Technical Safety Requirements documents which is acceptable to DOE. Other approaches that are compatible with Attachment 1 may be utilized providing that they are justified and approved in writing by the PSO."

\section{SITE REQUIREMENT SOURCE: DOE5480.22 Section 9.d}

\section{"TECHNICAL SAFETY REQUIREMENTS.}

d. TSRs should be written in a clear and concise manner, in language that is directed at and clearly understandable by those in the facility operating organization. The TSR should not contain excessive details that are more appropriate to the Safety Analysis Report." 


\section{REQUIREMENTS IDENTIFICATION DOCUMENT HIGH LEVEL WASTE STORAGE TANK FARMS Nuclear Safety \\ Reviaion 0}

SITE REQUIREMENT SOURCE: DOE5480.22 Section 9.e

"TECHNICAL SAFETY REQUIREMENTS.

e. Technical Safety Requirements shall consist of the following:

(1) Use and Application. Definitions of terms, operating modes, frequency notations, and actions to be taken in the event of violation of Technical Safety Requirements operating limits or surveillance requirements are to be included in the Use and Application section. This section of the Technical Safety Requirements shall contain the basic instructions for using and applying the safety restriction contained in the Technical Safety Requirements.

(2) Safety Limits (SL). Safety Limits are limits on process variables associated with those physical barriers, generally passive, that are necessary for the intended facility function and which are found to be required to guard against the uncontrolled release of radioactivity and other hazardous materials (this includes releases into the complex and/or the community). If any Safety Limit is exceeded at any reactor or nonreactor nuclear facility, action shall begin immediately to place the facility in the most stable, safe condition attainable including total shutdown of either reactor or nonreactor nuclear facilities. The appropriate time frame for the completion of the action for each nuclear facility has to be developed and justified by the contractor, as appropriate, in the TSR document which requires PSO approval. The SLs shall describe the action to be taken when an SL is exceeded. If a SL is exceeded, the contractor shall notify DOE in accordance with DOE 5000.3A, review the matter, and record the results of the review. The review shall include the cause of the condition and the basis for any corrective actions taken to preclude reoccurrence. The safe, stable condition entered as corrective action shall be maintained until the cognizant Program Manager authorizes further operations.

(3) Operating Limits

(a) Limiting Control Settings (LCS). Limiting Control Settings are settings on safety systems that control process variables to prevent exceeding Safety Limits. This subsection of the Technical Safety Requirements shall contain the settings for automatic alarms and automatic or non-automatic initiation of protective actions related to those variables having significant safety functions. The specific settings shall be chosen such that if exceeded, sufficient time is available to automatically or manually correct the condition prior to exceeding Safety Limits. If the automatic alarms or 


\section{REQUIREMENTS IDENTIFICATION DOCUMENT HIGH LEVEL WASTE STORAGE TANK FARMS Nuclear Safety \\ Reviaion 0}

protective devices do not function as required during applicable operating modes, the contractor shall take action as defined in the Limiting Control Setting to maintain the variables within the requirements and to promptly repair the automatic devices or the affected part of the process or, if required, the facility shall be placed in its most safe, stable condition. The LCS shall describe the action to be taken in case of exceedance of LCS. If an LCS is exceeded, the contractor shall notify DOE in accordance with DOE $5000.3 \mathrm{~A}$, review the matter, and record the results of the review including the cause of the condition and the basis for any corrective actions taken to preclude reoccurrence.

(b) Limiting Conditions for Operation (LCO). Limiting Conditions for Operation are the lowest functional capability or performance level of safety-related structures, systems, component and their support systems required for normal safe operation of the facility. This subsection of the TSR shall contain the limits on functional capability or performance level. When a Limiting Condition for Operation is not met, the contractor shall take remedial actions defined by the Technical Safety Requirements until the condition can be met. The LCO shall describe the action to be taken in case of exceedance of the LCO. In cases of exceedance of an LCO, the contractor shall notify DOE in accordance with DOE 5000.3A, review the matter, and record the results of the review including the cause of the condition and the basis for any corrective actions taken to preclude reoccurrence.

(4) Surveillance Requirements. Surveillance Requirements are requirements relating to test, calibration, or inspection to ensure that the necessary operability and quality of safety-related structures, systems, components, and their support systems required for safe operation of the facility are maintained. This section of the Technical Safety Requirements shall contain the requirements necessary to maintain operation of the facility within the Safety Limits, Limiting Control Settings, and Limiting Conditions for Operations. In the event that Surveillance Requirements are not successfully completed or accomplished within their required frequency, the systems or components involved shall be assumed to be inoperative and actions defined by the Limiting Condition for Operation or Limiting Control Setting shall be taken until the systems or components can be shown to be operable.

(5) Administrative Controls. Administrative Controls are the provisions relating to organization and management, procedures, record keeping, reviews, and audits necessary to 


\section{REQUIREMENTS IDENTIFICATION DOCUMENT HIGH LEVEL WASTE STORAGE TANK FARMS Nuclear Safety \\ Reviaion 0}

ensure safe operation of the facility. This section of the Technical Safety Requirements shall contain the requirements associated with Administrative Controls including those for reporting deviations from Technical Safety Requirements (i.e., exceedances of LCO, LCS, or SR, or violation of TSR). Staffing requirements for facility position important to safe operation of the facility shall be provided in the Administrative Controls sections. Physical and administrative controls of the criticality safety program shall also be provided in the Administration Controls section.

(6) Appendices. The following information shall be in the Appendices:

(a) Basis. This Appendix shall provide summary statements of the reasons for the operating limits and associated surveillance requirements. The basis shall show how the numeric value, the condition, or the surveillance does fulfill the purpose derived from the safety documentation. The primary purpose for describing the basis for each requirement will not affect its original intent or purpose.

(b) Design Features. This Appendix shall describe passive design features of the facility which, if altered or modified, would have a significant effect on safe operation. If Design Features are in a DOE-approved Safety Analysis Report, this Appendix is not required."

\section{Review and Approval of a TSR Document}

Measures should be established to ensure that the TSR for a facility is kept current and that it reflects the facility as it exists and as it is analyzed in SARs. A formal review and approval process for TSRs should be established to ensure anproval of each TSR prior to facility or procedure modification. The review process should require routine review of each TSR for a facility in comparison to the facility SAR.

\section{SITE REQUIREMENT SOURCE: DOE5480.22 Section 9.f}

"TECHNIC.AL SAFETY REQUIREMENTS.

f. The TSR shall be kept current at all times so that it reflects the facility as it exists and as it is analyzed in Safety Analysis Reports. Contractors shall determine whether revisions to the Technical Safety Requirements are required upon originating or proposing a revision to a Sefety Analysis Report, and, if so, shall prepare revisions and submit them with their basis for PSO approval concurrent with the revisions to the Safety Analysis Report. The TSR must be approved prior to facility or facility practice change. To assure that the TSR is current, it shall be 


\section{REQUIREMENTS IDENTIFICATION DOCUMENT HIGH LEVEL WASTE STORAGE TANK FARMS \\ Nuclear Safety \\ Reviaion 0}

reviewed at least annually along with the facility Safety Analysis

Report."

\section{SITE REQUIREMENT SOURCE: DOE5480.22 Section 9.g}

\section{"TECHNICAL SAFETY REQUIREMENTS.}

g. All proposed revisions to Technical Safety Requirements or its Appendices shall be submitted for PSO approval. Such submittals shall include the basis for the proposed revision. Revision implementation shall occur only after PSO approval."

\section{SITE REQUIREMENT SOURCE: DOE5480.22 Section 9.h}

\section{"TECHNICAL SAFETY REQUIREMENTS.}

b. Only the current PSO-approved Technical Safety Requirements shall be used for the operation of the facility. The current PSO-approved Technical Safety Requirements shall be a controlled document."

\section{UNREVIEWED SAFETY QUESTIONS}

When a potential inadequacy is discovered in the facility technical basis, safety analysis, operational requirements, TSRs, or margin of safety, a Unreviewed Safety Question (USO) determination should be performed to determine its safety significance. Moreover, a safety evaluation may be required for changes to nonsafety-related systems if the potential exists to affect the proper operation of safety systems, structures, or components. Criteria establishing the basis for a USQ should be developed and incorporated in the overall NS Program. A USQ situation exists if:

a. The probability of occurrence or the consequences of an accident or malfunction of equipment important to safety previously evaluated in the facility safety analyses could be increased;

b. The possibility for an accident or malfunction of a different type than any evaluated previously in the facility safety analyses could be created; or

c. Any margin of safety, as defined in the bases of the TSRs, could be reduced.

To ensure protection of the public health and safety of the workers and the public from the risks of hazardous and radioactive materials, the USQ review process should be integrated into the technical review process associated with the following Functional Areas: Engineering Design, Maintenance, Operations, Research and Development and Experimental Activities, and Management Systems (i.e., the Compliance Management element). 


\section{REQUIREMENTS IDENTIFICATION DOCUMENT HIGH LEVEL WASTE STORAGE TANK FARMS Nuclear Safety \\ Reviaion 0}

\section{SITE REQUIREMENT SOURCE: DOE5480.21 Section 8.a}

"POLICY. It is the Department's policy that:

a. Each facility develop procedures to implement the Unreviewed Safety Question review process consistent with the provisions described in this Order."

\section{SITE REQUTREMENT SOURCE: DOE5480.21 Section 8.b}

"POLICY. It is the Department's policy that:

b. Any changes made to a facility that directly or indirectly affect the facility authorization basis, and therefore its safety, be reviewed in accordance with the provisions of this Order."

\section{SITE REQUIREMENT SOURCE: DOE5480.21 Section 8.c}

"POLICY. It is the Department's policy that:

c. Primary responsibility, authority, and accountability for the direction and management of the USQ process reside with the line management of the facility organization responsible for the design and safety analyses."

\section{Development of USO Training and Controls}

The NS Program should include the following USQ programmatic controls:

a. A training program for all personnel responsible for performing USQ reviews including the staff associated with the Engineering Design, Maintenance, Operations, Management Systems, (i.e., Compliance Management), Research and Development and Experimental Activities, and NS Functional Areas.

b. Procedures detailing the USQ process for technical reviews including modification reviews to be performed on a nuclear facility or activity.

\section{SITE REQUIREMENT SOURCE: DOE5480.21 Chapter III, Section 1.b}

"First, each facility must identify the methods by which facility changes can he made (i.e., are changes made under a modification process, nonconformance processes, maintenance processes, etc.). After these methods have been identified, each facility must determine what constitutes an acceptable means to make a change. That is, the contractor must clearly control the facility change process and must perform and document changes in accordance with approved procedures. Performing a modification under the guise of maintenance is not acceptable because the proper control processes to analyze the proposed change and document its outcome would probably be absent. Identification of all means for performing a change is necessary because each one provides a direct input into the USQ process and must be integrated accordingly." 


\section{REQUIREMENTS IDENTIFICATION DOCUMENT \\ HIGH LEVEL WASTE STORAGE TANK FARMS \\ Nuclear Safety \\ Reviaion 0}

SITE REQUTREMENT SOURCE: DOE5480.21 Chapter III, Section 2

"Once the contractor organization has determined the various sources of change, it must then determine the process by which these sources of change should be integrated into the USQ review process."

\section{SITE REQUIREMENT SOURCE: DOE5480.21 Chapter II, Section 5.a}

"Implementing Procedures.

a. Contractors are required to develop procedures that provide detailed guidance for the performance and review of USQ determinations. At a minimum, the procedures shall define the purpose of the procedure; set forth the procedure's applicability; provide definitions of appropriate terms, including those set forth in this Order; include screening criteria, as appropriate, and the basis for their application; include detailed guidance on what must be considered and evaluated when performing or reviewing a safety evaluation; define the qualifications needed and responsibilities of personnel performing and reviewing safety evaluations; and include documentation requirements for each USQ determination."

\section{SITE REQUIREMENT SOURCE: DOE5480.21 Chapter III, Section 5.b}

"Implementing Procedures.

b. The purpose of the procedure should reflect the purpose of the Order and its implementation as defined herein. The applicability of the procedure should set forth the facility(s) to which it applies and the types of change processes to which it applies (e.g., use-as-is nonconformances, corrective actions for violations, procedural changes, and facility changes). If desired, the contractor may elect to develop separate implementing procedures for procedural changes versus facility and administrative changes. If this option is selected, each procedure should provide enough guidance to permit its independent use."

\section{SITE REQUIREMENT SOURCE: DOE5480.21 Chapter III, Section 5.c}

"Implementing Procedures.

c. Contractors are expected to provide detailed guidance and instructions on how to perform a safety evaluation. This guidance should include, at a minimum, the information provided in Chapter IV of this guidance document, refined to include the specifics of the applicable facility. Instructions and a worksheet similar to that provided in Attachment I to this Order are recommended. Again, this information should be adapted to each facility's specific circumstances and needs." 


\section{REQUIREMENTS IDENTIFICATION DOCUMENT HIGH LEVEL WASTE STORAGE TANK FARMS Nuclear Safety \\ Reviaion o}

SITE REQUIREMENT SOURCE: DOE5480.21 Chapter III, Section 5.d

"Implementing Procedures.

d. The implementing procedures should address the personnel qualifications needed in order to perform or review a safety evaluation. This includes required educational background, years and/or types of work experience, knowledge of the facility, understanding of DOE requirements, and familiarity with the facility authorization basis. Specific responsibilities of those performing or reviewing safety evaluations should be clearly defined."

\section{SITE REQUIREMENT SOURCE: DOE5480.21 Chapter II, Section 5.e}

"Implementing Procedures.

e. Documentation requirements should also be discussed in the USQ implementing procedures. They should identify the level of detail necessary to document performance of the safety evaluation and conclusions reached; a list of references relied upon to reach this conclusion as well as guidance for the retention of records should also be included. Other items cited for inclusion in the implementing procedures are self-explanatory."

\section{SITE REQUIREMENT SOURCE: DOE5480.21 Chapter III, Section 8}

"All personnel responsible for performing, reviewing, or approving USQ determinations should receive initial training on the application of the Order and of facility-specific procedures. Retraining is recommended on an interval of every 2 years or as may be proposed by the contractor."

\section{SITE REQUIREMENT SOURCE: DOE5480.21 Chapter II, Section 9.a}

"Implementation Schedule. Because the concepts set forth in this Order are not new to DOE and its contractors, but merely clarify and consolidate requirements previously implemented within the DOE Order system, compliance with this Order is expected immediately upon its promulgation. However, since DOE understands that the manner and rigor with which this Order is implemented departs somewhat from previous interpretations of these requirements, implementation of a program in the manner described herein shall be established based on the schedule set forth below.

a. Development of USQ Governing Procedures. The manner in which changes are made at a facility and the formal integration and documentation of these change processes with the requirements of this Order should be completed within 9 months of the promulgation of this Order." 


\section{REQUIREMENTS IDENTIFICATION DOCUMENT HIGH LEVEL WASTE STORAGE TANK FARMS Nuclear Safety \\ Reviaion 0}

\section{SITE REQUIREMENT SOURCE: DOE5480.21 Chapter III, Section 9.c}

"Implementation Schedule. Because the concepts set forth in this Order are not new to DOE and its contractors, but merely clarify and consolidate requirements previously implemented within the DOE Order system, compliance with this Order is expected immediately upon its promulgation. However, since DOE understands that the manner and rigor with which this Order is implemented departs somewhat from previous interpretations of these requirements, implementation of a program in the manner described herein shall be established based on the schedule set forth below.

c. Implementation of Initial Training. Initial training should be completed within 1 year of the promulgation of this Order."

\section{SITE REQUIREMENT SOURCE: DOE5480.21 Section 10.a}

\section{"PROGRAM REQUIREMENTS.}

a. A contractor authorized to operate DOE nuclear facilities shall:

(1) Perform all safety evaluations required by paragraph (b) of this section to determine whether a situation involves USQ;

(2) Prior to implementation of a proposed action, obtain PSO approval for situations determined to involve a USQ or a Technical Safety Requirements (TSR) change; and

(3) Develop and implement procedures to govern the need for, and the performance of, safety evaluations under this section."

SITE REQUIREMENT SOURCE: DOE5480.21 Section 8.a

"POLICY. It is the Department's policy that:

a. Each facility develop procedures to implement the Unreviewed Safety Question review process consistent with the provisions described in this Order."

\section{SITE REQUIREMENT SOURCE: DOE5480.21 Section 8.b}

"POLICY. It is the Department's policy that:

b. Any changes made to a facility that directly or indirectly affect the facility authorization basis, and therefore its safety, be reviewed in accordance with the provisions of this Order."

\section{SITE REQUIREMENT SOURCE: DOE5480.21 Section 8.c}

"POLICY. It is the Department's policy that:

c. Primary responsibility, authority, and accountability for the direction and management of the USQ process reside with the line 


\section{REQUIREMENTS IDENTIFICATION DOCUMENT HIGH LEVEL WASTE STORAGE TANK FARMS Nuclear Safety \\ Reviaion 0}

management of the facility organization responsible for the design and safety analyses."

\section{USO Determination}

A safety evaluation process should be established to ensure that a safety evaluation is performed for:

a. Temporary or permanent changes in the facility as described in the existing safety analyses;

b. Temporary or permanent changes in the procedures as described in the existing safety analyses; or

c. Test or experiments not described in the existing safety analyses.

SITE REQUIREMENT SOURCE: DOE5480.21 Chapter III, Section 1.C

"Second, in order to determine what constitutes a USQ, an understanding of what constitutes the facility's authorization basis must be defined; it is this basis that ultimately provides the acceptable bounds of operation without requiring prior DOE approval."

\section{SITE REQUIREMENT SOURCE: DOE5480.21 Chapter II, Section 2}

"Once the contractor organization has determined the various sources of change, it must then determine the process by which these sources of change should be integrated into the USQ review process."

\section{SITE REQUIREMEN I SOURCE: DOE5480.21 Chapter III, Section 3.a}

"The Order consistently refers to the safety analyses. These safety analyses are intended to define those aspects of design and operation, that are important to safety and therefore those aspects that DOE relies upon to allow initial and continued operations. Although ideally all changes made to a facility would be analyzed, documented, and incorporated into the Safety Analysis Report, thus providing a complete authorization basis, such thoroughness has rarely occurred in the past. In addition, often times when facility operations require the completion of different processes (campaigns) the safety analysis supporting individual processes may or may not be incorporated into the Safety Analysis Report."

\section{SITE REQUIREMENT SOURCE: DOE5480.21 Chapter III, Section 3.b}

"When DOE facilities were first authorized to operate, it was not anticipated that the need for facility modifications would be implemented with the frequency that has proven to be necessary. As a result, the need for elaborate configuration and modification controls were not clearly understood. Because of this, many changes have taken place at facilities and the supporting documents and analyses have not always been integrated into a single facility SAR. Hence, the authorization basis of the facility may not 


\section{REQUTREMENTS IDENTIFICATION DOCUMENT HIGH LEVEL WASTE STORAGE TANK FARMS Nuclear Safety \\ Reviaion 0}

be reflected in total in the current facility SAR. For this reason, the language in this Order referring to safety analyses is intended to mean the facility authorization basis. This basis, depending upon the facility, may reside in several different types of documents. These may include not only the facility SAR, but historical commitments made by contractors to support modifications and the imposition of new DOE ryquirements or administrative changes. These may also include DOE saitîy evaluation reports that modify contractor-proposed changes or analyses. The intent of this Order is to preserve the authorization basis, and, if this basis is not reflected in total in the SAR, the contractor must define that population of documents comprising the various elements of the authorization basis and must use this defined population of documents as the basis for performing safety evaluations under the requirements of this Order."

\section{SITE REQUIREMENT SOURCE: DOE5480.21 Chapter III, Section 4.a}

"DOE finds that it is acceptable to use screening criteria to limit the number of proposed actions for which written safety evaluations must be performed, provided the reasons for exclusion are documented and well supported. In fact, DOE encourages the use of screening criteria because, when properly defined and implemented, the screening criteria should assist in reducing the efforts expended for issues of minor significance and should focus efforts more fully on the aspects of safety for which this requirement is intended."

\section{SITE REQUIREMENT SOURCE: DOE5480.21 Chapter III, Section $4 . b$}

"Screening criteria are intended to be applied to those items that, by broad definition, enter into the USQ process but for which a detailed safety evaluation is not necessary. For example, an operational procedure which is described in the SAR may require a change to correct a typographical error or include an additional reference to an equipment list. This change, although by definition within the bounds of this Order, is not of any safety

significance. If the contractor applied a screening procedure that asks: "Is the change inconsequential"? (i.e., a spelling or typographical correction, grammatical change, clarification, or additional note or reference), the reviewer could document the shange and thus avoid the need to answer the detailed questions of the safety evaluation process."

\section{SITE REQUIREMENT SOURCE: DOE5480.21 Chapter III, Section 4.C}

"A different manner in which screening criteria may be applied is through categorical exclusions (e.g., different procedure types). For the purpose of illustration, maintenance procedures may be considered. If it is true that no modifications or changes are performed under maintenance procedures, then a basic premise of performing maintenance is that the plant will be returned to the exact same "condition" it was in prior to maintenance. That is, the functional condition will continue to meet or exceed those performance capabilities set forth in the authorization basis. A change to a maintenance procedure would therefore not be governed under this Order. Other requirements, such as the DOE 4330.4A, may draw some bounds upon the subject and content of these procedures, but this Order need not be considered. 


\section{REQUIREMENTS IDENTIFICATION DOCUMENT HIGH LEVEL WASTE STORAGE TANK FARMS Nuclear Safety \\ Reviaion 0}

However, it should be understood that, by applying ecreening criteria in this manner, DOE would expect to find a detailed evaluation of why, for example, a one-time categorical exclusion of maintenance procedures from the USQ process is acceptable."

\section{SITE REQUIREMENT SOURCE: DOE5480.21 Chapter III, Section 4.d}

"For physical modifications to the facility, DOE does not believe that screening criteria would be appropriate. The application of screening criteria for administrative changes may prove useful, but contractors must ensure that the use of these criteria do not inappropriately screen out changes that require safety ovaluations."

\section{SITE REQUIREMENT SOURCE: DOE5480.21 Chapter III, Section 5.a}

"Implementing Procedures.

a. Contractors are required to develop procedures that provide detailed guidance for the performance and review of USQ determinations. At a minimum, the procedures shall define the purpose of the procedure; set forth the procedure's applicability; provide definitions of appropriate terms, including those set forth in this Order; include screening criteria, as appropriate, and the basis for their application; include detailed guidance on what must be considered and evaluated when performing or reviewing a safety evaluation; define the qualifications needed and responsibilities of personnel performing and reviewing safety evaluations; and include documentation requirements for each USQ determination."

\section{SITE REQUIREMENT SOURCE: DOE5480.21 Chapter III, Section 5.b}

"Implementing Procedures.

b. The purpose of the procedure should reflect the purpose of the Order and its implementation as defined herein. The applicability of the procedure should set forth the facility(s) to which it applies and the types of change processes to which it applies (e.g., use-as-is nonconformances, corrective actions for violations, procedural changes, and facility changes). If desired, the contractor may elect to develop separate implementing procedures for procedural changes versus facility and administrative changes. If this option is selected, each procedure should provide enough guidance to permit its independent use."

SITE REQUIREMENT SOURCE: DOE5480.21 Chapter III, Section 5.c

"Implementing Procedures.

c. Contractors are expected to provide detailed guidance and instructions on how to perform a safety evaluation. This 


\section{REQUIREMENTS IDENTIFICATION DOCUMENT HIGH LEVEL WASTE STORAGE TANK FARMS Nuclear Safety Reviaion 0}

guidance ahould include, at a minimum, the information provided in Chapter IV of this guidance document, refined to include the specifics of the applicable facility. Instructions and a worksheet aimilar to that provided in Attachment I to this Order are recommended. Again, this information should be adapted to each facility's specific circumstances and needs."

\section{SITE REQUIREMENT SOURCE: DOBS480.21 Chapter III, Section 5.d}

"Implementing Procedures.

d. The implementing procedures should address the personnel qualifications needed in order to perform or reviow a safety ovaluation. This includes required educational background, years and/or types of work experience, knowledge of the facility, understanding of DOE requirements, and familiarity with the facility authorization basis. Specific responsibilities of those performing or reviewing safety ovaluations should be clearly defined."

\section{STTE REQUIREMENT SOURCE: DOE5480.21 Chapter III, Section 6.a}

" Safety Evaluations (USQ Determination). Specific guidance on how to conduct a safety evaluation is contained in Attachment I to this Order. The concepts used to develop this process are contained throughout this document. The intent of this section is not to reiterate these points but to explain more clearly the scope of a safety evaluation and thereby clarify its practical uses.

a. A safety evaluation, unlike a safety analysis, is somewhat limited in scope. When reading this Order, it should be noted that the definitions of a USQ are based on consequences and probabilities of accidents. These accidents, their assumed initiators, and their consequences focus on the performance capabilities of systems, structure, and components under presumed conditions. These performance capabilities are related to facility operations and design inasmuch as the design and/or specific operations are relied upon to meet performance requirements set forth in the authorization basis of the systems, structures, and components in question. When reviewing or evaluating a change in this manner, those aspects of design that support the particular performance of systems, structures, and components relevant to the change will bo reviewed, although others may not be."

\section{S TE REQUIREMENT SOURCE: DOE5480.21 Chapter III, Section 6.b}

"Safety Evaluations (USQ Determination). Specific guidance on how to conduct a safety evaluation is contained in Attachment I to this Order. The concepts used to develop this process are contained throughout this document. The intent of this section is not to reiterate these points 


\section{REQUIREMENTS IDENTIFICATION DOCUMENT FIGH LEVEL WASTE STORAGE TANK FARMS Nuclear Safety \\ Reviaion 0}

but to explain more clearly the scope of a safety ovaluation and thereby clarify its practical uses.

b. A contractor may decide to replace an existing gate valve with another valve type. Under this Order, he/she will ovaluato this change to assure that the now valve meets or exceeds its intended performance requirements as set forth in the authorization basis. This evaluation may discuss such issues as closure times, valve leakage, and suitability of the new valve materials for its particular environment. This evaluation may concludo that a USQ will not be created. It may also be true that this new valve contains materials that bave different corrosive properties than the previous valve, which in turn requires different maintonance practices. If properly maintained, this aspect of the design of the now valve may in no way inhibit performance and would therefore bo unlikely to bo considered in the safety evaluation. This aspect of the now valves design should not and will not be overlooked if a proper safety analysis is conducted. When making a change, the safety analysis process requires that all aspects of both design and performance be considered."

\section{SITE REQUIREMENT SOURCE: DOE5480.21 Chapter II, Section 6.c}

" Safety Evaluations (USQ Determination). Specific guidance on how to conduct a safety evaluation is contained in Attachment I to this Order. The concepts used to develop this process are contained throughout this document. The intent of this section is not to reiterate these points but to explain more clearly the scope of a safety evaluation and thereby clarify its practical uses.

c. A safety evaluation is not a substitute for a safety analysis; it merely serves as a benchmark for whether the authorization basis is being preserved. Contrary to the above-cited example, a safety analysis may show that a proposed change is safe, yet the safety evaluation may determine that this change is an Unroviewed Safety Question and hence requires DOE approval prior to implementation. Contractor procedures should clearly establish the differences between the concepts supporting a safety analysis and those used for a safety evaluation. The procedures governing the safety analysis process and the safety evaluation process, although similar in many respects, should be treated separately."

\section{SITE REQUIREMENT SOURCE: DOE5480.21 Chapter III, Section 9.b}

"Implementation Schedule. Because the concepts set forth in this Order are not new to DOE and its contractors, but merely clarify and consolidate requirements previously implemented within the DOE Order system, compliance with this Order is expected immediately upon its promulgation. However, since DOE understands that the manner and rigor with which this Order is implemented departs somewhat from previous interpretations of these requirements, implementation of a program in the manner described herein shall be established based on the schedule set forth below. 

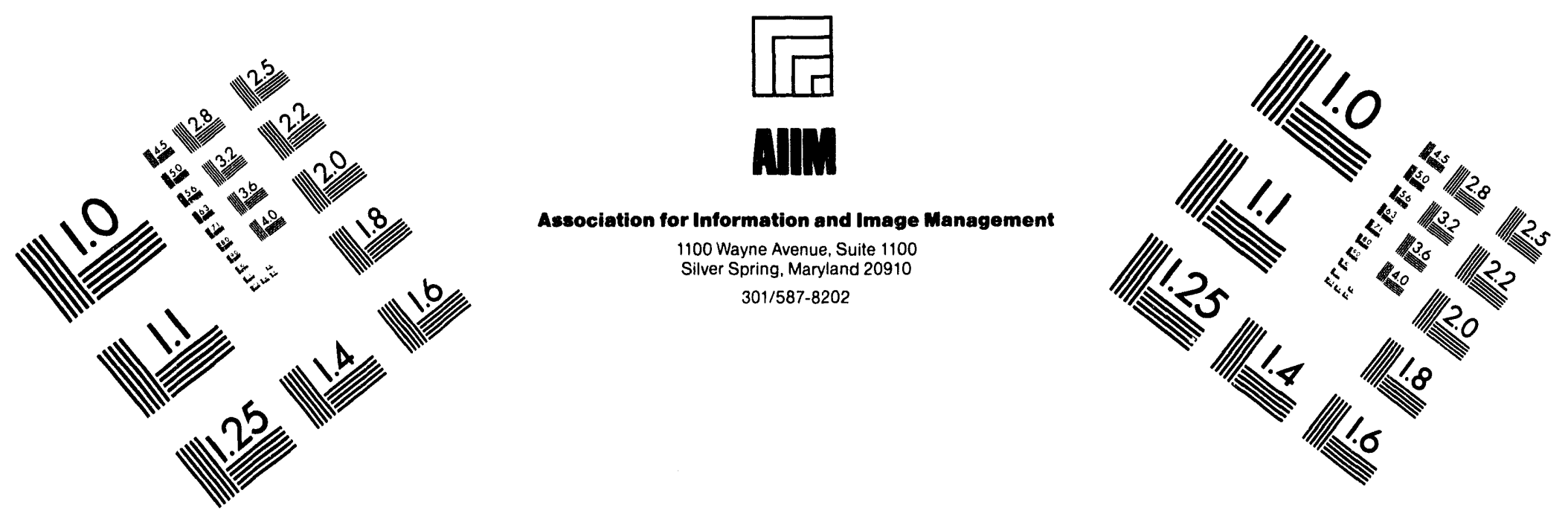

\section{Centimeter}

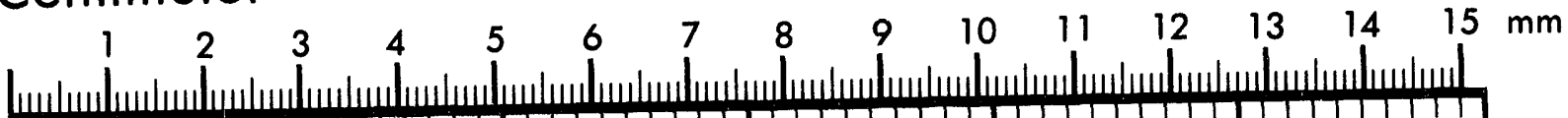

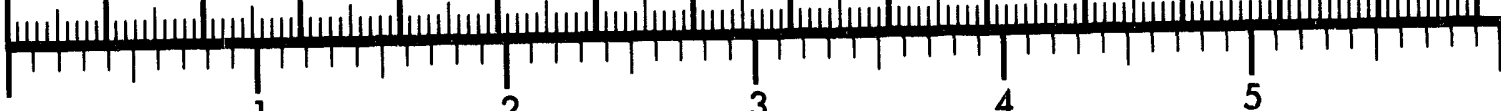
Inches

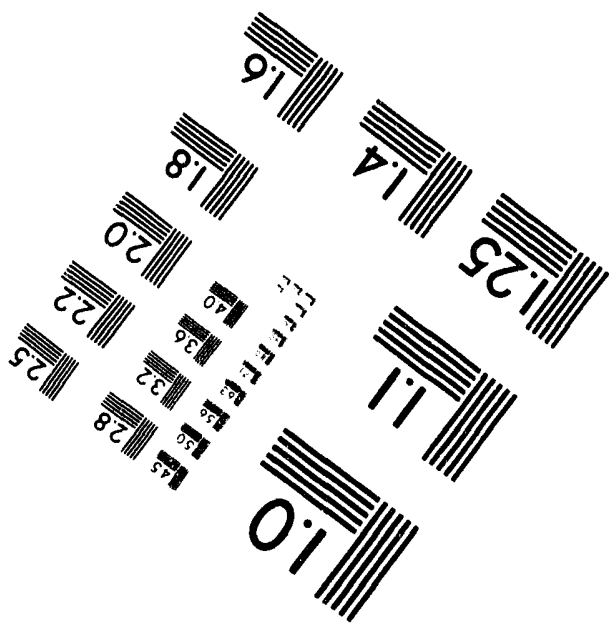

MANUFACTURED TO AIIM STANDARDS BY APPLIED IMAGE. INC.

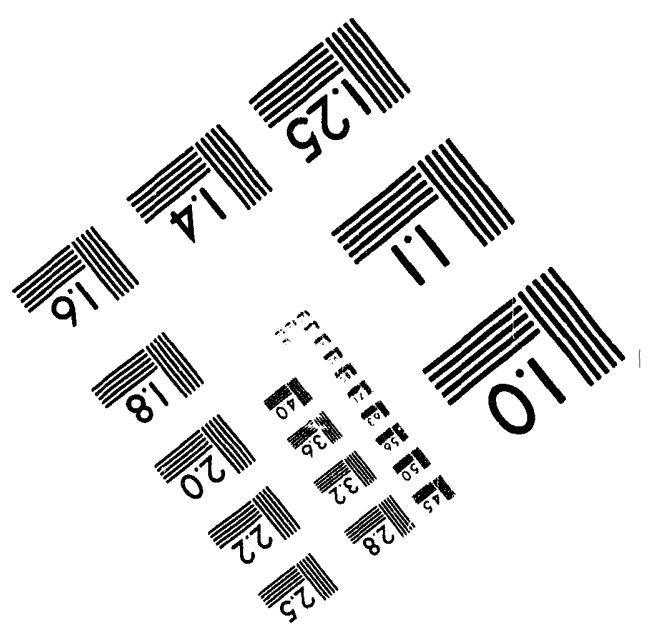



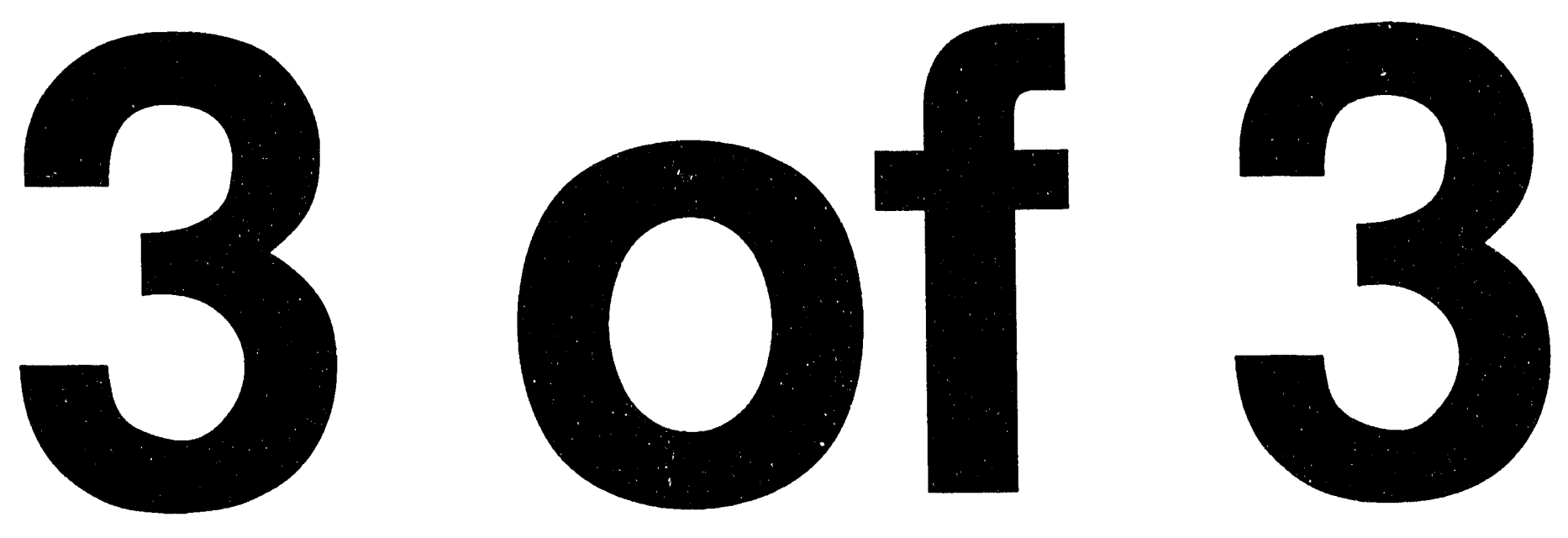


\section{REQUIREMENTS IDENTIFICATION DOCUMENT HIGH LEVEL WASTE STORAGE TANK FARMS Nuclear Safety \\ Reviaion 0}

b. Development of Facility-Specific Safety Evaluation Procedures. These procedures shall be completed within 9 months of the promulgation of this Order."

\section{SITE REQUIREMENT SOURCE: DOE5480.21 Section 10.b}

\section{"PROGRAM REQUIREMENTS.}

b. A safety evaluation shall be performed for:

(1) Temporary or permanent changes in the facility as described in the existing safety analyses;

(2) Temporary or permanent changes in the procedures as described in existing safety analyses; or

(3) Test or experiments not described in existing safety analyses."

\section{SITE REQUIREMENT SOURCE: DOE5480.21 Section 10.c}

"PROGRAM REQUIREMENTS.

c. A situation involves a USQ if:

(1) The probability of occurrence or the consequences of an accident or malfunction of equipment important to safety previously evaluated in the facility safety analyses could be increased;

(2) The possibility for an accident or malfunction of a different type than any evaluated previously in the facility safety analyses could be created; or

(3) Any margin of safety, as defined in the bases of the TSRs, could be reduced."

\section{Notifications, Evaluations, and Actions}

When a potential inadequacy of previous safety analyses or a possible reduction in the margin of safety as defined in the TSRs is identified, the following programmatic sub-elements should be in place.

a. A notification process should be developed to alert DOE and facility management of the potential safety concern.

b. Procedures should be developed to place the facility in a safe condition until a resolution of the safety concern can be determined. A satisfactory resolution of the safety concern could be the reconfiguring of the facility to its previous documented safe condition, or performance of a safety evaluation to justify its existing condition. 


\section{REQUIREMENTS IDENTIFICATION DOCUMENT HIGH LEVEL WASTE STORAGE TANK FARMS \\ Nuclear Safety \\ Reviaion 0}

\section{SITE REQUIREMENT SOURCE: DOE5480.21 Chapter III, Section 7}

"Periodic Reports. At a minimum, all contractors should submit to DOE a report summarizing all "changes" made under this Order. This requirement is noted in paragraph $10 . "$

\section{SITE REQUIREMENT SOURCE: DOE5480.21 Section 10.d}

"PROGRAM REQUIREMENTS.

d. When a contractor identifies information that indicates a potential inadequacy of previous safety analyses or a possible reduction in the margin of safety as defined in the TSRs, the contractor shall:

(1) Notify the PSO of the situation upon discovery of the information;

(2) Make an evaluation in accordance with paragraphs 10a and 10c;

(3) Take action to place the facility in a safe condition until the safety evaluation is completed; and

(4) Submit the completed safety evaluation prior to removing any operational restrictions initiated pursuant to paragraph $\operatorname{lod}(2) . "$

\subsubsection{Documentation}

The general guidelines for a procedure program are addressed in the Policies, Plans and Procedure sub-element of the Management Systems Functional Area. Specific requirements for a USQ documentation process include the following:

a. Procedures/process for performing, documenting, reviewing, and approving a safety evaluation.

b. Procedures for documenting the basis for the USQ determination.

c. Procedures for incorporating any changes that are needed as a result of the safety evaluation into the existing SAR.

d. Procedures for maintaining the documentation associated with the safety evaluation and USQ determination.

\section{SITE REQUIREMENT SOURCE: DOE5480.21 Chapter II, Section 3.c}

"It is expected that, as an initial step toward developing a USQ process, each contractor will define for their facility those aspects and documents that constitute the authorization basis and identify these documents within the facility USQ procedures."

SITE REQUIREMENT SOURCE: DOE5480.21 Chapter III, Section 5.e

"Implementing Procedures. 


\section{REQUIREMENTS IDENTIFICATION DOCUMENT HIGH LEVEL WASTE STORAGE TANK FARMS \\ Nuclear Safety \\ Reviaion 0}

e. Documentation requirements should also be discussed in the USQ implementing procedures. They should identify the level of detail necessary to document performance of the safety evaluation and conclusions reached; a list of references relied upon to reach this conclusion as well as guidance for the retention of records should also be included. Other items cited for inclusion in the implementing procedures are self-explanatory."

\section{SITE REQUIREMENT SOURCE: DOE5480.21 Chapter III, Section 7}

"Periodic Reports. At a minimum, all contractors should submit to DOE a report summarizing all "changes" made under this Order. This requirement is noted in paragraph 10."

\section{SITE REQUIREMENT SOURCE: DOE5480.21 Section 10.e}

\section{"PROGRAM REQUIREMENTS.}

e. For all safety evaluations required under this section, a contractor shall:

(1) Document the basis for the USQ determination, utilizing the procedures provided for in paragraph 10a(3) of this section and the criteria of paragraph 10c;

(2) Maintain documentation required by paragraph $10 \mathrm{e}(1)$ for the authorized operating period of the nuclear facility and ensure the complete transfer of all documentation to any subsequent contractor prior to termination of its contract;

(3) Incorporate in the existing SAR, any changes that are needed as a result of the safety evaluation or any action taken; and

(4) Submit to the PSO, on a schedule corresponding to the periodic updates of the SAR, a report summarizing all situations for which a safety evaluation was required by this section and indicating all "changes" considered in a safety evaluation and implemented 6 months or more before the submittal date of the report."

\section{SITE REQUIREMENT SOURCE: DOE5700.6C Section 9.b(1)(d)}

"Criterion 4 - Documents and Records Documents shall be prepared, reviewed, approved, issued, used, and revised to prescribe processes, specify requirements, or establish design. Records shall be specified, prepared, reviewed, approved, and maintained."

\section{NUCLEAR CRITICALITY SAFETY}

Controls should be developed to ensure that fissionable materials are produced, stored, processed, traisferred, disposed or handled in such a manner that the probability of a 


\section{REQUIREMENTS IDENTIFICATION DOCUMENT \\ HIGH LEVEL WASTE STORAGE TANK FARMS \\ Nuclear Safety \\ Reviaion 0}

criticality accident is acceptably low. All operations involving fissionable material should be conducted under strict and effective nuclear criticality controls at all times. Specific nuclear criticality safety practices that should be developed for Tank Farms beyond those already addressed in the Tank Farms NS Program are addressed in the following sub-elements.

\section{SITE REQUIREMENT SOURCE: DOE/EH0135 CS.1}

\section{"CS.1 ORGANIZATION AND ADMINISTRATION}

PERFORMANCE OBJECTIVE: All operations with fissionable material should be conducted to provide effective nuclear criticality control during all activities."

\section{SITE REQUIREMENT SOURCE: DOE/EH0135 CS.1.1}

"*1. The program meets the requirements of DOE 5480.5 and ANSI/ANS 8.1-1983."

\section{SITE REQUIREMENT SOURCE: DOE/EH0135 CS.1.2}

"*2. The nuclear criticality safety program is defined and documented."

\section{SITE REQUIREMENT SOURCE: DOE/EH0135 CS.1.3}

"*3. There exists a nuclear criticality safety function that is independent of operational responsibilities.

\section{SITE REQUIREMENT SOURCE: DOE/EH0135 CS.1.4}

"*4. The nuclear criticality safety program includes a formal internal review and audit of conformance of operations to the program."

\section{SITE REQUIREMENT SOURCE: DOE/EH0135 CS.3}

\section{"CS.3 NUCLEAR CRITICALITY SAFETY EVALUATIONS}

PERFORMANCE OBJECTIVE: Nuclear criticality safety evaluations of the design and operation of process equipment should ensure that subcriticality is maintained under normal and credible abnormal operating conditions."

\section{SITE REQUIREMENT SOURCE: DOE5480.24 Section 1}

"PURPOSE. To establish nuclear criticality safety program requirements ensuring that:

a. Criticality safety is comprehensively addressed and receives an objective review, with all identifiable risks reduced to acceptably low levels and management authorization of the operation is documented. 


\section{REQUIREMENTS IDENTIFICATION DOCUMENT HIGH LEVEL WASTE STORAGE TANK FARMS Nuclear Safety \\ Reviaion 0}

b. The public, workers, Government property and essential operations are protected from the effects of a criticality incident."

\section{SITE REQUIREMENT SOURCE: DOE5480.24 Section 3}

"POLICY. Fissionable materials shall be produced, processed, stored, transferred, disposed or handled in such a manner that the probability of a criticality incident is acceptably low, and to the extent practical, Government and private personnel and public and private property are protected from damaging effects and undue hazards that may arise from a criticality incident. "

\section{SITE REQUIREMENT SOURCE: DOE5480.24 Section 7.a(1)}

"REQUIREMENTS. The contractor criticality safety program for nuclear facilities shall include the following requirements:

a. The basic elements and control parameters of programs for nuclear criticality safety shall satisfy the requirements of the following mandatory American Nuclear Society's ANSI/ANS nuclear criticality safety standards:

ANS-8.1, "Nuclear Criticality Safety in Operations with Fissionable Materials Outside Reactors," except paragraphs 4.2.2 and 4.2.3.

ANS-8.3, "Criticality Accident Alarm System," except paragraphs 4.2 and 4.2.2.

ANS-8.5, "Use of Borosilicate-Glass Raschig Rings as a Neutron Absorber in Solutions of Fissile Material."

ANS-8.15, "Nuclear Criticality Control of Special Actinide Elements."

ANS-8.19, "Administrative Practices for Nuclear Criticality Safety."

ANS-8.7, "Guide for Nuclear Criticality Safety in the Storage of Fissile Materials."

(1) Contractors shall be required to comply with the requirements ("shall" statements) and the recommendations ("should" statements) of the mandatory ANS nuclear criticality safety standards except as modified below. When the cognizant PSO approves the technical basis for nonadherence of a recommendation in the ANS standards, the recommendation shall not become a requirement of this Order. Conversely, when the cognizant PSO does not approve nonadherence of a recommendation of the ANS standards, that recommendation shall become a requirement under this Order." 


\section{REQUIREMENTS IDENTIFICATION DOCUMENT HIGH LEVEL WASTE STORAGE TANK FARMS Nuclear Safety \\ Reviaion 0}

\section{SITE REQUIREMENT SOURCE: DOE5480.24 Section 7.c}

"Nuclear criticality safety programs shall be fully documented. In addition to the requirements of the ANS standards, contractors shall perform detailed nuclear criticality safety analyses for specific operations, storage arrangements, and the handling and transportation of fissionable materials.

The basis for criticality safety shall be included in the facility SAR. Additionally, the limiting conditions of operation for criticality safety shall be included in the facility TSRs. Values presented in the standards to ensure criticality safety should be used cautiously and should include all adjustments, conditions, and ranges of applicability called for by the mandatory standards in paragraph $7 \mathrm{a}$ of this Order.

The Criticality Safety section of the SAR shall include (or be included by referring to other sections of the SAR) but not be limited to the following:

(1) A description, using appropriate sketches or drawings, of equipment and facilities in which the hazard of criticality exists showing dimensions in sufficient detail to permit evaluation of the information mentioned in subparagraphs $7 c(3)$ through $7 c(6)$ below.

(2) A statement of the chemical and physical form of fissionable material in each step of the process, including isotopic the nature of any material, and the resulting concentrations, densities, and degrees of moderation throughout the steps of the process.

(3) A statement of the maximum quantities of fissionable material at any one time in each step of the process, including a description of the technical practices which are intended to prevent exceeding these maximum quantities.

(4) A description of the methods of collection, handling, and transportation products from each process area or individual operation and evaluation of the nuclear safety of these methods.

(5) An analysis of criticality incident scenarios and their impact on health and safety of the workers and/or public. This analysis will be used to determine the conditions of operation for criticality safety, the design of the CAS as noted in subparagraph (7) below, and the need for audible and/or visual alarms.

(6) A description of the safety control parameters which are intended to prevent criticality resulting from events such as: accumulation of fissionable material in scrap or waste, lathe turnings, crucible slag, pickling solutions, choppings, sumps, filters, etc. Also included shall be the description of the technical practices used to prevent exceeding the safety control parameters.

(7) A description of the installed CAS and emergency procedures, including alarm levels, fail-safe features, response time of devices, and frequency of evacuation drills. Pertinent documents shall show the 


\section{REQUIREMENTS IDENTIFICATION DOCUMENT HIGH LEVEL WASTE STORAGE TANK FARMS Nuclear Safety Reviaion 0}

location of all detectors, their distance to possible sources of criticality, and intervening shielding and audio and visual alarms.

(8) A description of the technical practices and measurement control program (including reliability and operability characteristics) used in determining the quantities of fissionable material (or other materials such as soluble poisons to prevent accidental criticality) present in any location and the uncertainties of the measured values. The measurement control program shall be in accordance with the latest edition of DOE 5700.6C, QUALITY ASSURANCE.

(9) An analysis of the spacing of masses of fissionable material within each process area and separation from fissionable material in adjoining areas."

\section{Design Practices}

Practices should be developed to control nuclear criticality including geometry control, use of neutron absorbers, employment of the double contingency principle, and use of single-parameter and multi-parameter limits for fissionable nuclides as well as establishment of subcritical limits. Measures to validate calculational models and methods compared to experimental data should be established.

All reasonable steps should be taken to mitigate the consequences of a nuclear criticality event. Where the potential for an inadvertent criticality event exists because the risk cannot be totally eliminated, a criticality alarm system should be installed to alert personnel of a criticality event so that their exposure to radiation can be limited. The system should be reliable and dependable. The system should be designed and tested according to standards for safety-related components and systems, which are delineated in the Radiation Protection and Engineering Design Functional Areas. The system should be installed according to requirements set forth in the Construction Functional Area.

\section{SITE REQUTREMENT SOURCE: DOE5480.24 Section 7.a(2)}

"REQUIREMENTS. The contractor criticality salety program for nuclear facilities shall include the following requirements:

a. The basic elements and control parameters of prog ums for nuclear criticality safety shall satisfy the requirements of the following mandatory American Nuclear Society's ANSI/ANS nuclear criticality safety standards:

ANS-8.1, "Nuclear Criticality Safety in Operations with Fissionable Materials Outside Reactors, " except paragraphs 4.2.2 and 4.2.3.

ANS-8.3, "Criticality Accident Alarm System," except paragraphs 4.2 and 4.2.2.

ANS-8.5, "Use of Borosilicate-Glass Raschig Rings as a Neutron Absorber in Solutions of Fissile Material." 


\section{REQUIREMENTS IDENTIFICATION DOCUMENT HIGH LEVEL WASTE STORAGE TANK FARMS Nuclear Safety Reviaion 0}

ANS-8.15, "Nuclear Criticality Control of Special Actinide Elements."

ANS-8.19, "Administrative Practices for Nuclear Criticality Safety."

ANS-8.7, "Guide for Nuclear Criticality Safety in the Storage of Fissile Materials."

(2) For DOE application, the following sections of ANS-8.1, "Nuclear Criticality Safety in Operations with Fissionable Materials Outside Reactors," shall be read as follows:

(a) 4.2.2 Double Contingency Principle. Process designs shall incorporate sufficient factors of safety to require at least two unlikely, independent, and concurrent changes in process conditions before a criticality accident is possible. Protection shall be provided by either (a) the control of two independent process parameters (which is the preferred approach, if practical) or (b) a system of multiple (at least two) controls on a single parameter. In all cases, no single failure shall result in the potential for a criticality accident. The basis for selecting either approach shall be fully documented.

(b) 4.2.3 Geometry Control. As a first priority, reliance shall be placed on equipment design in which dimensions of the contained fissionable material and spacing between equipment are limited via passive engineering controls. Where geometry control is not feasible, the preferred order of controls is other passive engineering controls, active engineering controls, and administrative controls. Feasibility is determined by weighing risk versus practicality/cost. Full advantage may be taken of any nuclear characteristics of the process, materials and equipment. All dimensions, nuclear properties, and other features upon which reliance is placed shall be verified prior to beginning operations, and control shall be exercised to maintain them. The basis for not selecting geometry control shall be fully documented."

\section{SITE REQUIREMENT SOURCE: DOE5480.24 Section 7.b}

"Periodic inspections, in-situ tests, and preventive maintenance shall be performed at designated frequencies to ensure that the alarm systems and components necessary for criticality control are being properly maintained in readiness for use." 


\section{REQUIREMENTS IDENTIFICATION DOCUMENT HIGH LEVEL WASTE STORAGE TANK FARMS Nuclear Safety \\ Reviaion 0}

SITE REQUIREMENT SOURCE: DOE6430.1A Section 1300-4

"Nuclear Criticality Safety.

An assessment of design shall be made as early as practical to determine if the potential for nuclear criticality exists. When such potential exists, the design of nuclear criticality control provisions, including equipment and procedure, shall meet, as a minimum, the requirements of DOE 5480.5 and the ANS 8 series on Nuclear Criticality Safety."

\section{Materials Control}

Measures should be established to control the movement, storage, and traceability of fissionable material within a facility. Requirements for the offsite packaging, transportation, and traceability of fissionable materials, including nuclear criticality coucerns, are addressed in the Packaging and Transportation Functional Areas.

Measures should be established regarding the labeling and posting of storage areas for fissionable material.

Nuclear criticality safety should be achieved by controlling one or more specific parameters of the system within subcritical limits. Measures should be established to control and monitor the spacing, mass, density, and geometry of fissionable material to assure subcriticality under all normal and credible abnormal conditions that could occur during storage. Controls should be established for use of neutron absorbing materials to assure subcritical conditions.

Guidelines to control the access to areas where fissionable material is stored, handled, or processed should be developed and implemented.

\section{SITE REQUIREMENT SOURCE: DOE5480.24 Section 7.d}

"Contractors shall establish a monitoring and surveillance program to prevent accumulations of fissionable materials in, but not limited to, process equipment and storage, pipe, and ventilation systems. If unsafe accumulations are detected, corrective measures shall be taken to prevent criticality hazards. "

\section{FACILITY REQUIREMENT SOURCE: DOE5480.24 Section 7.e(1)}

"e. Transportation and Storage Requirements for Fissionable Material.

(1) The requirements of this Order shall apply to all activities where fissionable material is transferred from one operation to another within a facility and from one on-site location to another."

\section{Emergency Planning}

The general guidelines for the development of an Emergency Plan are addressed in the Emergency Planning and Preparedness Functional Area. Specific guidelines related to radioactive materials and nuclear criticality include establishment of medical treatment facilities to handle victims who are contaminated with radioactive materials. This also 


\section{REQUIREMENTS IDENTIFICATION DOCUMENT \\ HIGH LEVEL WASTE STORAGE TANK FARMS \\ Nuclear Safety \\ Reviaion 0}

requires interface with the Radiation Protection Functional Area regarding dosimetry and radiation detection instrumentation requirements. Also, measures should be established to address potential criticality events that could result from moderator changes during fire fighting. This should include training the staff of the potential hazards in their work area.

\section{SITE REQUTREMENT SOURCE: DOE/EH0135 CS.5}

\section{"CS.5 CRITICALITY ALARM SYSTEM AND EMERGENCY PROCEDURES}

PERFORMANCE OBJECTIVE: All reasonable steps should be taken to mitigate the consequences of a nuclear criticality accident."

\section{SITE REQUIREMENT SOURCE: DOE5480.24 Section 7.b(2)}

"The requirements in ANSI/ANS-8.3 relating to the needs for an alarm system are not applicable to this Order. For the purpose of this Order, Criticality Alarm Systems (CAS) and criticality detection systems shall be required as follows:

(2) In those cases where the mass of fissionable material exceeds the limits established in paragraph 4.2.1 of ANSI/ANS-8.3 and the probability of criticality is greater than 10/-6 per year, (as documented in a DOE approved SAR), but there are no occupied areas in which the expected dose exceeds 12 Rads in free air, a criticality detection system shall be provided where a criticality detection system is defined to be an appropriate criticality accident detection device but without an immediate evacuation alarm. The criticality accident detection system response time should be sufficient to allow for appropriate process-related mitigation and recovery actions. While an immediate evacuation alarm is not required under these circumstances, evacuation shall be implemented (i.e. evacuation notification or delayed alarm) if potential doses to occupational workers could be effectively limited by such actions in accordance with DOE 5480.11."

\section{Procedures}

Procedures should be developed for operations involving fissionable material. Such procedures should be included as an integral part of the facility design, operations, and modification process. The operating procedures should address criticality safety limits in providing effective guidance for all aspects of facility activities. General guidelines for development, review, approval, and control of procedures are addressed in the Policy and Procedure element of the Management Systems Functional Area.

\section{SITE REQUIREMENT SOURCE: DOE/EH0135 CS.1.5}

"*5. A system for the control and traceability of required records is documented." 


\section{REQUIREMENTS IDENTIFICATION DOCUMENT HIGH LEVEL WASTE STORAGE TANK FARMS \\ Nuclear Safety \\ Reriaion 0}

\section{SITE REQUIREMENT SOURCE: DOE/EH0135 CS.3.3}

"*3. The nuclear criticality safety evaluations are documented with sufficient detail and clarity to allow independent review of the results."

\section{RELATED REFERENCES}

\section{ANSI/ANS-8.19-84 Section 8.3}

\section{SITE REQUIREMENT SOURCE: DOE5480.24 Section 7.c}

"Nuclear criticality safety programs shall be fully documented. In addition to the requirements of the ANS standards, contractors shall perform detailed nuclear criticality safety analyses for specific operations, storage arrangements, and the handling and transportation of fissionable materials.

The basis for criticality safety shall be included in the facility SAR. Additionally, the limiting conditions of operation for criticality safety shall be included in the facility TSRs. Values presented in the standards to ensure criticality safety should be used cautiously and should include all adjustments, conditions, and ranges of applicability called for by the mandatory standards in paragraph $7 \mathrm{a}$ of this Order.

The Criticality Safety section of the SAR shall include (or be included by referring to other sections of the SAR) but not be limited to the following:

(1) A description, using appropriate sketches or drawings, of equipment and facilities in which the hazard of criticality exists showing dimensions in sufficient detail to permit evaluation of the information mentioned in subparagraphs $7 c(3)$ through $7 c(6)$ below.

(2) A statement of the chemical and physical form of fissionable material in each step of the process, including isotopic the nature of any material, and the resulting concentrations, densities, and degrees of moderation throughout the steps of the process.

(3) A statement of the maximum quantities of fissionable material at any one time in each step of the process, including a description of the technical practices which are intended to prevent exceeding these maximum quantities.

(4) A description of the methods of collection, handling, and transportation products from each process area or individual operation and evaluation of the nuclear safety of these methods.

(5) An analysis of criticality incident scenarios and their impact on health and safety of the workers and/or public. This analysis will be used to determine the conditions of operation for criticality safety, the design of the CAS as noted in subparagraph (7) below, and the need for audible and/or visual alarms. 


\section{REQUIREMENTS IDENTIFICATION DOCUMENT \\ HIGH LEVEL WASTE STORAGE TANK FAKMS \\ Nuclear Safety \\ Reviaion 0}

(6) A description of the safety control parameters which are intended to prevent criticality resulting from events such as: accumulation of fissionable material in scrap or waste, lathe turnings, crucible slag, pickling solutions, choppings, sumps, filters, etc. Also included shall be the description of the technical practices used to prevent exceeding the safety control parameters.

(7) A description of the installed CAS and emergency procedures, including alarm levels, fail-safe features, response time of devices, and frequency of evacuation drills. Pertinent documents shall show the location of all detectors, their distance to possible sources of criticality, and intervening shielding and audio and visual alarms.

(8) A description of the technical practices and measurement control program (including reliability and operability characteristics) used in determining the quantities of fissionable material (or other materials such as soluble poisons to prevent accidental criticality) present in any location and the uncertainties of the measured values. The measurement control program shall be in accordance with the latest edition of DOE 5700.6C, QUALITY ASSURANCE.

(9) An analysis of the spacing of masses of fissionable material within each process area and separation from fissionable material in adjoining areas."

\section{KEY PROGRAM INTERFACES}

The implementation and administration of a Nuclear Safety Program requires the definition of functional interfaces with other program functional areas. All facility activities are governed by the site wide Nuclear Safety Program. Specific functional areas must implement the programs/requirements developed by Nuclear Safety. The interfaces between NS and other functional areas within the Tank Farms are as follows:

CONFIGURATION MANAGEMENT - Configuration Management uses input from NS on which to base the configuration control program for future modifications.

ENGINEERING - Engineering incorporates NS requirements into design and design modifications. They also develop and update the Safety Analysis Report per NS requirements.

EMERGENCY PREPAREDNESS - NS supplies information to Emergency Preparedness so they can design their programs and plans around this information. If design conditions change NS will notify the EP organization.

MAINTENANCE - NS receives input from Maintenance if systems/equipment do not perform per design and determines if there is a safety impact to these problem areas.

OCCUPATIONAL HEALTH AND SAFETY - OS\&H provides NS information regarding bealth related areas for inclusion in and modification to the SAR. 


\section{REQUIREMENTS IDENTIFICATION DOCUMENT HIGH LEVEL WASTE STORAGE TANK FARMS \\ Nuclear Safety \\ Reviaion 0}

QUALITY ASSURANCE - Quality Assurance develops the QA program that provides the requirements to be applied to activities determined by Nuclear Safety to be important to quality as described in the Nuclear Safety Quality Assurance Plan. Quality Assurance also provides for the performance of audits and surveillances of NS activities plus quality control inspections to be performed by the QA organization.

RADIOLOGICAL PROTECTION - Radiological Protection programs and procedures perform personnel, equipment and environmental monitoring and keep records to show that the facility is operating within the limits prescribed. RP will notify NS of any findings which are in conflict with any portion of the SAR.

TRAINING AND QUALIFICATION - Training and Qualification establishes the procedures and requirements that control the training and/or selection of certain NS management and technical personnel. Training and Qualification develops training curriculum and keeps records for training to be delivered by NS.

FIRE PROTECTION - Fire Protection provides input to the SAR and supplies information to NS if there are changes to any systems or requirenzents described in the SAR.

CONSTRUCTION - Construction supplies reports to NS and Engineering so that any deviations from the design can be compared to the SAR to determine that the as-built plant complies with all aspects of the SAR.

SELF ASSESSMENT - Nuclear Safety interacts with Self Assessment to determine what programs can be developed to give assurance that NS is performing its duties in a safe and effective manner.

ENVIRONMENTAL PROTECTION - Environmental Protection supplies information to NS to show how their periodic monitoring programs confirm that the assumptions of the SAR are working out in practice. If there are any deviations from expected results the two groups will investigate to determine the cause and a course of corrective action.

OCCURRENCE REPORTING - NS provides analysis of occurrence reports to determine root cause, Unreviewed Safety Questions and other types of events which may require management to take corrective action.

SAFEGUARDS AND SECURITY - The Safeguards and Security Functional Area addresses acts of sabotage and other malevolent acts involving special nuclear material (SNM) and nuclear facilities and operations. These should not be addressed in SARs or other publicly available documents to ensure facility security.

OPERATIONS - The Operations Functional Area should interface and provide input to NS in areas of operations that may be different from the safety analysis basis for determination of any possible USQs. 

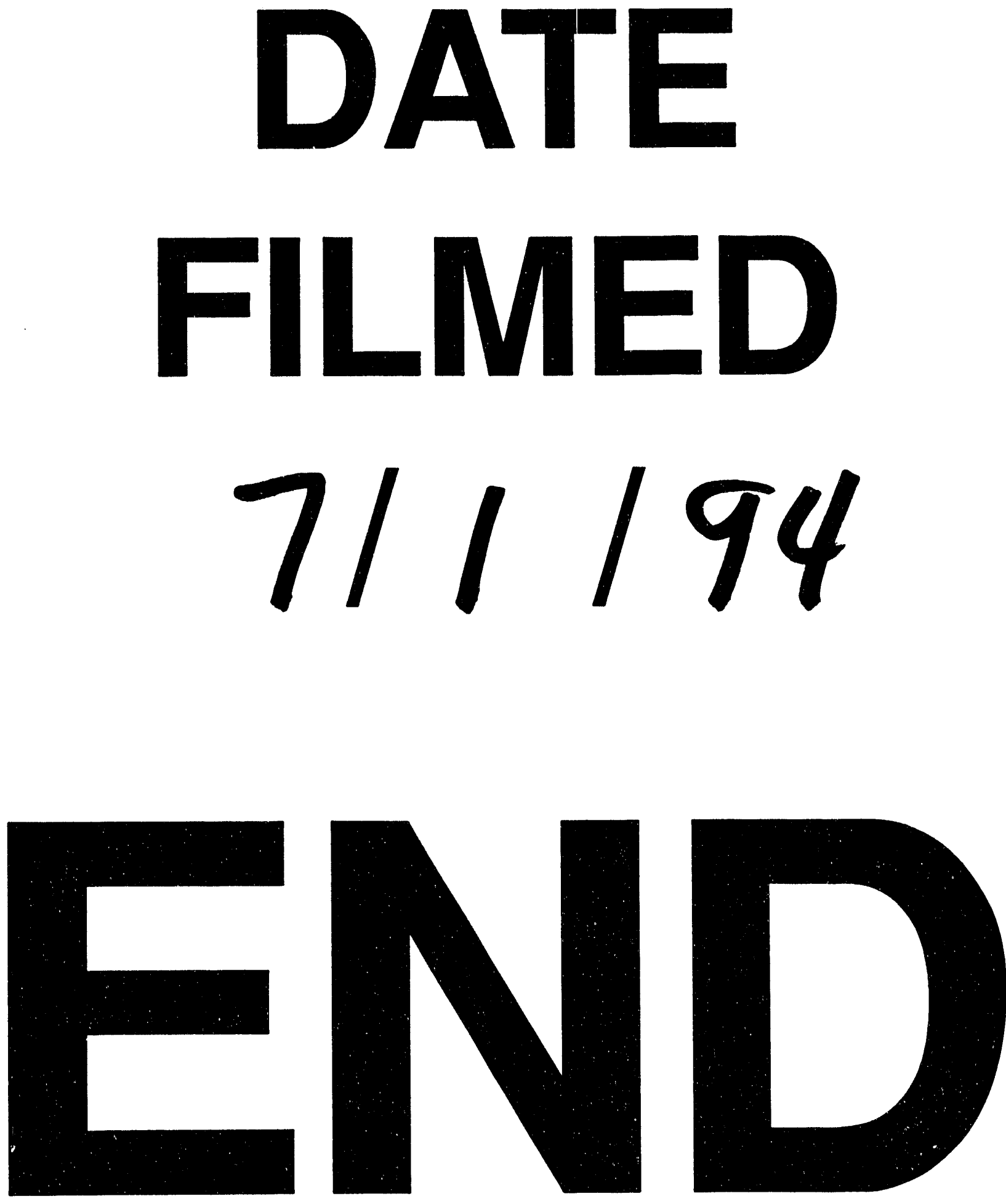
